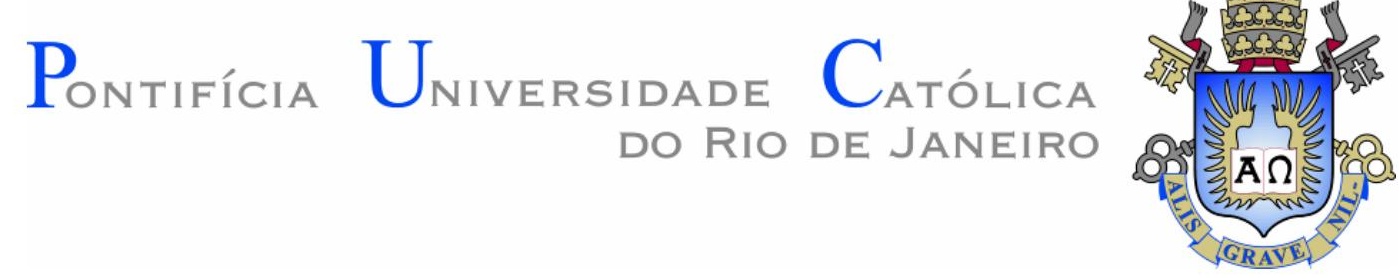

\title{
Ellen Gonzalez
}

Food Design:

Um olhar sistêmico sobre

o papel do chef de cozinha

Dissertação apresentada como requisito parcial para obtenção do grau de Mestre pelo Programa de Pós-graduação em Design da PUC-Rio

Prof. Alfredo Jefferson de Oliveira Orientador

Departamento de Artes e Design - PUC-Rio

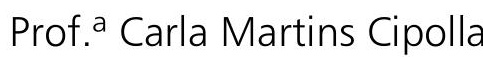
Coorientadora Universidade Federal do Rio de Janeiro - UFRJ 


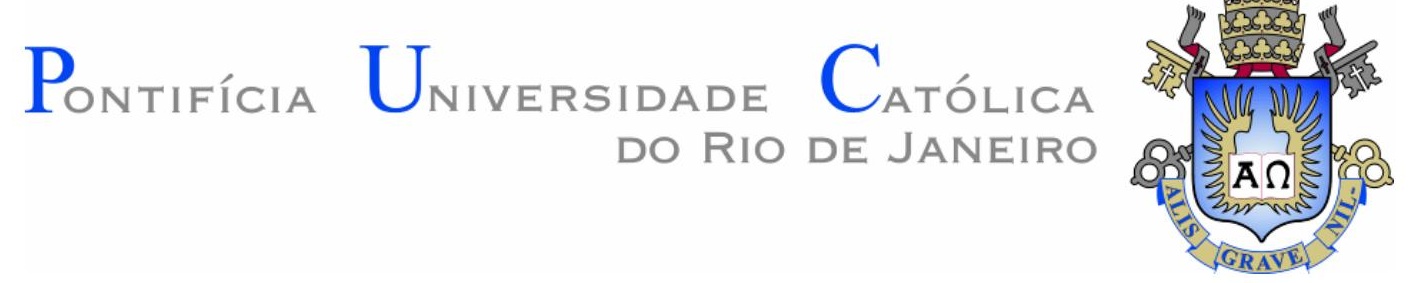

Ellen Gonzalez

Food Design:

Um olhar sistêmico sobre

o papel do chef de cozinha

Dissertação apresentada como requisito parcial para obtenção do grau de Mestre pelo Programa de Pós-graduação em Design da PUC-Rio. Aprovada pela Comissão Examinadora abaixo.

Prof. Alfredo Jefferson de Oliveira Orientador

Departamento de Artes e Design - PUC-Rio

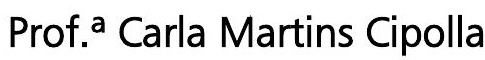

Coorientadora

Universidade Federal do Rio de Janeiro - UFRJ

Maria Manuela Rupp Quaresma

Departamento de Artes e Design - PUC-Rio

Aguinaldo dos Santos

Universidade Federal do Paraná - UFPR 
Todos os direitos reservados. É proibida a reprodução total ou parcial do trabalho sem autorização da universidade, do autor e do orientador.

Ellen Silvia Lopes Gonzalez Aguilera Graduou-se em Arquitetura e Urbanismo pela UFPR (Universidade Federal do Paraná) em 2005. Concluiu o Grand Diplôme de Cuisine a Pâtisserie no Le Cordon Bleu Paris em 2010. É chef de cozinha desde 2015, sócia proprietária da me. confeitaria artesanal, professora e Diretora Acadêmica do Le Cordon Bleu Rio de Janeiro.

Aguilera, Ellen Silvia Lopes Gonzalez

Food design : um olhar sistêmico sobre o papel do chef de cozinha / Ellen Silvia Lopes Gonzalez Aguilera ; orientador: Alfredo Jefferson de Oliveira ; co-orientador: Carla Martins Cipolla. - 2021.

166 f. : il. color. ; $30 \mathrm{~cm}$

Dissertação (mestrado)-Pontifícia Universidade Católica do Rio de Janeiro, Departamento de Artes e Design, 2021.

Inclui bibliografia

1. Artes e Design - Teses. 2. Food design. 3. Comida. 4. Chef de cozinha. 5. Consumo consciente. 6. Cadeias curtas de produção e consumo de alimentos. I. Oliveira, Alfredo Jefferson de. 


\section{Agradecimentos}

Escrever essa dissertação, de alguma maneira, presta uma homenagem aos colegas de cozinha, chefs e grandes amigos, que fazem de sua profissão um instrumento de transformação social, de afirmação, e de representação. Há que se honrar a comida, e a todos que trabalham com ela com o carinho, o respeito e o cuidado que o alimento merece. Quem tem amigos na cozinha, tem tudo: Betim, Bruno e Alexandre, Carol, Duda, Flavinha, Lucio, Ludi, Mari, Matheus, Rafa, Roberta, Selene e Dom, Teresa, Thiago e Bruno.

A jornada do mestrado certamente não teria acontecido sem o incentivo, apoio e compreensão de Fabio Lopez, que permitiu que a vida continuasse seu curso enquanto eu me dedicava a tudo que aconteceu nesse período. Obrigada pelo carinho, cuidado e pela presença constantes.

Nada teria começado sem o estímulo e torcida do casal Portas, que acompanhou cada etapa com tanto entusiasmo e generosidade. E Daniel Neves, que colocou a cereja no bolo com talento.

Aos meus orientadores Carla e Alfredo, sem os quais a caminhada não teria sido tão enriquecedora, cheia de sorrisos e aprendizado. Não houve um dia nesses dois anos em que eu não tivesse a certeza de ter feito a escolha certa. Obrigada por tanto!

Aos meus colegas de turma, professores e funcionários da PUC-Rio, UFRRJ e UFRJ que contribuíram, cada um à sua medida, para meu aprendizado.

O presente trabalho foi realizado com apoio da Coordenação de Aperfeiçoamento de Pessoal de Nível Superior - Brasil (CAPES) - Código de Financiamento 001. 


\section{Resumo}

Gonzalez, Ellen; Oliveira, Alfredo Jefferson de. Food Design: Um olhar sistêmico sobre o papel do chef de cozinha. Rio de Janeiro, 2021. 166p. Dissertação de Mestrado - Departamento de Artes e Design, Pontifícia Universidade Católica do Rio de Janeiro.

Este estudo aborda o Food Design como uma lente para o Design Sistêmico e de Serviço em gastronomia, mais especificamente, para instrumentar chefs de restaurantes no Rio de Janeiro a revisar e modificar relacionamentos em cadeias curtas de produção e consumo de alimentos. Esse conjunto de ações objetiva influenciar e estimular a consciência do consumidor, mudando assim o modo como os alimentos são percebidos e consumidos e a relação entre o usuário final e o produtor. A Design Science Research foi aplicada como espinha dorsal metodológica para desenvolver uma solução (artefato) que melhore o fluxo do campo à mesa no Rio de Janeiro, conscientização do consumidor e cadeias agrícolas locais. Para complementar, os métodos de Pesquisa-ação Participante, Food Design, Design Thinking e Design de Serviço foram também adotados, em um processo imersivo e empático na questão em análise, aprimorada neste estudo pela vivência pessoal da autora, experiente chef de cozinha. O estudo aborda os desafios de uma cadeia de alimentos mais saudável e sustentável, benefícios e obstáculos enfrentados pelos chefs que trabalham com agricultores familiares e pequenos produtores. A pesquisa se debruça sobre barreiras existentes e busca entender como o design pode contribuir na superação desses obstáculos, na interação com os prestadores de serviços de alimentação e na promoção do consumo consciente com sistemas e serviços para chefs. Este trabalho é fortemente apoiado pelo conhecimento empírico dos chefs locais selecionados, com iniciativa relevante para encurtar a cadeia, uma vez que a referência escrita sobre o assunto é um tanto escassa e quase nenhum estudo de Design se concentra no restaurante como sistema alimentar ou seus impactos. Outro sustentáculo da pesquisa se apresenta na experiência didática de Design de Serviço para alimentação em um exercício com alunos da Graduação sobre o tema. Os resultados levantados por esta pesquisa fornecem insights e anteveem a possibilidade de replicação, tendo explorado principalmente questões logísticas, culturais, e as facetas diretas de inovação social que ela contém.

\section{Palavras-chave:}

Food Design, comida, chef de cozinha, consumo consciente; cadeias curtas de produção e consumo de alimentos. 


\section{Abstract}

Gonzalez, Ellen; Oliveira, Alfredo Jefferson de. Food Design: a systemic eye on the role of the chef de cuisine. Rio de Janeiro, 2021. 166p. Dissertação de Mestrado - Departamento de Artes e Design, Pontifícia Universidade Católica do Rio de Janeiro.

This study approaches Food Design as a lens for the Systemic and Service Design in gastronomy, more specifically, to provide tools for chefs in Rio de Janeiro to review and modify relationships in short food supply chains; wherewith influencing and encouraging conscious consumption, thus changing the way food is perceived and consumed and the relationship between the end user and the producer. Design Science Research was adopted as a methodological backbone to develop a solution (artifact) that improves the flow from farm to table in Rio de Janeiro, consumer awareness and local agricultural chains. Participatory Action Research, Food Design, Design Thinking and Service Design methodologies were also adopted, in an immersive and empathetic process in the question under analysis, which was enhanced in this study by the personal experience of the author, versed restaurant chef. The study approaches the challenges of a healthier and more sustainable food supply chain, benefits and obstacles faced by chefs who work with family farmers and small-scale producers. This has been done by surveying existing barriers, understanding how to overcome these obstacles with systems and services for chefs, who rely on a network of small farmers to surpass the difficulties of interacting with food industry service providers and promoting conscious consumption. This work is strongly supported by the empirical knowledge of the selected local chefs with relevant initiative in bypassing this chain, since written reference on the subject is somewhat scarce, and hardly any Design study has focused on the restaurant as a food system or its impacts. Another support of the research is presented in the didactic experience of Service Design for food in an exercise with undergraduate students on the theme. The results raised by this research provide insights and foresee the possibility of replication, having explored logistics and cultural issues mostly, and the direct social innovation facets it contains.

\section{Keywords:}

Food Design, food, chef de cuisine, conscious consumption, short food supply chain. 


\section{Lista de Figuras}

Figura 01 . Mapa contextual do Food Design (Reissig, 2019).

Figura 03 . Food Design Manifesto Map, Su Hyuyn Park (in Vogelzang, 2018).

Figura 04 . Linha do tempo do Food Design (Reissig, 2019).

Figura 05 . Subcategorias de Food Design segundo Zampollo (2016b)....... 36

Figura 06. Exibição interativa "Eat Love Budapest", de Marije Vogelzang

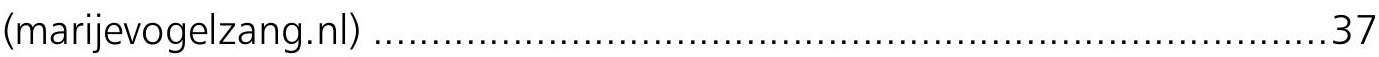

Figura 09 . Livro "The in vitro meat cookbook" (2014)........................... 38

Figura 10. Os quatro pilares do Food Design (Zampollo, 2017)................ 38

Figura 11 . O sistema alimentar (Departamento de Agricultura dos Estados Unidos, 2019) ....................................................................... 40

Figura 12. ODS e sua relação com Comida e Agricultura (FAO, 2020) ......47

Figura 13. A contribuição do sistema alimentar para o consumo de energia e emissões (Global Food Policy Report, 2016)........................................ 51

Figura 14. "Monotonia na dieta brasileira" (O Joio e o Trigo, 2020)...........53

Figura 15 . Sistemas alimentares (Foodsystems, 2020) ......................... 56

Figura 16 . Sistemas Alimentares (Haddad et al., 2016).........................58

Figura 17: Produção alimentar da agricultura familiar no Brasil (Secretaria Especial de Agricultura Familiar e Desenvolvimento Agrário)

Figura 18 . Perspectivas agrícolas 2010 (Climate Change, Agriculture and Food Security)

Figura 19. Perspectivas agrícolas 2030 (Climate Change, Agriculture and Food Security).

Figura 20 . Perspectivas agrícolas 2050 (Climate Change, Agriculture and Food Security).

Figura 21 . Food Design Thinking Methodology. (Zampollo, 2014)............ 90

Figura 22. Mapa de autores. ........................................................... 93

Figura 23. Mapa de atores. .............................................................. 95

Figura 24 . Questionário aplicado para produtores e chefs...................... 97

Figura 25. Storyboard "Um dia na vida" 2020.................................... 99

Figura 27 . Jornada do cozinheiro para o jantar harmonizado. ................ 100

Figura 28 . Pratos dos jantares realizados ...................................... 101

Figura 29. Diário do prato (Raphael Flaksberg, JBF)........................... 102

Figura 30 . Síntese de princípios e práticas. ...................................... 105

Figura 31 . Personas.......................................................... 109

Figura 30 . Dados mais relevantes sobre os consumidores entrevistados ...109

Figura 32 . Perfil de consumidores entrevistados............................. 110

Figura 33 . Perfil de consumidores comerciais (Junta Local, 2020)............ 111

Figura 34 . Análise e Síntese Produtores ....................................... 113

Figura 35 . Análise e Síntese Chefs .................................................. 115

Figura 36 . Análise e Síntese Consumidores ...................................... 115 
Figura 37 . Síntese do Desafio de Food Design ……...............................117

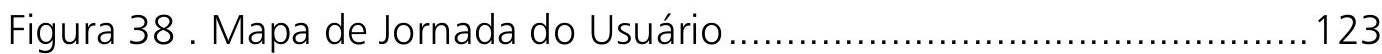

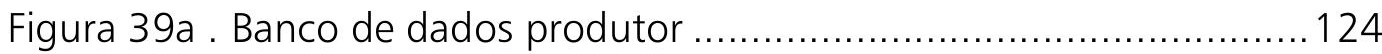

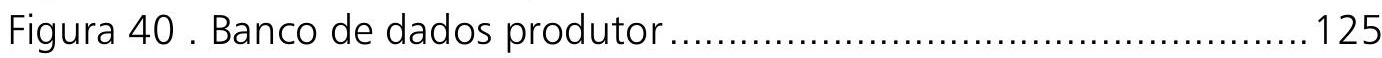

Figura 41 . Banco de dados cozinheiro/restaurante...............................126

Figura 42b. Banco de dados cozinheiro/restaurante............................. 127

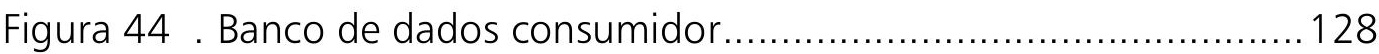

Figura 45. Representação visual e paleta de cores Planta .......................129

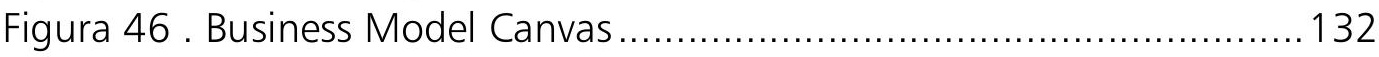

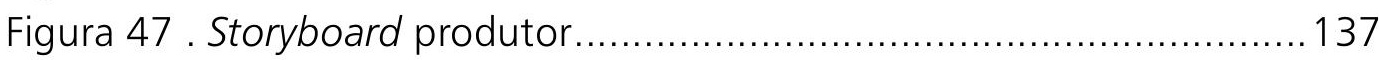

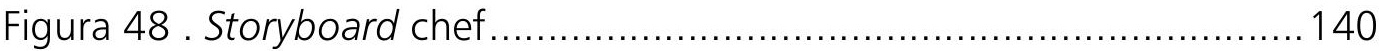

Figura 51. Planta, aplicativo mobile Produtor ..................................... 144

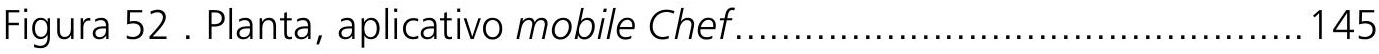

Figura 53 . Planta, aplicativo mobile Consumidor .................................. 146

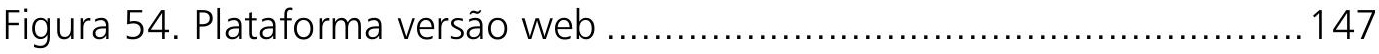

Figura 55. Aplicativo em momentos de interação: consumidor e restaurante.

Figura 56 . Modelo de entreposto. Fonte: A Colheita............................ 147

Figura 55. Feira de pequenos produtores. Fonte: Samuel Antonini.......... 148

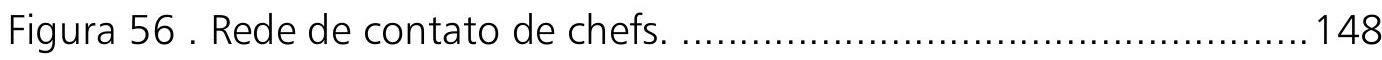

Figura 57 . EFood Lisboa 2019 ...................................................... 149

Figura 58 . Serviço desenvolvido pelos alunos de Graduação, Design, UFRJ. 150

Figura 59. SLOW análise e adaptação das propostas de Ballantyne-Brodie (2017).

\section{Anexos}

Anexo 01 . Mapa de literatura da pesquisa

Anexo 02 . Termo de Consentimento livre e esclarecido entrevistados

Anexo 03 . Termo de Consentimento alunos graduação UFRJ

Anexo 04 . Questionário Consumidor

Anexo 05 . Rotina dos entrevistados

Anexo 06 . Cartões de Insight

Anexo 07 . Carta de Valores da Junta Local

Anexo 08 . Sessões Generativas . painel de especialistas

Anexo 09 . Jornada do Usuário 


\section{Sumário}

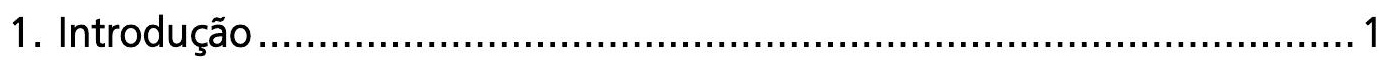

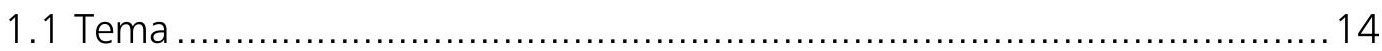

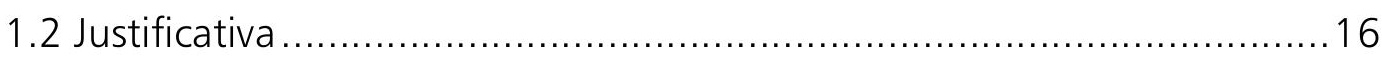

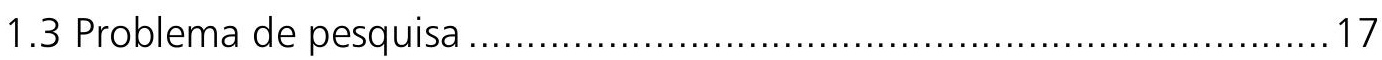

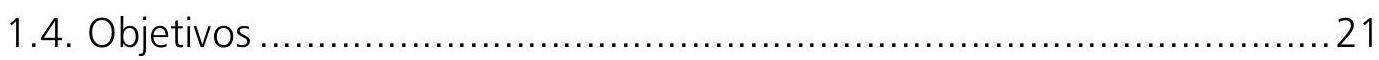

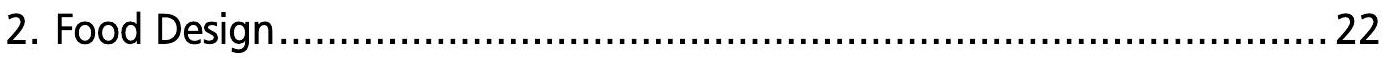

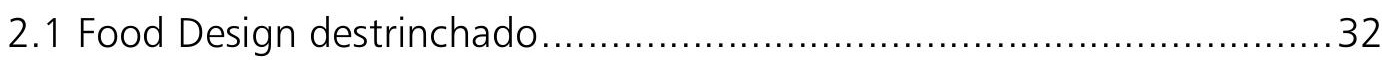

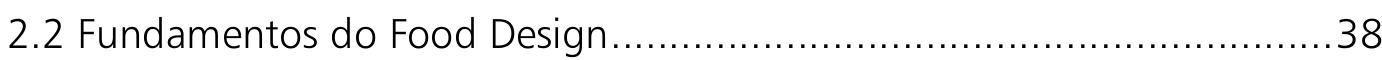

3. As cadeias curtas de produção e consumo: do produtor ao consumidor pelas mãos do chef de cozinha......................................................... 55

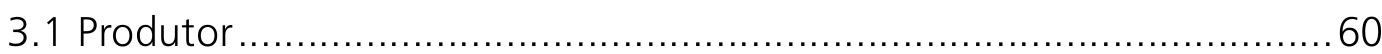

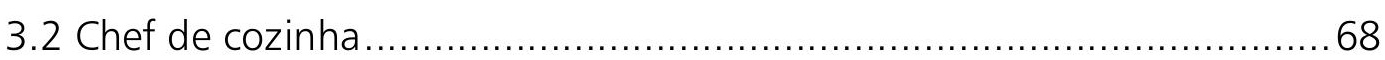

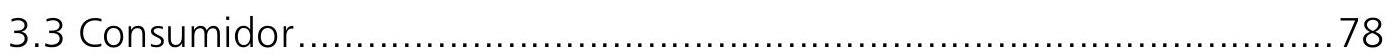

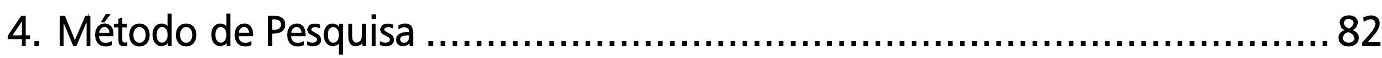

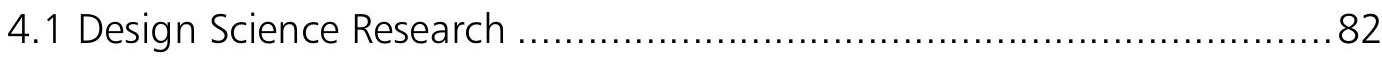

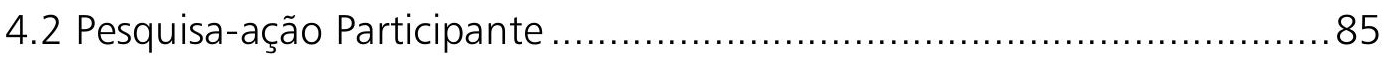

4.3 Design Thinking, Design de Serviço e Food Design Thinking..................86

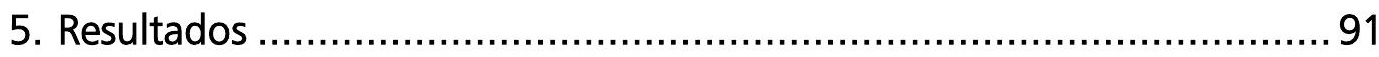

5.1 Imersão Preliminar e Imersão em Profundidade ...................................91

5.1.1 Imersão Preliminar . Pesquisa Desk ................................................ 92

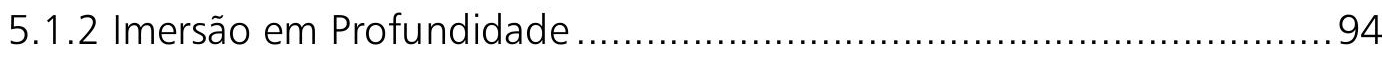

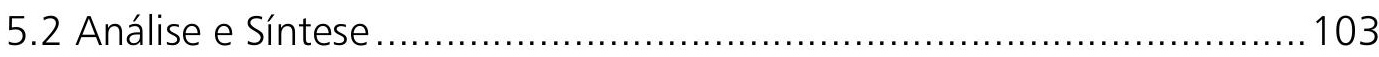

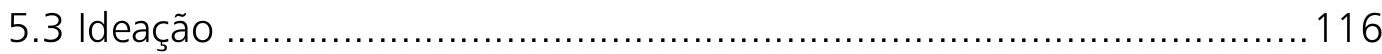

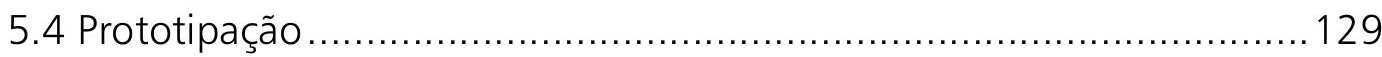

5.5 Design de Serviço e o pensamento crítico sobre a alimentação por futuros

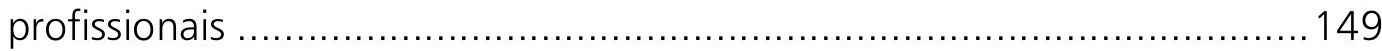

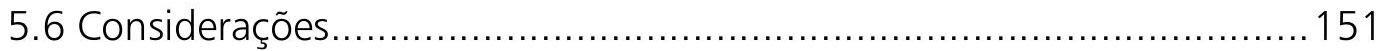

6. Uma reflexão sobre Comer, Design e o Food Design .......................... 154

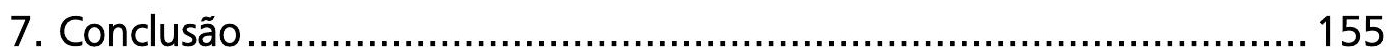

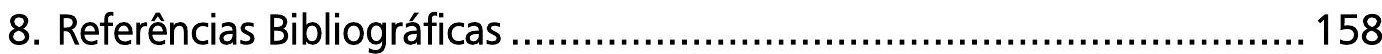


"Nós estamos indissoluvelmente ligados à nossa comida e, ao fazer a pergunta 'como vamos nos alimentar?', você também está perguntando como vamos viver e compartilhar e como equilibraremos nossa existência com a natureza. Comer é um ato ecológico e político e não podemos nos afastar. Você tem um poder incrível pelo fato de que você come." ${ }^{1}$

(Steel, 2019).

1 "We are inextricably tied to our food and in asking the question 'how are we going to feed ourselves?', you are also asking the question of how we are going to live and share and how we are going to balance our existence with nature. Eating is an ecological and political act and we can't step away from it. You have incredible power through the fact that you eat." 


\section{Introdução}

"A comida tem o poder de trazer todas as questões à mesa." 2 (Willett, Rockström, Loken et al., 2019).

Comida.

A indústria da alimentação é responsável por movimentar um terço da economia mundial, consumir $70 \%$ da água potável do planeta, cerca de $48 \%$ de ocupação do solo e quase $1 / 3$ do total de emissões de gás de efeito estufa, desmatamento, redução da biodiversidade. Também está ligada diretamente a números expressivos de mortalidade humana, seja por excesso ou carência de alimentos (Ivanova et al., 2015).

O desafio de alimentar 10 bilhões de pessoas em 2050 traz consigo a necessidade de aumento na produção e mudanças no consumo de alimentos. Junto a isso, carrega outras questões ligadas à comida, que devem se intensificar nas próximas décadas, como sustentabilidade, agrobiodiversidade, produção em massa, poluição, sobreuso dos recursos naturais, ética e bem-estar animal e humano, soberania alimentar ${ }^{3}$, segurança alimentar ${ }^{4}$, qualidade versus quantidade, além de questões políticas, culturais e sociais (Menezes \& Oliveira, 2019). O relatório EATLancet (Willett, Rockström, Loken et al., 2019) traz a urgência de se transformar o sistema alimentar como forma de garantir que a população mundial esteja adequadamente nutrida, e de preservação do meio ambiente.

De acordo com o Painel Global da FAO (2018), é hora de pensar além da agricultura e considerar todos os processos e atividades envolvidos na cadeia de produção de alimentos, como processamento, armazenamento, transporte, comércio, transformação e varejo.

Segundo a FAO (2106), enfrentar o revés da alimentação e da agricultura têm sido tarefa de pequenos produtores: a maior parte dos cultivos agrícolas para

2 "Food has the power to bring all parties to the table."

3 Soberania alimentar é um conceito amplo, que se baseia na premissa de garantir a segurança alimentar como uma política pública, em dar suporte a modos de vida sustentáveis, promover qualidade de vida a quem produz alimentos, fomentar os sistemas alimentares locais, promover a propagação do conhecimento e técnicas relacionados aos sistemas alimentares e, por fim, trabalhar em acordo com a natureza (FAO, 2013).

4 Segurança alimentar é quando toda uma população tem pleno acesso à comida que seja suficiente, segura e nutritiva, que seja culturalmente reconhecida, e que seja adequada para sustentar uma vida ativa e saudável (FAO, 2013). 
consumo humano direto é produzida pela agricultura familiar. Ela ocupa menos de um quarto da superfície cultivável do planeta, provendo surpreendentes $70 \%$ dos alimentos para consumo direto contra 30\% do agronegócio, que abrange $75 \%$ das terras agrícolas. Igualmente alarmante é o fato de, na última década, as culturas para a produção de biocombustíveis cresceram mais rapidamente do que as culturas para a produção de alimentos.

Outra diferença notável nos sistemas agrícolas são os papéis desempenhados por estruturas contrastantes: pequenos produtores performam funções econômicas, sociais, culturais, ambientais e reprodutivas e são essenciais para manter a agrobiodiversidade, territórios, paisagens, patrimônio cultural e comunidades, dentro de um sistema alimentar racional e socialmente justo. Esses resultados vão muito além do máximo lucro, se debruçando também sobre questões sociais, culturais e ecológicas (FAO, 2018). São justamente essas pessoas, a espinha dorsal do sistema produtivo, que paradoxalmente mais sofrem com o atual sistema, enquanto as grandes empresas maximizam seus lucros.

A pergunta, tantas vezes banalizada, "o que temos para o jantar?" pode trazer uma infinidade de discussões complexas à tona, envolvendo diretamente cultura e identidade, mas também políticas, econômicas e sociais. As escolhas cotidianas refletem a opção por perpetuar ou quebrar modelos de consumo, colocando o consumidor no papel de protagonista na tomada de decisão (Nature Hub, 2018).

De acordo com declarações feitas no Painel Global de Agricultura e Sistemas Alimentares para Nutrição da FAO (2016) o consumidor, uma vez imbuído de conhecimento e capacitação, exigirá melhores alimentos, e essa nova abordagem fará com que o sistema de fornecimento de alimentos proveja comida de qualidade para todos. O impacto nos meios de produção e comércio agrícolas afetam diretamente o meio ambiente e a saúde pública. Para acompanhar, as empresas terão que mudar ou abordar certas políticas para se enquadrar e se posicionar no mercado.

As cadeias alimentares que abastecem os consumidores estão crescendo, com o comércio global aumentando a distância entre produção e consumo. Há uma falsa impressão de que com isso, cresce similarmente a diversidade de alimentos disponíveis para os consumidores. O valor e a potência nos sistemas alimentares todas as pessoas e atividades relacionadas ao cultivo, produção, transporte, abastecimento e consumo de alimentos - estão mudando para o meio dessas cadeias alimentares, com produtos agrícolas se tornando ingredientes para produtos 
processados (FAO, 2012; Sethi, 2020). Para reverter esse mecanismo, os indivíduos devem ser estimulados a comer alimentos mais frescos e sazonais, seja cozinhando suas próprias refeições, recebendo em casa, ou comendo-os em locais que ofereçam o alimento menos processado possível.

A maneira como o alimento é tratado e oferecido mudou sensivelmente, e até certo ponto, o mesmo aconteceu com o fornecimento. Ao estabelecer contato direto com os agricultores, o chef atua na prevenção de intermediários e das armadilhas do mercado, encurtando a cadeia de suprimentos, um mecanismo de transformação econômica, cultural e social.

As cadeias curtas de produção e consumo de alimentos (CCCA) e o consumo consciente estão profundamente ligados ao tripé da sustentabilidade. Esses tópicos do sistema alimentar tratam diretamente as questões econômicas, sociais e ambientais, sendo listados na agenda da ONU para os Objetivos de Desenvolvimento Sustentável (ONU, 2015) e no Acordo de Paris (2016). Os sistemas alimentares têm o potencial de nutrir a saúde humana e apoiar a sustentabilidade ambiental. No entanto, eles estão ameaçando a ambos. Proporcionar uma população global crescente com dietas saudáveis a partir de sistemas alimentares sustentáveis é um desafio imediato.

As CCCAs se conectam diretamente a essas questões. Consistindo em uma sequência de atores e ações, elas asseguram a presença do menor número possível de intermediários e de um sistema de negociação mais justo e mais transparente, a todos os envolvidos, desde a plantação até ao consumidor final. Desta cadeia, três personagens principais serão tratados neste estudo. As pontas, mais distantes do que nunca, são o produtor e o consumidor final. Eles habitam, às vezes, mundos virtualmente separados, e ainda assim, tangenciam-se cada vez que o serviço é trocado. Entre os múltiplos atores possíveis nesse sistema, essa dissertação lança o olhar do design sistêmico e sustentável sobre a cadeia produtiva de alimentos com foco no chef de cozinha, responsável por importantes pontos de contato entre os dois extremos.

O ator central, o chef de cozinha de restaurante, tem as habilidades e a capacidade de discernir e modificar alimentos, podendo afetar a demanda final. O objetivo é entender como os chefs de cozinha podem melhorar o fluxo da produção agrícola para a mesa do consumidor, atingir e influenciar o maior número possível de consumidores finais, mudando assim a forma como os alimentos são percebidos e consumidos; impactando as relações sociais e econômicas estabelecidas entre os clientes finais e o produtor. 
O projeto MAD, um paralelo do G-20 para a gastronomia mundial que une a comunidade de cozinheiros de todo o mundo desde 2011, conscientizando sobre como o sistema alimentar afeta diretamente o meio ambiente global e sua população, propõem-se a:

"[...] transformar nosso sistema alimentar, oferecendo aos chefs e donos de restaurantes as habilidades, a comunidade, o tempo e o espaço para criar uma mudança real e sustentável em seus restaurantes, em suas comunidades e em todo o mundo" (MAD, 2017).

Durante o Simpósio MAD 2017, Carlo Petrini, fundador do movimento Slow Food, falou sobre a importância do sistema alimentar na saúde geral do planeta, seja o meio ambiente ou o seu povo, quando ele disse "não é um sistema alimentar, é um sistema criminoso". Petrini foi enfático quanto a isso, ao afirmar que a cozinha do amanhã deve ir contra esse sistema; deve unir chefs de cozinha, produtores e consumidores, e colocar os consumidores no papel de coprodutores, partilhando a responsabilidade (Petrini, 2017).

O olhar do designer sobre o sistema alimentar pode instrumentar os atores envolvidos, colocando o chef como protagonista deste sistema de compras e transformação de alimentos, para resolver suas demandas diárias de se conectar com uma variedade de fornecedores, elaborar e divulgar cardápios e produtos, e com isso aumentar o interesse do cliente não apenas pela comida preparada, mas também pela maneira que ela chega à mesa.

\subsection{Tema}

"Food Design é qualquer ação do design aplicado a qualquer coisa relacionada à comida ou ao comer." ${ }^{5}$ (Zampollo, 2016a).

Food Design: Sistemas Alimentares Sustentáveis.

As problemáticas atuais do Food Design, que será detalhado no Capítulo 2, aludem à inovação e preceitos de sustentabilidade ligados aos processos e interfaces de contato direto e adjacentes à comida; à ausência de metodologias consolidadas para estudo e prática profissional do food designer; e à necessidade de se trabalhar de maneira interdisciplinar, para que se possa compreender todas as camadas e conexões de um sistema tão amplo quanto específico (ReLAFD, 2020). Os motes

5 "Food Design is any act of design applied to anything food or eating related." 
abordados podem incluir, mas não se restringem à: senso, significado e escala. Estes podem ser tangibilizados como produtos, processos, ambientes/entornos, materiais, práticas, sistemas, tecnologia e experiências, passíveis de projeção. O papel do designer é justamente o de integrar todos os argumentos, atores e cenários (Reissig, 2019).

O campo do design imaterial, com foco na experiência, mais do que a simples venda de produtos palpáveis, é capaz de transformar as relações, valorizar as origens, fidelizar relacionamentos, e transformar o consumidor em um participante ativo na cadeia produtiva. Ezio Manzini (2010) traz o design como um processo de integração social, e fala sobre a participação efetiva, onde o papel de usuário passa a ser o de participante, causando uma mudança social. Essa prática favorece a geração de soluções apropriadas, que estarão sempre em consonância com os anseios e necessidades da população envolvida.

O modelo simples e de origens remotas de comercialização de alimentos, com venda direta do produtor ao consumidor final, voltou a chamar atenção de pesquisadores no mundo todo, e é curiosamente incipiente no Brasil, onde até pouco tempo não se dava muito enfoque ou valor à economia distribuída, calcada nas relações entre produtores rurais de pequena escala e o mercado. Esse modelo, tratado neste trabalho como CCCA, quando sujeito à perspectiva analítica e projetual do design, possibilita questionar e modificar os padrões de produção e consumo dominantes (agronegócio, exploração insustentável dos ecossistemas, uso indiscriminado de químicos), conectando produtores e consumidores finais, e encurtando as distâncias físicas, sociais, culturais e econômicas entre eles. O resultado dessa dinâmica é uma cadeia mais humanizada, fruto de um processo de design sistêmico e sustentável.

Abordagens de design análogas às do Design Thinking e de Serviço, a serem explanadas no capítulo 4.2, requerem um processo empático na questão em análise (Vianna et al., 2012). A experiência imersiva foi fortalecida neste estudo pela vivência pessoal da autora, chef de cozinha e membro de uma plataforma de alimentação boa, justa e local. Essa perspectiva representa um olhar muito particular sobre as questões levantadas para esse exercício, e pode trazer contribuições relevantes tanto à prática profissional (do design e da gastronomia) quanto à academia.

É importante entender o dia a dia de um chef de cozinha, que envolve obstáculos gerenciais e criativos, sendo a pessoa responsável por toda a comida e equipe de produção de um restaurante. A elaboração de um menu envolve uma 
série de processos de tomada de decisão, a partir da origem, qualidade e valor do produto escolhido, e da maneira como os alimentos serão processados, apresentados e, finalmente, vendidos ao consumidor. Esse profissional deve, outrossim, considerar as limitações técnicas do espaço e da brigada, o desperdício de alimentos, a aceitação do cliente e as condições de viabilidade financeira do restaurante.

"[...] o Design não é orientado em primeiro lugar para a criação de novos conhecimentos, mas sim, às práticas da vida cotidiana. [...] não em termos de eficiência física como acontece nas engenharias, mas sim, em termos de comportamento inserido na dinâmica cultural e social." (Bonsiepe, 2018).

\subsection{Justificativa}

A temática do Food Design se faz presente em algo absolutamente básico, cotidiano e íntimo, e que nem sempre é tratado com o cuidado merecido. Seja na questão da saúde, das relações, do prazer, é comum que os processos que trazem a comida de sua origem até o ato do consumo sejam relegados. Colocar esse assunto, literalmente, sobre a mesa, questionar de onde veio esse alimento, qual seu trajeto, quem o manuseou, como ele entra e o que causa no organismo, é o primeiro passo (ReLAFD, 2020). Para a Rede Latino-americana de Food Design, o pensamento e planejamento críticos e propositivos, que visam melhorar o relacionamento com a comida em todos os sentidos e instâncias, estão dentro do escopo de Food Design (Reissig, 2019). A figura 01 a seguir destaca as cinco etapas do ciclo do alimento, da produção ao consumo, enfatizando que se pode ir direto da produção ao consumo, pular uma ou outra etapa, mas que de maneira geral, é o caminho percorrido pela comida da maior parte da população.

A produção não sustentável de alimentos representa um risco global para as pessoas e para o planeta. Atualmente mais de 820 milhões de pessoas não têm comida suficiente, enquanto aproximadamente um terço dos alimentos produzidos no planeta é perdido ou desperdiçado. Além disso, como os sistemas alimentares são um dos principais impulsionadores de problemas de saúde e degradação ambiental, os esforços globais são urgentemente necessários para transformar coletivamente as dietas e a produção de alimentos (Willett, Rockström, Loken et al., 2019). 


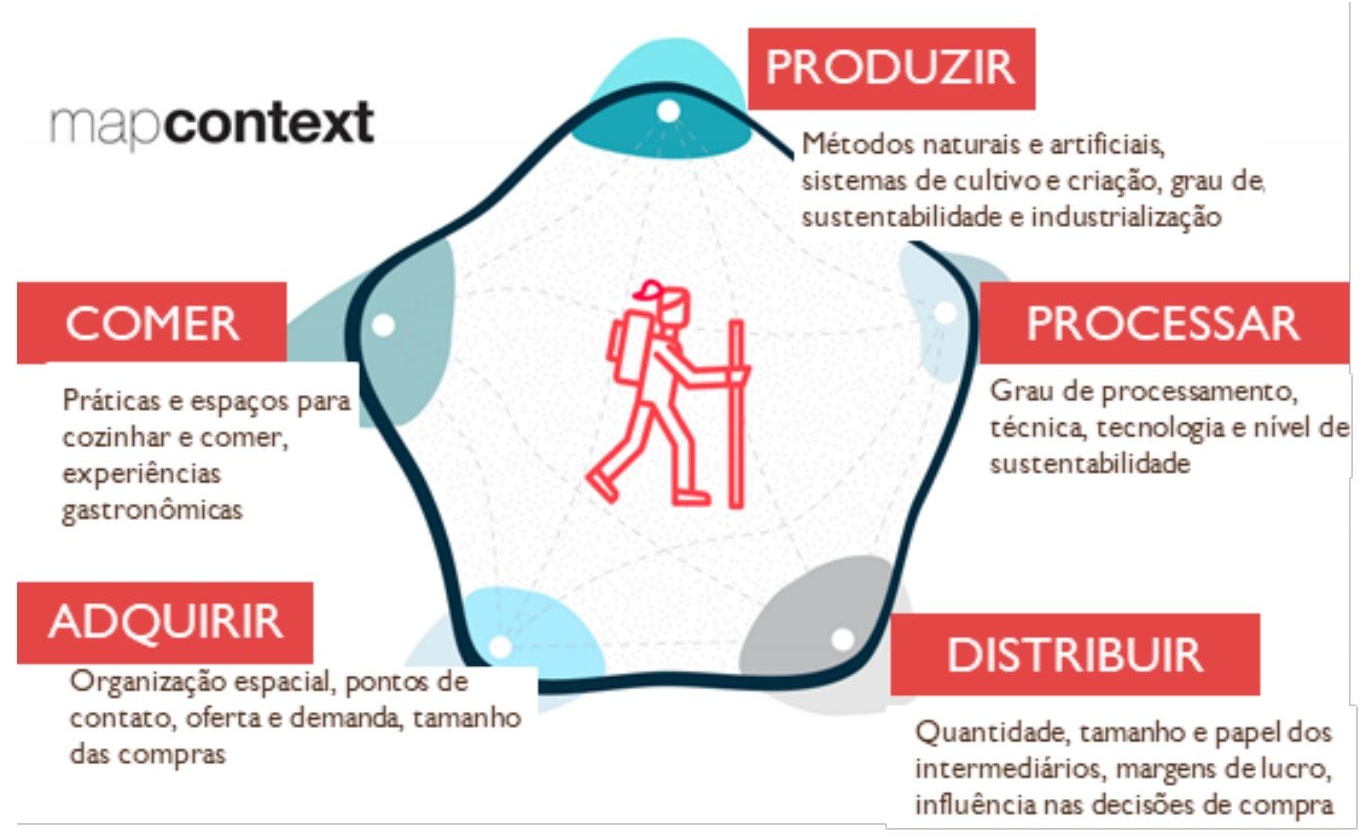

Figura 01 . Mapa contextual do Food Design (Reissig, 2019).

Os métodos produtivos em escala industrial causam enormes impactos, ameaçando os ecossistemas locais e a estabilidade do sistema terrestre. Esse cenário, aliado ao crescimento populacional projetado para cerca de 10 bilhões até 2050, nos colocará no limite da capacidade na Terra. É preciso agir em ambas as pontas das cadeias de produção e na conscientização do consumo dos alimentos.

A prática do design envolve (e desenvolve) habilidades de empoderar tanto as comunidades locais quanto órgãos governamentais e capacitá-los a se desenvolver, inovar e dar resiliência aos sistemas alimentares locais, como mostram Manzini (2008, 2010, 2015) e Meroni (2008, 2014).

Em 1984, Papanek já previa a atribuição socioambiental do designer, e em seu livro "Design for the Real World: Human Ecology and Social Change" ele estabelece como desafios para a profissão a gestão multidisciplinar na produção de soluções de design em harmonia com a natureza. Essa perspectiva aponta como fundamentos éticos do design a premissa de estabelecer relações e de projetar não só para clientes, mas considerando o meio ambiente e seus recursos (Ballantyne-Brodie, 2017).

\subsection{Problema de pesquisa}

Orientada pelas questões sociais e ambientais contemporâneas, apresentadas e a conectividade interpessoal possibilitada pela tecnologia, a disciplina do Design trata de maneira sistêmica e centrada no usuário tais preocupações, e abre espaço 
para resultantes imateriais de seu processo produtivo (Manzini, 2006). Esse processo é dado colaborativamente, com diferentes atores e profissionais de diversos campos do saber, resultando em sistemas de produto-serviço (PSS), com intuito de gerar inovações sustentáveis. O designer passa a atuar como articulador, coordenador de equipes multidisciplinares, projetando cenários para o futuro, ajudando a identificar as demandas e projetando soluções para os problemas (Manzini, 2016; Meroni، 2009).

A abordagem do Design focado na sustentabilidade passa, obrigatoriamente, pela desconstrução dos sistemas e padrões de produção e consumo, e pela reconstrução desses modelos. Esse campo do design é muito rico em oportunidades para inovação, principalmente quando vislumbrada a possibilidade de ir além do produto, contemplando a "satisfação final do usuário, respeitando os limites de resiliência ambiental e as demandas sociais do entorno, ao invés da mera oferta de artefatos físicos" (Vezzoli, 2018).

O Design sustentável, com foco nos sistemas alimentares, em particular,

"constitui da pluralidade em torno da alimentação, seu propósito no mundo está sendo amadurecido, mas sabemos que sua missão principal é melhorar a relação existente entre o ser humano e o alimento. O Food Design é a disciplina que busca transformar a alimentação pelo Design, bem como identificar uma inovação da alimentação que sirva para todos." (ReLAFD, 2020).

Trabalhar em rede é uma solução recorrentemente apontada pelos profissionais do Design e da alimentação, e cabe aos designers a condução desses atores, a proposição de metodologias, auxiliando na construção das soluções.

Sob esse holofote, o designer tem a capacidade de tratar das questões alimentares, cotidianas e muitas vezes banalizadas, de maneira a redesenhar o dia a dia como algo sistêmico, impactando diretamente nas relações sociais, econômica e política. Criar formas de convívio possibilita também retomar e reconstruir relações humanas, baseadas mais nas necessidades ambientais e sociais que nas econômicas. Este projeto trata justamente desse assunto tão presente quanto relegado, que é a produção e o consumo de alimentos, e os incontáveis, e muitas vezes desnecessários, processos existentes entre um e outro. Nesse sentido, o design pode dar suporte ao chef de cozinha, para que esse profissional tenha um olhar sistêmico sobre as cadeias curtas e o consumo consciente de alimentos, trabalhando as relações dos atores para que haja um entendimento de que o alimento é mais que um produto, e seja visto como uma troca de serviços, de relações interpessoais com impactos diretos nas práticas sociais. 
A presente crise no sistema de produção alimentar é uma consequência da lógica do sistema econômico capitalista, que trata comida como commodity, fazendo pouco caso do bem-estar animal e humano, visando a máxima produtividade. Esse pensamento induz a manipulação da natureza e das pesquisas a ela relacionadas, direciona a produção para alto rendimento e padrões estéticos sem levar em conta critérios naturais e nutricionais - empurrando os produtores agrícolas para a produção em massa e de ética duvidosa e incentivando o desperdício com suas políticas de mercado. (Pollan, 2008; Ballantyne-Brodie, 2015. Um trecho do relatório EAT-Lancet de 2019 resume a situação corrente:

"[...] uma transformação do sistema global de alimentos deve, em última instância, envolver múltiplos atores, de consumidores individuais a formuladores de políticas e todos os atores da cadeia de suprimento de alimentos, trabalhando juntos para a meta global compartilhada de dietas saudáveis e sustentáveis para todos." (Willett, Rockström, Loken et al., 2019).

Os consumidores finais e os produtores estão muito distantes na cadeia de consumo, e em realidades sócio-econômica-culturais absolutamente distintas. O cenário é particularmente crítico com os consumidores urbanos, que têm pouca ou nenhuma consciência sobre o que comem, ou sobre a origem dos alimentos consumidos diariamente.

Entre as décadas de 50 e 60, tendo como pano de fundo a escassez de alimentos no pós-guerra e o Baby Boom em países como Estados Unidos, México e Índia, veio à tona a necessidade iminente de ampliar com rapidez a produção de alimentos em todo o mundo, que precisava acompanhar o rápido crescimento populacional (Pingali, 2012). A chamada Revolução Verde, consolidada pelo modelo conhecido como Agronegócio (Piesse, 2017) foi a resposta para tal demanda, implementada para maximizar a produtividade das culturas agrícolas de base, com áreas de cultivo de monocultura cada vez maiores, utilizando herbicidas, pesticidas e fertilizantes químicos. Esse modelo também normatizou o uso das modificações genéticas e massificar a criação de animais para consumo. Essa mudança radical de industrialização da produção rural de alimentos, trouxe altos custos ambientais (restrição da diversidade biológica, contaminação e empobrecimento do solo, dependência de sintéticos, confinamento animal); sociais (condições de vida e saúde dos agricultores) e culturais, culminando na transformação de comida em commodity (Menezes \& Oliveira, 2019).

Pairam questionamentos éticos, como o que leva alguém a produzir comida para seus semelhantes de maneiras tão desumanas com os trabalhadores, com os animais. Ou como o interesse econômico e o capital podem se sobrepor aos direitos 
e condições mais básicas. Ainda nessa seara, pode-se indagar como se permitem situações tão cruéis quanto a utilização de mão de obra escrava infantil no cultivo do cacau, ou empresários que entendem ser natural o salário de um funcionário ser dezenas de vezes o valor do salário de outro. Michael Pollan trata suscintamente de diversas destas questões ao afirmar que

"o preço de 99 centavos de dólar de um hambúrguer fast-food simplesmente não leva em conta o custo verdadeiro dessa refeição - o custo para o solo, o petróleo, a saúde pública (na forma de obesidade e doenças provocadas pela comida) e do meio ambiente (na forma de poluição), sem falar no bem-estar dos trabalhadores nos confinamentos e nos matadouros, e no bem-estar dos próprios animais" (Pollan, 2007, p. 217).

O desligamento do campo, a prática do agronegócio e a necessidade de abstração de questões de bem-estar humano e animal fizeram com que se dissociasse tanto o alimento in natura do que chega ao prato, que para algumas pessoas a imagem mental da fonte do leite é uma caixa, do milho uma lata, e do presunto um bloco semi-retangular rosado.

Nas últimas décadas, uma resposta a essa prática tem tomado força. De alguma maneira, a inovação vem justamente do resgate de métodos tradicionais. $\mathrm{Na}$ seara de práticas agrícolas sustentáveis, dialogam diversos movimentos, como a agroecologia e a agricultura familiar; a permacultura e agriculturas biodinâmica, natural, e ecológica; o comércio justo (fair trade); o Slow Food; o "locavorismo"; o vegetarianismo. A agricultura familiar, em grande parte orgânica, que contraria justamente a exploração desmedida dos recursos naturais e humanos, aponta um novo caminho. Sustentabilidade é a palavra do dia, há décadas, e para isso, o produto ou serviço deve atender às necessidades atuais sem comprometer a futura geração, nos quesitos econômico, ambiental e social. Sob essas égides conceituais, novas características são desejadas pelo consumidor mais consciente: a valorização da origem, ética, local, colonial, sustentável, tradicional, bem-estar animal são alguns dos termos que, como bem coloca Elaine Azevedo (Altoé \& Azevedo, 2020), evocam esses valores.

"Conhecer a procedência dos alimentos, políticas como a de gaiolas livres, alimentos orgânicos e mais artesanais, menores índices de açúcar e sal, entre outras, se tornam evidentes preocupações dos consumidores. A diminuição do desperdício e o melhor aproveitamento também.' (Food Biz Brazil, 2019).

É crescente a preocupação com um mínimo de dignidade dos animais de produção e abate, com a manutenção da biodiversidade, com a relações humanas e naturais envolvidas no processo produtivo. É preciso colocar em posição de destaque a cadeia de consumo. Como, onde, como e por quem o alimento é 
produzido são questionamentos a serem respondidos de maneira fundamental, por todos os integrantes do sistema alimentar (Bellamy \& Loris, 2017).

\subsection{Objetivos}

\section{Objetivo Geral}

O propósito deste estudo qualitativo é estabelecer uma rede de chefs de cozinha que promova, através do design, relações entre produtores, chefs e consumidores, capazes de fomentar um sistema alimentar mais justo, saudável, sustentável e resiliente. Ele visa compreender e ressignificar o papel do chef de cozinha, suas relações com a cadeia curta de produção e consumo de alimentos (CCCA), aproximando-se dos produtores, mudando a maneira como os alimentos são percebidos e consumidos; impactando as relações sociais e econômicas estabelecidas entre o consumidor final e o produtor. Nestes sistemas amplamente consolidados, o chef de cozinha tem a possibilidade de aproximar as pontas da cadeia, promovendo mudanças nas relações de produção e consumo, inovando as relações sociais. Instrumentado pelo Design, esse chef pode criar sentido, valorizando e fomentando o consumo consciente de alimentos.

\section{Objetivos Específicos}

Os objetivos específicos da presente pesquisa são:

- Levantar dados e referências sobre estudos que envolvam Design e Comida/Alimentação (Food Design, Eating Design);

- Mapear chefs que trabalham com pequenos produtores no Rio de Janeiro e casos relevantes no Brasil e entender suas premissas e práticas;

- Evidenciar a importância do chef de cozinha na conexão do produtor e consumidor final, e seu papel na mudança do padrão de consumo/educação do consumidor;

- Desenvolver um artefato que promova o consumo de alimentos cada vez mais consciente, sustentável e acessível, tanto pelos restaurantes quanto pelo consumidor final;

- Despertar o interesse e pensamento crítico sobre os sistemas alimentares em futuros profissionais de Design;

- Contribuir para o estado da arte do Food Design com um estudo sobre as cadeias curtas de produção e consumo de alimentos com foco no chef de cozinha. 


\section{Food Design}

"Eu não consigo pensar em nada mais tocante que a comida. É a alma da vida, o elo de união" 6 (Vogelzang, 2009).

Em seu artigo "What is Food Design", Francesca Zampollo (2016b) escreve o que, segundo ela, deveria ser óbvio. Food Design é composto pela justaposição das duas palavras: "Food Design é tanto sobre comida, quanto sobre Design." 7 Para ela, Food Design é uma disciplina do Design tanto quanto Design gráfico, de produto, de interiores.

A Red Latinoamericana de Food Design (ReLaFD, 2020) traz uma definição ampla do termo, que inclui todas as ações e instâncias, sentidos e escalas que possam melhorar o relacionamento com os alimentos, indo desde o design do material comestível em si, até os sistemas e territórios, passando pelas práticas, interfaces, espaços e experiências conectados à comida. Eles salientam os aspectos comunitários, sociais, ambientais e políticos ligados ao ato de se alimentar.

Zampollo cita também Fabio Parasecoli para contribuir na definição de Food Design, que inclui

"ideais, valores, métodos, processos e atividades que objetivem modificar, melhorar e otimizar interações individuais e comunais em torno da comida, incluindo, mas não se limitando a, materiais comestíveis, objetos, experiências, ambientes naturais e construídos, serviços, sistemas e redes" 8 (2016b, p.7)

consolidando que Food Design pode da mesma forma se apropriar das questões relacionadas aos impasses da produção agrária e industrial do alimento, aos processos de colheita, beneficiamento, distribuição, bem como de compra e venda, transporte, armazenamento, preparo e finalmente o consumo e ainda do modo como restaurantes trabalham e servem os insumos, dos papéis que a comida desempenha nas relações e vidas humanas.

As definições e nomenclaturas são ainda bastante fluidas, e até conflitantes por vezes, e abrangem toda forma de interação entre design e comida ou ato de comer, em que estes são o objeto sobre o qual o design se debruça.

\footnotetext{
6 "I can't think of anything that touches us like food. It is the soul of life, a single unifier."

7 "Food Design is as much about food, as it is about Design."

8 "[...] ideas, values, methods, processes and activities aiming to modify, improve and optimize individual and communal interactions with and around food, including but not limited to edible materials, objects, experiences, natural and built environments, services, systems and networks."
} 
O que importa talvez seja menos a assertividade desse enunciado, visto que o tópico vem sendo trabalhado desde o início dos anos 2000 e não se chegou à uma conclusão da definição, nem sequer sobre o uso de Eating Design ou Food Design, e mais estabelecer que há diversas relações e possibilidades de se trabalhar o design com a alimentação, seja de forma artística, projetual, conceitual, social, sistêmico. Todas elas tendo, como conceito de base, o usuário, preceito indispensável para que se caracterize como projeto de design (Lowdermilk, 2013; Norman, 2013).

Nesse vasto repositório, a falta de consenso é tanto sobre a definição quanto sobre o uso das expressões anglófonas Eating Design e Food Design. Martin Hablesreiter e Sonja Stummerer (2009) trazem uma definição prática, em que Food Design seria a disciplina que se ocupa de todas as etapas, da produção à partilha da comida. Para os autores, isso inclui todos os processos e decisões relacionadas ao design dos alimentos de forma reprodutível e recorrente.

Durante o evento EFood Lisboa 2019, Sonia Massari apresentou três grandes segmentos do Food Design diretamente relacionados à sociedade, dois dos quais serão abordados ao longo desta pesquisa: "The educational role of Food Design" e "Creative sustainable (food) Systems" (EFood 2019). No evento, Massari tratou das relações humanas com a comida, das questões ligadas à sustentabilidade, e do papel do designer na construção cenários

"[...] nos quais a comida anda de mãos dadas com sistemas inovadores. Dentre essas (profissões), a de Food Designer parece ser uma carreira promissora para futuros profissionais que queiram aplicar suas habilidades além do setor da alimentação. [...] A conclusão da minha fala foi um chamado à ação direcionado a todos, e particularmente aos designers e inovadores que lidem com o setor da agroindústria e alimentação: nós temos que desenhar e propor cenários visionários. Nós deveríamos inspirar a humanidade. Talvez devêssemos chocá-la. Ou meramente tocá-la. Mas apenas através de nossas ideias e projetos futurísticos de design é que poderemos mostrar para as gerações presentes que um mundo diferente é possível. Nós poderemos mostrar a eles que um mundo sustentável não é apenas imaginável, mas alcançável. Precisamos projetar nosso mundo futuro revolucionário a partir de hoje. Precisamos vislumbrar cenários sustentáveis" 9 (EFood, 2019)

9 "where food goes hand in hand with innovative systems. Among these, the Food Designer seems to be a promising career for future professionals who want to apply their skills beyond the food sector. [...] The conclusion of my speech was a call to action addressed to everybody, and particularly to designers and innovators who deal with the agri-food sector: "we have to design and propose visionary scenarios. We should inspire the humans. Maybe we should shock them. Or only hardly touch them. But only through our futuristic design projects and ideas will we be able to teach today's generations that a different world is possible. We could show them that a sustainable world is not only imaginable, but also achievable. We need to design our revolutionary future world from today. We need to envision sustainable scenarios." 
$\mathrm{Na}$ justaposição das definições de comida e design, pode-se dizer que enquanto o design é um campo que se ocupa de imaginar e resolver questões pósteras, a comida, uma necessidade básica, é um tema vasto, repleto de indagações futuras e possibilidades de projeto, tanto no design tátil (produtos, gráfico) quanto no imaterial (serviços, sistemas e relações).

"A comida é o material mais importante do mundo. Quando faço design você cheira, sente, prova, e você de fato o coloca dentro do seu corpo. O design será efêmero e irá se desintegrar sem deixar rastros. Apenas sua memória perdurará." ${ }^{10}$ (Vogelzang, 2010).

Em uma abordagem semântica, as definições mais simples e genéricas de Design, termo anglófono (Cambridge, 2019), denotam algumas variações de significado quando da tradução para o português:

- Design como verbo: projetar ou desenhar, a maneira como algo é planejado ou desenhado;

- Design como substantivo: a forma física ou o conceitual de um objeto; o padrão decorativo, artístico.

Ainda na busca das definições mais básicas dos termos fundamentais desta pesquisa, o dicionário Cambridge (2019) denota comida como:

- aquilo que pessoas e animais comem, ou plantas absorvem, para manteremse vivos; sinônimo de alimento e traduzido como food.

- comer como o ato de ingerir comida ou alimentos, alimentar-se, traduzido como eat.

Partindo destas definições, William Miller (1988) deixa claro que a definição de design é a ação, o processo, projeto, sendo, portanto, a definição do verbo, referindo-se à atividade em si, e não aos produtos originados dela. Assim, segundo seu enunciado simples, "Design é o processo de pensamento que compreende a criação de alguma coisa." 11

John Heskett definiu design como "capacidade humana de formar e fazer nosso ambiente de maneira que ele satisfaça nossas necessidades e dê significado às nossas vidas" (Heskett, 2005). Francesca Zampollo (2016b) cita essa mesma

10 "Food is the most important material in the world. When I make a design you can smell it, feel it, taste it and actually put it inside your body. The design will be ephemeral and will disintegrate without a trace. Only your memory will last."

11 "[...] design, stripped to its essence, can be defined as the human capacity to shape and make our environment in ways without precedent in nature, to serve our needs and give meaning to our lives." 
definição e enfatiza que ambiente é qualquer estímulo com o qual o homem possa interagir. Seguindo essa definição mais contemporânea de design, a profissão é tida como uma interação de conhecimentos das artes e ciência, com responsabilidade, e com um olhar para as indagações cotidianas, integradas, que combinem prática e teoria. De acordo com Groll \& Hunter (2015, p.113) "design é uma atividade fundamental, com ramificações capilares em todas as atividades humanas, por isso, nenhuma profissão pode pretender ter o monopólio do design."

A permeabilidade do conceito de Design e a academização da profissão possibilita a entrada de disciplinas não projetuais no curso, o que, em certa medida, mesclam critérios acadêmicos com a experiência profissional, e componentes projetuais da disciplina. Essa é a característica decisiva da pesquisa em design. O cerne da educação para a profissão do design é projetual, baseada em compreensão e pensamento crítico, diferente do que segue a maioria das universidades, com a divisão por disciplinas.

Pode-se dizer que fazer design com/para/sobre alimentos está contemplado no proposto por Bonsiepe (2015), ao determinar que o design se aplica a qualquer área do conhecimento, com foco em ações efetivas para a inovação, ligado ao usuário e ao espaço.

Sendo o alimento ou a comida o material de trabalho do designer, as possibilidades vão se construindo, e os conceitos se encaixando para designar efetivamente o escopo de trabalho e possibilidades de ação projetual e de estudos do campo do Design.

"Porém nem tudo é design e nem todos são designers. O termo 'design' se refere a um potencial ao qual cada um tem acesso e que se manifesta na invenção de novas práticas da vida cotidiana. Cada um pode chegar a ser designer em seu campo de ação." (Bonsiepe, 2015, p. 13).

Design com o objetivo da inovação social traz consigo a característica de se ocupar das preocupações de uma comunidade de usuários, colocando ferramentas à sua disposição. O designer do século XXI possui um misto de sensibilidade, técnica e cultura, que podem ser aplicados para resolver problemas de todos os tipos, desde o tradicional conceito de um produto-objeto, à co-criação de um serviço social, ou propostas de novas formas de representação democrática. O Design contemporâneo é baseado em inovação, participação, co-design e idealmente centrado no usuário. Esses preceitos, claros no Design Thinking, além de estarem alinhados às necessidades da sociedade, instrumentaram, com seus kits de ferramentas e métodos, tanto designers ditos experts quanto indivíduos menos habilitados, auxiliando na criação de soluções para questões tão variadas quanto infraestrutura 
urbana até serviços de compartilhamento de babá (Meroni, 2018; Zampollo \& Peacock, 2016).

Em seu livro "Design, when everybody designs" (2015), Manzini distingue ainda duas categorias maiores de design, o "difuso", que todos são capazes de fazer, e o "especialista", feito por aqueles que foram treinados para serem designers, e descreve como as interações entre esses atores ocorrem. Ele fala sobre a capacidade individual ou coletiva de elaborar estratégias, soluções e significados e colocá-las em prática para produzir inovação social; tratando os designers experts como profissionais da sociedade qualificados para promover e dar suporte a diversos processos de design, em diferentes escalas. Por isso é necessário, quando todos podem fazer design, que haja um profissional para dar assistência, com bagagem cultural e técnica para integrar e promover as habilidades dos não-experts.

Para Teresa Franqueira (2009), a profissão está se modificando, a medida em que os usuários interferem ou participam dos processos criativos, e o papel do designer nesse novo contexto é exercer seu ofício como um gestor, fortalecendo os conceitos de comunidades criativas, design colaborativo e co-design, com foco na inovação, no estímulo da economia local, nas transformações sociais, na sustentabilidade (EMUDE, 2006; Meroni, 2007). A atividade do design abarca todo o ciclo de vida do objeto, serviço ou sistema, trazendo inovação e humanização nas esferas cultural e econômica.

Ainda nessa mesma linha da ação profissional, ficam claras as responsabilidades do designer como ator de um meio cultural particular e seu papel de interlocutor, promovendo interação das diferentes redes de ofertas e demandas, parceiros, interações, proporcionando as ferramentas, o storytelling e o suporte para facilitar a implementação dos diversos projetos e experiências de maneira iterativa. (Ballantyne-Brodie, 2013).

Algumas abordagens do Design que são particularmente interessantes para esta pesquisa conectam a maneira processual de pensamento dos designers à solução de problemas das novas demandas da Era Moderna. São elas: Design Thinking, Design de Serviço e Design para Inovação Social.

Chiara Del Gaudio trata do Design para Inovação Social como uma ferramenta de empoderamento das pessoas através do processo de design, envolvendo os usuários como participantes ativos, com foco na sustentabilidade. Ela afirma que

"diferente daquele design para produção industrial, em que as pessoas eram consumidores, estamos tratando de um caminho que desconstrói a figura do consumidor apenas, coloca a pessoa como usuário, no centro do processo de design, e conduz ao entendimento de um design feito com as pessoas, em coautoria." (Gaudio in: Oliveira, 2017, p. 22). 
Para Nigel Cross (2006), a forma de pensar do designer é focada na solução do problema, e não no problema em si, como os cientistas normalmente fazem. O Design Thinking é a forma de pensar do designer, e Cross cita Simon ao relatar que os designers resolvem um problema satisfazendo, e não necessariamente otimizando:

"produzindo qualquer uma (solução) que seja, dentre muitas soluções, ao invés de tentar gerar uma única solução, hipoteticamente perfeita. Essa estratégia foi observada em outros estudos de comportamento de design, incluindo arquitetos, desenhistas urbanos e engenheiros" ${ }^{12}$ (Cross, 2006, p.18).

Do mesmo modo, ao se projetar um serviço, e não um objeto como solução de um desafio de design, o Design de Serviço trabalha as interações e as experiências do usuário; planejando as formas de contato, as relações e as evidências possíveis para um serviço.

O design traz em sua essência uma abordagem holística e participativa, buscando entender as perspectivas humanas e organizacionais para traduzir em serviços e produtos. Uma aproximação integradora para inovar em sistemas complexos e mudanças sociais, utilizando de ferramentas de visualização, representação e co-criação.

A Figura 03 mostra os processos criativos do Design sobre a comida pelo olhar de Marije Vogelzang. A esfera central, no topo, engloba princípios norteadores do Design Thinking - pesquisa, observação, experimentação, ideação e expressão conectados aos aspectos sociais e culturais, e vinculados ao despertar da consciência e comunicação. Ainda no centro Marije fala como o Design pode valorizar, trazer interesse e formar relações com a comida. A ilustração expande e detalha as relações, apontando aspectos do Food Design como forma, padrões, histórias, o papel da comida e os sistemas alimentares futuros. Especial foco será dado nesta pesquisa a esse último tópico, apresentado no canto inferior esquerdo, que aborda, entre outros, as relações entre produção e consumo, os sistemas produtivos, soluções para os ciclos/cadeias alimentares.

12 "producing any one of what might well be a large range of satisfactory solutions rather than attempting to generate the one hypothetically-optimum solution. This strategy has been observed in other studies of design behavior, including architects, urban designers, and engineers". 


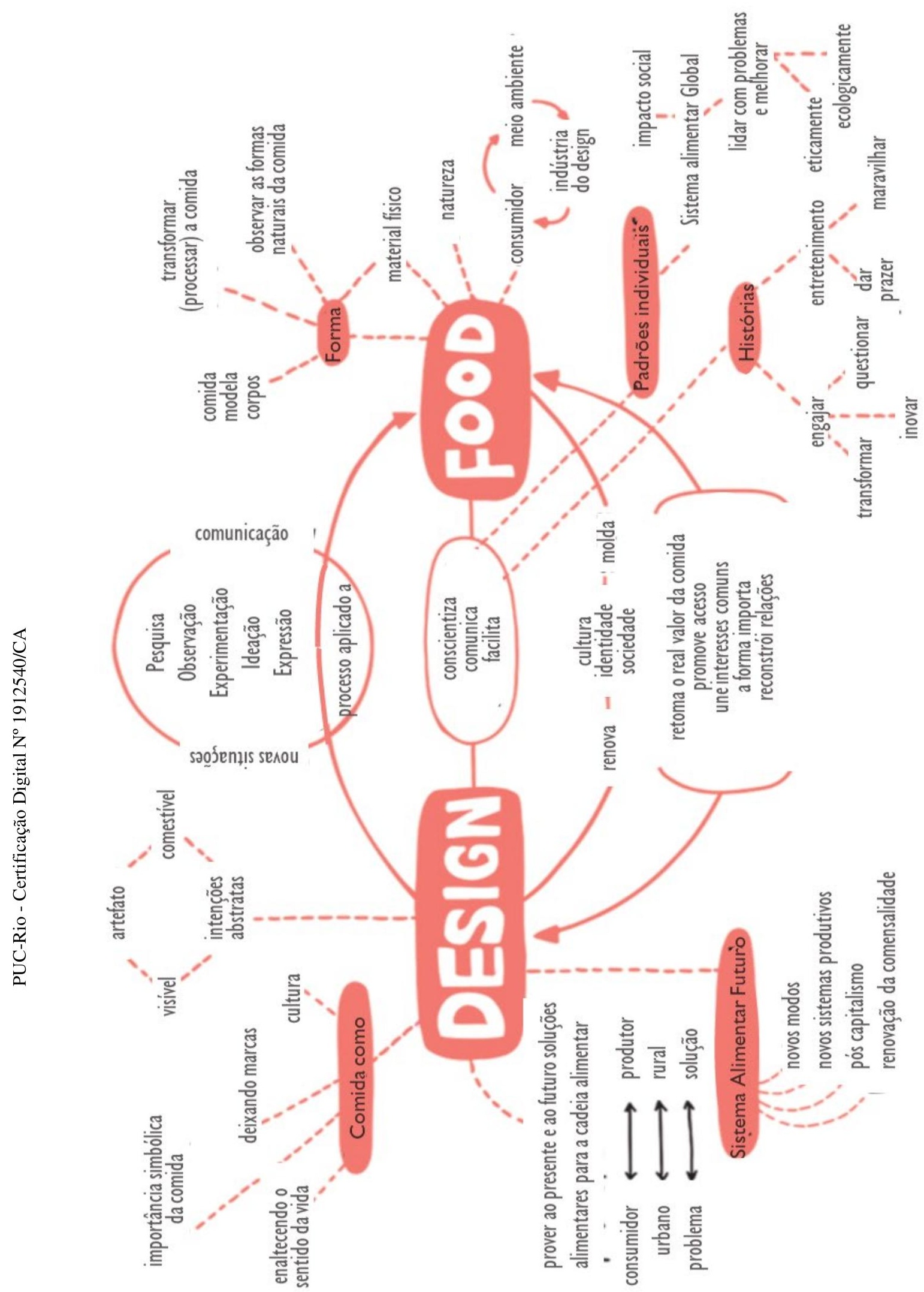

Figura 03 . Food Design Manifesto Map, Su Hyuyn Park (in Vogelzang, 2018).

Colocar desafios do porte dos sistemas alimentares e hospitalidade nas mãos dos designers é uma oportunidade de ampliar o escopo dos projetos, trazer qualidade visual e de comunicação, e, com a ajuda dos especialistas da 
alimentação, chegar a resultados de grande riqueza para a área (Lee, Breuer \& Schifferstein, 2020).

Para o food designer Pedro Reissig, o seguinte pode ser posto em relação à comida e ao alimento:

"[...] é a matéria-prima de nossa vida física, biológica e fisiológica como organismos vivos, sendo literalmente vital para a nossa existência, crescimento e continuidade. Faz parte de nossos instintos em vários níveis, que se manifestam de várias maneiras, como reflexos de fome, salivação e outras reações corporais. É o ato de ingerir matéria orgânica que passa a ser nosso próprio corpo, portanto, não é apenas 'combustível, é também 'produção e crescimento'. É um processo de transformação química e biológica tão incrível quanto concreto, e geralmente não é algo sobre o qual refletimos muito. É um evento muito íntimo e pessoal, colocar matéria externa em nossa boca e ingeri-la. É uma parte intrínseca da nossa vida diária: pensar, planejar, executar e gostar de comer. Tem um impacto direto na nossa saúde, para melhor ou para pior, implicando considerações éticas e morais a nível pessoal e social, para além dos aspectos legais, políticos e culturais. Envolve uma multiplicidade de atores diversos, setores, tomadores de decisão, influenciadores etc. Envolve cadeias de valor e transformação de enormes dimensões a nível industrial, comercial e econômico, tão grandes e complexas que são quase incomensuráveis. Organiza nossa identidade individual e coletiva, bem como práticas culturais derivadas." ${ }^{13}$ (Reissig, 2019).

O texto de abertura da exposição "Pratodomundo - Comida para 10 bilhões" (Menezes \& Oliveira, 2019), ilustra o envolvimento indissociável da sociedade e alimentação ao afirmar que alimentar-se é mais que nutrir o corpo, é também se relacionar com pessoas, com a Terra. É estimular a consciência sobre as escolhas alimentares e suas consequências políticas e sociais: "a escolha do que colocamos em nosso prato e do que deixamos nele torna-se uma responsabilidade individual e coletiva, já que afeta a comunidade e o meio ambiente."

O "Atlas Visual de Food Design" (Reissig, 2019) arremata o sortimento de conceitos de maneira abrangente, concluindo, sobre Food Design:

13 "[...] it is the raw material of our physical, biological and physiological life as living organisms, being literally vital to our existence, growth and continuity. It is part of our instincts at various levels, which manifests itself in various ways, such as hunger reflects, salivation and other bodily reactions. It is the act of ingesting organic matter that becomes our own body, so it is not only "fuel", it is also "production and growth". It is a process of chemical and biological transformation as incredible as is concrete, and is not usually something on which we reflect too much about. It is a very intimate and personal event, putting external matter in our mouths and ingesting it. It is an intrinsic part of our daily lives: thinking, planning, executing and enjoying eating. It has a direct impact on our health, for better or worse, implying ethical and moral considerations on a personal and social level, beyond legal, political and cultural aspects. It involves a multitude and diversity of actors, sectors, decision makers, influencers, etc. It involves chains of value and transformation of enormous dimensions at industrial, commercial and economic level, so large and complex that they are almost immeasurable. It organizes our individual and collective identity as well as derived cultural practices." 
"esta é uma visão construída para caminhar em direção a uma melhor qualidade de vida em relação à comida e tudo o que isso implica, desde o básico e vital que a nossa ligação é, às inúmeras implicações inerentes à comida e alimentação, como saúde, cultura, identidade, produção, economia, e assim por diante. Esta definição vai além da intersecção entre comida e design, uma vez que estamos em um momento crítico mundial no que diz respeito a muitos princípios básicos questões da vida, especialmente comida e alimentação, onde os paradigmas atuais desabam sozinhos e imploram por novos caminhos. Food Design nos convida a colocar os alimentos em perspectiva, nos empoderar para conectar, ver e entender o que está acontecendo ao nosso redor, começando por nós mesmos, com mudanças desejadas, extensíveis à comunidade, áreas sociais, políticas e outras áreas onde a comida está presente." ${ }^{14}$

Ao se voltar para as questões da comida e alimentação, o Design está olhando para um conjunto de sistemas de produtos e serviços diretamente ligados à atividade humana mais basal, que é comer, e que perpassa as esferas sociais, políticas, econômicas e todos os sistemas a elas ligados.

A Figura 04, a seguir, mostra uma suscinta linha do tempo dos registros na literatura acadêmica e da prática de Food Design.

Enquanto este capítulo trata das interações entre Design e Comida, o subcapítulo 2.2 tratará da Comida e suas relações com mais profundidade, bem como os conceitos médicos, estéticos, políticos e sociais que perpassam essas definições.

\footnotetext{
14 "this is a vision built to move towards a better quality of life in relation to food and everything that it implies, from the basic and vital that our connection is to it, to the innumerable implications inherent in food and eating, such as health, culture, identity, production, economics, and so on. This definition goes beyond the intersection between food and design since we are at a critical moment worldwide with respect to many basic issues of life, especially food and food related, where current paradigms collapse alone and beg for new paths. Food Design invites us to put food into perspective and empower ourselves to connect, see and understand what is happening around us, starting with ourselves with the desired changes, extendable to the community, social, political and other areas where food is present." (Reissig, 2019)
} 


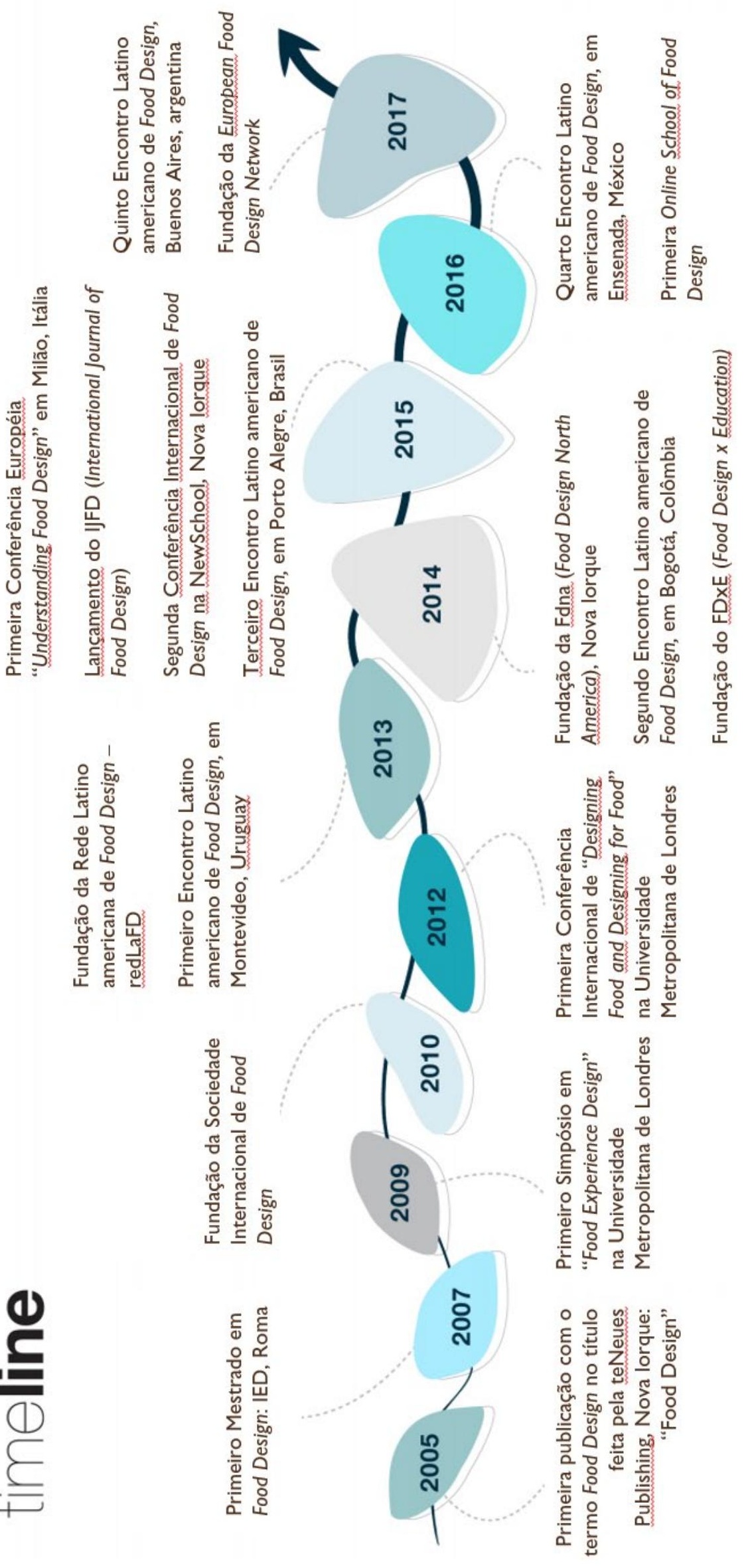

Figura 04 . Linha do tempo do Food Design (Reissig, 2019). 


\subsection{Food Design destrinchado}

"A primeira coisa a que as pessoas ligam à expressão Food Design é 'como se arranja a comida no prato'. Não. Food Design não é food styling. Ou pelo menos não só. Food Design é muito mais." 15 (Zampollo, 2016b).

A miríade de produtos e processos ligados aos alimentos e à comida, em geral, aliado à transdisciplinaridade do termo Food Design, resulta em confusão quanto à conceituação, ou ainda, abrangência da expressão. A prática de Food Design é tão antiga quanto a do design, como processo de geração de ideias e inovação, e pode ser considerado como a aplicação de tudo que já foi definido como Design (da prática ao campo de estudo) sobre a comida e alimentação.

Anna Meroni (2006) fala sobre a transição das questões tratadas inicialmente pelo Food Design, um pouco limitadas à estética do alimento e suas ferramentas de produção, quando a disciplina passa a abordar os serviços gastronômicos e os paradigmas da alimentação do século XXI. A autora aborda o design sistêmico voltado para os alimentos como um processo de entendimento e desenvolvimento territorial, em que o uso dos recursos naturais, o local, a sociedade são todos parte do sistema que se inter-relaciona (Meroni, 2006, 2017). Ainda sobre o design de sistemas alimentares, Meroni fala sobre as mudanças necessárias no modo como se produz, consome e representa comida, e na inovação social que se faz possível através do design ativista.

Seguindo inquietações similares, o escritório IDEO tem Lynda Deakin (2019) à frente de um novo departamento: Design for Food Studio, cujo escopo de trabalho se baseia em utilizar o Design Thinking para inovações sustentáveis nos sistemas alimentares, atacando diversos pontos dessa rede, propondo desde alterar padrões de consumo até instigar os indivíduos das grandes corporações da indústria alimentícia, passando por organizações, políticas públicas e pequenos produtores. Para ela, independente das ações ou escalas, o foco são as macro questões globais, como uso de água e solo, agricultura industrial tradicional, mudanças climáticas, obesidade, desperdício, acessibilidade, entre outros.

15 "The first thing people always assume when they hear the words Food Design, is that it's about "how you put stuff on a plate". No. Food Design is not food styling. Or at least, not only. Food Design is much more." 
O departamento de Deakin trabalha sobre quatro eixos no que chamam de Design for Food, que envolvem igualmente o consumidor, os métodos de produção e processamento dos alimentos:

- soluções sustentáveis; como novas tecnologias e novos modos de produzir agricultura, mudança nos padrões de consumo de determinado tipo de alimentos;

- reconstrução da confiança culinária; apostando na escala doméstica e na reconexão com os alimentos;

- comida e saúde; rompendo as fronteiras de ambos, vendo comida como cura, os micro biomas humanos;

- e finalmente o chamado big food, na aposta da mudança através da escala, apostando nas grandes empresas, hotéis, restaurantes, com projetos para os próximos 10 a 15 anos.

Lynda mostra alguns estudos em andamento, em fase de ideação na sua maioria, e revela abordagens com diferentes níveis econômicos e sociais, público e privado, propondo inovações tanto no fast food, como também com novos conceitos como foodbank e food pharmacy. Deakin acredita que é possível causar impactos positivos no planeta se for seguido o rumo correto. Ela afirma que não se pode fazer design para o futuro pensando nos comportamentos de hoje. Deve-se fazer design para comportamentos emergentes, que serão novos padrões de comportamento (Deakin, 2019).

Marije Vogelzang autointitulada Eating Designer, atua nesse mercado desde o fim dos anos '90, inaugurnado em 2014 o primeiro curso superior de Food Design, no Dutch Institute of Food \& Design, em Eindhoven, chamado Food Non-Food. O intuito do curso é aprofundar as discussões, solidificar uma formação específica e garantir o futuro do Food Design. Assim como o próprio Design, Marije acredita que Food Design seja uma profissão ainda em consolidação, que tem conquistado seu espaço e importância, e ilustra esse raciocínio com a primeira conferência acadêmica sobre o tema do Food Design, por exemplo, em 2012 (Reissig, 2019).

Para Vogelzang (2015), Food Design trata especificamente de projetar com alimentos, enquanto Eating Design é um campo mais abrangente, pois trata do comer como um todo, desde a colheita, partição, cozimento e tudo o que se relaciona com isso, e com Design Thinking. Ela lista sete pontos em que design e comida se cruzam: sentidos, psicologia, materiais, natureza, ciência, cultura e sociedade. E completa que Eating Design pode se ocupar igualmente dos sistemas, rituais e serviços relacionados ao comer. Como última análise, ela aborda os chefs 
de cozinha, enfatizando que de fato, alguns chefs podem ser chamados de designers, particularmente no trabalho de criação, com soluções inovadoras e artísticas.

Mentora da Online School of Food Design, Francesca Zampollo tem um olhar esmiuçado sobre as práticas e particularidades do Food Design, e sugere o Food Design Thinking (2016) como um conjunto de metodologias de design para facilitar o desenvolvimento de sistemas alimentares. Em contraponto ao Eating Design de Vogelzang, Francesca considera Food Design a terminologia mais abrangente:

"Food Design é, simplesmente, a conexão entre comida e design. Food Design são os processos de design que almejam inovação em produtos, serviços e sistemas para comida e alimentação: da produção, preservação, comercialização e transporte à preparação, apresentação, consumo e descarte." ${ }^{16}$ (Zampollo, 2013c).

Sob essa ótica, pode-se categorizar como Food Design não só o trabalho de diferentes profissionais, incluindo os não designers, como produtos e serviços tão distintos quanto formatos de massa, chocolates. As subcategorias propostas por Francesca em 2013 e revisitadas em 2016 se interceptam e completam.

- Food Product Design: é o Design de produto, em que a matéria prima da produção é comestível, particularmente voltado para a indústria de alimentos processados (massa, chocolate, salgadinhos). Geralmente desenvolvido por um designer de produto, com conhecimento em embalagens e parceria com profissionais especializados em ciência aplicada à alimentação.

- Design for Food: trata de projetar produtos para preparar, cozinhar, servir, conter e transportar comida, como potes, panelas, talheres, louça, equipamentos como liquidificador até impressoras 3D e embalagens em geral. Um profissional com background em design de produto e gráfico, e trabalha muito próximo à especialistas em alimentação. É diretamente ligado ao Food Product Design.

- Design with Food: todos os produtos criados por um chef de cozinha que expande as fronteiras das artes culinárias, na forma de produtos alimentícios prontos para o consumo imediato (pratos de um restaurante, bolos, pães...). Certamente depende de conhecimentos e experiência na elaboração e

16 "Food Design is, simply, the connection between Food and Design. Food Design is the design process that leads to innovation on products, services and systems for food and eating: from production, preservation, procurement and transportation to preparation, presentation, consumption and disposal". 
preparo de alimentos. Nessa categoria podem estar enquadrados os chefs de cozinha (desde que tragam a instância de inovação para o campo profissional). Está diretamente ligado ao Design for Food na medida em que o recipiente em que o alimento é servido/transportado tem influência direta sobre a experiência.

- Food Space Design: o projeto de todos os espaços em que se consome ou produz alimentos, não restritos a cozinhas industriais, restaurantes e cafés, por exemplo, mas englobando lugares como cinema, avião, food truck etc. Aqui trabalham profissionais de design de interiores ou arquitetos colaborativamente com especialistas do ramo culinário. Intersecta com frequência Design with Food, já que, da mesma maneira que os recipientes, o espaço de preparo e consumo dos alimentos implica nas diferentes experiências e apresentações dos produtos consumidos.

- Design about Food: design de objetos com a temática da comida, com a ideia de interpretar ou caracterizar a mensagem desse produto, sem, contudo, utilizar a comida como matéria prima.

- Eating Design: a situação única do comer em si, como o serviço de catering para eventos, uma instalação artística, ou qualquer situação em que o designer controla a maior parte dos aspectos projetuais, em que toda a experiência é pensada para esse momento: o entorno, a louça, o serviço etc. Pode tangenciar ou intersectar com o Food Space Design, Design for Food e Design with Food em diferentes intensidades.

Até 2013 essas foram as categorias trabalhadas por Zampollo (2013), que foram revistas em 2016, ganhando os seguintes acréscimos:

- Food Service Design: Design de Serviço aplicado à alimentação e ao comer. É possivelmente o campo de mais futuro na seara do Food Design, e que deve concentrar olhares, abrangendo também as interações, os espaços, o relacionamento com o cliente e a centralidade no usuário, e todos os atores da frente de cena e da produção, em um sistema com múltiplas interações e aplicações. Esta subcategoria do design abarca totalmente o Eating Design, e pode se relacionar em diversas formas e intensidade com as demais categorias apresentadas, considerando sempre a não interação ou interação não programável, como quando um serviço acontece em uma plataforma digital, ou no ambiente doméstico.

- Critical Food Design: é a disciplina que traz reflexões sobre o tema, incita preocupações, ações e debates sobre a situação atual e os futuros cenários. 
Engloba potencialmente todas as demais subcategorias, mesmo quando de forma não explicitada ou intencional.

- Food System Design: o grande círculo que engloba os anteriores, aliado ao pensamento de origem e destino dos processos/materiais, como, por quem e para quem são feitos. Quais são os objetivos, os valores, as métricas? Tudo o que é tangível no universo do alimento é parte deste sistema maior.

- Sustainable Food Design: e finalmente, o termo que envolve tudo o que foi apresentado, apoiado na consciência e atitude que, na realidade, todo designer deveria ter ao desenhar qualquer coisa. Poderia ser, de certa forma, o ponto inicial de todo projeto.

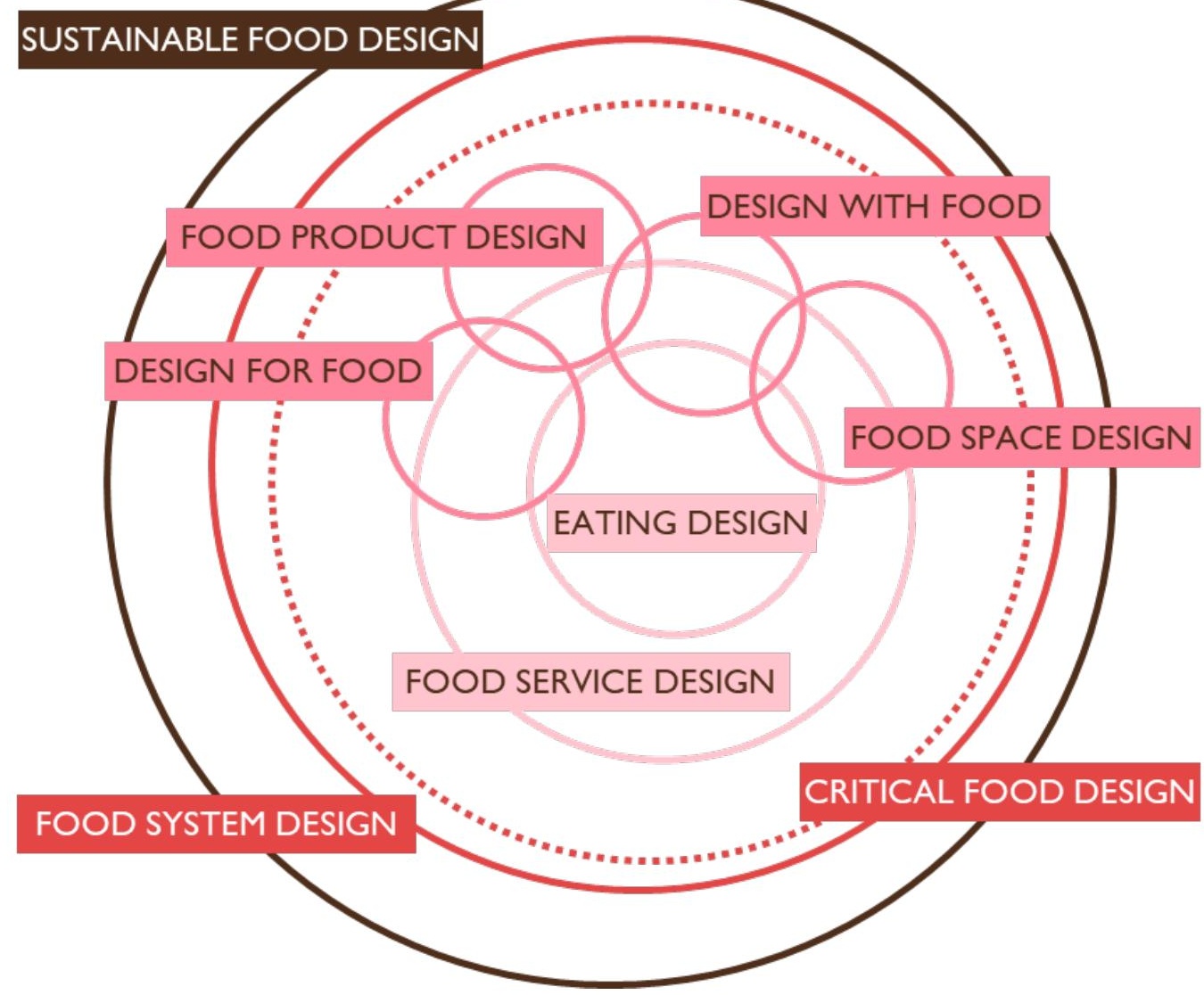

Figura 05 . Subcategorias de Food Design segundo Zampollo (2016b). 
As figuras abaixo apresentam alguns exemplos projetos de Food Design:

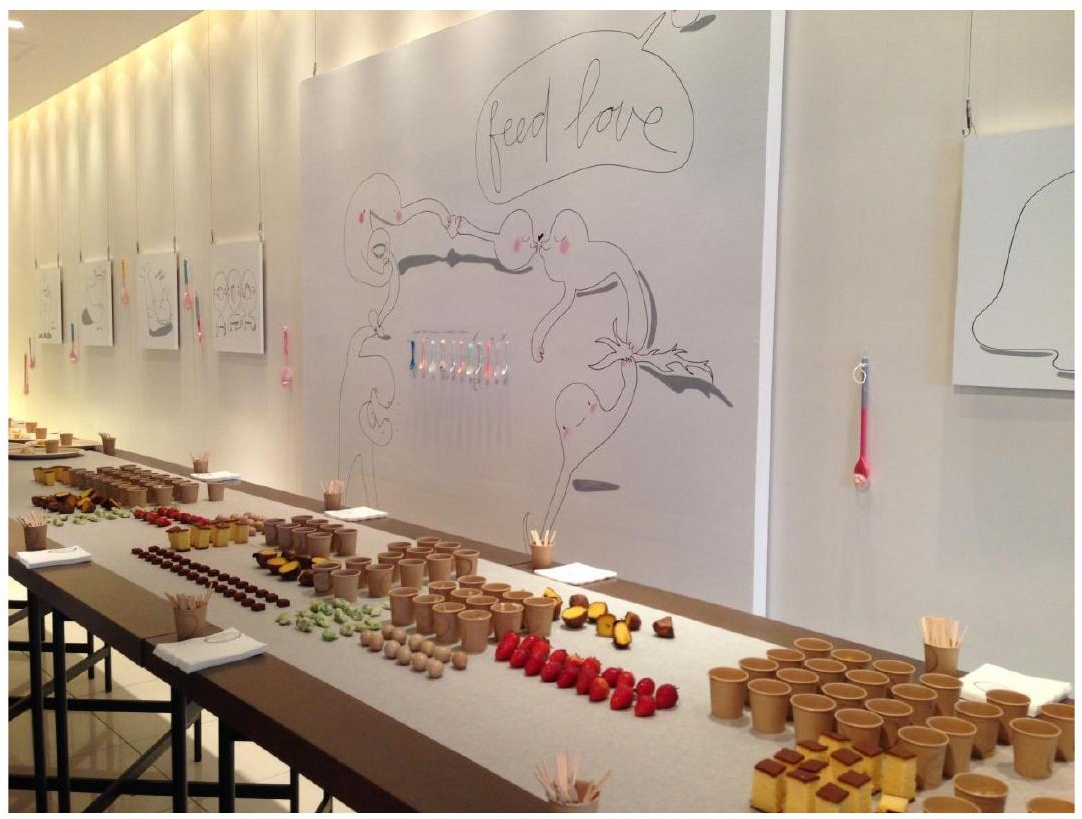

Figura 06. Exibição interativa "Eat Love Budapest", de Marije Vogelzang (marijevogelzang.nl)

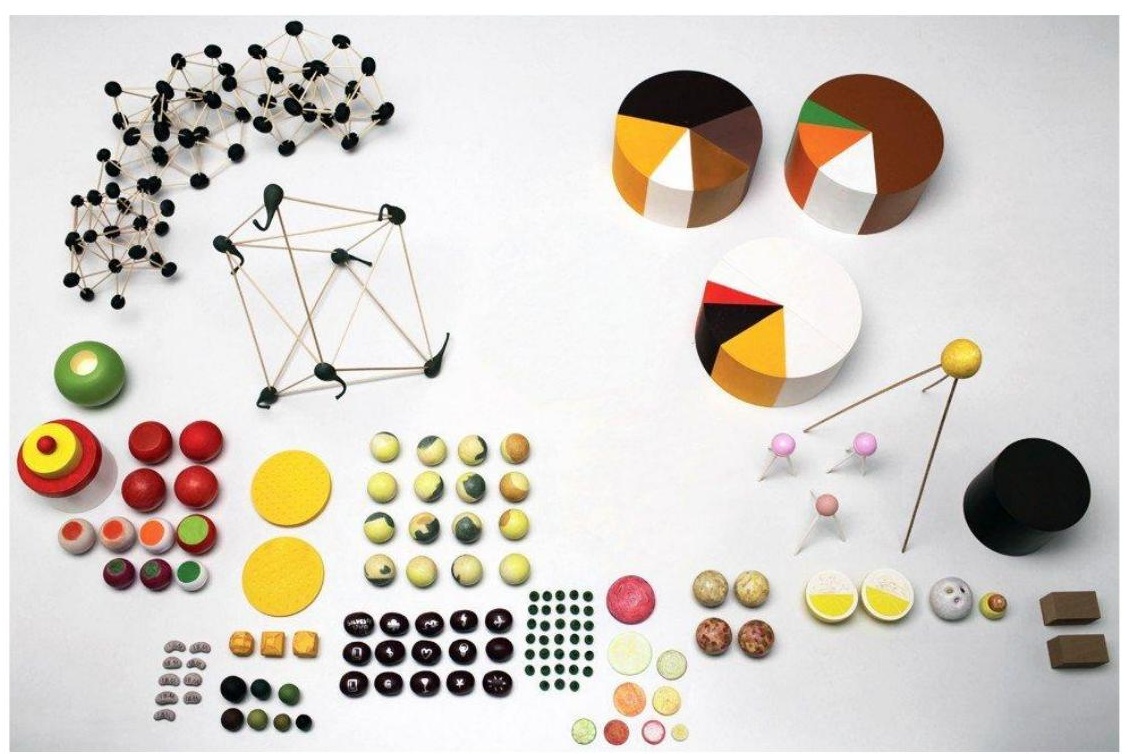

Figura 07 . Objetos comestíveis (www.scuoladesign.com).
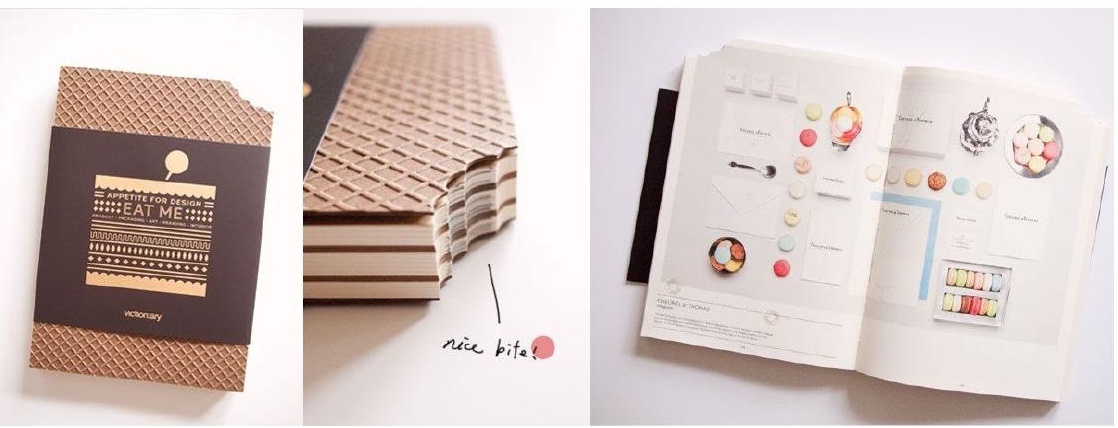

Figura 08 . Livro "Eat me: Appetite for Design" (2013). 

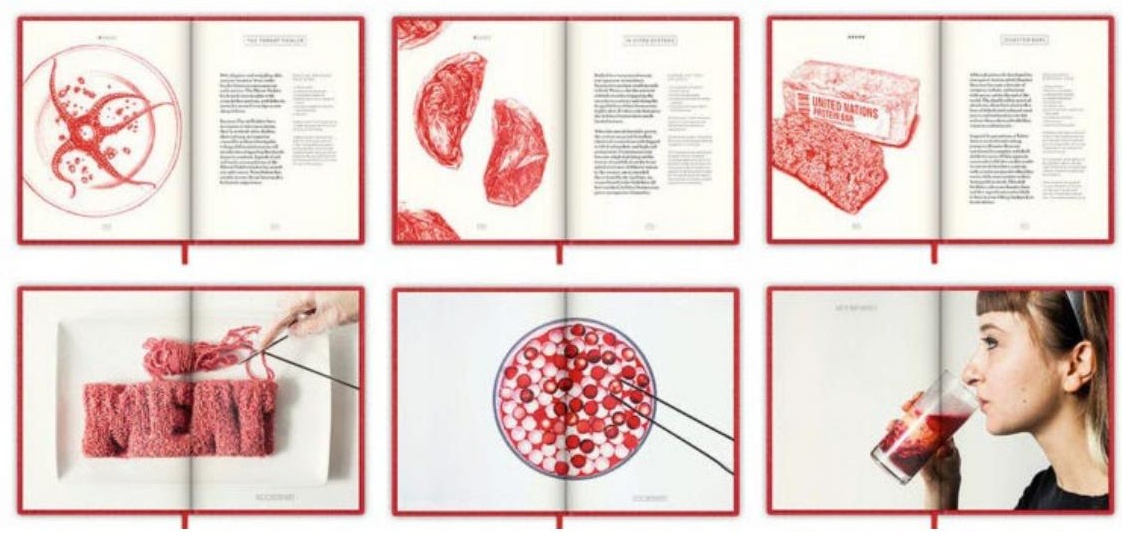

Figura 09 . Livro "The in vitro meat cookbook" (2014).

\subsection{Fundamentos do Food Design}

Dado que Food Design é, portanto, toda a atividade de design relacionada tanto ao design material de objetos de consumo ou eventos, de forma artística ou projetual, quanto ao design imaterial, de sistemas e serviços ligados ao ato de comer, o passo seguinte é determinar alguns elementos sem os quais não existe o Food Design.

Ainda segundo Francesca Zampollo (2017), Comida, Sociedade, Meio Ambiente e Tecnologia são os quatro pilares que permitem aos chefs, designers e outros profissionais ligados às inovações gastronômicas embasar projetos de Food Design.

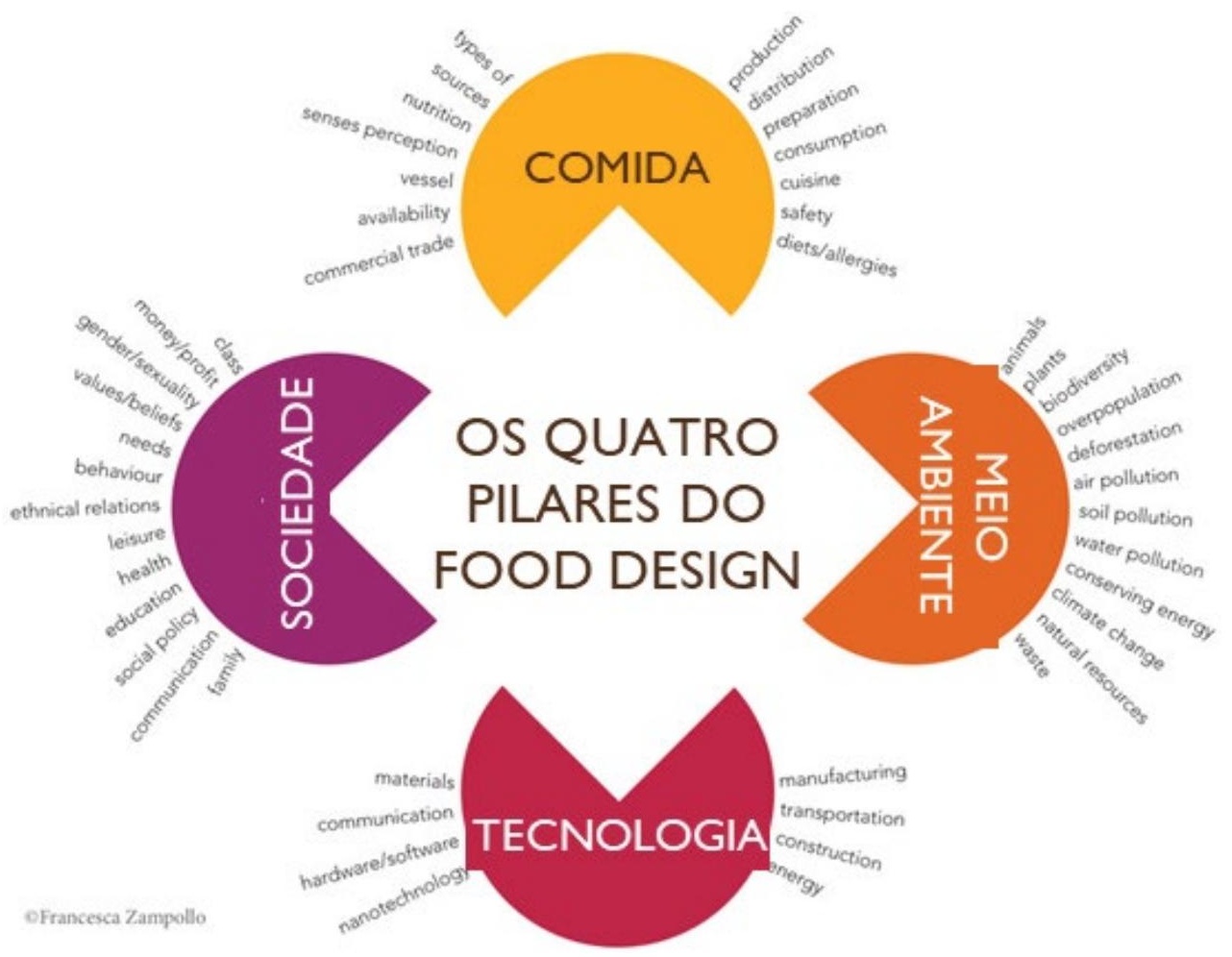

Figura 10. Os quatro pilares do Food Design (Zampollo, 2017). 


\begin{abstract}
"Estas são as quatro áreas que os Food Designers devem investigar ao projetar qualquer coisa relacionada à design e alimentação, independentemente de estarem projetando um prato, um evento, um serviço de alimentação ou um sistema alimentar inteiro: todo prato, todo produto, todo evento e todo serviço de alimentação faz parte de um sistema e cada sistema de alimentação se assenta nestes quatro pilares. Cada sistema alimentar é constituído por elementos desses quatro pilares e, dentro de qualquer projeto de Food Design, deve-se projetar aspectos (ou considerar aspectos) de cada um desses quatro pilares." ${ }^{17}$ (Zampollo, 2017)
\end{abstract}

De acordo com os Objetivos de Desenvolvimento Sustentável da ONU, um modo de vida mais sustentável é peça chave na conservação e proteção de todas as formas de vida no planeta. Isso está intimamente ligado aos processos de cultivo agrícola e criação de animais, extrativismo e toda a cadeia de produção de alimentos.

Dado que a produção e o consumo de víveres precisam ser mais críticos e responsáveis, Emily Ballantine-Brodie (2018) questiona como os designers podem planejar novos sistemas alimentares, que se ocupem de demandas socioeconômicas e culturais, e ao mesmo tempo contemplem a saúde humana e do planeta. E como o design pode desenhar relações mais humanas, alternativas para esse sistema alimentar de escala industrial. A figura a seguir mapeia atores e ações fundamentais para a construção do sistema alimentar do amanhã, baseando-se na produção, processamento, distribuição e consumo locais. Esse modo de regionalizar o sistema alimentar fomenta o desenvolvimento da sociedade e economia locais, além de beneficiar o meio ambiente e promover relações humanas.

Um rápido olhar sobre os quatro pilares do Food Design mostra como Comida, Sociedade, Meio ambiente e Tecnologia são interdependentes, sendo quase impossível dissociar a existência de um elemento da existência do outro. Os quatro pilares apresentados serão retomados de maneira sistêmica no capítulo 3. Cadeias curtas de produção e consumo: do produtor ao consumidor pelas mãos do chef de cozinha.

17 "These are the four areas that Food Designers should investigate when designing anything related to food and eating, regardless of whether they are designing a dish, an event, a food service or a whole food system: every dish, every product, every event, and every food service is part of a system, and each food system sits on these four pillars. Each food system is made of elements from these four pillars, and within any Food Design project one should design aspects (or considering aspects) from each of these four pillars. 


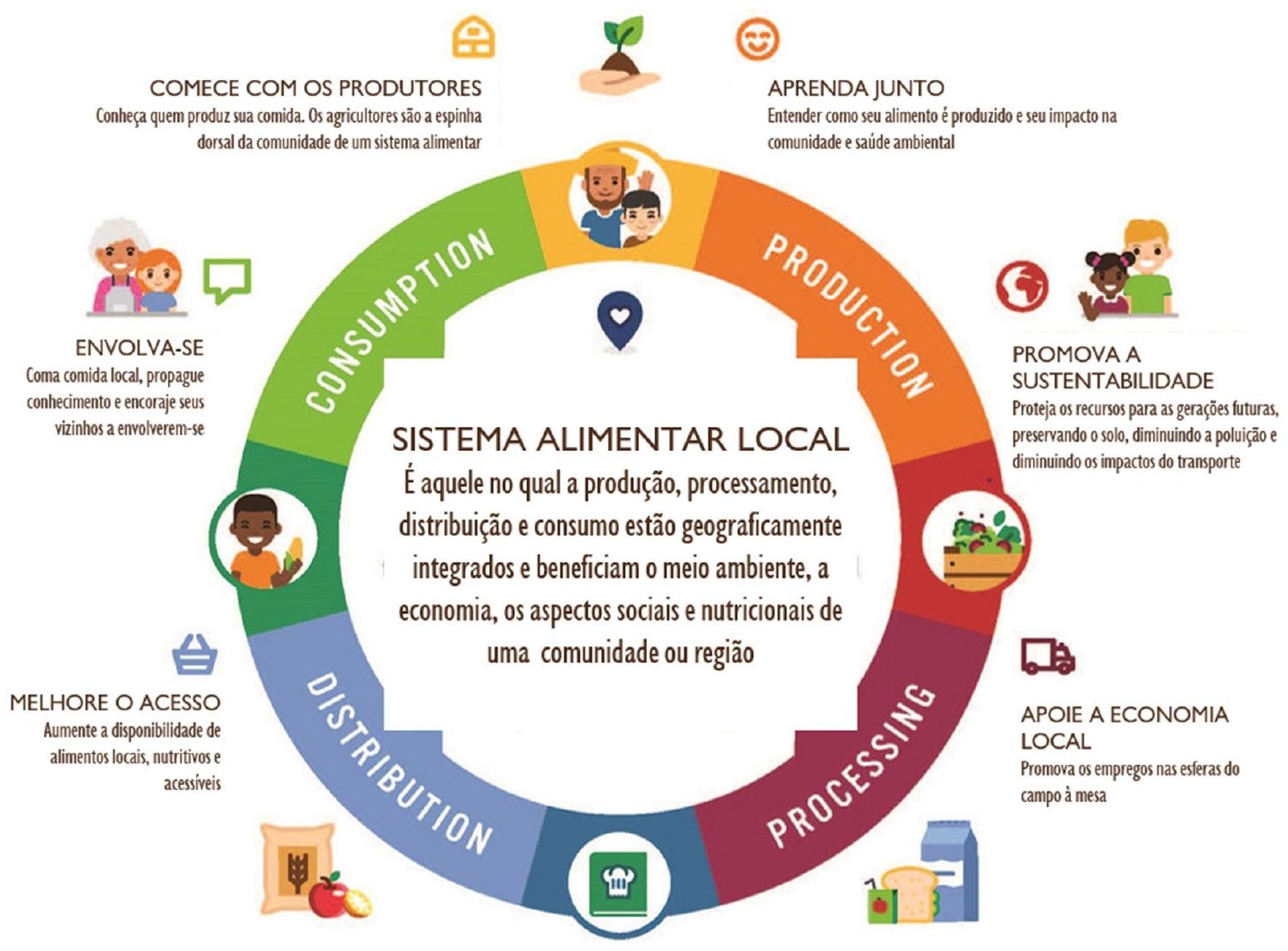

Figura 11. O sistema alimentar (Departamento de Agricultura dos Estados Unidos, 2019).

\subsubsection{Comida}

"Nenhuma outra atividade será tão permanente na história humana." (Cascudo, 2011)

A alimentação é uma necessidade básica de sobrevivência, e, portanto, estruturante para a organização e desenvolvimento da sociedade, como se vê ao longo da história com vestígios de utensílios, ritualizações, etiqueta, e Câmara Cascudo ilustra essa afirmação com uma frase de Delavigne: "Tudo se arranja durante o jantar nesse século em que estamos. É através dos jantares que se governam os homens." 18 (Cascudo, 2011, p.36).

Tema de interesse das áreas de saúde, agronomia, engenharias e ciências sociais, sem esquecer da arte e design, a alimentação protagonizou questões éticas

18 "Tout s'arrange en dînant dans le siècle où nous sommes, et c'est par de diners qu 'on gouverne les hommes." 
e estéticas, crises, escândalos e ativismos em todos os campos. Carolyn Steel, em sua fala no Terra Madre 2020, salientou que "comida é essa força, que molda nossas vidas de diversas maneiras, e que muitas vezes não percebemos." 19

Nos anos 1970 a Sociologia se debruça com um novo olhar para o ato alimentar, e teorizam sobre cultura alimentar, tabus, práticas sociais e processos civilizadores através da alimentação, bem como a distinção social através do gosto (Poulain, 2006; Canesqui \& Garcia, 2005). As transformações sociais advindas do pós-guerra modificaram as necessidades alimentares no início do século $X X$, e a mecanização da produção alimentar aliada à adequação das indústrias trouxeram rápidas respostas à essas novas demandas (Poulain 2006), alterando a cultura alimentar, principalmente nos centros urbanos.

A massificação dessa cultura através da globalização dos mercados, a homogeneização do gosto, trouxeram antinomias como uma pretensa sensação de acesso a maior diversidade alimentar, enquanto desterritorializavam, desconectando a comida de suas origens e diminuindo a biodiversidade. Além disso, a vida útil desses produtos precisava se adequar às novas distâncias percorridas e atender à normas sanitárias mais abrangentes, motivando um processamento mais industrial dos alimentos (Canesqui \& Garcia, 2005).

Esse cenário levou ao surgimento de movimentos de revalorização do regional e local na década de 1980, com os produtos reconhecidos por sua indicação geográfica (AOC Appellatioin d'origine controllée ou DOC Denominação de origem controlada) e a Nouvelle Cuisine francesa, tendo a alta gastronomia como palco para os produtos locais; e subsequentes ações em prol das cozinhas étnicas e patrimonialização da alimentação - alimentos, receitas, utensílios, técnicas (Poulain, 2006).

Entretanto, Fischler e Poulain defendem a importância da internacionalização e acessibilidade aos ingredientes, entendendo que as culturas e tradições não são estáticas, vão se modificando e se ressignificando, como os emblemáticos exemplos do tomate na cozinha italiana, ou a batata na cultura europeia como um todo.

Ao tratar dessa inclusão cultural pela alimentação, Fischler diz que o alimento "entra no corpo do comedor, torna-se o próprio comedor, participando física e simbolicamente da manutenção de sua integridade e da construção de sua

\footnotetext{
19 "Food is this force, shaping our lives in many ways, but often in ways that we can't see".
} 
identidade" Poulain, 2006, p.53), reforçando a célebre frase do gastrônomo Brillat Savarin "diga-me o que você come: eu direi o que você é" ${ }^{20}$ (Barber, 2015 a, p.16).

Na década de '90 em diante há uma multiplicação dos discursos sobre alimentação, o paradoxo do onívoro exposto por Fischler em 1990 trata justamente dos dilemas encontrados pelos humanos ao se alimentar; quando contrapõe alimentos que podem/devem ser comidos e alimentos proibidos. Entram em cena enfoques com viés médico, nutricional, estético, dietético, político, espiritual, estatal (políticas públicas), movimentos antiglobalização fortemente ligados a indagações éticas, e uma profusão de dilemas alimentares.

Com a crescente preocupação da saúde planetária como um todo, em 2010, a FAO introduziu o conceito de "dietas sustentáveis", definidas como:

"dietas com baixo impacto ambiental que contribuem para a segurança alimentar e nutricional e para a vida saudável das gerações presentes e futuras. As dietas sustentáveis protegem e respeitam biodiversidade e ecossistemas, são culturalmente aceitáveis, acessíveis, economicamente justas, nutricionalmente adequadas, seguras e saudáveis; enquanto otimizam os recursos naturais e humanos." (FAO, 2010).

Com esse conceito, são colocadas em xeque muitas práticas alimentares adquiridas nas últimas duas gerações, processos rurais pouco sustentáveis, que mensuram produtividade pela quantidade em detrimento da qualidade, e pouco zelo pela saúde do planeta, e cada vez mais danos à saúde humana provocados pela carência ou excesso advindos da alimentação (FAO, 2010).

O sistema alimentar, tanto de produção quanto de pós-produção, com impacto significativo na degradação do planeta, deve ser analisado como um todo ao se planejar cenários futuros, tanto do tipo de comida que se planeja oferecer, quanto do seu modo de produção. De um lado, surgem paradigmas de obesidade e desnutrição, com números impressionantes de 2.1 bilhões de pessoas com sobrepeso ou obesas, enquanto quase 800 milhões de pessoas passam fome, e levantamentos de que 1.3 bilhões de toneladas de alimentos perfeitamente próprios para o consumo são desperdiçados ao ano (Willett, Rockström, Loken et al., 2019). Quando há, ao que tudo indica, mais comida do que é necessário no planeta, pesa a afirmação feita por Dr. Rajiv Shah, presidente da Rockefeller Foundation (WFP, 2020): "a fome é o fracasso moral do mundo moderno." 21

\footnotetext{
20 "Tell me what you eat: I will tell you who you are."

21 "Hunger is the moral failure of the modern world."
} 
Por outro lado, questões éticas como bem-estar animal, condições de trabalho, melhoramento genético surgem nas pautas. A transformação da lavoura de alimentos em commodity, combustível e ração animal - apenas 47\% da produção das lavouras são dedicadas à alimentação humana (Loken et al., 2019) é outro ponto relevante, apontado por Magdoff (2012). O autor aborda como animais e grãos são tratados como mercadoria sem apreço, sem valor relacional, tidos apenas como matéria prima base para a indústria.

Dra. Elizabeth Kimani-Murage enfatizou ainda a perspectiva de justiça humanitária dessa questão durante o webinar Reimagining Foodsystems (WFP, 2020) quando afirmou que "o alimento foi tão comoditificado que as pessoas que o produzem passam fome" 22 .

Depois de sucessivas etapas de processamento, embalagem e revenda, o produto chega ao consumidor final tão descolado de seu estado natural, que não resta nenhuma conexão entre o campo e a mesa. Como afirmou Pollan (2008), as pessoas nunca foram tão interessadas por comida, e ao mesmo tempo nunca estiveram tão desatentas com o que estão comendo.

O contra movimento da industrialização em massa traz novos posicionamentos e preocupações com o as demandas da alimentação em escala, e iniciativas transnacionais como o Slow Food, Via Campesina, entre outros, começam a surgir já no fim da década de 1990. Esses movimentos pregam a necessidade de se reconectar à origem e métodos de produção dos alimentos, enaltecer o local, os cultivos e as culturas regionais, com uma visão mais humanizada, que valorize igualmente o sistema alimentar, a natureza e as pessoas (Petrini, 2001).

Carlo Petrini é contundente ao dizer que a natureza foi colocada à serviço do homem com uma produção que pretere a qualidade pelo potencial de comercialização, em que se reduz a biodiversidade, se despreza as propriedades organolépticas dos produtos em função de uma conveniente padronização, e que, tudo isso, ainda é feito a altíssimos custos de degradação ambiental. Ele finaliza: "Em lugar de acabar com o drama da fome no mundo, instalamos um sistema global desrespeitoso do trabalho de milhares de pessoas e socialmente criminoso" (Petrini, 2006).

22 "food has been so commodified that people who produce it are actually hungy." 
Está clara a necessidade interagir com os ciclos naturais, mudar as práticas, e deixar de olhar para a natureza como provedora infinita. A sazonalidade, a localidade precisam ser respeitadas para que o custo das escolhas alimentares não recaia sobre o equilíbrio do planeta. A decisão do que cozinhar e comer muda o mundo.

\subsubsection{Sociedade}

Em seu livro Sociologias da Alimentação, 2006, Poulain trata da abordagem teórica dos estudos da sociologia, que na década de 1960 passou a ver a alimentação como objeto sociológico; contrapondo as correntes clássicas com um novo olhar, multidisciplinar. No pensamento mais clássico, as práticas alimentares não são foco de interesse, vistas pela lente da antropologia e geralmente ligadas a temáticas religiosas ou técnicas de aquisição alimentar, sem referências às técnicas culinárias ou rituais cotidianos. Na corrente moderna, levam-se em conta as características sociais ligadas ao comer, sob uma perspectiva de que a cultura de uma época e seu povo têm influência determinante nas práticas e escolhas alimentares. Ao incorporar o alimento, o homem também incorpora, e é incorporado, pela cultura que permeia esse alimento.

Para ilustrar esse raciocínio, Poulain traz que hábitos alimentares são

"maneiras segundo as quais os indivíduos ou os grupos de indivíduos, em resposta às pressões sociais e culturais, escolhem, consomem e disponibilizam certas porções dos produtos alimentares existentes" (Poulain, 2006, p.160).

O autor segue trazendo perspectivas e sociólogos para o debate, e se apoia em Lévi-Strauss para ressaltar uma característica que distingue a sociedade humana de todos os outros primatas, que é a prática de cozinhar, de alguma maneira, seus alimentos. Diferentemente de apenas estocar, como notadamente insetos como as formigas fazem, o homem salga, faz conservas, defuma e cozinha seus alimentos de forma universal; "assim como não existe sociedade humana sem linguagem, não existe nenhuma que, de uma maneira ou de outra, deixa de cozinhar alguns de seus alimentos" (Poulain, 2006, p.163).

No final da década de 1970, Fischler traz o debate da evolução das maneiras de comer, e aponta três grandes momentos de mudança dos padrões de consumo na sociedade: a superabundância alimentar no Ocidente, trazida pela superação da fome com a Revolução Verde; a redução dos controles sociais (acesso ao alimento, afrouxamento das regras do que e como se come) e uma multiplicação dos discursos sobre alimentação (higienistas, identitárias, hedonistas, estéticas, políticas, 
espirituais etc.). Ao mesmo tempo que em há uma libertação, esse afrouxamento de regras traz uma angústia muito grande ao consumidor, que muitas vezes não sabe o que escolher para sua refeição, delegando, por vezes, a tarefa aos profissionais da alimentação, personificados pelos chefs de cozinha.

Ainda sobre as relações sociais da alimentação, Bourdieu (2008) trata o gosto/paladar como fruto do contexto social, algo cognitivo, que pode ser educado. Ele reflete o contexto social em que o indivíduo está inserido, ao que está habituado a comer. O gosto e o consumo são formas de distinção social, que exprimem, através da escolha, uma cultura.

"O comedor humano está submetido a algumas regras biológicas [...] mas as escolhas dos produtos nos quais ele encontra seus nutrientes, a maneira de cozinhar, de comer, mais globalmente os gostos e a ausência de gostos, são muito amplamente determinados por fatores sociais" (Poulain, 2006, p.245).

Embora o fato de ser onívoro possibilite aos indivíduos humanos comerem "de tudo", o contexto social, a cultura, são preponderantes nas escolhas. conjunto de rituais que cercam o ato alimentar são definidos de acordo com seu entorno social, e variam desde a definição do que é uma refeição até as rotinas diárias, os utensílios e regras. As tradições socioculturais influenciam o desejo e o preparo de itens em particular, e estão diretamente conectadas com status social, eventos festivos e religiosos (inclusive tabus). O sistema culinário, dentro desse cenário, é responsável por regular as escolhas, ou ao menos limitá-las, diminuindo as escolhas do comedor. As questões modernas da alimentação vêm justamente de um momento em que as regras culturais estão muito mais fluidas, as instituições menos sólidas, e as informações são tão intensas quanto efêmeras (Poulain, 2006).

Da década de 1970 em diante, a sociedade urbana, particularmente, observa uma curva crescente de sua população, diminuiç̧ão dos espaços (individuais, de trabalho e moradia, mas também de lazer, principalmente ao ar livre), consolidação de um estilo de vida sedentário, amplificada por pressões sociais e financeiras que movem o indivíduo a focar na produtividade, deixando de lado hábitos simples como o de cozinhar e comer em coletividade. O espaço antes ocupado pela mulher, no centro da vida doméstica, dá lugar a novos atores que decidem tanto as refeições domiciliares quanto fora do ambiente doméstico, que são influenciadas por fatores como indicações profissionais para as escolhas dos alimentos, oferta institucional (trabalho, escola) e decisões individuais (variedade de restaurantes e outros provedores de comida pronta para o consumo).

A urbanização proporciona desafios e oportunidades para os sistemas alimentares, e trazer inovações sociais nesse contexto depende das possíveis 
interações entre os atores de todas as esferas, sejam eles cidadãos, instituições, iniciativas pública ou privada, em um esforço coletivo para endereçar questões sociais que foram relegadas ou não alcançadas pelas estruturas existentes (Cipolla, 2012).

Em setembro de 2020, a ONU retomou a discussão dos Objetivos de Desenvolvimento Sustentável, lançando formalmente o compromisso dos 17 ODS, que devem ser implementados em todo mundo até 2030 (ONU, 2020). Mais da metade desses objetivos aborda diretamente a sustentabilidade e/ou alimentação, com grande foco nos ambientes urbanos. Isso implica em mudanças imediatas de estilo de vida nas cidades, dentre os quais merecem destaque os hábitos alimentares e de consumo. Agnes Kalibata (enviada especial da ONU) deixa a seguinte fala para o Foodsystems Summit 2021:

"Comida, que abastece nossos corpos e economia, perpassa todos os 17 ODSs. Se canalizarmos nossas energias para os sistemas alimentares, levantaremos muitas barreiras que impedem o desenvolvimento global e sustentável" 23 .

Os 17 ODS oferecem chances de inovação através do Food Design, mesmo que de maneira indireta. A alínea da produção e consumo responsável, por exemplo, é uma miríade de oportunidades, com bases no tripé da sustentabilidade, economia circular e design participativo ou co-design.

"Transformar os sistemas alimentares requer mudanças de comportamento de consumidores, produtores e distribuidores. Isso pode significar modificar normas sociais e práticas culturais para facilitar e tornar menos custoso para os atores envolvidos a possibilidade de tomar decisões visando estilos de vida mais sustentáveis." 24 (ONU, 2018, p.64).

A importância de se facilitar o acesso à alimentos frescos e in natura, reduzir o consumo de processados e ultra processados (crescente demanda do estilo de vida acelerado dos grandes centros), enxergar de forma crítica o marketing de alimentos industrializados estão na pauta das mudanças sociais (Foodsystems, 2020). Algumas práticas, herança dos movimentos de inserção feminina no mercado de trabalho e das novas constituições familiares que iniciaram após a segunda Guerra (Barber, 2015a) refletem-se nas prateleiras dos supermercados, e reverberam em um modo de vida que pretere a praticidade em detrimento da qualidade.

${ }^{23}$ Food, which fuels our bodies and our economies, underpins all 17 SDGs. By channelling energy into food systems, we lift barriers holding back global and sustainable development."

24 Transforming the food systems requires changes in behaviour by consumers, producers and distributors. That may require challenging social norms and cultural practices while making it easier and less costly for the relevant actors to make responsible decisions regarding sustainable lifestyles 


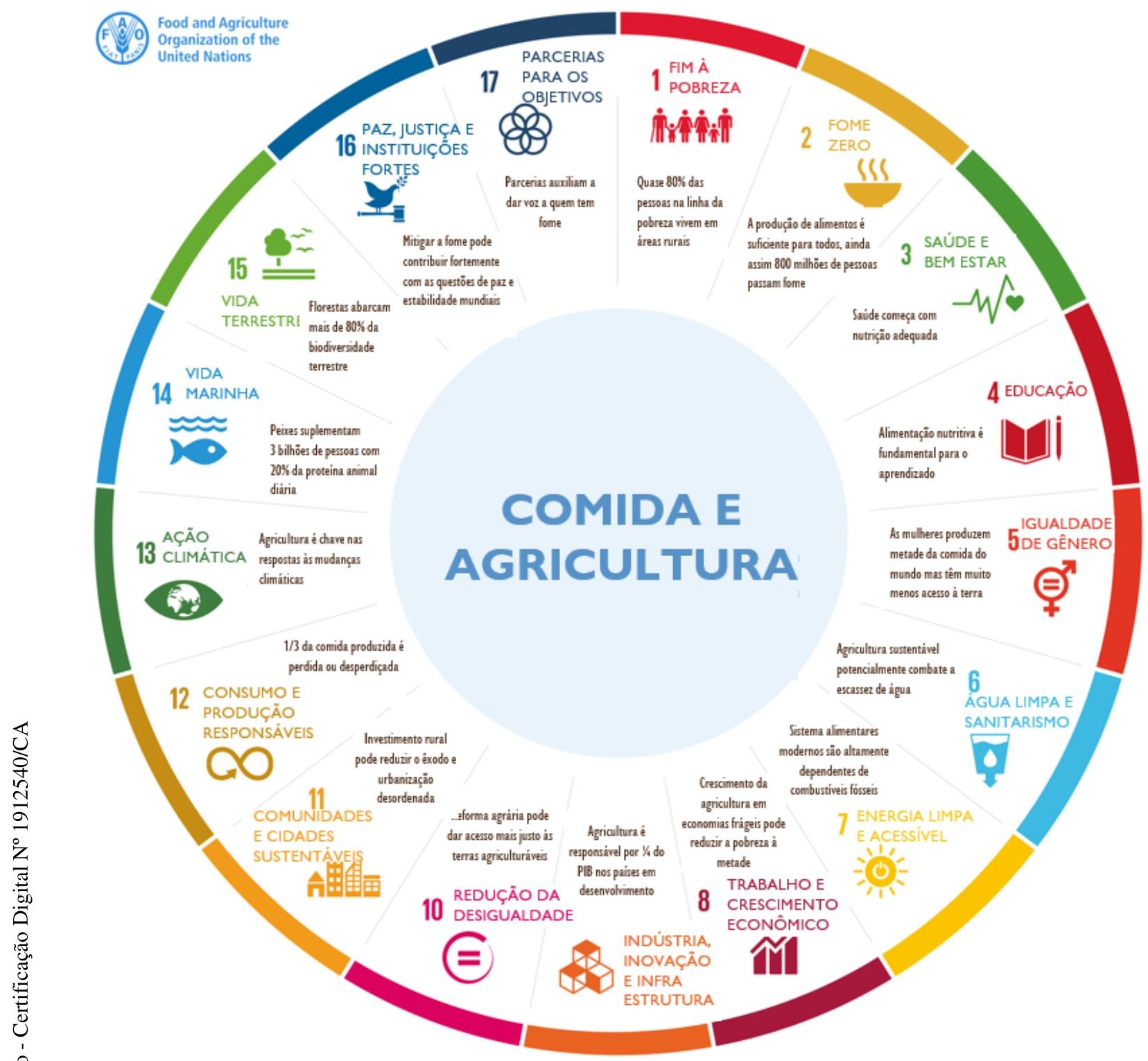

Figura 12. ODS e sua relação com Comida e Agricultura (FAO, 2020)

Uma amostra palpável, que retrata as mudanças na sociedade e muitas das implicações modernas relacionadas à escolha dos alimentos, são as prateleiras dos supermercados, livros, revistas, documentários e mídias digitais voltadas à escolha do que comer. Entre preocupações éticas e estéticas, os consumidores estão cada vez mais interessados no que comem. Marion Nestle aborda essa mudança de comportamento e cultura alimentar da sociedade em seu livro Food Politics: How the Food Industry Influences Nutrition and Health (2002), e vai mais fundo tratando do papel da indústria dos alimentos em financiar pesquisas e marketing para direcionar as tendências e modismos do consumo no mercado em seu livro Unsavory Truth, (2018).

Com o consumidor mais alerta, a estrutura da cadeia de consumo precisa se adaptar. Se a ingestão de alimentos industrializados atinge máximas históricas, o 
outro extremo também começa a despontar. Sistemas alimentares locais estão aos poucos se fortalecendo, com pequenos produtores fornecendo restaurantes pontuais e consumidores finais, redes de compra direta e CSAs (Comunidade que dá Suporte à Agricultura) cada vez mais acessíveis, e um número crescente de pessoas na contramão da aceleração moderna, valorizando as refeições feitas em casa, os processos artesanais e em pequena escala. Com isso, é enaltecido do mesmo modo o trabalho, o tempo dispendido na produção de alimentos de qualidade, e o consumidor se aproxima de quem produz seu alimento, do local de origem, dos métodos produtivos (Marsden et al., 2000).

Essa contracorrente de mudança no padrão social é igualmente abordada por Cipolla (2012), Meroni e Sangiorgi (2011) como um processo de inovação social, com soluções criadas por grupos ou comunidades que evidenciam demandas, nichos de mercado de produtos e serviços com potencial para abordar, e quiçá tratar, de maneira mais adequada às adversidades sociais, econômicos e ambientais mais atuais. A mudança da cultura alimentar é uma construção da sociedade, que delineia, com seus hábitos de consumo, o futuro dos mercados, da produção e dos atores envolvidos. Para Dan Barber, chef norte americano, "não se pode pensar em mudar partes do sistema (alimentar). Precisamos pensar em redesenhá-lo" 25 (Barber, 2015a, p.21). Os sistemas alimentares têm um papel fundamental na qualidade de vida da sociedade como um todo, assegurando que todas as partes sejam capazes de estar o mais saudáveis quanto possível. Para que isso ocorra, naturalmente, o sistema deve estar igualmente acessível e em equilíbrio, contribuindo para a promoção da saúde coletiva, igualdade de gênero, bem-estar laboral e animal.

Algumas dessas mudanças no padrão de consumo foram amplificadas com a pandemia do Novo Corona vírus no primeiro semestre de 2020, com significativo número de famílias em isolamento domiciliar, e a consequente necessidade de se cozinhar mais refeições em casa, reduzir a frequência das compras e maximizar o aproveitamento e reaproveitamento dos alimentos.

Se em um primeiro momento a corrida foi em estocar produtos industrializados e menos perecíveis, quando se compreendeu que o isolamento perduraria, o comércio local foi incentivado tanto para contribuir na manutenção das pequenas empresas quanto pelo iminente impacto das longas cadeias na

\footnotetext{
25 "We can't think about changing parts of our system. We need to think about redesigning the
} system." 
alimentação, que deixou à mostra as vulnerabilidades e desigualdades do sistema alimentar. Com isso revelaram-se não só os grandes equívocos na maneira em que é produzida e distribuída a comida, como também no impacto salutar causado pela má alimentação, fatores diretamente relacionados à propagação do COVID-19. No cenário de controle de fronteira e de movimento, perda massiva de empregos e a previsão do aumento do número de famintos no mundo de 135 milhões para 260 milhões, vem à tona a necessidade iminente de mudança, de encurtar as distâncias percorridas pela comida, de incentivar as redes independentes, a mudança de hábitos alimentares, e as vantagens de um sistema alimentar mais resiliente e sustentável (Pollan, 2020).

\subsubsection{Meio Ambiente e Sustentabilidade}

Pensar o design de qualquer produto ou sistema sem levar em conta aspectos da sustentabilidade econômica, social e ambiental não é mais uma escolha ou um objetivo específico, e sim a base de qualquer projeto de Design. Francesca Zampollo (2017) marca com firmeza a posição do designer, especificamente daquele que trabalha com alimentos (Food Designer), que precisa estar atento a todas as proposições relacionadas ao uso consciente dos recursos naturais, impactos ambientais, na sociedade, e princípios como transparência e equidade em todas as fases projetuais:

$\mathrm{Na}$ atual conjuntura, deveríamos desenhar apenas produtos e serviços que sejam sustentáveis em termos de desperdício de alimentos, mudanças nas organizações, mudanças de comportamento, materiais, agricultura, cadeias de abastecimento etc. Não é mais possível para os designers não pensarem no impacto ambiental dos materiais que eles escolhem" ${ }^{26}$ (Zampollo, 2016a).

Manzini (2008) aponta os designers como profissionais capazes de planejar soluções planetárias, com inovação nos modos de vida, nos valores da sociedade, e na mudança dos padrões de produção e consumo. Para isso, tanto Manzini (2014) quanto Parreira (2014) abordam a busca do equilíbrio entre crescimento econômico, proteção ambiental e condições sociais balanceadas. A cadeia agroalimentar é diretamente conectada à essas questões. O design sistêmico dessa cadeia deve

26 "At this day and age, we should only design products and services that are sustainable in terms of food waste, organizational changes, behavioral changes, materials, agriculture, supply chain, etc. It's not possible for Food Designers not to think on the environmental impact of the material they choose." 
contemplar aspectos qualitativos e quantitativos, ser criterioso no desenho da malha e na avaliação das variáveis.

Os sistemas alimentares ocupam quase $50 \%$ das terras habitáveis, e contribuem com quase $25 \%$ do total de emissões de gás de efeito estufa (Foodsystems, 2020). Os dados apresentados em 2020 pela ONU e FAO correlacionam fortemente a perspectiva ambiental e alimentar. As recomendações para garantir mesmo que sejam exíguas mudanças climáticas e minimizar a devastação ambiental incluem focar em inovação tecnológica, circularidade da economia, políticas públicas e de governança, comportamento (envolver as organizações sociais, academia, bancos de alimentos, chefs, notícias, informação) e educação, para elevar o grau de conhecimento sobre o assunto. Saber como e por quem a comida é produzida, a que processos é submetida é o primeiro passo para respeitar todos os atores envolvidos. Reconectar as pessoas com a origem dos alimentos, a terra, os produtos locais, é o primeiro passo na formação de um modelo mais equilibrado de produção e consumo.

Nos diversos relatórios de impacto ambiental, a produção e o consumo de alimentos figuram com destaque. A indústria alimentícia é o maior segmento econômico mundial, e resvala em todos os setores, da saúde privada aos cofres públicos, deteriorando o bem-estar das pessoas e natureza (Pollan, 2016). Os prejuízos ambientais são igualmente marcantes, e representam mais de 30\% do consumo total de energia, contribuindo para quase um quarto das emissões causadoras do efeito estufa, conforme detalhado na Figura 13. "A contribuiç̧ão do sistema alimentar para o consumo de energia e emissões."

As perdas que ocorrem entre a lavoura e os pontos de venda, além de agravar a insegurança alimentar, principalmente nos países em desenvolvimento, causam um desgaste redundante no solo e na rede hídrica. Já o desperdício promovido no outro extremo da cadeia, com o consumidor intermediário e final, é um dos grandes propulsores das emissões carbônicas (FAO, 2020). Nessa ponta, o desperdício acontece de maneira rotineira e por vezes imperceptível, quando há, por exemplo, compra desmesurada ou mal programada, critérios estéticos ou sanitários excessivos, longas distâncias entre o campo e a mesa. Afora extenuar os recursos naturais, o desperdício de alimentos desencadeia perdas financeiras, de tempo e força de trabalho, recursos valiosos despendidos em vão. 


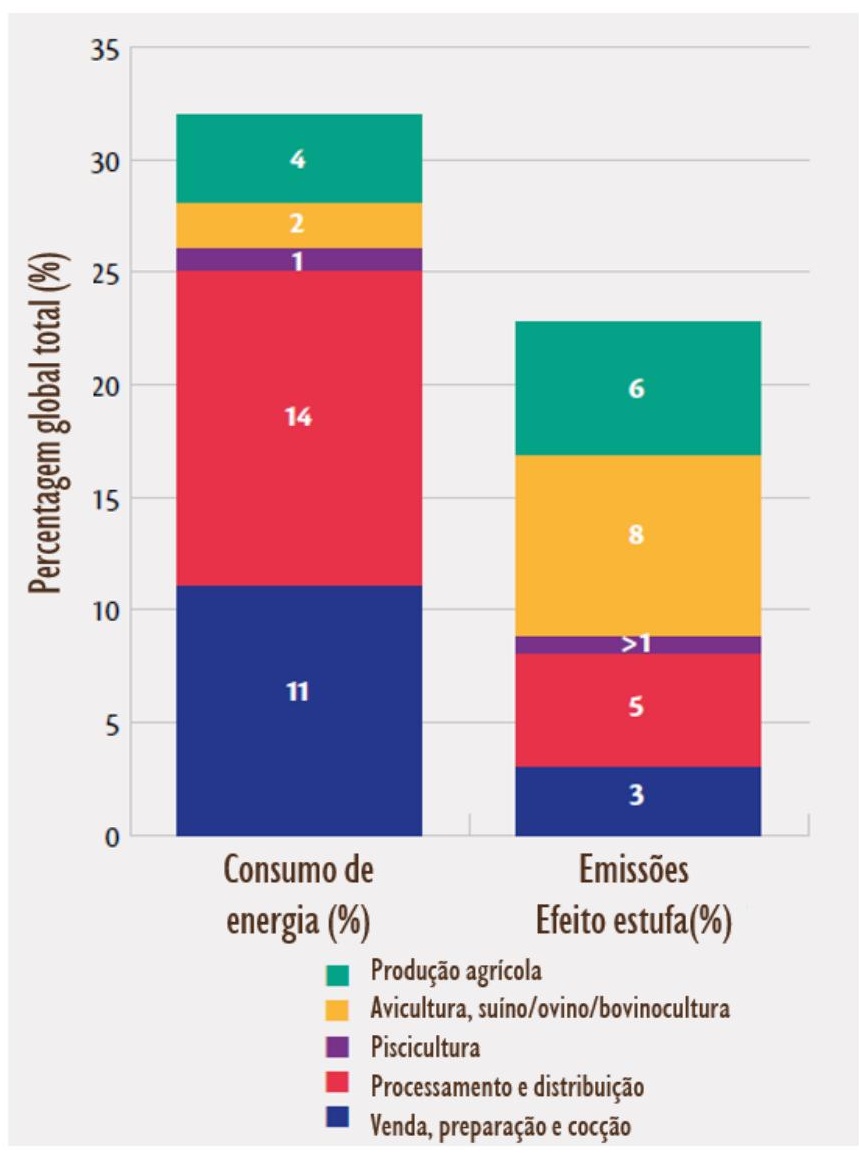

Figura 13. A contribuição do sistema alimentar para o consumo de energia e emissões (Global Food Policy Report, 2016).

Imagens de plantações morrendo no pé ou colheitas sendo jogadas em aterros ou até mesmo na beira da estrada enquanto quase 800 milhões de pessoas no mundo passam fome são tanto absurdas quanto cruéis. Histórias de agricultores que simplesmente não tem meios de fazer sua produção chegar ao consumidor final se acumulam, assim como as perdas de alimento, trabalho, recursos naturais e financeiros. Durante as discussões em torno do primeiro Dia Mundial da Conscientização do Desperdício de alimentos, o diretor geral da FAO, QU Dongyu afirmou: "Desperdiçar alimentos significa desperdiçar recursos naturais escassos, aumentar os impactos das mudanças climáticas e perder a oportunidade de alimentar uma população crescente no futuro". As discussões em torno do tema deixam claro o papel da indústria alimentícia no impacto ambiental, e a necessidade iminente de redesenhar o sistema alimentar, as cadeias, o consumo. A atuação de cada elo dessa cadeia é fundamental, seja em inovações tecnológicas no campo e no acondicionamento, seja na logística de abastecimento, seja na mudança dos hábitos dos consumidores (FAO, 2020). 


\subsubsection{Tecnologia}

A primeira e mais antiga forma de relação entre design e comida é tão antiga quanto a necessidade de comer, com a fabricação de utensílios para facilitar o consumo imediato, como facas (inicialmente lâminas), colheres e recipientes; e para o cultivo, transporte, preparo e conservação, como arados, enxadas, potes, panelas. São objetos marcantes de todas as civilizações humanas, utilizados inclusive como métrica de desenvolvimento social. (Margolin, 2013). A história da civilização é indissociável da história da alimentação.

De um salto das cavernas para a Revolução Verde (décadas de 1940 a 1970), quando ficou evidente a dependência humana das culturas de grãos (trigo, arroz, milho e soja), a tecnologia protagonizou o domínio sobre a natureza como talvez nunca tenha feito. O novo modo de produção, a agroindústria, passou a depender de fertilizantes químicos, pesticidas e irrigação. A chamada Segunda Revolução Verde, com base na engenharia genética, seguiu selecionando as espécies em função de sua resistência aos aditivos químicos e seu rendimento, e o mundo aumentando cada vez mais suas áreas de monocultura (Piesse, 2017). Para alimentar a população mundial em franco crescimento, a produção de alimentos aumentou tanto, e de maneira tão abrupta, que colocou o planeta no limite. Certamente a espécie humana não estaria chegando aos 10 bilhões de indivíduos em 2050. A manipulação da natureza deixou bilhões de pessoas dependentes de nitrogênio sintético (entre outros compostos químicos manipulados), e efeitos devastadores de erosão e morte dos solos, aquecimento global, poluição do ar e águas (Barber, 2015a).

O cenário atual não poderia ser diferente. Com a manipulação genética pelo rendimento e adequação industrial, os números da perda da biodiversidade são impactantes. Essas espécies são caracteristicamente menos resilientes, e colocam em risco toda forma de cultura monovarietal, que por sua vez deixa em perigo a população de dela depende para se alimentar. Segundo Petrini (2008), 75\% da biodiversidade alimentar europeia se perdeu desde 1900, enquanto nos Estados Unidos esse percentual é de $93 \%$, com a extinção de 30 mil variedades vegetais no último século. No Brasil, 10 itens compõem $45 \%$ do básico do consumo cotidiano, com arroz, feijão e pão de farinha branca liderando a lista (O Joio e o Trigo, 2020), conforme ilustra a Figura 14 . Monotonia na dieta brasileira. O homem moderno está tão distante dos processos produtivos tradicionais, a ponto de não ser mais capaz de plantar e produzir sua própria subsistência. 
Petrini, como Barber, ao expor seu raciocínio, questionam se o homem dominou a agricultura ou se foi dominado por ela. O paradoxo da tecnologia aplicada à alimentação é justamente quando se observa que há muita atenção dispensada pela grande indústria. Recentemente viu-se a fusão de expressivas corporações de ambos os setores, que atualmente controlam praticamente todo o mercado de alimentação e saúde através de sementes, biomanipulação, insumos agrícolas e medicamentos: BASF, Bayer/Monsanto, ChemChina/Syngenta e Dow/Dupont são alguns exemplos das fusões dos laboratórios de alimentos e remédios (Xavier, 2019). “As pessoas são alimentadas pela indústria da comida, que não dá nenhuma atenção à saúde - e são tratadas pela indústria da saúde, que não dá atenção à alimentação." ${ }^{27}$ (Deakin, 2019).

\section{Monotonia na dieta brasileira:}

de Norte a Sul, 10 produtos concentram mais de $\mathbf{4 5 \%}$ do consumo alimentar
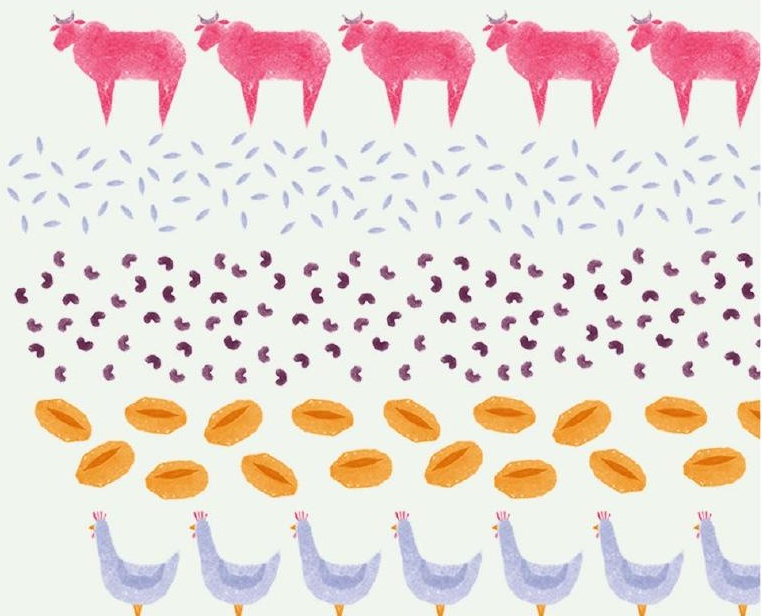

Figura 14 . "Monotonia na dieta brasileira" (O Joio e o Trigo, 2020).

Está claro que a tecnologia pode ser bem utilizada para benefício da sociedade, e sem prejuízo para a natureza. Os avanços da agricultura 4.0 começam a olhar para demanda e valor nas cadeias de produção e consumo dos alimentos, tendo a tecnologia não apenas como propulsora da quantidade, mas também se adequando às necessidades dos consumidores. Os avanços tecnológicos podem ser vistos em ferramentas de manipulação para as lavouras, conhecimento e práticas biodinâmicas, mapeamento e sensores que amplificam o aproveitamento dos recursos naturais, auxiliando, até, na prevenção de perdas (Clerq, Vats \& Biel, 2018). Os limites de crescimento podem ser ultrapassados, mas nunca desrespeitados.

27 "People are fed by the food industry, which pays no attention to health - and are treated by the health industry, which pays no attention to food. 
Ainda nas conexões entre design e alimentação, é notável a presença da tecnologia para atrelar os atores do sistema alimentar e fortalecer as redes. Conforme destacou Ariel Molina durante o Seminário: Territórios e sistemas agroalimentares sustentáveis:

"os grupos são formados a partir de coesão social na sua vivência em grupo [...] e a capacidade de atuação em rede tem potencializado essa comunicação digital. O que precisamos fazer é descobrir as outras pessoas que estão do nosso lado, trabalhando com as mesmas atividades [...], assim teremos forças para avançar com esses novos movimentos, novas relações entre campo e cidade." (Comida de Verdade, 2020).

A intensificação no uso dos canais digitais durante o isolamento social de 2020 contribuiu muito para a acessibilidade do consumidor final a produtos que eram quase que exclusivos dos restaurantes e hotéis, como maneira dos pequenos produtores manterem sua renda e escoamento da produção. Essa disseminação criou oportunidade para o surgimento de aplicativos e plataformas de e-commerce, e construiu desta forma novos relacionamentos, propiciados pela conveniência da compra on-line com entrega programada.

As diferentes mídias digitais, cada vez mais acessíveis, foram um trampolim para que muitos cozinheiros, ou novos chefs celebridades, saltassem para a frente do palco, e compartilhassem sua rotina, desejos e ambições, aproximando esse ator do público. Com isso, vem à tona situações relevantes e pouco conhecidas como a rotina da cozinha, o tratamento dos insumos, a produção. As redes sociais, particularmente, tornaram-se um ambiente de diálogo e aproximação, que vê no engajamento e interação dos usuários um processo de iteração e constante aprimoramento. A jornalista e Food Designer Érica Araium aborda as tendências da gastronomia digital, como plataformas de e-commerce, economia circular, inteligência artificial, realidade aumentada, entre outras, que já vinham despontando e foram impulsionadas pela pandemia do COVID-19. Ela também menciona uma crescente força do "home everything", em um cenário em que as pessoas voltaram a passar mais tempo em casa, e os serviços de alimentação são diretamente abalados, com demandas para "chef em casa", entrega de refeições cada vez mais personalizadas, e um retorno ao cozinhar em casa, embora cada vez mais sofisticado e facilitado pela miríade de serviços relacionados. Enquanto de um lado a tecnologia aproxima os restaurantes e chefs do consumidor que está em casa, por outro lado ela possibilita mais conforto e segurança nos estabelecimentos, com cardápios digitais, acessíveis por QR Code, conectados ao sistema do restaurante ou bar, permitindo, em situações limites, que o pedido seja feito, até customizado, sem a interação com um atendente (Araium, 2020). 


\section{As cadeias curtas de produção e consumo: do produtor ao consumidor pelas mãos do chef de cozinha}

Antes de definir cadeias curtas de produção e consumo, é preciso situá-las no sistema alimentar. Os sistemas alimentares abrangem todas as pessoas e atividades relacionadas, de alguma maneira, da produção ao consumo dos alimentos, e engloba também tempo, processos e distâncias entre o início e o fim. Ou seja, são todas as etapas percorridas para manter as pessoas alimentadas. Eles podem ser globais ou locais, com cadeias longas ou curtas, comida in natura, minimamente ou ultra processada, e todas as possíveis variações entre esses termos.

Segundo a ONG Foodsystems, cadeia de consumo e produção de alimentos, ou cadeia de consumo, inclui todas as etapas da produção e deslocamento dos alimentos do campo ao prato. Entre elas, mas não restrito a, estão: produção agrícola, armazenamento e distribuição, processamento e empacotamento, varejo e marketing; agricultores, processadores/ beneficiadores, atacadistas, transportadores e revendedores, até chegar ao consumidor final. A distância geográfica entre o início e fim desse circuito, bem representado nos cenários urbano e rural, é um dos fatores mais relevantes ao se classificar a cadeia como longa ou curta, mas não é o único, como se verá adiante (Foodsystems, 2020).

Nessa cadeia alimentar, diversas ações acontecem paralela e simultaneamente, e interferem umas nas outras. O ambiente (espaço físico, aspectos humanos e culturais), a disponibilidade e acessibilidade (econômica, social), hábitos de consumo. Fatores externos marcantes como as mudanças climáticas, globalização (econômica, cultural), renda e urbanização fazem parte da gama de situações que afetam a o sistema como um todo, incluindo efeitos na saúde e nutrição (Parsons, Hawkes \& Wells, 2019. Global Panel, 2016).

O conceito atual de cadeias curtas de produção e consumo de alimentos (CCCA) surgiu no início dos anos 2000, como resultado de um debate mais amplo sobre Cadeias Alimentares Alternativas, Redes Alternativas de Alimentos ou Cadeias Alimentares Sustentáveis. Diferentes autores abordam tais estudos e conceitos, tendo o geógrafo e sociólogo Terry Marsden (2004) descrito como parte fundamental do processo da cadeia curta, que o produto chegue ao consumidor final com informações que lhe permitam saber onde (lugar), por quem (produtor) e de que forma (sistema de produção) seu alimento foi produzido. Sob sua ótica, devem ser considerados três tipos de relações: a proximidade espacial - produtos produzidos e distribuídos na região da produção; proximidade estendida - produtos 
comercializados fora de sua região de produção, mas carregando valores, significados e informações locais; e proximidade física face a face, como ocorre nas feiras livres.

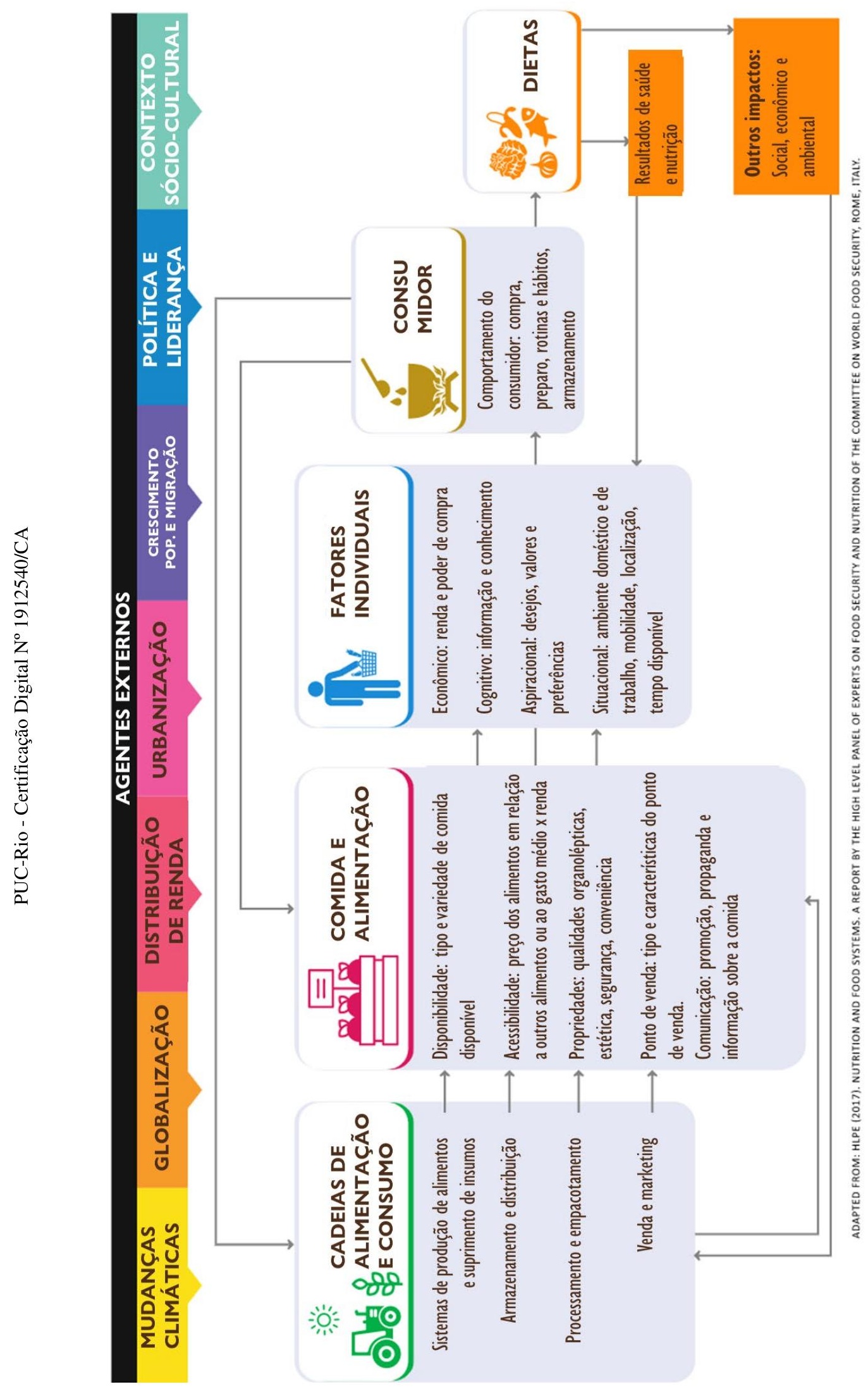

Figura 15 . Sistemas alimentares (Foodsystems, 2020) 
Marsden (2004) discorre ainda sobre as dimensões socioculturais, focando na importância do vínculo com o local, no desenvolvimento de uma relação entre produtor e consumidor, em que se considera preço justo e qualidade, e o restabelecimento da conexão do consumidor com o produto alimentar e sua origem.

As cadeias curtas de produção e consumo de alimentos, com definição e aplicação em debate surgindo em torno dos anos 2000 (Goodman \& Goodman, 2009; Ilbery \& Maye, 2005; Roep \& Wiskerke, 2006) têm por definição venda direta para o consumidor final (aceitando que haja, se necessário, um ou dois intermediários para venda indireta), e englobam uma variedade de modelos produtivos com contato direto entre as duas pontas da rede, o respeito pelo insumo, pelo trabalhador e pelo consumidor. Sob esse leque, estão os CSAs (Comunidades que Sustentam a Agricultura, do inglês Community supported agriculture), as cooperativas e redes de agricultura familiar (on-line e físicas), os modelos de agricultura urbana/peri urbana e as feiras do produtor (Azevedo et al, 2015).

Mesmo com pequenas oscilações conceituais entre os citados autores, as características centrais mais recorrentes nas definições de CCCA tratam da relação de cooperação entre produtores e consumidores, falam de valores como a sustentabilidade, mercados e identidade locais e estabelecem as premissas básicas das CCCAs, em que se privilegiam as relações estabelecidas entre produtor e consumidor final, se enaltece a rastreabilidade, qualidade, diversidade e origem dos produtos, e se valorizam as condições socioeconômicas do produtor. Esse modelo de cultivo tende a privilegiar produtos orgânicos e sazonais, com menores distâncias percorridas, menor impacto no solo, e menor índice de perdas no escoamento da produção.

Não há uma definição assertiva sobre que extensão pode ser chamada de curta nesse contexto, sendo levados em consideração conceitos mais abrangentes, como local e arrabalde geográfico, fisicamente próximo. Essa cercania é representada, de modo análogo, para a distância social, com a ausência de intermediários, sempre que possível, entre o consumidor e o produtor, e, se essa presença for necessária, que seja para melhorar essa conexão. O vínculo entre os atores se dá pela comunicação de valores além dos qualitativos do produto em si (organolépticos, nutricionais, estéticos), bem como éticos, e seus impactos no território (Marsden et al., 2000). 


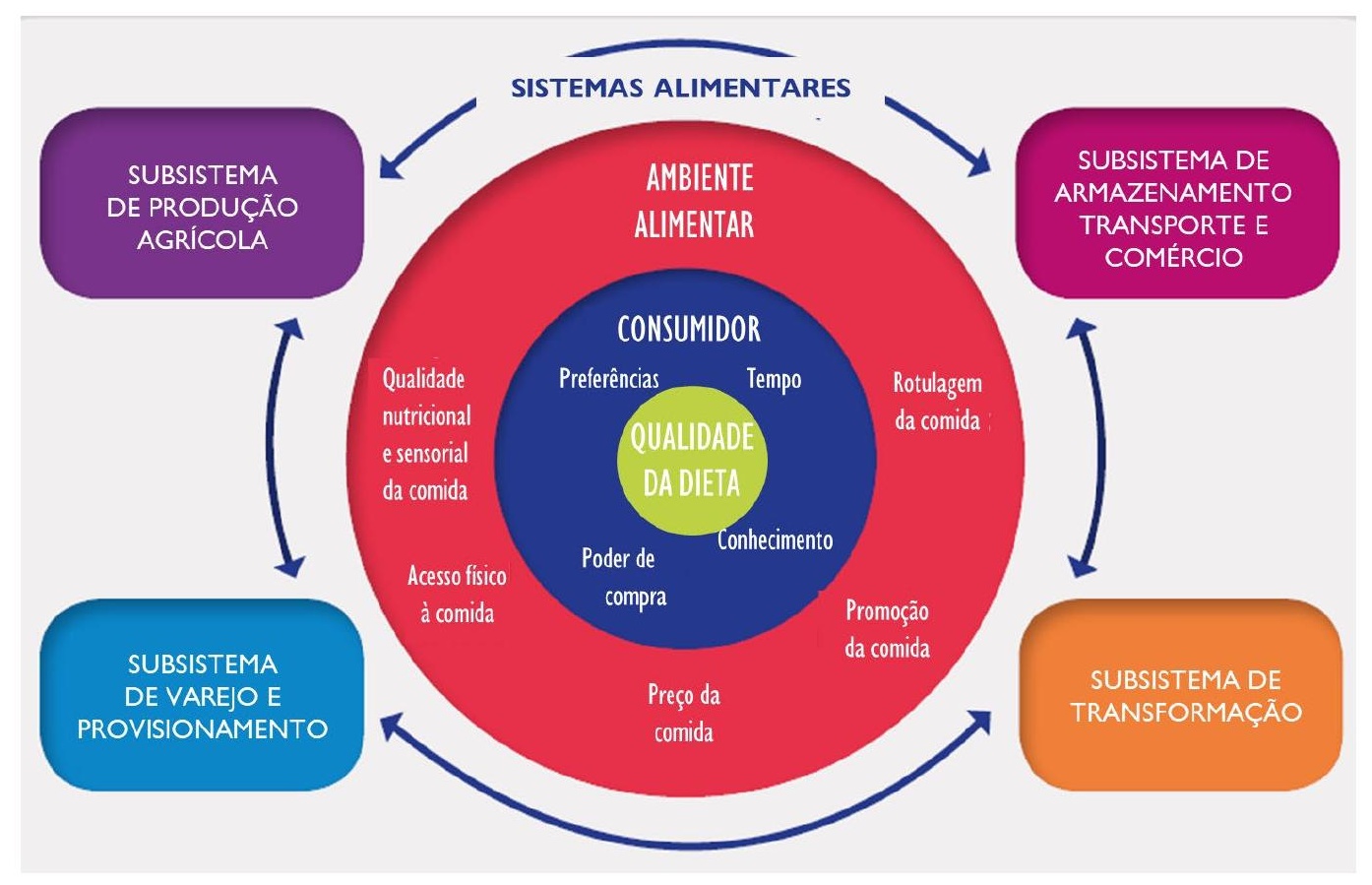

Figura 16 . Sistemas Alimentares (Haddad et al., 2016).

Acerca dos últimos tópicos, Ferrari (2011) trata da recontextualização e requalificação do alimento, com a possibilidade de julgamento de valor pelo consumidor e possibilidade e reconquista do controle de venda por parte do produtor. Além das relações mercadológicas, para Ferrari as cadeias curtas possibilitam abreviar as distâncias percorridas pelos alimentos até o consumidor final, possibilitam um laço social e de confiança entre produtor e consumidor, e fortalecem a economia local. O autor alega ainda que

"as cadeias agroalimentares curtas parecem representar uma dimensão importante nos novos padrões de desenvolvimento rural emergentes. Através delas estabelecemse novos padrões de consumo agroalimentares e uma maior conexão entre produtores e consumidores" (Ferrari, 2011, p. 92).

Quando se valoriza a origem, entram em cena questões fundamentais como agrobiodiversidade, impacto ambiental, terroir, soberania alimentar, valor agregado e autonomia econômica. Os padrões a seguir não são aqueles ditados pelos valores e tempo do mercado, e sim pela natureza. Quanto mais próxima a relação entre produtor e consumidor, mais nítidas se tornam as relações de custo e valor, culminando em empoderamento e melhoria na autoestima dos agricultores. Esse desenvolvimento relacional é visível no entendimento de qualidade, que abarca igualmente noções de localidade, pertencimento e impacto ambiental (Feagan, 2007; Galli \& Brunori, 2013).

É muito importante ter em mente que o termo "curtas" se refere não só às distâncias físicas, mas também ao abismo econômico, social e cultural que 
normalmente se vê entre quem compra e quem faz. A relação estabelecida é, nesse caso, efetivamente de troca. O processo de compra volta a ser um intercâmbio de experiências e saberes. A proximidade física da fonte de alimentos tem impacto direto no preço (minimiza os atravessadores, o gasto de combustível, as perdas pelo excesso de manuseio e tempo) e na qualidade (frescor, conservantes, sazonalidade, propriedades nutricionais); além de estimular a economia local (Schmidt, 2001).

As CCCAs, potenciais conectoras de produtores e consumidores, atuam da mesma forma nos processos colaborativos intra e inter agricultores, cooperativas, beneficiadores e consumidores de alimentos. Assim, elas incrementam ou geram valor agregado aos produtos e desenvolvem potenciais com benefícios mútuos. É dessa associação de interesses que podem surgir novos produtos, facilitar o acesso e distribuição dos alimentos, fortalecer as redes e construir novos mercados (EIP-AGRI, 0219).

Na cidade do Rio de Janeiro começaram a surgir por volta de 2010 iniciativas para concretizar esses ideais. A regulamentação do Circuito de Feiras Orgânicas no Município (Rio de Janeiro, 2012), as feiras livres de pequenos produtores, redes de compras coletivas, pequenos estabelecimentos comerciais com revenda de produtos locais, e aos poucos, a conscientização dos consumidores vai tomando corpo. O objetivo em geral é facilitar o acesso e a comunicação entre produtores e consumidores, criando laços. Nas feiras em espaços públicos, essa troca acontece mais espontaneamente, permitindo aos produtores estabelecerem seus preços e escoarem sua produção diretamente, e com periodicidade pré-determinada. Um projeto carioca que alia a feira de rua ao comércio equitável, é a Junta Local, que propõe em seu site:

"A Junta Local acredita na transformação desse cenário ajuntando quem come e quem faz em novos espaços onde comunidade, campo e cozinha se encontram. Parte dessa revolução consiste na compra direta, eliminando intermediários, criando cadeias curtas e empoderando o pequeno produtor. Mas ela vai muito além disso. A revolução depende também da criação de novas práticas de distribuição e logística, comunicação e ocupação urbana. Juntos queremos uma revolução deliciosa para tornar mais acessível a comida boa, local e justa. [...] Queremos ocupar o espaço público de forma festiva em torno de um bem comum: a comida local e justa." (Junta Local, 2014).

Thiago Nasser, fundador da Junta Local, afirma:

"ao encurtar a cadeia alimentar e pensar em plataformas de baixo custo criamos as condições para que o acesso à comida boa se democratize. Colocamos o pequeno produtor no centro da cadeia para que o dinheiro circule na economia local e vá para o bolso de quem realmente faz. O preço é justo quando não se traduz em prejuízos para quem faz, nem em prejuízos para o meio-ambiente e a sociedade." (Junta Local, 2014). 
Outro projeto relevante, baseado no modelo de CSA, que vislumbra aproximar produtores rurais de restaurantes, é o A.ch.a, com suporte técnico da UFRRJ (Universidade Rural do Rio de Janeiro) e gestão da Cambucá Consultoria. Implementado em 2018, o projeto propõe a divisão dos riscos da produção de vegetais especiais, que não estão disponíveis no mercado, com financiamento coletivo de chefs e restaurantes, garantia de produção e venda para os envolvidos. A metodologia se baseia no estreitamento das relações entre restaurantes e agricultores, com confiança e empatia. A ideia é que esse relacionamento transborde as regras mercantis, e que os produtores sejam vistos como indivíduos, e não centrais de abastecimento (Xavier, 2019).

Em busca de aprimorar as novas relações de produção e consumo, aparecem conceitos de design que podem ser utilizados para abordar o mote das cadeias curtas de forma interessante, e com isso trazer soluções para muitas de suas ainda incipientes questões, como abordado por John Thackara (2005):

\begin{abstract}
"Autenticidade, contexto local e produção local são atributos cada vez mais desejáveis nas coisas que compramos e nos serviços que usamos. O local vende e, por esse motivo, é um poderoso antídoto para a expansão da mobilidade. Mas o design para melhorar a localidade é mais fácil de dizer do que fazer" (Thackara. 2005, p. 73).
\end{abstract}

Desenhar serviços, propor alternativas, conjecturar sistemas alimentares sustentáveis como objeto de estudo do Food System Design proposto por Zampollo (2016) é um exercício tão possível quanto necessário para os profissionais da área. O estudo realizado por Pacenti e Sangiorgi (2010), aponta claramente para as conexões entre Design de Serviço, sustentabilidade e inovação social, reforçando uma visão sistêmica que se consolida no campo do Design.

\title{
3.1 Produtor
}

\begin{abstract}
"À mesa, não raro, cozinheiros e comensais contemporâneos se esquecem do óbvio: consumir é esgotar. Devorar o mundo de forma leviana ou sã é definir a paisagem que as próximas gerações verão adiante" (Erica Araium, 2020).
\end{abstract}

Dentro dos sistemas alimentares sustentáveis e cadeias curtas de consumo e produção de alimentos, o primeiro ator abordado é o produtor, sendo a própria engrenagem que faz a roda girar. Não há uma definição única ou concisa para Pequeno Produtor Rural ou Agricultor Familiar, mas tanto a Embrapa (EMBRAPA, 2014) quanto excertos da legislação em vigor baseiam suas conceituações no 
tamanho e desempenho econômico da propriedade, sendo a condução do negócio, estritamente familiar, uma referência. No Brasil, desde 2006,

"para ser considerado agricultor familiar é preciso que a propriedade tenha, no máximo, quatro módulos fiscais (que varia conforme o município e a proximidade maior ou menor com as zonas urbana e rural), onde seja utilizada predominantemente mão de obra da própria família, assim como a base de sustentação da renda familiar tenha origem nas atividades econômicas vinculadas ao próprio empreendimento" (BRASIL, 2006)

De acordo com o MAPA - Ministério da Agricultura, Pecuária e Abastecimento (2017), essa definição abarca mais de 10 milhões de brasileiros, e embora ocupe menos de $25 \%$ das áreas de cultivo, a agricultura familiar e os pequenos produtores rurais, juntamente com assentamentos de reforma agrária e comunidades quilombolas, abastecem cerca de $70 \%$ do mercado interno, principalmente com aipim, feijão, leite, suínos, bovinos, aves e arroz.

A FAO estimava, em 2014, que 3/4 de toda comida do mundo vinha desse modelo de cultura, que ocupa uma parcela consideravelmente reduzida das terras cultiváveis, se comparado com a ocupação territorial do agronegócio. Esse modelo de produção, diretamente oposto ao modelo do pequeno produtor, tem a monocultura de um único gênero agrícola, como milho, soja ou trigo, voltada à alimentação humana (mercados interno e externo), ração de animais, combustível ou produtos para a indústria. Segundo a Embrapa (2017), dos 63 milhões de hectares ocupados pela agropecuária no Brasil, mais de 61 milhões são tomados pelo agronegócio (Santos \& Glass, 2018).

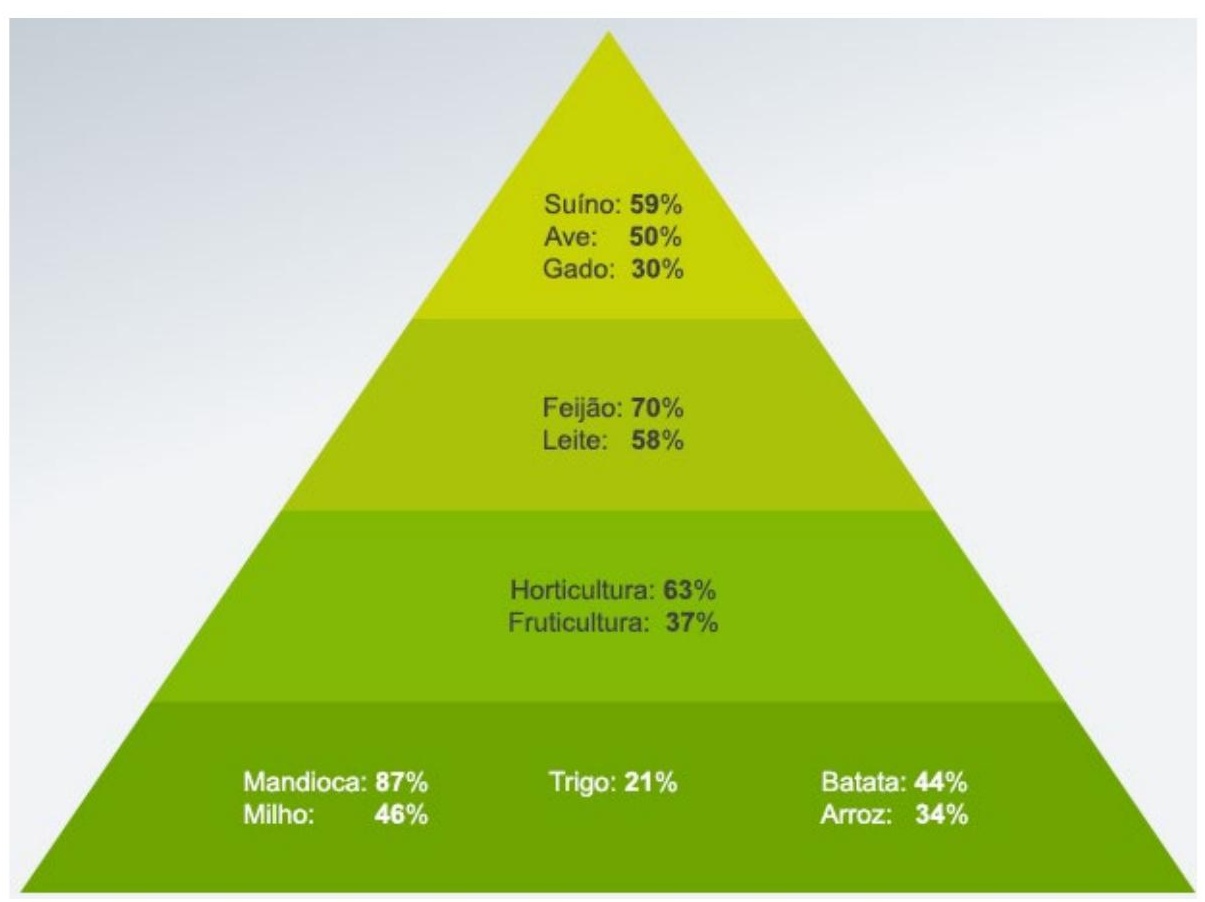

Figura 17: Produção alimentar da agricultura familiar no Brasil (Secretaria Especial de Agricultura Familiar e Desenvolvimento Agrário). 
A publicação "Isso não é apenas um livro de receitas" da fundação Heinrich Bölll sintetiza (Xavier, 2019) fala sobre a situação dos pequenos agricultores no Brasil:

"Os camponeses e camponesas do Brasil fazem muito com pouco: carregam a soberania alimentar nas costas, produzem em diversidade e qualidade alimentos que tornam a mesa brasileira essa riquíssima experiência culinária e cultural, sua economia sustenta milhares de pequenos municípios brasileiros e marcam a cultura do Brasil profundo, cuidam do meio ambiente, do solo, da água e são os maiores guardiões da biodiversidade e criadores de agrobiodiversidade" (Xavier 2019, p.140).

Os pequenos agricultores, mesmo sendo responsáveis pela maior fatia do mercado de abastecimento alimentar com diversidade e qualidade, enfrentam grandes entraves para divulgar e escoar sua produção, sendo muitas vezes dependentes de atravessadores, que acabam lucrando mais que os próprios camponeses (Xavier, 2019). Como vivem esse agricultor e sua família? O que cultiva, como e por quê? Como a sociedade urbana se distanciou da rural, de quem depende tanto, a ponto de torná-la quase invisível? A arquiteta Carolyn Steel (2007) aborda esses questionamentos trazendo à tona a consciência dos atos alimentares, a relevância de aproximar o campo da cidade, com desenho urbano, sistêmico.

Durante o evento internacional Terra Madre 2020, Steel reforçou que externalizar os custos da produção no sistema agroindustrial apenas transfere, ou posterga, a real prestação de contas que chega para toda sociedade e para o planeta, dizendo: "baratear a comida é fazer da vida algo barato." 28

Essa falsa sensação de comida acessível a baixo custo, que atende a lógica do mercado e onera todas as esferas da coletividade - do transporte à saúde, é decorrente do arquétipo do agronegócio, que vê os recursos naturais como combustível a ser utilizado para que sua engrenagem gire. Esse modelo não vê a natureza como complexo conjunto de organismos vivos interligados, que precisam ser constantemente nutridos e renovados. Partindo dessa conta, o mercado estabelece, muitas vezes, que os alimentos produzidos com métodos tradicionais, como os orgânicos ou agroecológicos, por exemplo, são mais caros. No entanto, eles apenas agregam ao seu valor de venda os custos planetários de seu cultivo/produção.

O movimento da Slow Food, que fomenta a produção e consumo do alimento bom, limpo e justo, baseia esses pilares nas características sensoriais da comida, que

28 "to cheapen food is to cheapen life." 
deve ser prazerosa, nutritiva, com mínimas interferências ambientais e respeito tanto pela natureza (ambiente e animais) quanto pela força de trabalho envolvidos da produção à distribuição e preparo destes alimentos. Carlo Petrini (2016), fundador do movimento, fala incisivamente sobre o impacto da industrialização agropecuária e desse sistema alimentar que se encontra em crise. A perda de biodiversidade e a padronização do gosto, que privilegiam as grandes redes de abastecimento são um desses. Enquanto espécies vegetais e animais são selecionadas e manipuladas em função do seu tempo de prateleira, adaptabilidade ao transporte, clima ou solo, rendimento quantitativo, o planeta segue perdendo variedade.

A diminuição da biodiversidade e cultivo de alimentos pouco influenciados pelas condições naturais (mimetizadas e uniformizadas) tem resultados diretos no sabor dos alimentos com consequências que vão além da redução na riqueza da cultura alimentar do ponto de vista organoléptico e nutricional. Além do mais, tais práticas tornam o sistema menos resiliente, mais propenso a pragas, doenças e até à extinção (Barber, 2015a).

Crises alimentares seriam muito menos drásticas se houvesse pluralidade de unidades rurais, com uma maior variedade de espécies vegetais e animais adaptadas a seus territórios e ecossistemas; se a criação e abate de animais fosse feita em pequena escala. Deste modo, quando houvesse uma infestação em uma dessas áreas produtivas, apenas uma delas seria afetada, ou seu entorno imediato, em escala local. Há que se considerar o aumento no valor unitário de alguns itens de maneira mais global, mensurando seu impacto final nos sistemas alimentares nacionais (Pollan, 2020).

A dependência de sementes geneticamente manipuladas, fertilizantes e pesticidas químicos coloca a humanidade em uma condição de fragilidade, com mais de três bilhões de pessoas atreladas à indústria agroquímica, e os desdobramentos das más práticas do agronegócio colocando outrossim o meio ambiente em situação de vulnerabilidade, impulsionando alarmantes processos de deterioração como erosão do solo, aquecimento global, poluição das águas e ar (Barber, 2015a).

Novos modelos de cultura, com métodos sustentáveis, precisam entrar em cena. Modelos que se baseiam em compartilhar o conhecimento e técnicas tradicionais, entender e respeitar o solo e os recursos biológicos, preservar e restaurar os sistemas naturais. Esses novos panoramas devem, contudo, dialogar com mercados locais, regionais e externos, desde que haja demanda e capacidade produtiva com manutenção da qualidade ética, encontrando assim condições 
equilibradas entre sustentabilidade financeira e respeito ao meio ambiente (Petrini, 2016). Carolyn Steel fecha sua fala no evento Terra Madre de 2020 com uma frase curta e marcante: "a paisagem que nos alimenta não pode desaparecer." 29

Lia Góis, da COPERAPAS (Cooperativa Agroecológica dos Produtores Rurais e de Água Limpa da Região Sul de São Paulo) e conselheira no Conselho de Segurança Alimentar de São Paulo, abordou o tema da agroecologia com um olhar atencioso durante o evento Fru.to 2020 apontando que o produto que nasce e cresce no ciclo natural é mais saudável, mais bonito, mais gostoso, ao contrário de quando a produção é induzida, onde há maior perda de nutrientes, de sabor, de apelo visual. Tratando de perdas contornáveis na produção, ela reforça que não pode se dizer agroecológico o produtor que perde, que produz mais do que é capaz de escoar. Há que se pensar no desgaste dos recursos naturais, do trabalho, tempo além dos custos financeiros evidentes da produção. Há ainda que se ter consciência de que o alimento que se perde, mesmo que vá para a compostagem, poderia alimentar algumas famílias.

Barber (2015b) complementa esse raciocínio ao afirmar que a comida que chega até as prateleiras hoje tem menos qualidade nutricional e organoléptica porque o agronegócio, justamente, não está em busca dessas qualidades. O que se quer são produtos que possam viajar bem e durem muito tempo nas prateleiras e geladeiras. O chef diz que "o papel do cardápio é juntar todas as partes novamente, e podemos fazer isso com o que a terra nos dá30"; e segue "quando você trata bem a natureza, ela te retorna com um presente a comida." ${ }^{31}$

Ballantyne-Brodie e Meroni, que frequentemente abordam o tema da alimentação, falam da importância do desenvolvimento de um sistema alimentar local para que se garanta a soberania alimentar. As inovações que o Design pode promover devem justamente e passar pelo empoderamento de indivíduos e comunidades, a despeito dos grandes interesses corporativos, e colocar as questões alimentares como meio e fim de uma vida mais saudável, para si e para o entorno. Tais inovações contemplam não apenas uma mudança na estrutura social, elas acarretando inclusive mudanças econômicas, beneficiando todas as escalas, da comunidade à urbe. (Ballantyne-Brodie et al., 2013).

\footnotetext{
29 "The landscape that feeds us can't disappear."

30 "The role of the menu is to put the pieces back together, and we can do that through what the land provides."

31 "When you treat the nature well it gives you the gift of good great food".
} 
"A superação da fome deve vir acompanhada da valorização das culturas locais e dos vínculos afetivos entre pessoas, povos e com o planeta." (Menezes \& Oliveira, 2019).

Uma análise das questões climáticas e agropecuárias mostra um cenário com grandes desafios ao comparar as décadas de 2010, 2030 e 2050, com projeções bastante dramáticas para os próximos anos, como mostram as figuras a seguir.

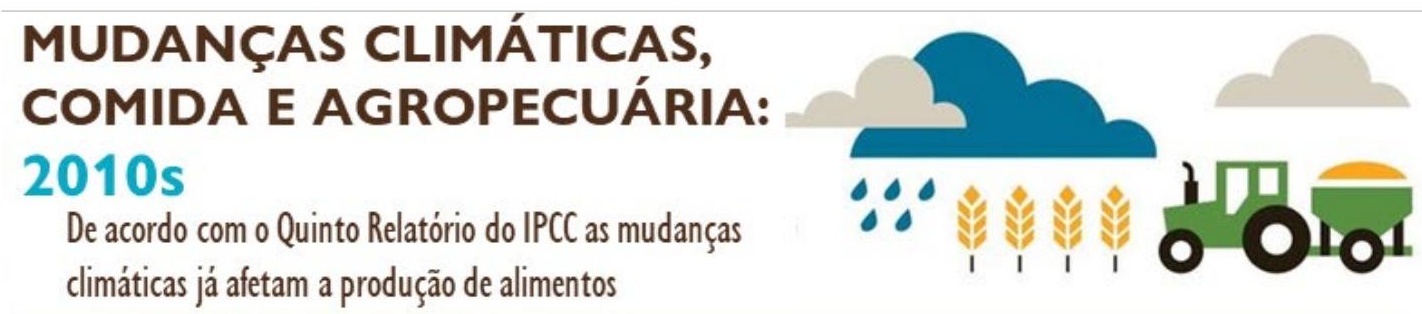

\section{COMO AFETA O RENDIMENTO DAS LAVOURAS}

Milho

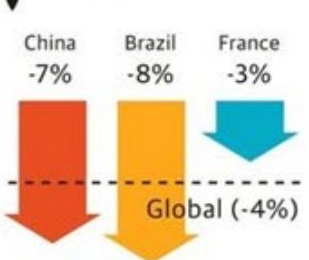

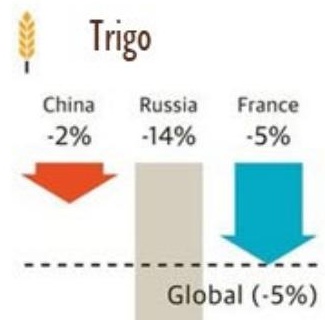

Global (-5\%)
COMO ACARRETA ALTA DE PREÇOS

Alta nos preços ligadas à eventos climáticos

extremos

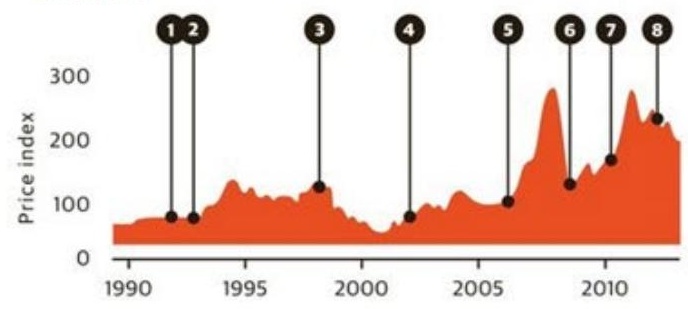

1. Australia wheat. 2. US maize. 3. Russia wheat. 4. US wheat, India soy, Australia wheat. 5. Australia wheat. 6. Argentina maize, soy. 7. Russia wheat. 8. US maize.

\section{REGIÕES TROPICAIS SÃO AS MAIS VULNERÁVEIS \\ Percentagem de desnutridos entre 2011 e 2013}
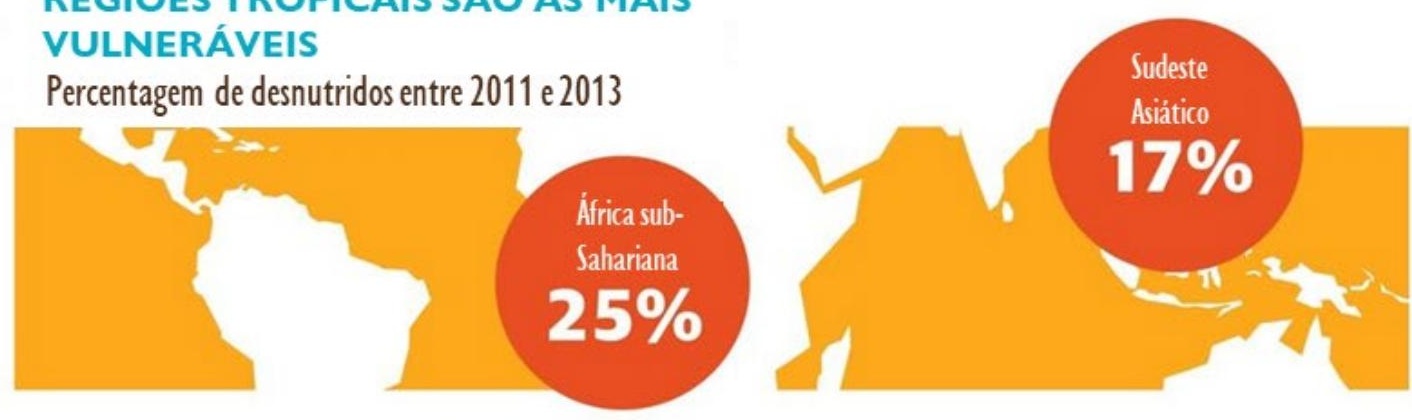

\section{PESSOAS POBRES SÃO AS MAIS VULNERÁVEIS}

População de menor poder aquisitivo gasta proporcionalmente mais do salário em comida

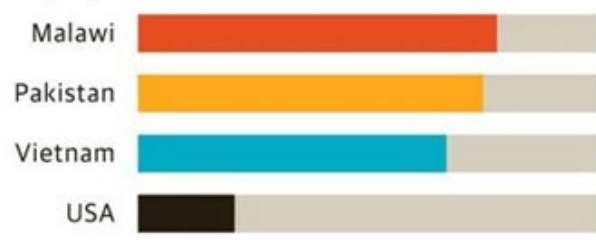

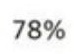

$75 \%$

$74 \%$

$21 \%$
ADAPTAÇõES AINDA NÃO SÃo SUFICIENTES

Agricultores estão

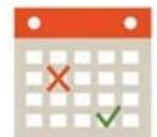

Modificando datas de plantio

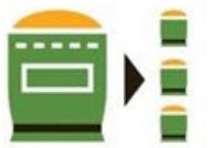

Se ajustando ao mercado diferentes espécies /variedades

Figura 18 . Perspectivas agrícolas 2010 (Climate Change, Agriculture and Food Security) 


\section{O FUTURO DA COMIDA E AGROPECUÁRIA: 2030s}

Até 2030, as mudanças climáticas terão impacto ainda maior, particularmente pequenos produtores nos paises mais pobres

\section{RENDIMENTO DAS LAVOURAS E CRIAÇÃO DE ANIMAIS DEVE DECLINAR}

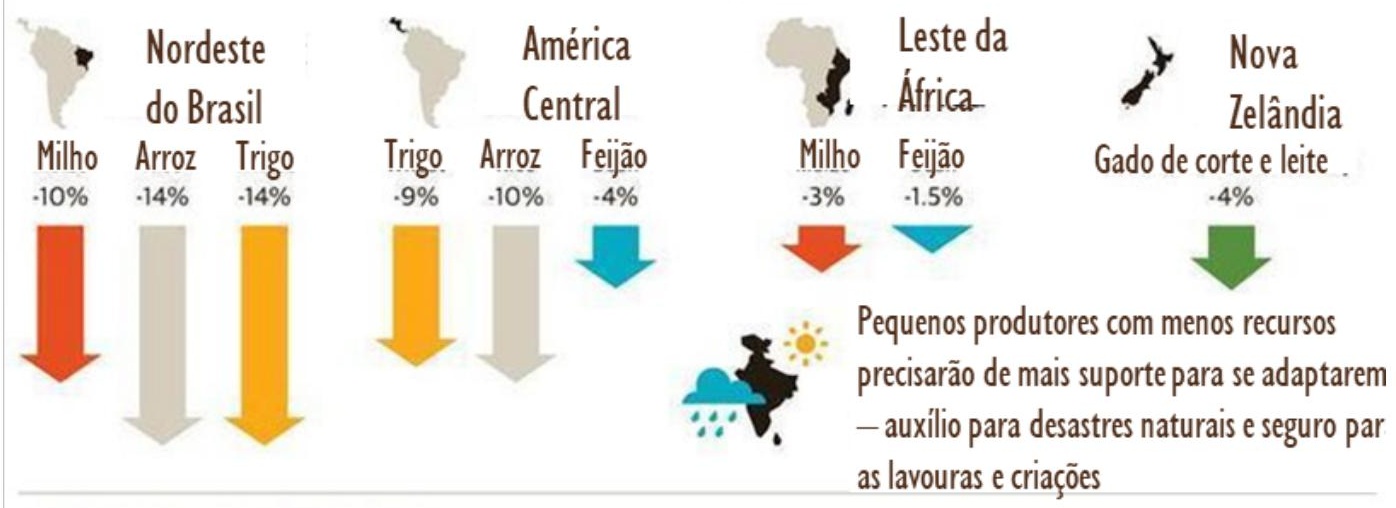

\section{ADAPTAÇÕES SERÃO CRUCIAIS}

\section{LAVOURAS}

Regiões temperadas vão ser mais beneficiadas pelas adaptações que as tropicais calor, seca ou salinidade

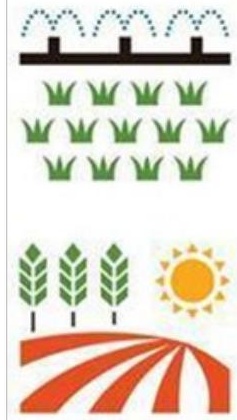

Plantar variedades mais tolerantes a0

\section{PECUÁRIA}

Adaptações fundamentais para 0 pequeno produtor:

0timizar irrigação

Gerenciar nutrição e erosão do solo

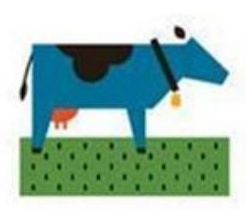

Adaptar 0

número de

animais à

quantidade de pasto

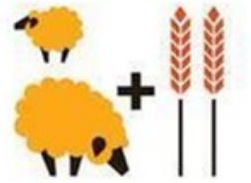

Mais fazendas com criação mista de animais e lavoura Controle de pestes, ervas daninhas e pragas

\section{PISCICULTURA}

Adaptações fundamentais para 0 pequeno produtor:

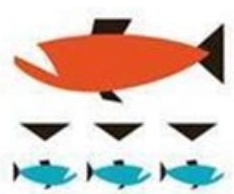

Criar espécies mais abundantes e menores

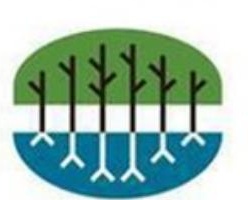

Restaurar ecossistemas degradados como mangues

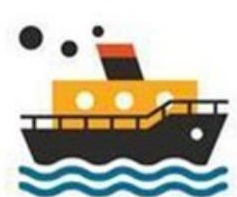

Fortalecer infra estruturas como portos e pontos de atracamento

Figura 19 . Perspectivas agrícolas 2030 (Climate Change, Agriculture and Food Security). 


\section{O FUTURO DA COMIDA E AGROPECUÁRIA: 2050s}

Até 2050, os impactos climáticos na segurança alimentar serão inegáveis.

Estima-se uma população de 9 bilhões de pessoas, a maioria vivendo em centros urbanos, com grande aumento na demanda por comida

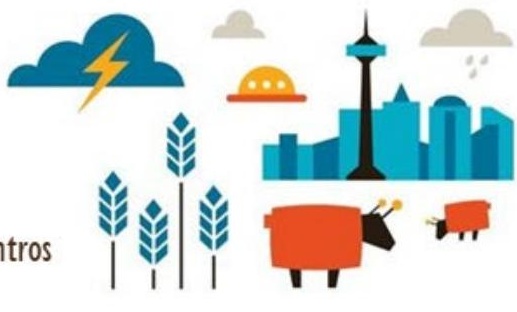

\section{IMPACTOS NA COMIDA E AGROPECUÁRIA SÃO INEVITÁVEIS}

Declínio médio de $8 \%$ nas 8 principais lavouras da África e Sudeste Asiático
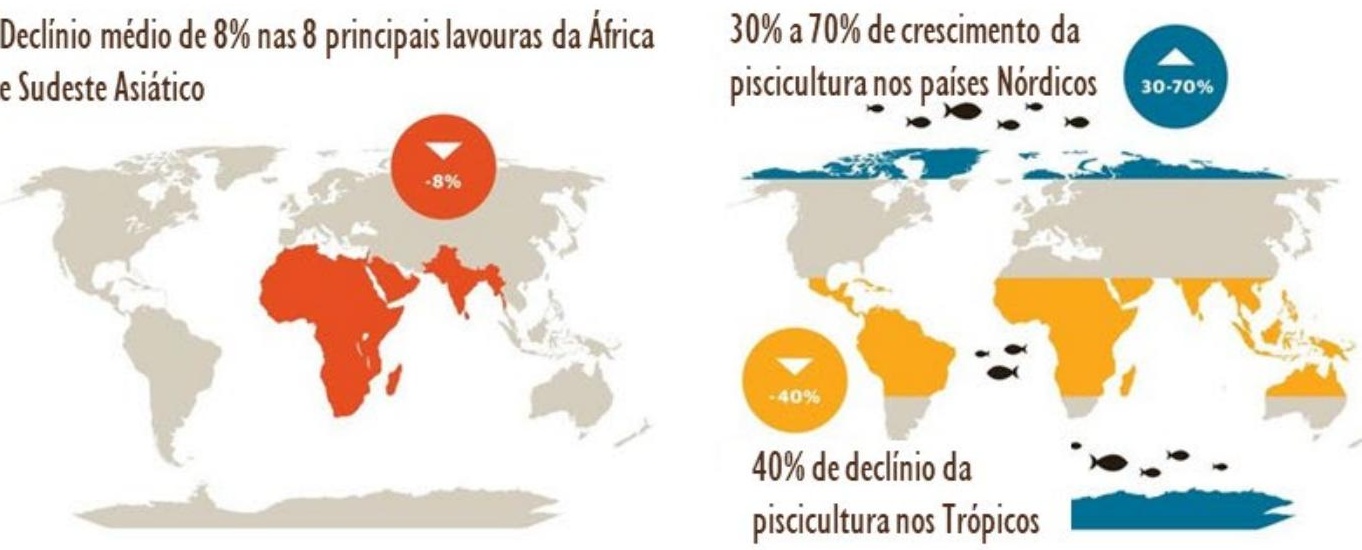

\section{CALOR E ÁGUA DEVEM ULTRAPASSAR LIMITES}

Aumento de mais

de 4 C de

temperatura

coloca em risco a

capacidade de

adaptação dos

ecossistemas

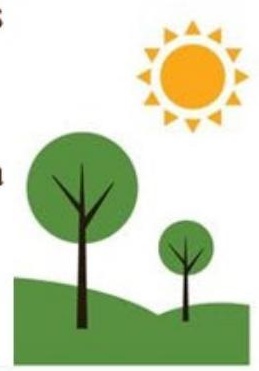

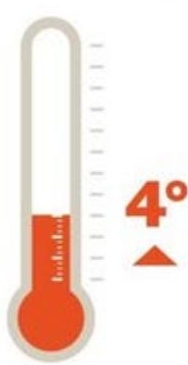

Os ciclos aquáticos serão diferentes e imprevisiveis

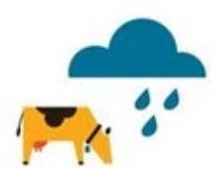

Mudanças na intensidade, frequência e sazonalidade das chuvas

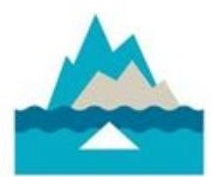

Aumento do nivel do

mar com 0

derretimento dos glaciares

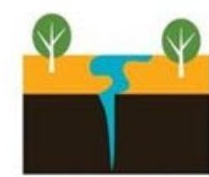

Mudanças nos lençóis freáticos e curso dos rios

INOVAÇÕES URGENTES NA MANEIRA QUE PRODUZIMOS E CONSUMIMOS Para lidar com as mudanças climáticas, precisamos considerar:

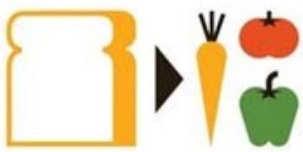

Mudanças radicais da dieta

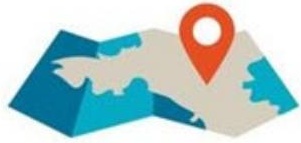

Trocar a produção em larga escala por local

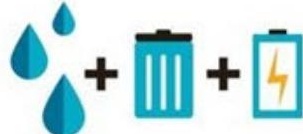

Novas abordagens para residuos, água, energia e cadeias de consumo

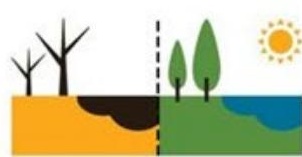

Restaurar áreas degradadas, mangues e florestas

SOURCES: Porter, J. R., Xie, L., Challinor, A., Cochrane, K., Howden, M., Iqbal, M. M., Lobell, D., Travasso, M. I. 2014. Food Security and Food Production Systems. In: Climate Change 2014: Impacts, Adaptation, and Vulnerability. Contribution of Working Group II to the Fifth Assessment Report of the Intergovernmental Panel on Climate Change. http://www.ipcc.wg2.gov/ With data from Cheung et al 2010. Cochrane et al 2009. Knox et al 2012

Figura 20 . Perspectivas agrícolas 2050 (Climate Change, Agriculture and Food Security). 


\subsection{Chef de cozinha}

"Eu acredito fortemente que cozinhar é uma atividade física. Ela requer um condicionamento. Por ser dura, extenuante e com alta demanda de tempo, a cozinha atrai pessoas que têm uma tendência ao abuso. É estimulante, e o desafio é algo como: "Quanto disso você aguenta?" Isso é uma maneira de viver uma vida feliz? Eu não sei responder, de modo algum. Eu me pergunto" 32 (Barber, 2015b).

Em algum ponto situado entre as extremidades da cadeia produtiva, encontramos os cozinheiros e chefs, circundados da sua brigada de cozinha, geralmente em um restaurante. Esses profissionais, com educação formal ou empírica, têm como atividade e renda principais o preparo de refeições para venda ou distribuição, em diferentes ambientes e escalas produtivas. O chef de cozinha é um cargo, ocupado pelo cozinheiro, que envolve gestão tanto da brigada quanto do que é produzido na cozinha, e sua função, análoga à de um maestro, é de reger cozinheiros, equipamentos e alimentos para uma composição final que nutra e cative o consumidor, com sustentabilidade financeira.

Como bem descrito por Barber (2015b), cozinheiro é uma profissão de grande dedicação, alta carga horária e demanda física, com periculosidade e pressão constantes. A realidade do mercado mundial é marcada por salários comparativamente baixos, estruturas altamente hierarquizadas e dominada por homens.

O cozinheiro chef, afora responsável pela gestão da equipe da cozinha e relacionamento com a equipe de serviço; elabora cardápios, realiza cálculo de custos, fichas técnicas, escolhe e compra os ingredientes. Concerne a esse profissional combinar insumos e técnicas para trazer o melhor da cultura gastronômica, com o menor custo, até a mesa do cliente. Além de ser a interface da equipe da cozinha para praticamente todas as interações, ou por isso mesmo, está sempre sujeito às exigências dos sócios/proprietários e demandas do mercado, onde deve se sobressair.

32 "I believe strongly that good cooking is physical. It demands a kind of conditioning. Because of the drudgery and the hours, and the exhaustion that this kind of work demands, it does attract people who are attracted to a certain kind of abuse. It's exhilarating, and the challenge is sort of "How much of it can you stand"? Is that the way to live a happy life? I don't have the answer to that... at all. I wonder". 
Cabe ao chef e sua equipe selecionar, receber e aplicar técnicas para transformar os alimentos, apresentando verdadeiras experiências visuais e de paladar ao consumidor final. Além de ter poder de escolha e compra dos insumos (particularmente se tiver participação societária), o chef de cozinha pode ser um importante disseminador dos produtos de origem rastreável e reputável. Baseado nos preceitos de qualidade, sazonalidade, diversidade e preço, há muito que se trabalhar sobre a compra da matéria prima. É uma prerrogativa do chef de cozinha estabelecer que padrões irá seguir e atingir com sua comida.

Elaine Azevedo, nutricionista e socióloga da alimentação acrescenta uma camada ao conceito da profissão:

"Cozinheiras e cozinheiros são humanos que trilham suas vidas junto à dos alimentos e dedicam-se a eles diariamente. Essa caminhada conjunta faz parte de uma jornada de vidas construída historicamente, composta por muitos momentos de experiência culinária, bem como por diversos aspectos simbólicos e culturais que antecedem a vivência dentro da cozinha. Nesse sentido, voltar a atenção para questões socioculturais e simbólicas que englobam a alimentação é essencial para compreender como a relação entre cozinheiros e culinária é formada. Cozinheiros não nasceram com uma conexão inata com os alimentos, eles criaram um poderoso afeto pela comida ao longo de suas vidas. Sendo assim, como é estabelecida esta íntima relação entre humanos que cozinham e a culinária? Quais aspectos socioculturais e simbólicos ajudam a construir essa rede de afetos?" (Altoé \& Azevedo, 2020).

A conexão com a natureza, é muitas vezes ignorada na rotina profissional da cozinha. Habituados à mercantilização dos insumos, chefs de cozinha e sua equipe tratam os insumos como matéria prima bruta, com pouca ou nenhuma reflexão sobre como e por que mãos, esse alimento, na verdade, passou.

Se, como afirmou Poulain (2006, p.161), "o homem é um animal cozinheiro", pode-se dizer que não há sociedade humana sem tradições e rituais alimentares, e que tanto sua construção quanto sua evolução se baseiam, fundamentalmente, nos processos de cozimento e preservação dos alimentos, nos diferenciando, de maneira singular, do restante dos animais. Cerca de 2,5 milhões de anos separam o homo habilis do homo sapiens, e suas mudanças de hábitos, aprendizado e domínio de técnicas de cultivo, do fogo e de cocção são marcos de evolução social, que permitiram o caçador/coletor nômade a possibilidade de se fixar à terra, plantar, processar alimentos e ter o que consumir em períodos de estiagem (Poulain, 2006),

Em um salto para a contemporaneidade, Lívia Barbosa retoma preceitos da sociologia clássica da evolução do gosto, das práticas alimentares, e aborda indagações éticas e estéticas da alimentação. Como tratado no Capítulo 2.2 Comida, há muitos fatores que influenciam as decisões sobre o que comer, e vão desde indagaçõ̃es pautadas pela ciência e saúde física, como orientação médica ou nutricional, passando pela tomada de consciência do impacto ambiental, até 
questões socioculturais como rituais, tradições, sabores e apelo visual (Barbosa, 2009).

Com a terceira revolução alimentar pautada no hábito de comer fora do ambiente familiar, Warde \& Martens (1998) acessam a mudança das práticas alimentares, com a transferência da responsabilidade das escolhas domésticas para o profissional da cozinha, capaz de consolidar ou modificar padrões de alimentação. Outro sociólogo que traz esse olhar sobre a profissão do cozinheiro é Featherstone (1991), colocando os chefs de cozinha como protagonistas na mediação do aprendizado do gosto, na educação do paladar.

Os chefs de cozinha podem ser, nesse contexto, embaixadores de diferentes práticas e proposições alimentares. Como um consumidor especialista, em um paralelo ao designer especialista proposto por Manzini (2015), o chef de cozinha tem potencial para ser um educador do gosto, com claros posicionamentos ético e estético, de influenciador e formador de opinião. Quando esse chef compreende que seu legado pode ir além de prêmios por apuro técnico e formal, quando ele se coloca como parte da cadeia dos alimentos, ele demonstra que o respeito por todos os atores reflete na perpetuação da saúde, na manutenção do planeta (Araium, 2020).

Afora todos os aspectos técnicos, há um crescente reconhecimento da importância da profissão pela sociedade. Uma evidência palpável disso é a profusão de cursos profissionalizantes e universitários de Gastronomia à partir da década de 1990. Em um rápido panorama, a primeira escola de formação profissional de cozinha, inaugurada em 1895 em Paris, foi a escola Le Cordon Bleu, passando pelo CIA (Culinary Institute of America) em Nova lorque (1946), ao primeiro curso técnico brasileiro de cozinha, veiculado de Senac (Serviço Nacional de Aprendizagem) Águas de São Pedro em 1969. Ainda assim, todos esses cursos eram de caráter profissionalizante, voltados para a qualificação de mão de obra para pronta entrada no mercado de trabalho, com mínima percentagem da efetiva força de trabalho nas cozinhas profissionais tendo passado por qualquer tipo de formação. Em 1994, em uma parceria Senac e CIA, foi lançado o curso de Cozinheiro Chef Internacional, e em 1999 finalmente vieram os primeiros cursos superiores de Gastronomia no país: Bacharelado em Turismo com Habilitação em Gastronomia na Universidade do Sul de Santa Catarina e o Curso Superior de Formação Específica em Gastronomia na Universidade Anhembi Morumbi em São Paulo (Rocha, 2016).

Outro proeminente vestígio da popularização da profissão é a quantidade e variedade de mídias protagonizadas por chefs, com filmes e séries dedicadas ao 
tema. Essa exposição do chef atrai consigo os holofotes da mídia no tocante à sua capacidade de influência sobre o comportamento e os hábitos de consumo das pessoas. Esse poder da mídia aumenta a responsabilidade, pois esse cozinheiro, no papel de consumidor especialista, pode influenciar e deslocar as demandas por uma agricultura mais sustentável através do impacto sobre os consumidores finais. Ao modificar a forma como a comida é percebida e consumida, haverá juntamente uma transformação nas relações sociais e econômicas estabelecidas entre o usuário final e o produtor.

Para o chef Dan Barber (2015b), o papel do chef na mudança do comportamento é central, e se dá através do poder midiático inédito desse profissional. Ainda que haja controvérsias, o status de celebridade alcançado por alguns expoentes das cozinhas mundiais abre espaço para discutir, propor e influenciar o comportamento dos consumidores.

Pollan (2006) aponta a importância de se comer o que é local, da estação, e o quanto a indústria da alimentação fomentou a comodidade de se comer o que quiser, quando quiser. É hora de repensar esse modelo que explora os recursos naturais, e muito dessa reconstrução está nas mãos dos chefs. Barber conclui de maneira clara a responsabilidade contemporânea do chef: "passados pouco mais de cinquenta anos da Nouvelle Cuisine, os chefs de cozinha são reconhecidos por sua habilidade de criar modismos e direcionar o mercado" 33 (Barber, 2015a, p.10).

Sendo uma ponte do produtor para o consumidor, o chef de cozinha dissemina seu conhecimento sobre a origem e características qualitativas dos insumos, e consolida ou modifica uma cultura alimentar. Para além da crescente visibilidade do profissional, houve grandes mudanças quanto à forma como o alimento é tratado e oferecido, e até certo ponto, o mesmo aconteceu com o fornecimento das matérias primas. A opção dos insumos é uma decisão que contempla aspectos quantitativos, qualitativos e de logística. Ao longo da cadeia de consumo alimentar, o chef de cozinha é esse intermediário cultural, um profissional que detém o conhecimento para melhor escolher os ingredientes, sendo também é responsável por pensar na origem dos produtos, quais rótulos o restaurante vai reforçar e transmitir essa imagem adquirida através da comida servida.

33 "Fifty years later, chefs are known for their ability to create fashions and shape markets." 
A escolha consciente determina como será a operação da cozinha, a oferta do cardápio, e o tipo de relação que será estabelecida entre as partes envolvidas na cadeia. Quanto menores as distâncias percorridas pelos alimentos, menores as perdas - que chegam a $28 \%$ no consumidor, pós distribuição (FAO, 2020), maior a qualidade, o frescor.

Francine Xavier, chef de cozinha e pesquisadora consolida a responsabilidade dos chefs, quando afirma que

\begin{abstract}
"Um produto esquecido, em suas mãos, vira um hit! O chef contemporâneo sabe que sua responsabilidade transborda o gosto e vai além do prato. Seu posicionamento tanto influencia as escolhas dos consumidores, quanto o expõe ao julgamento dos mesmos. Junto com poderes chegam responsabilidades $e$, felizmente, os questionamentos. O que o alimento que eu uso alimenta? A quem meu trabalho serve? Posso ajudar a construir o mundo que desejo? Da reflexão, nasce a constatação de que a maneira como produzimos, distribuímos e comercializamos alimentos" (Xavier, 2019).
\end{abstract}

Sendo um consumidor especialista, o cozinheiro chef tem as habilidades técnicas para trabalhar os ingredientes, até mesmo os desconhecidos, desenvolvendo maneiras de prepará-los e apresentá-los. O chef é, de certa forma, uma conexão entre o campo e a cidade e, em uma situação ideal, liga os dois mundos, fundindo as extremidades da cadeia. O movimento Slow Food tem um grupo mundial chamado Chef's Alliance, empenhado em perpetuar as tradições alimentares, a biodiversidade, a cultura local e os produtores de alimentos artesanais. A filosofia do movimento é de que os chefs têm um papel fundamental na proteção da diversidade biológica e cultural de nossos alimentos. Eles interpretam as histórias e os ecossistemas de suas regiões com habilidade e criatividade, apoiando os produtores locais enquanto despertam os consumidores para o papel compartilhado de guardiões da biodiversidade.

Os preceitos do Slow Food são compartilhados por inúmeros chefs e consumidores mundo afora, e a resposta ao movimento americano do Fast Food não poderia ter sido mais adequada. A reboque desse movimento, alguns profissionais passaram a questionar o modo como seus cardápios eram elaborados, suas operações de cozinha conduzidas.

"A história da alimentação mostrou que cada vez que identidades locais são postas em perigo, a cozinha e as maneiras à mesa são locais privilegiados de resistência" (Poulain, 2006, p.38), e os movimentos de valorização do regional através dos alimentos protagonizaram conquistas com selos de DOC (Denominação de Origem Controlada), gastronomia étnica, e da Nouvelle Cuisine francesa da década de 1960 emplacando o discurso da valorização do local, da sazonalidade, de uma cozinha mais leve. Não obstante, o chef fundador dessa corrente, Paul Bocuse, 
propunha com a nova cozinha francesa que os chefs se libertassem das receitas clássicas, dos molhos pesados à base de proteína animal, manteiga e creme, estimulando sua criatividade justamente com o rompimento das tradições, evidenciando o sabor e características naturais dos insumos. $\mathrm{Na}$ contemporaneidade, Dan Barber foi um dos primeiros a serem colocados na categoria de "farm to table", ou campo-à-mesa, que dispara novamente o gatilho da valorização da produção agrícola em pequena escala e próximo do consumidor. Em seu livro "Terceiro Prato" (2015), Barber descreve como o "campo-à-mesa foi de uma ideia periférica a um movimento social dominante" ${ }^{44}$ (Barber, 2015a, p.09). O livro aborda uma temática de sustentabilidade que vai além de levantar as questões sobre os agricultores e a sustentabilidade no campo. Ele traz à luz o fato de que tudo que se come é parte de um todo, uma rede de relacionamentos, que não pode ser reduzida à simples escolha de ingredientes.

Com uma propriedade rural no entorno de Nova lorque, onde produz grande parte dos ingredientes servidos em seus dois restaurantes, Dan não tem dúvidas que o sabor do ingrediente é consequência da qualidade do seu entorno, e foi na obsessão pelo melhor sabor que ele descobriu que havia todo um sistema por trás. O trabalho da fazenda e restaurantes é focado na melhoria contínua do sistema. Extensos projetos de pesquisa com profissionais de todas as áreas, vinculados a universidades e empresas, são desenvolvidos na Granja Blue Hill, com intuito de mudar a comunidade e o mundo. Segundo Barber, a boa comida

"dialoga com algo que vai além da colheita, do cozinheiro, do agricultor - para a totalidade da paisagem, e como ela se encaixa. Ela se expressa em sua melhor forma em lugares onde boa agricultura e comida deliciosa são inseparáveis" 35 (Barber, 2015a, p.08).

Há um crescente número de chefs de cozinha que entendem que precisam fazer mais que comida bonita e gostosa, que suas responsabilidades com a sociedade vão além do paladar. A nutricionista e chef de cozinha Lis Cereja se destaca no cenário nacional de restaurantes sustentáveis, com um modelo de restaurante-fazenda. Ela afirma que

"é papel do chef de cozinha incentivar as boas escolhas alimentares, a compra da agricultura familiar, a opção pelo consumo local, a dedicação à cozinha e à saúde, e a

\footnotetext{
34 "Farm-to-table has since gone from a fringe idea to a mainstream social movement."

35 "it (good food) speaks to something beyond the crop, the cook, or the farmer - to the entirety of the landscape, and how it fits together. It can best be expressed in places where good farming and delicious food are inseparable"
} 
busca de informações sobre ingredientes e tradições alimentares. "É ensinar como fazer, dar o exemplo e ajudarmos uns aos outros. Tudo isso visando uma mudança global de estilo de vida para melhor, para um mundo mais consciente e mais saudável em todos os aspectos" (CEREJA, 2020).

Outra profissional que abraçou o "locavorismo" é a chef Manu Buffara, cujo restaurante é abastecido parcialmente por vegetais de uma Horta Urbana comunitária, que supre, além de seu estabelecimento, seus funcionários e as famílias atendidas pelo projeto. A horta existia desde 1986, mas tomou novo fôlego e propósito depois de 2013 quando a chef embarcou no projeto. Seu trabalho com os agricultores é de estudar o clima, programar antecipadamente que alimentos estarão disponíveis em determinados períodos, para então pensar os pratos e receitas que serão criados. Para a chef, o relacionamento com o produtor deve transcender a materialização dos desejos do chef, a natureza não é um serviço de entrega. Há um tempo para semear, crescer e colher que precisa ser respeitado, "você não pode ir com uma receita, você tem que esperar o que o produto pode te trazer" (Buffara, 2018a).

Manu vê a gastronomia pela ótica da economia circular, com valorização dos alimentos e produtores, em um modelo sustentável. Seu menu é baseado nos insumos de cerca de 35 pequenos produtores regionais, com quem há muita troca. Eles trazem produtos desconhecidos, ela aborda temas como a preservação do solo, meio ambiente e estratégias de negócio.

"A gente precisa entender que não cozinhamos só para encher a barriga. Há todo um movimento que não se trata só de comprar o alimento, mas de ensinar o produtor e desenvolver junto a forma mais inteligente de fazer. Sempre fui adepta a isso: produto com menos viagem, com menos poluição e gerando renda local, um trabalho mais orgânico" (Buffara, 2019).

A chef destaca a visibilidade que advém dos prêmios e do reconhecimento internacional que conquistou ao longo da carreira, e se preocupa em deixar um legado de conteúdo, que culmine na transformação dos hábitos de consumo, no contato com a origem do alimento, na maior frequência às feiras. A chef enfatiza "Quando a gente ganha essa voz como chef, é muito legal poder passar também informação. E isso tem ajudado a mudar as pessoas" (Buffara, 2018a).

"Cozinhar para mim é uma expressão de amor, conhecimento, técnica, autenticidade e respeito. Respeito ao produto, ao produtor, ao cozinheiro, ao meu avental e à minha família [...] Acredito que podemos mudar a alimentação de uma nação com pequenas ações que iniciam na terra e dentro de nossas casas" (Buffara, 2018b).

Petrini (2014) sustenta que a mudança nos paradigmas da alimentação esteja nas mãos dos chefs de cozinha, e que, enquanto esses profissionais não 
compreenderem que a natureza não pode estar a seu serviço, e sim o contrário, não haverá possibilidade de a agricultura familiar emergir.

Essa ideia reforça o que foi dito por Pollan (2006) quase uma década antes: "a maneira como comemos e compramos é indissociavelmente ligada ao tipo de agricultura e sistema alimentar que temos, e não iremos conseguir mudar um sem mudar o outro." 36

As perguntas que circundam os chefs que decidiram adotar princípios mais sustentáveis para seus negócios são quase sempre as mesmas. Vale apostar na sustentabilidade? Quanta energia e trabalho são necessários, a mais ou a menos, para se adequar? Qual o custo imediato? Como lidar com as questões diárias trazidas por essa opção? O cardápio que muda constantemente, a expectativa do cliente, o retorno financeiro. A literatura sobre restaurantes sustentáveis é ainda escassa, como bem fundamenta o chef de cozinha e pesquisador Matheus Zanella (2020) em seu artigo. Matheus elenca em seu estudo dez princípios para a sustentabilidade alimentar, que abarcam serviços e relações entre os produtores, cozinheiros e consumidores da cadeia de consumo:

- "Abrace a diversidade e a sazonalidade como base para a sustentabilidade alimentar;

- Cozinhe comida de verdade: mínimo processamento e priorização de produtos saudáveis, frescos e nutritivos;

- Priorize o local, mas não feche fronteiras;

- Prefira alimentos orgânicos e/ou agroecológicos; rótulos são importantes, mas o que realmente importa é como os alimentos são produzidos;

- Adote uma dieta baseada em vegetais, mas tenha em mente que muitos sistemas alimentares requerem animais para alcançar a sustentabilidade;

- Favoreça os pequenos produtores: seus esforços pessoais compensam em qualidade, enquanto a renda permanece na economia local e os benefícios serão compartilhados de forma mais justa em todo o sistema alimentar;

- Reduza o desperdício ao mínimo: reduza, reutilize, recicle. Seja eficiente e adote uma abordagem de cozinha "do focinho ao rabo";

- Seja inovador, mas nem sempre reinvente a roda; em muitas situações, ser inovador significa voltar às nossas raízes e tradições;

36 "The way we shop and eat is inextricably linked to the kind of agriculture and food system we have, and we won't change the one before we change the other." 
- Considere que a indústria de alimentos precisa ser consertada, mas nós estamos viciados ao sistema. Soluções radicais inspiram, mas nem sempre nos levam a uma mudança gradual necessária; e

- Mude receitas, técnicas, ingredientes: nunca sacrifique o sabor." ${ }^{37}$

A partir desses fundamentos fica mais fácil visualizar que, para ser baseado em agricultura familiar e local, o estabelecimento precisa estabelecer algumas regras internas e externas. O processo de elaboração, levantamento de custos e oferta do cardápio, por exemplo, tem que ser construído seguindo mais a lógica da natureza e menos a do mercado. A elaboração dos pratos inicia com os insumos disponíveis. Haverá potencialmente um exercício semanal de criação a partir do que o produtor oferece, então a organização e planejamento são primordiais. Além disso, a questão da precificação deve ser contemplada. Pode parecer lógico que os produtos sazonais sejam mais abundantes e com melhor custo, mas nem sempre esse raciocínio é percebido com clareza, e se o chef não souber aproveitar o que a natureza oferece, quando oferece, coloca a perder esse raciocínio. Finalmente há o consumidor final, que pode não estar preparado para as mudanças tão constantes, e desejar encontrar o conforto da comida a que está familiarizado. Como tal proposta é apresentada para o cliente, explicitando seus vastos benefícios, é igualmente tarefa para o chef.

A chef Alice Waters (2020), provável pioneira do farm-to-table, explorou recentemente o quanto a pandemia do COVID-19 deixou expostas as cadeias de produção e consumo de alimentos, colocando ainda mais pressão na temática das práticas tóxicas e insustentáveis do sistema agrário contemporâneo. Fica cada vez mais evidente, segundo a chef, que "menor é melhor" quando se trata de cadeias

37 "Embrace diversity and seasonality as the basis for food sustainability; Cook real food: minimal processing, and prioritising wholesome, fresh and nutritious products; Prioritise local, but do not close borders; Prefer organic and/or agro-ecological food; labels are important, but what really matters is how food is produced; Adopt a vegetable-oriented diet, but keep in mind that many food systems require animals for achieving sustainability; Favour small producers: their personal efforts pay off in quality, while income stays in the local economy and the benefits will be more fairly shared across the food system; Reduce waste to a minimum: reduce, reuse, recycle. Be efficient and adopt a nose-to-tail approach to cooking; Be innovative, but do not always reinvent the wheel; in many situations, being innovative means returning to our roots and traditions; Consider that the food industry needs fixing, but we are addicted to it. Radical solutions inspire but do not always lead us to a needed gradual transformative change; and Change recipes, techniques, ingredients: never sacrifice taste." 
alimentares, e os benefícios das redes locais, de pequena escala, com sistemas regenerativos, são muito mais resilientes que as redes de larga escala.

Os sistemas menores têm potencial capacidade para inovar no cenário de (in)segurança alimentar, direitos trabalhistas, agrários e das mudanças climáticas. Waters fala ainda sobre a urgência em tratar do tema da alimentação sustentável, do quanto a sobrevivência da geração atual e das próximas está diretamente vinculado a isso, e da responsabilidade que cabe, nessa discussão, aos chefs e restaurantes, quando afirma que "o futuro do planeta depende do sucesso dos sistemas alimentares, e está em nossas mãos garantir que esse sucesso aconteça" (Foodsystems, 2020).

Os anais do EFood Lisboa 2019 trazem essa temática para as mãos dos chefs de cozinha em algumas oportunidades, reafirmando a capacidade e poder de influência dos chefs e restaurantes em modelar os desejos em torno da gastronomia, para que um futuro mais sustentável seja viável. Suzana Parreira enfatiza que, ao endossar um produto, o chef de cozinha exerce uma influência sem precedentes, em que "um prato não é mais algo apenas para ser consumido, mas simultaneamente uma forma de expressão individual, uma forma de comunicação" 38 (Bonacho et al., 2020). Ainda segundo Parreira, essa influência perpassa a esfera da cozinha profissional e chega até a escala doméstica, em um movimento apontado igualmente por Deakin (2019) como necessário para uma alimentação mais consciente, que é encorajar nas pessoas o hábito de cozinhar em casa.

Esse pensamento é amparado na reflexão de Goodman (2003) sobre as práticas culinárias tradicionais "e sua relação com a produção artesanal, com a ecologia e economia local, que podem ser considerados como resposta à globalização, à mudança tecnológica e à rápida concentração industrial."

Dentre tantas atribuições, a tomada de consciência e preocupação com os dilemas do complexo sistema alimentar evidencia o papel de destaque ocupado por um grupo seleto de chefs de cozinha, que buscam ampliar as fronteiras do fazer culinário com técnicas, tecnologia ou soluções inovadoras. Como debatido por Zampollo (2016) e Zampollo e Vogelzang (2015) estas são características que colocam esses chefs no papel de Food Designers.

\footnotetext{
38 "a dish is no longer just something to be consumed but simultaneously an expression of self, a form of communication."
} 
Trabalhando em associação com designers especialistas, eles podem, em conjunto, compreender as dimensões do cenário existente e propor novos significados e valores para um sistema alimentar mais equilibrado. Para Barber, o prato de comida conecta, concatena ideias de todos os profissionais relacionados ao tema da alimentação, passando por nutricionistas, ecologistas, economistas entre tantos outros. Esse é justamente o poder do chef, colocar todas as questões sobre a mesa (Barber, 2015b).

\subsection{Consumidor}

"Você é aquilo que você come. E o que alimenta o que você come" 39 (Michael Pollan, 2006).

O último dos três atores da cadeia, mas sem dúvida não menos importante, é o consumidor, indivíduo com variado poder econômico e de decisão para adquirir produtos e serviços. Peça fundamental na engrenagem dos sistemas alimentares, é pelo consumo que os indivíduos acessam o que foi produzido, e através dele influenciam o que será produzido subsequentemente. A cultura alimentar, formada pelas normas sociais, crenças, valores, é determinante nas escolhas e padrões de consumo, podendo ser uma característica identitária de um grupo ou sociedade (Foodsystems, 2020).

Se, a partir da década de 1960, Marcel Mauss trouxe o ato de comer como um fato social total, ou seja, que interfere em todas as esferas da vida, as décadas de 1970 e 1980 viram um fervilhar de contradições no cerne do sistema alimentar industrial, com os primeiros sinais de preocupações sobre segurança alimentar, saúde, e o surgimento das primeiras redes alternativas de alimentos. Os estudos sociológicos sobre esses fenômenos culminaram com, no final da década de 1990, uma retomada no entendimento das relações de produção e consumo na chamada "cultural turn", ou virada para a cultura, em que seus impactos políticos, sociais e econômicos deixam de ser vistos pela ótica das relações de produção ou de classe, e passam a ser enxergadas como fenômeno cultural. A reboque dessa análise, alguns estudiosos focaram no ativismo alimentar, na construção política dos modelos alternativos de provisionamento do alimento, e nas relações iterativas que conecta,

39 "You are what you eat. And what you eat eats". 
nesse contexto, produtores e consumidores (Barbosa, 2009; Wilkinson 2009, 2010, Portilho 2010).

Goodman, DuPuis e Goodman (2012) reforçam essa abordagem da sociologia que coloca a comida e consumo como um reflexo das relações e significados sociais, colocando os consumidores como um grupo poderoso no ditame de parâmetros como direitos, obrigações e regras de conduta para os processos.

A sociologia tem se debruçado sobre esse tema (com recorte especial para alimentação), que entende ser o fenômeno central da sociedade contemporânea, colocando o consumo como base da identidade cultural. Isso permite contemplar os fatores culturais e as preocupações éticas como causadores de mudança no comportamento do consumidor, que entende as consequências de suas escolhas com responsabilidade, e percebe que os impactos socioambientais podem ser potencializados ou minimizados por sua decisão de compra. (Zanetti, 2017; Cassol \& Schneider, 2019; Barbosa 2009).

As referidas bases sociológicas defendem que as escolhas de consumo são pautadas por diferentes graus de poder aquisitivo, cultura, conhecimento, confiança e necessidade dos produtos; e que tais fatores são fortemente influenciados por modismos, nutricionismo, mídia digital, pseudociência, relação afetiva com algumas marcas ou tipos de comida; todos frutos de um aparato sociocultural. Nessa mescla de coeficientes, têm destaque a padronização do gosto, imputada pela indústria da alimentação, com a construção paulatina de um gosto universal, com estrangeirismos de paladar e práticas que foram absorvidos sem grandes questionamentos. Uma implicação direta dessa política de exportação de modelos de culinária local que, paradoxalmente, não levam em conta o local, é a dissociação da cultura culinária e do modo de vida, que precisam estar atrelados. Perdem-se tradições, histórias, cultura, ao se afastar, cada vez mais das origens, do campo, da biodiversidade regional (Zanetti, 2017).

Essa breve análise sociológica mostra que o consumidor está acordando para seu papel político, exercendo seu direito de saber mais sobre a comida que compra, e traçando novos parâmetros para uma verdadeira aliança consumidor-produtor, pautada em eco sociabilidade. Mesmo ainda sendo visto como um movimento de classe média, escolarizada, privilegiada - "uma dieta de classe" - não deslegitima sua força de política alimentar e de inovação social. As redes alternativas propõem novos processos que visam integrar a complexa relação produtor-consumidor, englobando as questões morais, econômicas, éticas, e colocando-as nas práticas cotidianas. 
Em uma conjuntura social em que se estima que $68 \%$ da população esteja vivendo em áreas urbanas até 2050, acende o alerta para o fato de que a urbanização alonga as cadeias de produção e consumo de alimentos - maior distância do campo, mais processamento, empacotamento, perdas, transporte - e promove, através de seu modo de vida, o hábito de realizar uma maior quantidade de refeições fora do domicílio, em formatos menos tradicionais. O que se projeta são situações de desequilíbrio no abastecimento, previsão de abundância de alimentos processados e ultra processados a preços mais acessíveis, enquanto a comida fresca e saudável é colocada, cada vez mais, em um nicho socioeconômico inalcançável para grande parte da população. Vale focar em reequilibrar as demandas do sistema, e vislumbrar maneiras de reconectar as áreas urbanas, peri urbanas e rurais, para promover o acesso à alimentação de qualidade em todas as esferas (Foodsystems, 2020).

A respeito da questão do consumo, Carlo Petrini considera que a tomada de responsabilidade pelas escolhas alimentares, face a todas as consequências sociais e políticas que isso representa, é um caminho longo, mas que começa a ser esboçado. A valorização do alimento bom, limpo e justo proposta pela Slow Food em oposição à padronização do gosto e supressão da cultura gastronômica, avançou muito nos quase 30 anos do movimento (Petrini, 2016).

"As pessoas estão prontas para desempenhar novo papel e quem não está, logo deverá estar, por necessidade, porque o sistema atual é insustentável, já está vacilante e é insatisfatório tanto para o consumidor como para o produtor." (Petrini 2010).

A opção pelo local é determinante para a sustentabilidade. Todas as vertentes passam pela origem da comida, sejam opções de dieta, financeiras, relacionais. "Focados tanto em uma nutrição saudável para si, como em uma relação mais sustentável para o meio ambiente, o consumidor passa a olhar toda a cadeia produtiva, fazendo escolhas mais criteriosas". (Food Biz Brasil, 2019). A rastreabilidade e consequente valorização da origem traz consigo a percepção clara dos custos imediatos e de longo prazo. Ficam palpáveis, objetificadas, todas as questões envolvidas ao longo da cadeia produtiva, e a escolha se torna mais precisa.

Petrini (Dumitru et al., 2016) chama esse consumidor consciente de prosumer (producer + consumer), que significa transcender o posto de consumidor passivo, que apenas recebe o que o mercado oferece, passando a interagir e influenciar as dinâmicas comerciais, sentir-se parte de uma comunidade, construir relações com os produtores de seu alimento, promover a economia local, estimular a ética nas relações humanas e com a natureza. Quando o consumidor toma a responsabilidade das consequências de suas decisões de compra, ele tem a chance 
de beneficiar diretamente os produtores, fortalecer práticas comunitárias e vínculos de confiança (ReLAFD, 2020).

Esse consumo positivo, que recompensa com a compra de produtos ou serviços os valores assegurados por uma empresa/negócio, o chamado buycott ${ }^{40}$ (Neilson, 2010), anda de braços dados com novas dietas que consideram seu impacto global, como o "reducionismo", o "flexitarianismo", o "climatarianismo", e com estruturas comerciais alternativas, de comércio justo, como os modelos de economia solidária, colaborativa, feiras, coletivos (Goodman, Dupuis \& Goodman, 2012). O poder que o consumidor possui em suas escolhas diárias, quando exercido com consciência e responsabilidade "é um dever, um ato de civilidade, em relação a si próprios, às próprias famílias, às próprias comunidades e aos próprios povos"; afirma Carlo Petrini (2010), que pontua que o consumidor precisa deixar de ser cúmplice da devastação ambiental em curso.

Relatórios de órgãos direcionados ao mercado da alimentação apontam que é crescente a prática do consumo consciente, com indivíduos que questionam o porquê e o que comem, a origem, a sazonalidade, os processos e atores envolvidos (Araium, 2020). De compras coletivas on-line, passando por CASs e hortas urbanas, é cada vez maior o número de soluções inovadoras, coletivas em que consumidores participam ativamente do encurtamento das cadeias de consumo de alimentos, e são capazes de efetivamente transformar o sistema alimentar de uma comunidade ou região (Jégou, Bala \& Manzini, 2008).

O mercado, ao perceber que há um contra movimento por parte do cliente, posiciona-se pela valorização do fresco, do local, acomoda sua produção, orientada pelas reivindicações do consumidor, e se atualiza, se modifica. As demandas de consumo orientam a produção, e são capazes de remodelar o sistema vigente (Goodman, Dupuis \& Goodman, 2012).

"Se queremos mudar o sistema alimentar, precisamos mudar o modo como produzimos e consumimos a comida ${ }^{41 " ~(B a r b e r, ~ 2015 b) . ~}$

\footnotetext{
40 Trocadilho anglófono, em um contraponto com boycott (boicote).

41 "If we're going to change the food systems, we've got to change how we grow and consume."
} 


\section{Método de Pesquisa}

\subsection{Design Science Research}

Como método de pesquisa, foi adotada a Design Science Research (DSR), que se propõe a trazer soluções satisfatórias para situações reais, já existentes, com o objetivo de alcançar melhores resultados para um problema. A proposição está calcada no uso da tecnologia para a criação de um artefato, seja ele tangível ou intangível; e têm o intuito de produzir soluções que sejam particulares ao problema, mas ao mesmo tempo generalizáveis, contribuindo para o estado da arte do campo do Design. "A Design Science não se preocupa com a ação em si mesma, mas com o conhecimento que pode ser utilizado para projetar as soluções" (Van Aken, 2004, p. 228).

As pesquisas que esperam como resultados a construção de um artefato e sua avaliação têm na Design Science Research o respaldo metodológico necessário. A avaliação pode ocorrer artificialmente, utilizando-se por exemplo simulação computacional e experimentos em campo. Essa avaliação "deve expor evidências de que o artefato, efetivamente, pode ser utilizado para resolver problemas reais" Lacerda et al., 2013). Nesta pesquisa, tal etapa será realizada de maneira experimental com o grupo de foco, com simulação de dados e foco na usabilidade.

Sinteticamente, as características fundamentais da DSR são assim apresentadas por Lacerda et al. (2013):

- Objetivos: prescrever e projetar artefatos que permitam soluções satisfatórias aos problemas práticos;

- Principais atividades: conscientizar, sugerir, desenvolver, avaliar e concluir;

- Resultados: artefatos

- Tipo de conhecimento: como as coisas deveriam ser;

- Papel do pesquisador: construtor e avaliador do artefato;

- Base empírica: não obrigatória;

- Colaboração Pesquisador-Pesquisado: não obrigatória;

- Implementação: não obrigatória;

- Avaliação dos resultados: aplicações, simulações, experimentos;

- Abordagem: qualitativa e/ou quantitativa

O processo do DSR é iterativo, e a retroalimentação das fases traz consigo oportunidades de avaliar e validar as ideias propostas. 


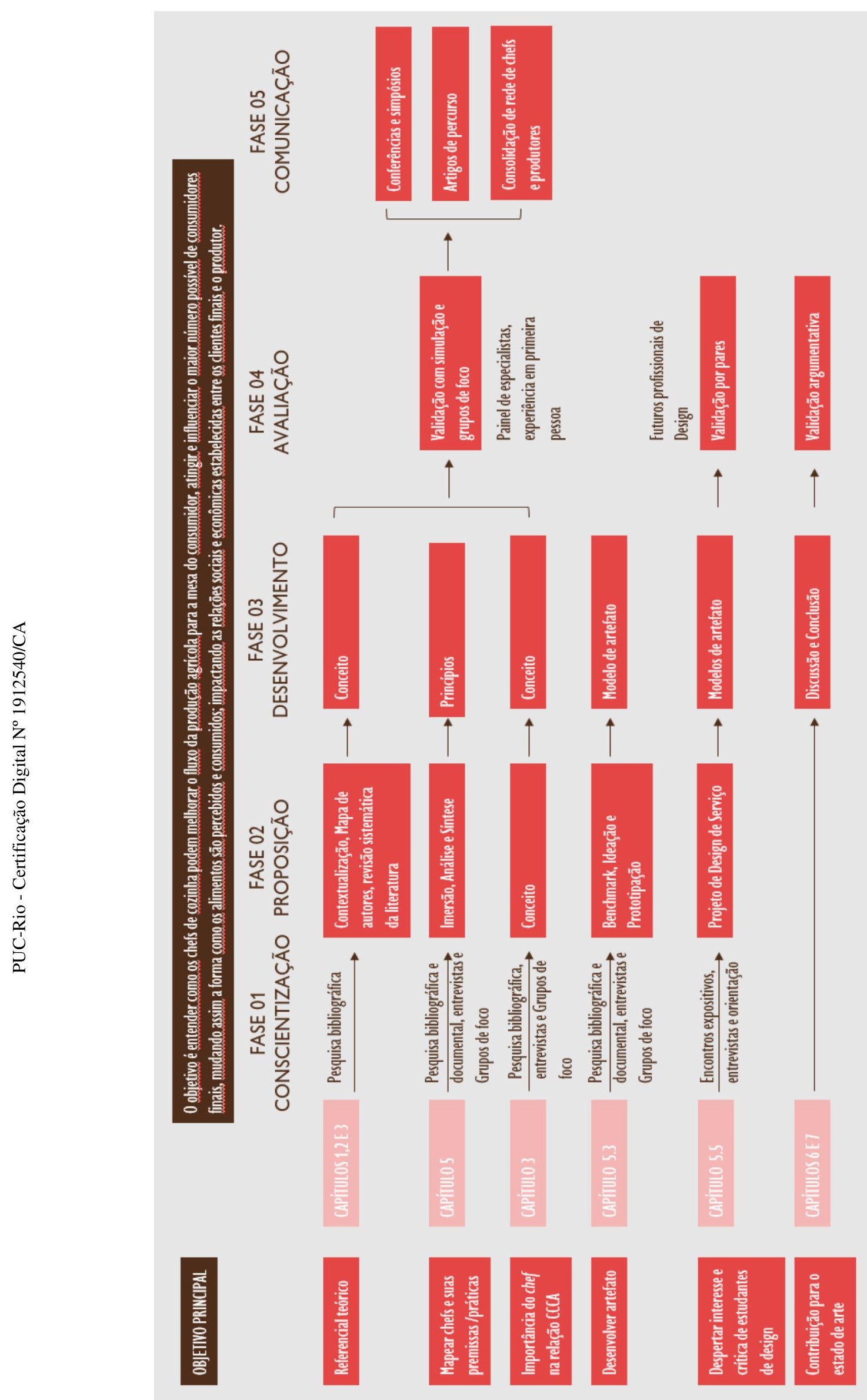


A primeira fase, de conscientização, consiste na coleta de informações sobre os temas relacionados de Design, comida/alimentação e Food Design, com um levantamento bibliográfico e uma série entrevistas e sessões coletivas de discussão, apoiadas pela metodologia Delphi. Aproxima-se nessa etapa do objeto de estudo, com o intuito de compreender as questões existentes e embasar o entendimento inicial do problema.

Durante a segunda fase, de proposição, serão elaborados conceitos e princípios para o serviço a ser criado. Nessa fase ainda, define-se o escopo do projeto de serviço, e, como processo cíclico e iterativo, são revistos e complementados os referenciais teóricos, consolidando-se a ideia do artefato ou serviço a ser criado.

Posteriormente, o trabalho se debruça sobre a identificação das necessidades e oportunidades, norteando a geração de soluções projetuais (Vianna et al., 2012). Inicia-se o desenvolvimento do projeto, baseado nos modelos entendidos a partir da imersão, análise e síntese das fases anteriores. Como caminho complementar, os conceitos iniciais são apresentados a futuros profissionais do Design, que desenvolvem artefatos baseados no cenário exposto/revisado.

$\mathrm{Na}$ fase 4 o artefato passa por uma avaliação, com simulações de uso e debates com o painel de especialistas, em grupos de foco. Ideias dos graduandos de Design são igualmente apresentadas e avaliadas, configurando uma validação por pares. Uma análise global dos resultados atingidos conclui a fase de avaliação, dando sequência para a fase 05 , de comunicação.

Na última etapa, serão publicizados os resultados do processo de pesquisa e projeto desenvolvidos, com artigos e apresentações em eventos relacionados ao Food Design, Design e sustentabilidade.

Vale ressaltar a não linearidade da DSR, com etapas de retroalimentação, análise e revisão acontecendo simultaneamente, ao longo de toda jornada.

A escolha metodológica nesse trabalho reflete os diferentes papéis desempenhados pela pesquisadora, designer e investigadora. Estar enredada nas questões estudadas colocou a pesquisadora como particularmente interessada no desenvolvimento e resultados, e a condução enviesada não é vista aqui de maneira pejorativa. Ao contrário, a pesquisadora e os colaboradores utilizam a mesma linguagem, e isso cria melhores condições para desenvolver soluções mais próximas do seu fazer profissional, no que tange à compreensão, sustentabilidade e aplicabilidade da pesquisa. 
Outras metodologias podem contribuir com a construção de artefatos na DSR em contextos particulares, como no caso desta pesquisa, como a Pesquisa-ação Participante, Food Design Thinking, Design Thinking e Design de Serviço, apresentados brevemente nos subcapítulos que seguem.

\subsection{Pesquisa-ação Participante}

A pesquisa-ação contribui na conexão dos campos de teoria e prática, que muitas vezes não coexistem. Por ser feita de forma participativa, tem o pesquisador inserido no campo de pesquisa, ultrapassando a descrição ou compreensão do fato para interferir na realidade observada, de modo colaborativo. São propostas por Baskerville \& Wood-Harper (1996) seis etapas para essa prática: análise, procura por fatos, conceitualização, planejamento, implementação da ação e avaliação.

"A Pesquisa-ação é um tipo de pesquisa social com base empírica que é concebida e realizada em estreita associação com uma ação ou com a resolução de um problema coletivo e no qual os pesquisadores e os participantes representativos da situação ou do problema estão envolvidos de modo cooperativo ou participativo." (Thiollent, 1986, p.14).

Segundo Sagor (2000), o método deve focar nas necessidades dos usuários e na melhoria de suas práticas, em seu próprio contexto, utilizando-se de estudos de grupo, análise das necessidades e do impacto das soluções propostas; não sendo um processo linear, em que se pode reconsiderar e replanejar ao longo do processo.

Pesquisa-ação Participante baseia-se também em estudar a prática profissional para torná-la mais racional, mais produtiva e sustentável; mais justa e inclusiva (Kemmis, Mctaggart \& Nixon, 2014). O que é fundamental na metodologia é a participação imersiva em todas as etapas da pesquisa, por pesquisadores que estejam envolvidos ativamente no campo do saber, focados no conhecimento da realidade, das peculiaridades cotidianas localizadas, e não nas abstrações, nas generalizações.

Lewin (2007) vislumbrou a necessidade de se criar um método que aproximasse pesquisadores e profissionais, unindo ação social e teoria social, e definiu o termo como:

"uma pesquisa comparativa das condições e efeitos de várias formas de ação social e pesquisa ligada à ação social. Esse tipo de pesquisa utiliza uma "escada em espiral", 
em que cada sequência de degraus corresponde à sequência de planejamento, ação e avaliação dos resultados da interação." 42 (Lewin, 2007, p. 223).

A Pesquisa-ação Participante se assemelha tanto à DSR quanto às metodologias de Design empregadas no presente estudo. Ela lança mão de suas etapas iterativas e orientadas à inovação para observar processos, ações e consequências da mudança; refletir sobre tais processos e consequências; replanejar; fazer nova observação participante, nova reflexão e assim sucessivamente. Além disso, a ideia é sempre envolver a comunidade de indivíduos/sociedade e seu entorno, colaborativamente, promovendo tanto mudanças locais, pessoais, quanto políticas e globais. É ter em mente que as mudanças no modo de fazer interferem na sociedade como um coletivo (Kemmis, Mctaggart \& Nixon, 2014).

\subsection{Design Thinking, Design de Serviço e Food Design Thinking}

"Convertendo necessidade em demanda, ou colocando as pessoas em primeiro lugar." 43 (Brown, 2009).

O design pode contribuir na proposição de maneiras pelas quais chefs de cozinha possam impactar positivamente as CCCA, com base no argumento de que o produto-serviço resultante de um processo de design busca representar os valores, dar significado e ferramentar a construção de relações baseadas no tripé da sustentabilidade, na ética, na educação e na formação de um processo de consumo mais consciente. Como explicado por Verganti (2012), quando o design vai além do usuário, da investigação de suas necessidades, ele se coloca como um processo de inovação em que compreende o meio sociocultural envolvido, o contexto de vida que pretende explorar, e assim definir os significados e valores que quer enaltecer (Zampollo, 2013a).

Georges Romme (2003) divide os campos de pesquisa em ciências - baseada em consenso objetivo e leis generalistas; humanidades - que procura entender os fenômenos e práticas sociais através das narrativas dos atores envolvidos; e design focado em produzir sistemas que ainda não existem, por meio de mudanças nas

\footnotetext{
42 "A comparative research on the conditions and effects of various forms of social action and research leading to social action. This type of research uses "a spiral step," each of which is composed of a circle of planning, action and fact-finding about the result of the action."

43 "Converting need into demand, putting people first."
} 
práticas e situações sociais, envolvendo os campos da engenharia, arquitetura e planejamento em geral.

Enquanto a Pesquisa-ação Crítica Participante é consensualmente tida como um método de pesquisa, o Design Thinking e o Design de Serviço são considerados tanto uma metodologia quanto um processo projetual de inovação que envolvem diversos métodos de pesquisa. Embora o termo tenha sido cunhado cerca de duas décadas depois da consolidação da Pesquisa-ação, muitos conceitos e processos são similares, particularmente quando o processo é crítico e participativo.

Design Thinking é um termo que começou a ser utilizado nos anos '90, tendo sido empregado largamente nas últimas décadas. É aplicado nos mais diversos setores, visto como uma estratégia, uma metodologia ou um conjunto de técnicas para abordar problemas complexos que são mal definidos ou desconhecidos, também chamado wicked problems, definidos por Rittel como

"[...] um grupo de problemas de sistemas sociais que são mal formulados, em que a informação é confusa, em que há muitos atores com conflitos de valor envolvidos, e em que as ramificações do sistema são absolutamente confusas." ${ }^{44}$ (apud: Buchanan, 1992).

Para Tim Brown (2008) essa abordagem utiliza capacidades que nem sempre são consideradas nos métodos tradicionais de resolução de problemas, e que são tipicamente centradas nas características humanas de intuição, capacidade de reconhecer padrões, construir ideias funcionais com fundo emocional e se expressar de maneiras distintas da linguagem formal. No livro "Isto é Design Thinking de Serviços", Stickdorn \& Schneider (2014) falam do processo de pensar projetualmente, enquadrando os problemas de forma criativa, com um olhar holístico e multidisciplinar, gerando soluções muitas vezes inusitadas, que se adaptam aos novos modelos, formas de organização e prestação de serviços que a sociedade apresenta.

Brown (2008) diz que a missão do Design Thinking é transformar as observações em ideias e ideias em produtos e serviços que irão melhorar vidas. Outro designer que aborda esses conceitos é Manzini, que diz:

"Design é a cultura e prática relacionadas à maneira em que as coisas devem ser ordenadas, para que se atinja as funções e significados almejados. O design se dá por processos abertos de co-design, nos quais todos os participantes são envolvidos de alguma maneira. [...] Essa descrição deve ser acrescida ainda de outra observação: na

44 "a class of social system problems which are ill-formulated, where the information is confusing, where there are many clients and decision makers with conflicting values, and where the ramifications in the whole system are thoroughly confusing." 
transição para uma sociedade conectada e sustentável, todo design é (ou deveria ser) uma atividade de pesquisa pelo design, promovendo experiências sociotécnicas." 45 (Manzini. 2015, p. 48).

Em estudo feito por Pacenti e Sangiorgi (2010) foi identificado que inicialmente o Design de Serviço explorava a natureza dos serviços (ou produtosserviços), e três áreas principais emergiram dessa nova abordagem do design: o campo do Design de Serviço propriamente dito, o Sistema Produto-Serviço (PSS, ou Product-Service System) e o Design para Inovação Social e Sustentabilidade. Conforme as autoras, as áreas compartilham interesses comuns no desenvolvimento metodológico e ferramental, tanto no campo da prática quanto da teoria (Pacenti \& Sangiorgi 2010).

O Design de Serviço materializa essa abordagem intangível do Design, projetando situações ou soluções que não estão vinculadas à produtos, mas sempre centradas nas necessidades e demandas do usuário. A ideia é problematizar a situação, com um olhar macro que veja além do problema em si. O processo de design é dividido entre definição do problema e solução do problema. Tanto o Design Thinking quanto o de Serviço pressupõem ênfase nas soluções centradas no usuário (humano), que gerem inovações; e sejam co-desenhadas, trabalhadas de forma participativa (Brown, 2008; Stickdorn \& Schneider, 2014; Vianna et al. 2012, 2018; Zampollo, 2018).

Novos perfis de consumidores impulsionam a criação de novas relações, conceitos e inovações, que atendam esse usuário, cada vez mais atento, consciente do seu papel nas demandas de mercado, seja ele de bens, seja de serviços (educação, cultura, lazer, alimentação, segurança, saúde etc.). Para os autores, o design de um serviço

"se refere ao processo de design a não ao seu resultado final. O resultado de um processo de design de serviços pode assumir diversas formas: desde estruturas organizacionais relativamente abstratas, processos operacionais, experiências de serviços até objetos fisicamente concretos." (Stickdorn \& Schneider, 2014, p.16).

Mesmo com vasto ferramental para o processo de Design Thinking, Francesca Zampollo propõe a discussão da especificidade dos campos, e lança um método específico para tratar de problemas que relacionem comida e design, o "TED

45 "Design is a culture and a practice concerning how things ought to be in order to attain desired functions and meanings. It takes place within open-ended co-design processes in which all the involved actors participate in different ways. [...] This description must be augmented with one further observation: In the transition toward a networked and sustainable society, all design is (or should be) a design research activity and should promote sociotechnical experiments" 
Themes for Eating Design" (Zampollo, 2014), em outras palavras, o Food Design Thinking. Ela baseia seus conceitos em reconhecidos autores do Design Thinking, e enaltece ainda o processo de Osborn (1953, apud Zampollo, 2014), que apresenta de maneira clara e simples o raciocínio do designer para a solução de problemas em três etapas: encontrar o Fato, encontrar a Ideia e encontrar a solução.

A designer acredita que é preciso superar a geração de métodos genéricos, que não prescindem necessariamente da sustentabilidade, com métodos desenhados especificamente para trazer inovações econômica-socialambientalmente sustentáveis na alimentação; assim como já é possível encontrar processos tão específicos quanto os descritos no livro "Isto é Design Thinking de Serviços" de Stickdorn \& Schneider (2014).

$\mathrm{Na}$ metodologia apresentada, o interesse é sempre um artefato (produto ou serviço) relacionado à alimentação; baseado na criação de proposições que sejam significativas para as pessoas e para o planeta, focadas nos três pilares da sustentabilidade e na criação de valor e significado. Serão sempre contemplados os aspectos da empatia, experiência do usuário e do pensamento sistêmico no processo de design. O FDT se divide em seis fases e múltiplos processos, descritos na figura 21, apresentada na página 90.

\subsection{DELPHI}

A metodologia DELPHI consiste na troca de informações e opiniões dentro de um grupo de especialistas, na qual diversas rodadas de perguntas, síntese e discussão são aplicadas, de forma interativa, até se chegar a um consenso. Esta metodologia, com intervenções estruturadas, que fomenta a aprendizagem mútua, se vale da existência de um problema incerto e mal definido (tratado pelo Design Thinking como wicked problem) e da coleta de informações intuitivas, experiências profissionais, que podem ser tanto qualitativas quanto quantitativas (Cuhls, Blind \& Grupp, 2001).

Não há uma fórmula padrão de se aplicar a metodologia, desde que sejam seguidos os preceitos de ao menos duas rodadas de perguntas seguidas de discussão dos resultados analisados e sintetizados, e que se mantenha o anonimato das opiniões, para que se chegue a um veredito sem influenciar individualmente o discurso (Turoff et al., 2002). Esta dependência direta da qualidade e da quantidade dos conhecimentos dos participantes torna particularmente relevante e sensível a escolha, motivação e acompanhamento do painel de participantes. 


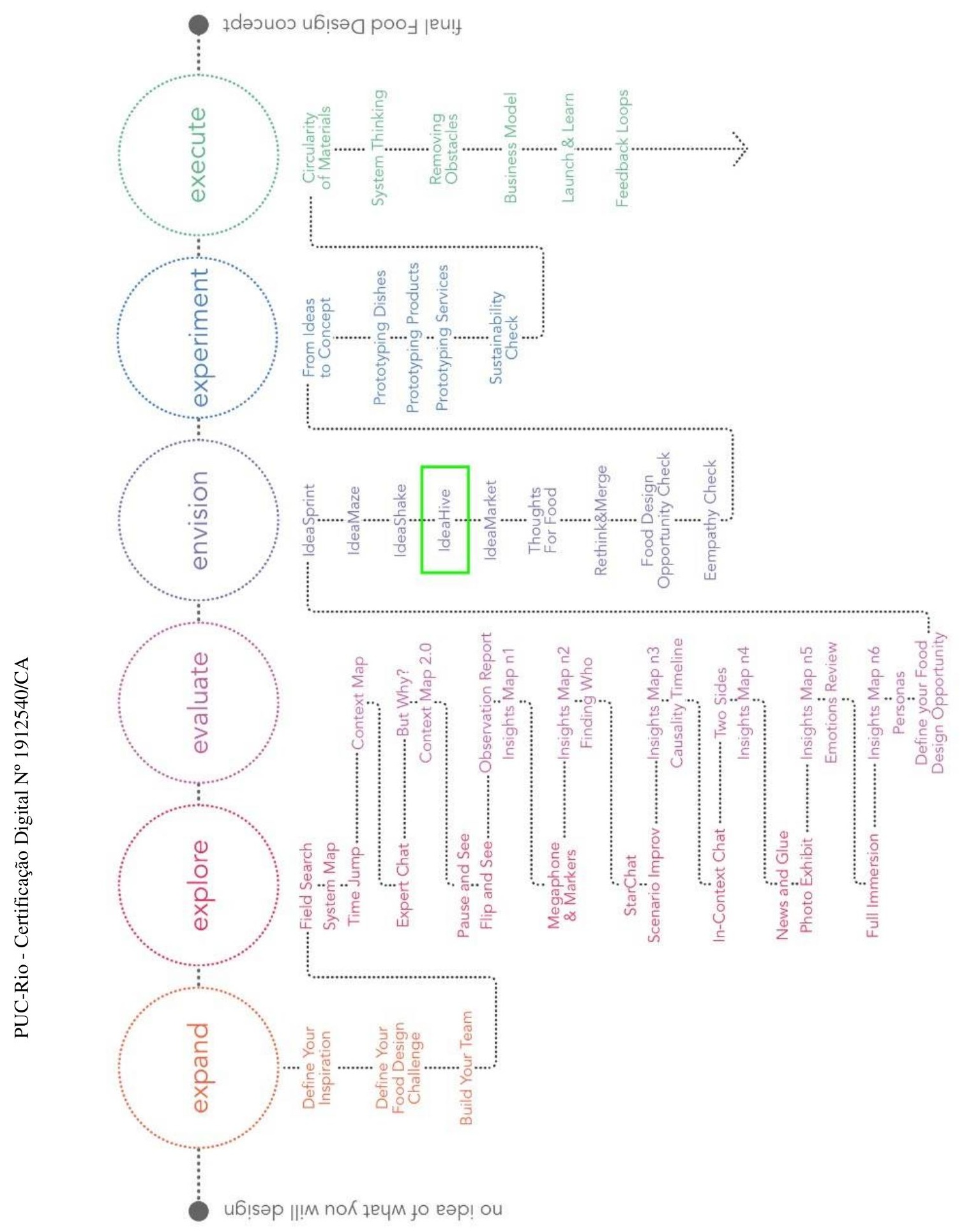

Figura 21 . Food Design Thinking Methodology. (Zampollo, 2014). 


\section{Resultados}

A proposição de serviço apresentada, se desenvolveu sobre as premissas da Design Science Research, culminando no desenvolvimento de um artefato (serviço). O desenvolvimento das etapas da pesquisa se valeu do ferramental disponível para as quatro fases iterativas do Design Thinking: Imersão, Análise e Síntese, Ideação e Prototipação, preconizadas pelo manual da MJV (Vianna et al., 2012).

O estudo abordou paralelamente dois eixos de Design de Serviço: o primeiro, realizado pela pesquisadora no papel de designer, em um processo de full immersion ${ }^{46}$ (Zampollo, 2014); e outro, desenvolvido por alunos da graduação na UFRJ, na disciplina de Design de Serviço ministrada pela professora Carla Cipolla, tendo a pesquisadora como convidada.

Ambos os exercícios versam sobre o estudo das relações entre chefs, produtores e consumidores, a sustentabilidade de suas práticas e consumo consciente. A resposta para os desafios identificados é a proposição de um sistema mais justo, sustentável e resiliente para os atores. Os obstáculos enfrentados abarcam a relação dual entre chefs de cozinha e pequenos produtores; e a transmissão e apreensão de valor entre consumidor final e os demais integrantes da cadeia.

\subsection{Imersão Preliminar e Imersão em Profundidade}

Nessa fase se entabula a aproximação com o objeto de estudo, no intuito de compreender melhor as questões e embasar o entendimento inicial do problema, para posteriormente identificar necessidades e oportunidades que irão nortear a geração de soluções nas fases seguintes do projeto. Foi dividida em etapas que aprofundam gradativamente a empatia pelo usuário, utilizando um ferramental que abarcou desde entrevistas e sessões generativas com usuários e atores selecionados, até momentos de vivência.

O foco nessa fase foi de identificar as dinâmicas, os pontos de contato mais relevantes, as dificuldades e oportunidades dos atores (Sanders \& Simons, 2009; Stickdorn \& Schneider, 2014). Além da pesquisa exploratória, a vivência profissional pessoal da autora, com experiência em cozinhas de restaurantes de diferentes

\footnotetext{
46 Imersão total
} 
países, promoveu imersão participativa em primeira pessoa, e foi adicionada para destacar os pontos importantes do processo.

\subsubsection{Imersão Preliminar. Pesquisa Desk}

Para dar início a esse trabalho, foram levantadas qualitativamente pesquisas recentes (conferências, dissertações/teses e artigos científicos) relevantes ao tema e bibliografia de referência que relacionassem de alguma forma a disciplina do Design com alimentos/alimentação/comida/comer.

Foram, da mesma forma, revisados os principais autores dentro das subcategorias do Design que de diversas maneiras perpassam o assunto da alimentação, como Design de Sistemas, Design Sustentável, Design de Serviço, Design Thinking e Design para Inovação Social. A síntese dos autores mais relevantes na pesquisa é apresentada na Figura 22 . Mapa de autores.

Em seguida, uma revisão sistemática da literatura buscou pinçar fatos relevantes sobre comida/alimentação e as relações de sustentabilidade diretamente envolvidas nesse sistema. Na última década esse tema aparece como constante preocupação dos órgãos internacionais como ONU, FAO; das ONGs como a Fair Trade Foundation, de fóruns relacionados a alimentos, agricultura e meio ambiente; governos e iniciativa privada de modo geral, e até mesmo da World Design Organization, que tem como uma de suas principais pautas as questões de impacto social e ambiental traçadas pelos Objetivos de Desenvolvimento Sustentável da ONU.

Tais entidades, juntamente com seus trabalhos e resultados de pesquisadores colaboradores, proporcionaram material para uma compreensão mais profunda e abrangente das questões que envolvem as cadeias de produção de alimentos. Adicionalmente, foi feito um breve apanhado de autores que tratam das relações de consumo e produção, particularmente no universo da alimentação como fenômeno sociológico. 


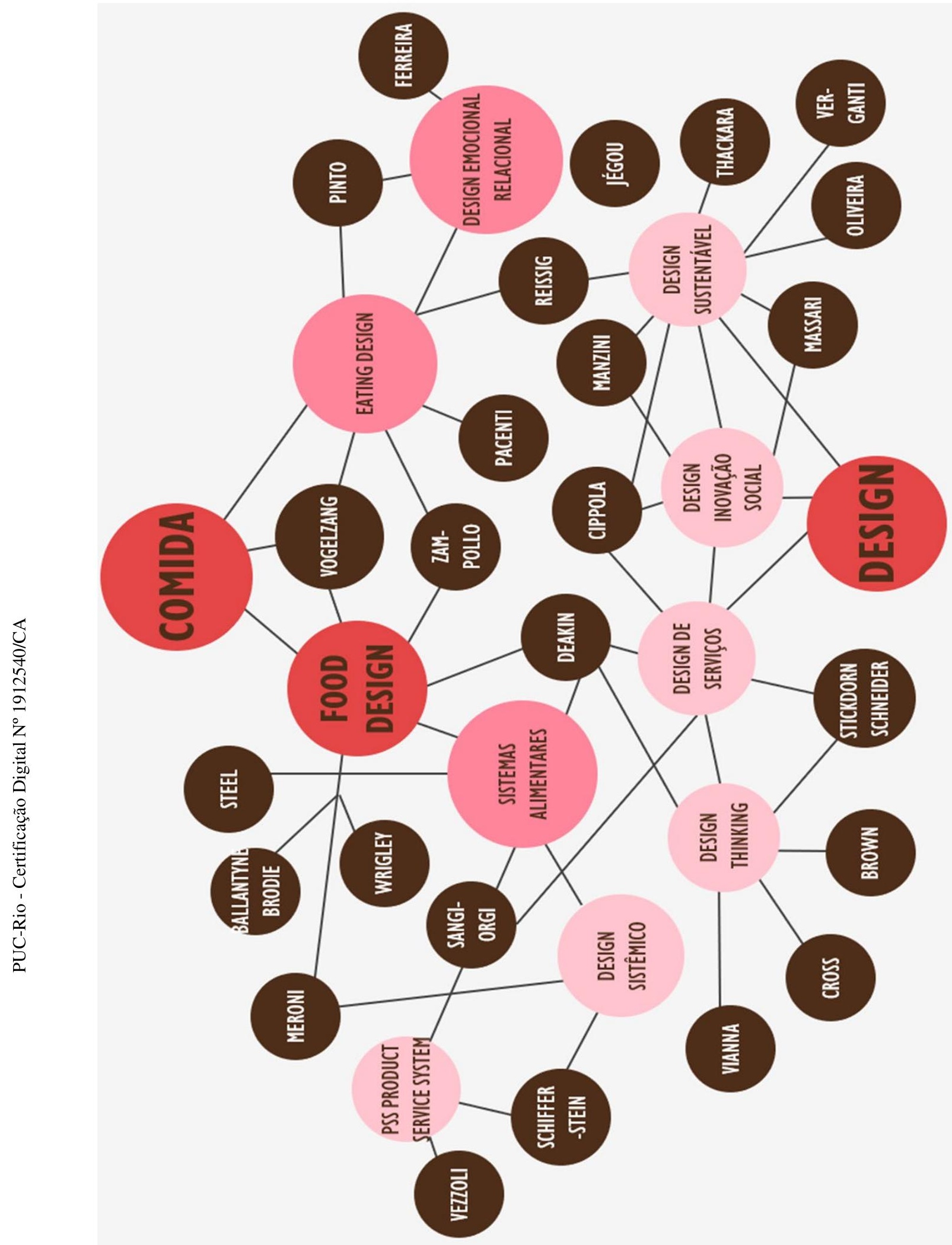

Figura 22 . Mapa de autores.

A revisão sistemática da literatura resultou também em um mapa de literatura da pesquisa (Creswell, 2007), com tópicos que foram categorizados nos macrocampos de Design, Alimento e Food Design, e nos campos mais específicos de 
sustentabilidade, cadeias curtas de consumo de alimentos, consumo consciente, inovação social, Design Colaborativo/Relacional, Design Thinking, Design de Serviço, Design Sistêmico, artes e sociedade. O quadro Anexo 01. Mapa de literatura da pesquisa apresenta esse mapeamento bibliográfico.

\subsubsection{Imersão em Profundidade}

No intuito de explorar o contexto de interesse, aprender sobre o espaço da investigação e coletar informações existentes, essa etapa conta com a imersão na comunidade de atores envolvida no tema da pesquisa. Nessa fase, o entendimento sobre o assunto se aprofundou, ao passo que crescia a empatia pelos envolvidos no contexto de interesse. As etapas desta fase interagiram e foram retroalimentadas pela fase de Análise e Síntese (capítulo 5.3) e seus produtos. Para projetos de Food Design, é de suma importância a imersão total no universo do usuário, para que haja empatia sensível, não só sentindo o que o outro sente, mas sendo igualmente impelido a interferir, ajudar (Zampollo, 2013a).

No processo imersivo, foram identificadas muitas iniciativas em curso, que potencializam a territorialidade dos hábitos alimentares, práticas agrícolas e biodiversidade regionais. Com mecanismos de aproximação entre o campo e a mesa, prosperam as economias locais, amplia-se o acesso aos alimentos frescos, sensibiliza-se o paladar, valoriza-se, em suma, todo o ciclo de produtos e serviços envolvidos na cadeia curta de produção e consumo de alimentos (Manifesto Local, 2018; Desmet \& Hekkert, 2007).

Inicialmente, foi feita uma triagem de chefs expoentes brasileiros e cariocas, para conhecer a origem dos alimentos utilizados em suas cozinhas, bem como os fatores que influenciam a escolha e o que essa preferência acarreta na cadeia de consumo. Com base nessas informações, foi possível circunscrever a área a ser pesquisada com mais foco. A seleção dos participantes se deu, portanto, pela relevância de sua contribuição na área da gastronomia, pertinência de princípios e práticas nas operações cotidianas e as possibilidades de se detectar pontos a serem valorizados no futuro, como prioridades, dificuldades e oportunidades. A partir do perfil identificado e as interações realizadas, foi desenhado o Mapa de Atores. Na cadeia curta de consumo de alimentos em restaurantes, foram identificados três atores mais relevantes para esse estudo, envolvidos de maneira direta: o produtor, o chef de cozinha e o consumidor final. 


\section{Cliente do Restaurante}

\section{Brigada da cozinha}

\section{Proprietário/Sócio}

Restaurante

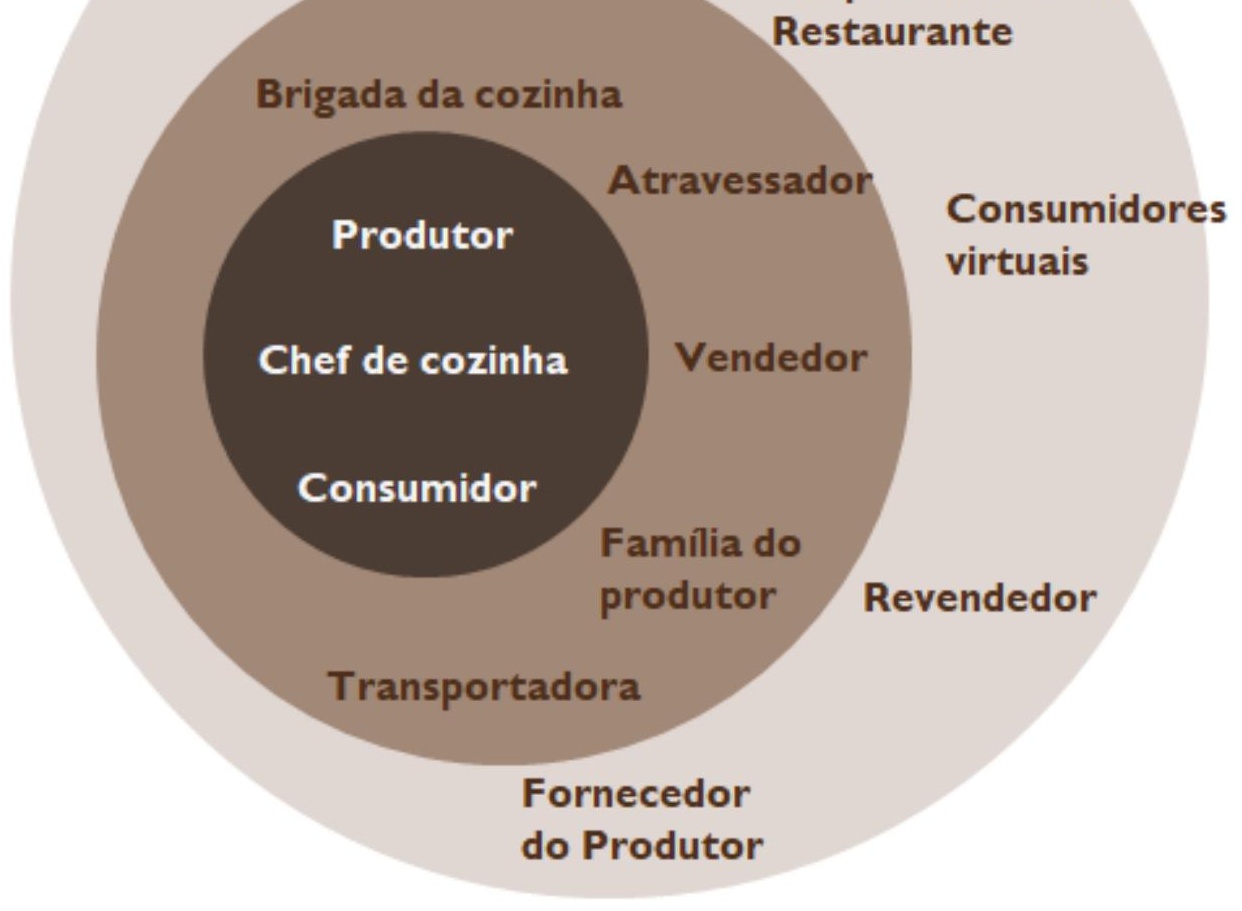

Figura 23. Mapa de atores.

Objetivando levantar dados qualitativos sobre os processos e relacionamentos entre os atores da cadeia, um questionário inicial de perguntas semiestruturadas foi elaborado. Os participantes foram previamente informados sobre o caráter das atividades, e receberam em mãos ou por e-mail o Termo de Consentimento (Anexo 02), dando ciência e confirmação de sua participação. A cooperação na pesquisa foi realizada de forma anônima, tendo sido atribuídos aos integrantes das entrevistas e dos painéis de discussões uma nomenclatura alfa numérica (Chef 01 a 13, Empreendedor 01 e 02, Produtor 01 a 05).

Foram elencados dez chefs para a etapa de entrevistas, alguns inclusive com experiência adicional em consultoria e pesquisa acadêmica. As entrevistas ocorreram entre julho de 2019 e julho de 2020, ora individualmente, ora coletivamente, para engrandecer o debate (Grupo de Foco ${ }^{47}$ ). Os questionários foram respondidos em

47 "a question of thinking or doing, but what to think about and how to do" 
encontros presenciais, de forma escrita, ou ainda via áudio/vídeo gravado (situações propiciadas em alguns casos pelo isolamento social do COVID 19).

Para compor o cenário, também foram convidados para entrevistas e grupos de discussão cinco pequenos produtores e dois empreendedores engajados com produtos locais inseridos no mercado de relevância nacional que trabalham com cadeias curtas fora do Rio de Janeiro. Estes integrantes tiveram anonimato e nomenclatura aplicados de maneira análoga a do grupo anterior.

O painel de especialistas entrevistados foi composto segundo características fundamentais para a pesquisa, como relevância no cenário gastronômico local, familiaridade com o uso de ingredientes de origem local ou rastreável, restaurantes e produtores de pequena escala com público consumidor de perfil econômico $A / B$. As dinâmicas foram realizadas nas próprias dependências dos restaurantes ou em seminários on-line.

No segundo semestre de 2020 foram convocados seminários on-line com os chefs previamente entrevistados. Os webinários foram instrumentados pela metodologia DELPHI, que em diversos momentos tangencia, ou mesmo se mescla com os processos de Design abordados na pesquisa, sendo por definição iterativos e participativos.

As perguntas semiestruturadas direcionaram o foco para a rotina de funcionamento da cozinha no tocante à elaboração de cardápios, pedidos/compra/entrega de insumos, aceitação do público e questões financeiras. Em um segundo momento, foi abordado o tópico de responsabilidade e influência social dos chefs. O conceito da metodologia foi aplicado parcialmente na fase de Sessões Generativas, uma vez que após o primeiro encontro os participantes foram revelados. A questão propulsora da fase de Imersão em Profundidade, conduzindo as entrevistas e etapas seguintes, teve a seguinte indagação como pano de fundo e direcionamento: partindo da premissa que os chefs com visibilidade midiática (geralmente de alta gastronomia) têm influência nos padrões de consumo, e com isso, responsabilidade na sociedade, como eles podem intervir na cadeia de produção/comercialização e impulsionar o consumo consciente de alimentos? Subsequentemente, foram propostas outras 5 indagações, conduzindo a respostas mais assertivas: 


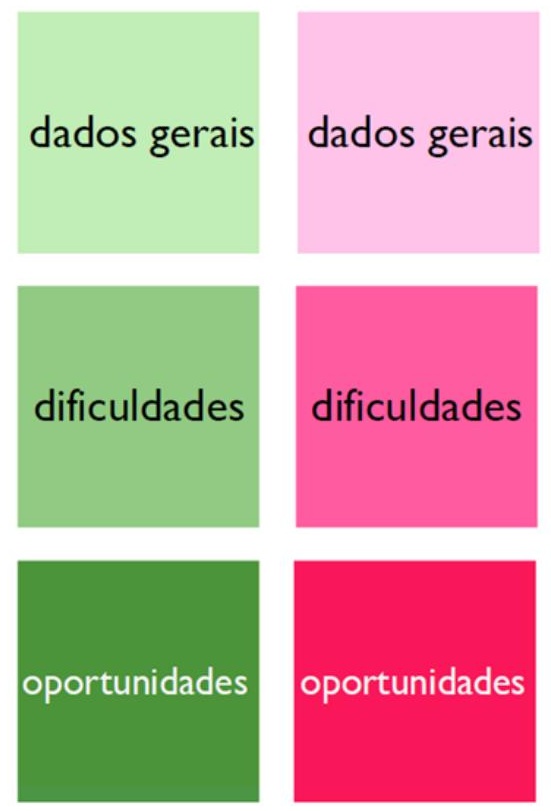

I. Qual o papel do chef de cozinha no encurtamento das cadeias de produção e consumo de alimentos?

2. Como o chef pode melhorar a conexão entre o produtor e o consumidor?

3. O chef tem papel de educar o consumidor? Como? Com que ferramentas?

4. Quais são os benefícios e obstáculos de se trabalhar com pequenos produtores? Vislumbrando os canais produtor-chef/ restaurante e chef/restaurante-consumidor final

5. De que maneira esses obstáculos poderiam ser resolvidos?

Figura 24 . Questionário aplicado para produtores e chefs

Embora a considerável prática da pesquisadora como chef de cozinha forneça suporte para diversas questões ligadas a essa discussão, a técnica de "Um dia na vida" (Vianna et al., 2012) também foi utilizada, propiciando uma Imersão total ("Full Immersion" - Zampollo, 2014). Para essa atividade, foram realizados um total de quatro jantares no segundo semestre de 2019; dois no Rio de Janeiro e dois em Brasília.

Os jantares foram executados em parceria da pesquisadora com dois dos chefs participantes da etapa de Imersão, em seus restaurantes. Ambos os estabelecimentos trabalham sistematicamente com produtores parceiros e cardápios sazonais com foco em produtos locais e aproveitamento total. O cardápio foi inteiramente desenhado pelos três chefs, a partir de insumos locais e de pequenos produtores. O objetivo desse exercício foi vivenciar e oportunizar a possibilidade de acompanhar em minúcias o processo de decisões, compra, recepção dos insumos, preparo e divulgação/comercialização de um cardápio.

Os chefs foram convidados a realizar os jantares com a participação da pesquisadora, seguindo os princípios e práticas de cozinha habituais de ambos, que já possuem uma rede parceira de pequenos produtores. Os eventos aconteceram em dois finais de semana, com cardápio explorando cada território, agregando a bagagem cultural dos três chefs, e voltado inteiramente para a disponibilidade dos produtos, conforme prática habitual de seus restaurantes. Os chefs participantes 
iniciaram a elaboração do menu com o levantamento dos insumos disponíveis no leque de fornecedores dos restaurantes anfitriões para planejar a composição do cardápio. O processo se repetiu nas duas cidades.

Escolhidos os ingredientes, os chefs definiram quantos pratos iriam oferecer, escolheram as técnicas de preparo e compuseram o menu, em cinco etapas (entrada, três pratos principais e sobremesa). Com esse primeiro desenho, puderam então precificar e divulgar o evento nas redes sociais, site e mailing de clientes. A venda antecipada é crucial para esse modelo de jantar, em que se garante a lotação da casa e a compra precisa de ingredientes.

Três dias antes do evento os chefs fizeram as compras, indo pessoalmente ao mercado do produtor para o hortifruti e parte dos produtos frescos, ao mercado de peixes, e pedindo os demais itens aos fornecedores habituais. Alguns insumos foram comprados ou recebido no dia do evento, pela perecibilidade.

De posse dos ingredientes, foram feitos os pré-preparos, e, no dia do jantar, as guarnições finais e execução da mise en place. Todos os pratos foram montados, fotografados e degustados pela equipe, para também serem harmonizados com os vinhos que seriam oferecidos nas duas noites. O menu foi então escrito e impresso para os convidados. Com essa característica de cardápio, é muito comum que os menus sejam escritos em quadros ou impressos diariamente, já que a produção é particular para cada ocasião. As mesmas etapas foram realizadas para os jantares no Rio de Janeiro e em Brasília, no fim de semana subsequente.

O serviço com o cliente é o momento no qual todos os atores da cadeia se encontram de alguma maneira, e o contato se dá, basicamente, pelas explicações do texto no menu impresso e pela interação com a equipe de atendimento. Durante e após o serviço aconteceu a divulgação nas redes sociais, com interação de clientes presentes e futuros. É também um importante momento de captação para outros eventos.

As impressões colhidas durante toda essa rotina confirmam as informações levantadas nas demais etapas da imersão. Para executar o cardápio de duas noites de jantar, os cozinheiros compraram insumos em cerca de 20 fornecedores, foram eles mesmos às compras, e receberam entregas em diversas horas, durante três dias. 

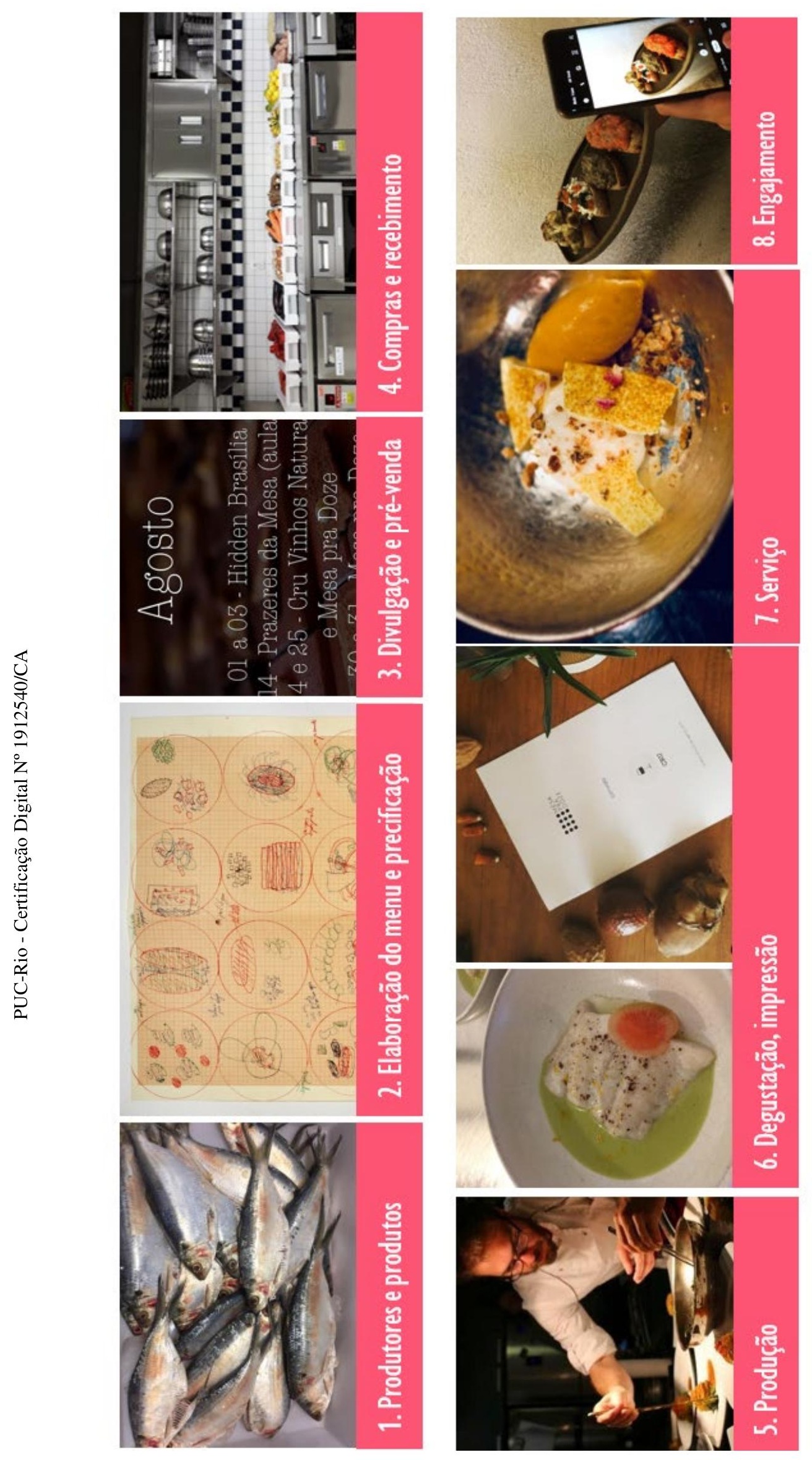

Figura 25. Storyboard "Um dia na vida" 2020. 


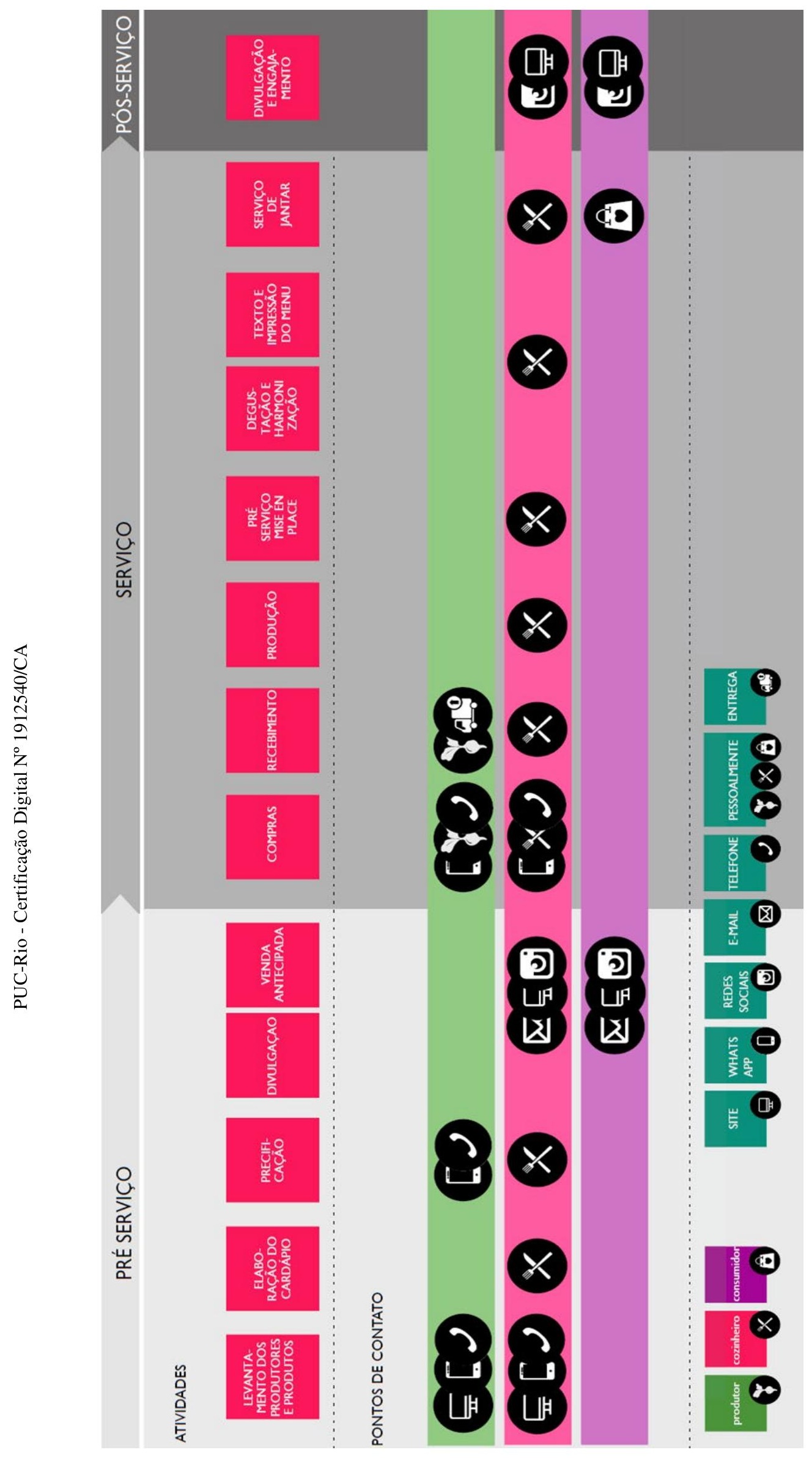

Figura 27 . Jornada do cozinheiro para o jantar harmonizado. 


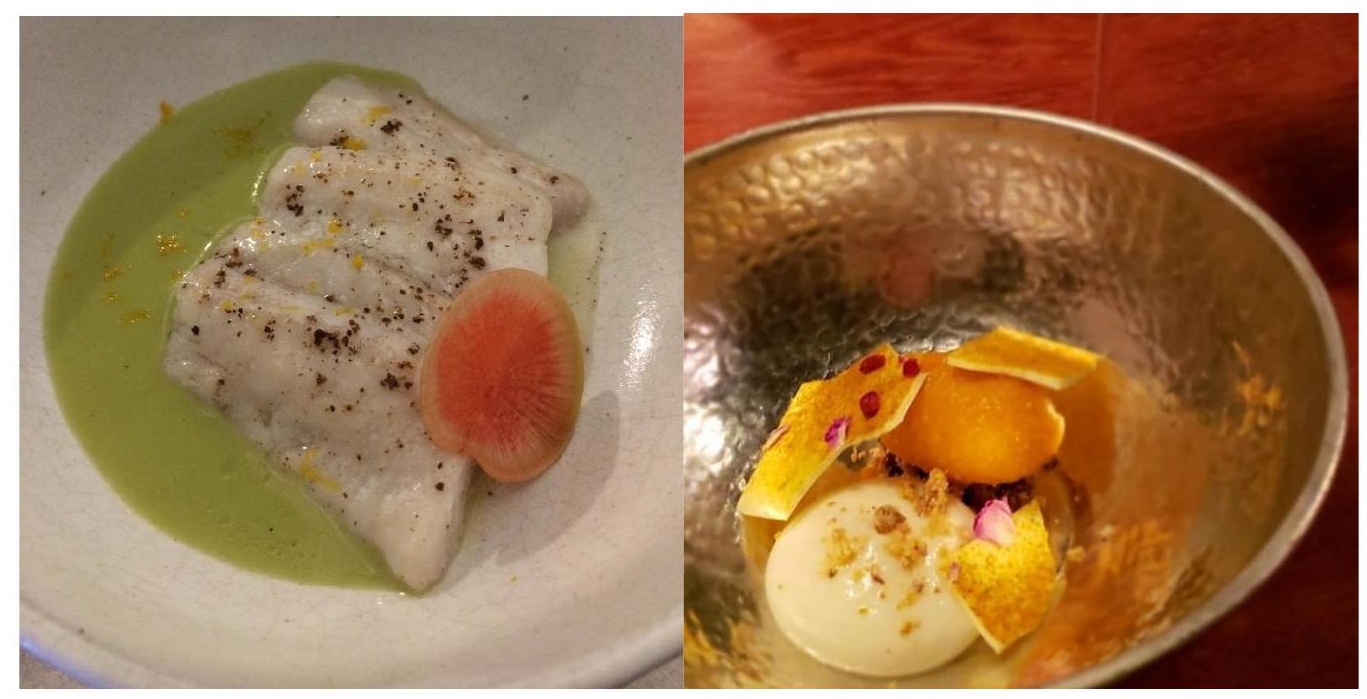

Figura 28 . Pratos dos jantares realizados

Paralelamente às reuniões com os cozinheiros e produtores, foi conduzida uma pesquisa com um grupo de consumidores durante os meses de junho e julho de 2020. Esse grupo foi submetido aos mesmos procedimentos de ciência e anonimato adotado para os grupos dos Produtores e Chefs. Os consumidores entrevistados para essa pesquisa seguiram um perfil socioeconômico compatível com o dos restaurantes selecionados. Para maior riqueza de diversidade nas respostas, foi elencado um conjunto de indivíduos de amplo espectro de etário, estado civil, com e sem filhos, mulheres e homens.

Escolhidos os participantes, foi enviado por e-mail o Termo de Consentimento (Anexo 02), dando ciência e confirmação de sua participação na pesquisa de forma anônima. A primeira abordagem solicitou que respondessem sobre seus hábitos alimentares de forma geral, para suscitar o interesse pelo tema. Em seguida foi aplicado um questionário mais longo (Anexo 04 . Questionário Consumidor), e que preenchessem um journal sobre sua rotina alimentar (Anexo 05 . Rotina dos entrevistados) abordando também questões pertinentes às mudanças trazidas pelo cenário do isolamento social imposto pelo COVID-19. 


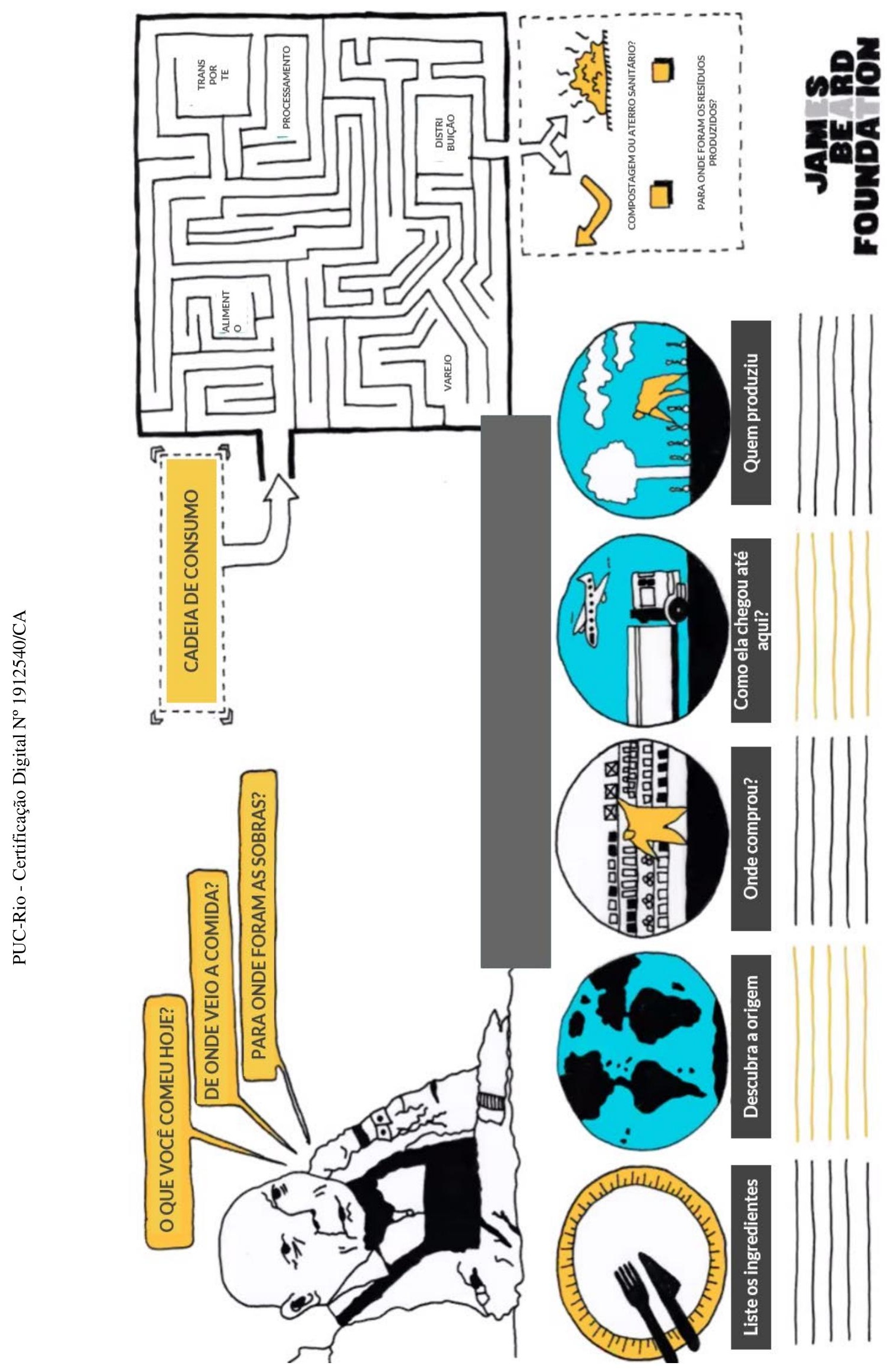

Figura 29. Diário do prato (Raphael Flaksberg, JBF). 


\subsection{Análise e Síntese}

Após compilar e analisar as informações coletadas nas entrevistas, os dados foram colocados em Cartões de Insight e uma primeira análise e síntese realizada. De acordo com o manual da MJV (Vianna et el., 2012), os Cartões de Insight possibilitam organizar os dados levantados na pesquisa exploratória, e reaparecem sempre que necessário quando surgem informações relevantes a serem acrescentadas (Anexo 06 . Cartões de Insight).

As informações coletadas sobre os produtores e chefs por meio dos questionários e entrevistas foram sintetizadas e agrupadas, então enviadas aos participantes 3 dias antes do primeiro webinário (agosto, 2020). O objetivo era sintonizar todos os participantes no pensamento geral, para iniciar as discussões a partir desse contexto. Durante o primeiro encontro, os participantes foram apresentados, e os tópicos previamente indexados foram debatidos:

- Características pessoais dos entrevistados;

- Características profissionais: formação, consciência e envolvimento com as questões de sustentabilidade; contemplando também as práticas cotidianas;

- Poder de decisão e liberdade do chef enquanto sócio ou empregado;

- Conhecimento e acesso à diferentes métodos de cultivo e variedades biológicas;

- Dificuldades de inserção e manutenção no mercado;

- Dificuldades relacionais, financeiras e práticas para trabalhar com pequenos produtores ou com restaurantes;

- Questões relacionadas à comunicação dos valores e práticas adotados pelo chef e pelo produtor;

- Funções do chef como um comunicador e educador do paladar;

- Relações de troca entre chefs e produtores, nos âmbitos culturais e econômico;

- Oportunidades e obstáculos gerais.

Além de provocar a discussão dos tópicos mais citados na fase de entrevista, outros pontos relevantes suscitados foram registrados. Após nova análise, as respostas similares foram agrupadas, e as questões mais relevantes no processo, do ponto de vista dos produtores, foram:

- Produção e venda: as incertezas de plantar sem garantia de escoamento da produção, que vão das culturas básicas às possibilidades de se investir em cultivos menos tradicionais. Não é possível concorrer diretamente no preço dos grandes atacadistas. 
- Escoamento: as demandas inconstantes e/ou em pequeno volume podem inviabilizar as entregas;

- A venda direta oferece oportunidade de melhorar a relação custo-benefício, mas precisa ser mais bem estruturada, uma vez que fazer todo o trabalho de venda e entrega exige que o produtor se ausente de sua produção;

- Trabalhar conjuntamente com chefs e entre produtores resolveria muitos dos obstáculos apresentados;

- Há pouca visibilidade para o trabalho no campo e espaço de mídia. Exceto para os produtores que participam de feiras livres, há remotas oportunidades de relacionamento direto com o consumidor final.

Do mesmo modo, as respostas dos chefs foram assim resumidas:

- Compras: dificuldades ou questões relativas à entrega dos insumos, tanto na quantidade quanto na variedade. Em algumas situações é preciso ter uma multiplicidade de fornecedores para que a demanda do restaurante seja atendida (segundo os mesmos critérios de entrega/qualidade/ quantidade);

- Cardápio: quando parte da disponibilidade de insumo, da sazonalidade, do que o produtor oferece, existe a demanda de uma elaboração frequente de novos pratos e preparos, que pode ser um exercício exaustivo, e muitas vezes não há a possibilidade de se realizarem testes. Outro ponto é a questão técnica de elaboração de fichas técnicas e controle de custos, quando o cardápio oscila com tanta frequência. A escala do empreendimento também tem grande peso nesse modelo de cardápio;

- Consciência: quando se toma consciência que esse modelo de negócio impacta diretamente na cadeia, nas esferas econômica, cultural e social, é possível atribuir ao chef o papel pedagógico, do acesso, transparência dos processos, preparo e consumo; além de poder conectar diretamente produtor e consumidor final. Sem fetiche. O estabelecimento pode também desenvolver uma estratégia de valorização da opção adotada, e atrair clientes.

Para a segunda webconferência (setembro, 2020), o mesmo procedimento inicial foi seguido, e a síntese novamente enviada aos participantes com três dias de antecedência. Com os dados do primeiro encontro compilados, o segundo debate se iniciou com a exposição das conclusões e questões do primeiro webinário, para validar, dar sequência e relevância às demandas ainda sem solução. Esse trâmite contribui para que, na eventualidade de um ou mais integrantes não estarem 
presentes em todas as reuniões, poderem acompanhar o desenvolvimento, e contribuir em uma próxima oportunidade.

No segundo encontro ficou clara a necessidade compartilhada pelos entrevistados de se estabelecer uma rede de chefs e produtores, com uma relação horizontal de troca. As discussões da dinâmica incentivaram alguns dos participantes a retomarem um coletivo de chefs do qual já faziam parte, em um movimento paralelo intitulado de "Reset". O grupo, chamado "Ecochefs" (Instituto Maniva) existe desde 2007, e se pauta na motivação da transformação socioambiental na cadeia alimentar a partir do apoio e da promoção dos pequenos agricultores. A retomada das atividades do grupo se deu ainda em setembro de 2020, objetivando ampliar sua atuação para o cenário nacional.

O terceiro e último encontro on-line foi pautado pela importância da rede de relacionamentos entre chefs, produtores e consumidores, a volta dos Ecochefs, e pelo entendimento da necessidade de se sugerir um conjunto de valores a serem observados pelo grupo, algo como o proposto pela comunidade da Junta Local no Anexo 07. Essa carta de valores é amparada em princípios de rede, sustentabilidade, rastreabilidade, localidade, transparência e respeito pelo tempo, processos e atores envolvidos.

Os entrevistados sugerem que essa rede deva ser firmada sobre princípios e práticas, com bases teóricas reconhecidas (ODS da ONU, EAT-Lancet e Guia Alimentar para a População Brasileira ${ }^{48}$ ). O quadro a seguir foi desenhado fundamentado nas discussões do último encontro sobre tais nortes.

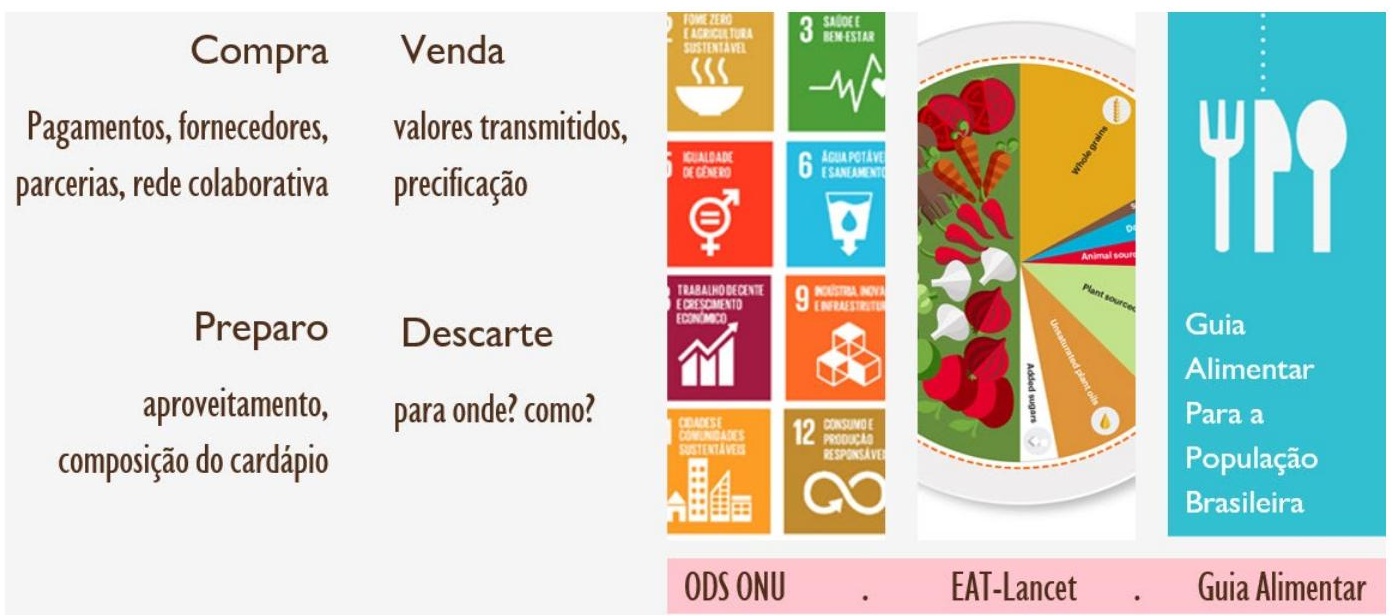

Figura 30 . Síntese de princípios e práticas.

${ }^{48}$ Willet, 2019; Ministério da Saúde, 2014. 
De posse das informações coletadas ao longo das entrevistas e discussões, seis perfis de atores foram traçados, utilizando-se as características mais marcantes dos participantes, resultando na construção das Personas. Essa ferramenta ajudou a consolidar o quadro da pesquisa e o entendimento dos tipos de usuários, para que sejam mais bem atendidos em suas demandas. Elas representam as "motivações, desejos, expectativas e necessidades, reunindo características de um grupo mais abrangente" (Vianna et al., 2012, p.80). As Personas auxiliam o desenhar do serviço, podendo ser consultadas em diversas etapas do processo criativo, sendo particularmente úteis na geração e na validação de ideias.

\begin{tabular}{|c|c|}
\hline \multicolumn{2}{|c|}{ MICHEL } \\
\hline NOME & \\
\hline 56 anos & \\
\hline Rio de Janeiro & \\
\hline FAMÍLIA casado, dois filhos & produtor \\
\hline \multirow{2}{*}{$\begin{array}{l}\text { VIDA Pequeno produtor orgânico na } \\
\text { região do Rio de Janeiro, Michel } \\
\text { trabalhou no campo desde jovem, e } \\
\text { recentemente passou a fazer parte de } \\
\text { CSA direcionado para restaurantes. } \\
\text { Dedica-se a testar novas espécies, } \\
\text { aumentando a biodiversidade local e } \\
\text { ampliado seu leque de opções para os } \\
\text { clientes }\end{array}$} & \\
\hline & $\begin{array}{l}\text { ASPIRAÇÕES Michel gostaria de ajudar } \\
\text { os agricultores de sua comunidade a fixar } \\
\text { suas familias no campo, e construir uma } \\
\text { rede de agricultura orgânica na região, } \\
\text { com suporte técnico e divulgação }\end{array}$ \\
\hline $\begin{array}{l}\text { AÇÕES Já está articulado com } \\
\text { outros produtores da sua região, } \\
\text { trocam mudas, dicas e compartilham } \\
\text { o aprendizado. } \\
\text { Ainda tem pouco contato com os } \\
\text { cozinheiros }\end{array}$ & $\begin{array}{l}\text { SENTE Ainda há muita fragilidade no } \\
\text { sistema de CSA, e nem sempre os produtores } \\
\text { conseguem escoar toda sua produção para a } \\
\text { cidade. Transporte e garantia de venda são as } \\
\text { maiores barreiras a serem transpostas }\end{array}$ \\
\hline $\begin{array}{l}\text { ESPERA Um relacionamento mais } \\
\text { próximo com os chefs de cozinha, } \\
\text { para construir juntos um repertório } \\
\text { de produtos }\end{array}$ & $\begin{array}{l}\text { ACREDITA Compartilhamento do } \\
\text { conhecimento e união dos produtores pode } \\
\text { fortalecer a agricultura da região. Quando os } \\
\text { pequenos produtores se unem, todos se } \\
\text { beneficiam, não há necessidade de } \\
\text { competição. }\end{array}$ \\
\hline
\end{tabular}




\begin{tabular}{|c|c|}
\hline NOME & \\
\hline 35 anos & \\
\hline Teresópolis & \\
\hline FAMÍLIA casada, dois filhos & \\
\hline \multirow{2}{*}{$\begin{array}{l}\text { VIDA Sua família produz queijo de } \\
\text { maneira artesanal há três gerações. } \\
\text { Embora tenha ido estudar na cidade, } \\
\text { Lúcia voltou para a região rural, } \\
\text { trazendo conhecimento e melhorias } \\
\text { técnicas e sanitárias para sua } \\
\text { comunidade, sem perder as tradições. } \\
\text { Fabrica seus prórpios queijos desde } \\
\text { então }\end{array}$} & \\
\hline & $\begin{array}{l}\text { ASPIRAÇÕES Ajudar sua comunidade } \\
\text { com conhecimento, enaltecendo a } \\
\text { importância das práticas regionais, } \\
\text { adaptando à modernidade. Estabelecer } \\
\text { um regime de venda garantido }\end{array}$ \\
\hline $\begin{array}{l}\text { AÇÕES Tem uma produção limitada } \\
\text { de queijo, com manteiga como } \\
\text { subproduto. Respeita os ciclos de } \\
\text { vida das vacas, deixando sempre a } \\
\text { primeira ordenha do dia para os } \\
\text { bezerros }\end{array}$ & $\begin{array}{l}\text { SENTE A produção em pequena escala é } \\
\text { frágil e desassistida. Não há incentivos, muitas } \\
\text { vezes é difícil escoar o produto }\end{array}$ \\
\hline $\begin{array}{l}\text { ESPERA Que a legislação de adeque à } \\
\text { realidade do pequeno produtor, e não } \\
\text { o contrário. Há muita qualidade nos } \\
\text { métodos ancestrais que a indústria não } \\
\text { consegue replicar e as leis não estão } \\
\text { adequadas para isso }\end{array}$ & $\begin{array}{l}\text { ACREDITA Os restaurantes podem dar } \\
\text { voz e visibilidade para os produtores rurais. } \\
\text { Com o poder de mídia, muitas questões } \\
\text { como os selos e barreiras sanitárias já foram } \\
\text { abordados, e a situação tende a melhorar. } \\
\text { Quanto mais expostos, mais pessoas } \\
\text { aprendem sobre seus produtos }\end{array}$ \\
\hline \multicolumn{2}{|c|}{ DANIEL } \\
\hline NOME Daniel & \\
\hline IDADE 36 anos & \\
\hline ONDE Rio de Janeiro & \\
\hline FAMÍLIA casado, uma filha & chef \\
\hline \multirow{2}{*}{$\begin{array}{l}\text { VIDA Chef da cozinha e sócio do } \\
\text { restaurante, Daniel divide seu tempo } \\
\text { com a criação de pratos, de sua filha e } \\
\text { de um futuro melhor através da } \\
\text { comida. Passa cerca de } 8 \text { h diárias na } \\
\text { cozinha, e investe seu tempo livre em } \\
\text { conhecer cada vez mais os produtos e } \\
\text { diferentes técnicas de preparo dos } \\
\text { alimentos. }\end{array}$} & \\
\hline & $\begin{array}{l}\text { ASPIRAÇÕES Fazer uma cozinha de } \\
\text { excelência, com um bom trabalho de equipe, } \\
\text { respeitando o meio ambiente, produtos, } \\
\text { produtores, e tornando acessível a } \\
\text { gastronomia de qualidade, sem exageros. }\end{array}$ \\
\hline $\begin{array}{l}\text { AÇÕES Tem uma pequena rede de } \\
\text { contatos, mas depende ainda de } \\
\text { alguns fornecedores mainstream para } \\
\text { acomodar as necessidades da } \\
\text { produção e manter o equilíbrio } \\
\text { financeiro. }\end{array}$ & $\begin{array}{l}\text { SENTE A comunidade de cozinheiros e } \\
\text { produtores ainda é muito dispersa, seria muito } \\
\text { relevante participar de uma rede, de um } \\
\text { movimento que trouxesse para a mesma mesa } \\
\text { todos os participantes da cadeia. }\end{array}$ \\
\hline $\begin{array}{l}\text { ESPERA Facilitar seu dia a dia nas } \\
\text { compras, recebimento e ampliar a } \\
\text { rede de contatos }\end{array}$ & $\begin{array}{l}\text { ACREDITA Com uma rede sólida de } \\
\text { parcerias no campo e entre os cozinheiros } \\
\text { é possível facilitar o acesso de todos a bons } \\
\text { ingredientes, fomentar uma alimentação } \\
\text { mais saudável e equilibrada, com isso } \\
\text { aproximar ainda mais o consumidor final } \\
\text { dos valores construídos pelo Restaurante }\end{array}$ \\
\hline
\end{tabular}




\begin{tabular}{|c|c|}
\hline Maria Francisca & \\
\hline 38 anos & \\
\hline Belo Horizonte & \\
\hline FAMÍLIA casada & chef \\
\hline \multirow{2}{*}{$\begin{array}{l}\text { VIDA Chef da cozinha e sócia do } \\
\text { restaurante, Maria acredita que é } \\
\text { possível fazer comida boa, limpa e } \\
\text { justa. Há } 10 \text { anos trocou os } \\
\text { fornecedores, comprou um pequeno } \\
\text { sítio próximo à cidade, e decidiu } \\
\text { plantar seus próprios ingredientes. } \\
\text { Durante a quarentena, fazia cestas de } \\
\text { produtos para vender online, } \\
\text { viabilizando financeiramente o sítio }\end{array}$} & \\
\hline & $\begin{array}{l}\text { ASPIRAÇÕES Fazer uma cozinha de } \\
\text { excelência, com um bom trabalho de equipe, } \\
\text { respeitando o meio ambiente, produtos, } \\
\text { produtores, e tornando a gastronomia de } \\
\text { qualidade cada vez mais acessível }\end{array}$ \\
\hline $\begin{array}{l}\text { AÇÕES Planta e cria a maior parte de } \\
\text { seus insumos, complementando com } \\
\text { insumos de pequenos produtores } \\
\text { parceiros. Completa o ciclo de vida } \\
\text { retornando para o sítio o pouco que } \\
\text { sobra. Faz compostagem e reuso }\end{array}$ & $\begin{array}{l}\text { SENTE A falta de informação e o } \\
\text { desinteresse ou comodismo ainda são os } \\
\text { maiores obstáculos. Dá trabalho romper o } \\
\text { paradigmas, mas é papel dos cozinheiros mudar } \\
\text { o status atual }\end{array}$ \\
\hline $\begin{array}{l}\text { ESPERA Trabalhando ativamente } \\
\text { nas redes sociais, Maria espera que } \\
\text { a visibilidade do que acontece em } \\
\text { seu restaurante motive outros } \\
\text { profissionais a fazer o mesmo }\end{array}$ & $\begin{array}{l}\text { ACREDITA É possível construir um novo } \\
\text { modelo de restauração em que produtores, } \\
\text { cozinheiros e consumidores andem juntos, } \\
\text { se beneficiem mutuamente. Trocar custos } \\
\text { por valores é apenas o primeiro passo }\end{array}$ \\
\hline NOME & \\
\hline IDADE 55 anos & \\
\hline ONDE Rio de Janeiro & \\
\hline FAMÍLIA casada, uma filha & consumidor \\
\hline \multirow{2}{*}{$\begin{array}{l}\text { VIDA Profissional liberal, Alice } \\
\text { passou a rever sua relação com a } \\
\text { comida após enfrentar uma doença } \\
\text { grave. } \\
\text { Mesmo que nem sempre possa } \\
\text { comprar de pequenos produtores por } \\
\text { questões de custo, tenta ao máximo } \\
\text { fazer suas compras em feiras livres, } \\
\text { estabelecendo um relacionamento } \\
\text { com o produtor }\end{array}$} & \\
\hline & $\begin{array}{l}\text { ASPIRAÇÕES Ampliar cada vez mais seu } \\
\text { acesso a produtos de origem conhecida, se } \\
\text { informar sobre produtos, sazonalidade, e } \\
\text { está disposta a diminuir o consumo de } \\
\text { derivados animais, que encarecem o } \\
\text { orçamento }\end{array}$ \\
\hline $\begin{array}{l}\text { AÇÕES Prioriza suas compras de } \\
\text { hortifruti na feira, sempre que } \\
\text { possível na feira orgânica. } \\
\text { Faz também compras online de } \\
\text { plataformas alternativas. }\end{array}$ & $\begin{array}{l}\text { SENTE Ainda que algumas vezes seja mais } \\
\text { caro comprar na feira, de modo geral não } \\
\text { aumentou seus gastos com alimentação, mas } \\
\text { sente que a comida é muito melhor, mais } \\
\text { fresca e saborosa }\end{array}$ \\
\hline $\begin{array}{l}\text { ESPERA Com essa mudança de } \\
\text { hábitos, quer aprender a cozinhar } \\
\text { outros ingredientes, aumentar o } \\
\text { repertório de receitas e técnicas. }\end{array}$ & $\begin{array}{l}\text { ACREDITA Se a produção de } \\
\text { agroflorestais/orgânicos tiver incentivos, vai } \\
\text { se tornar cada vez mais acessível. } \\
\text { Há muito mais informações e dicas hoje em } \\
\text { dia, isso contribui muito. } \\
\text { As compras online vieram para ficar }\end{array}$ \\
\hline
\end{tabular}




\begin{tabular}{|c|c|}
\hline NOME João & \\
\hline 36 anos & \\
\hline ONDE Rio de Janeiro & \\
\hline FAMÍLIA solteiro, uma filha & consumidnr \\
\hline \multirow{2}{*}{$\begin{array}{l}\text { VIDA Mudar a dieta para } \\
\text { vegetarianismo/veganismo foi um } \\
\text { movimento radical, que perdura. } \\
\text { Ainda não é financeiramente viável } \\
\text { comprar tudo de pequenos } \\
\text { produtores, mas com as redes de } \\
\text { compra online/redes sociais as coisas } \\
\text { estão mais fáceis. Frequentar a feira é } \\
\text { outra solução acessível. }\end{array}$} & \\
\hline & $\begin{array}{l}\text { ASPIRAÇÕES Saber cada vez mais sobre o } \\
\text { que como, como preparar, que outras coisas } \\
\text { posso comer para ampliar meu repertório } \\
\text { de sabores e nutrientes }\end{array}$ \\
\hline $\begin{array}{l}\text { AÇÕES Está trocando aos poucos as } \\
\text { compras convencionais, aprendendo } \\
\text { novas receitas, plantando temperos e } \\
\text { pequenas hortaliças em casa. } \\
\text { Aprendendo a comer itens que eram } \\
\text { desconhecidos }\end{array}$ & $\begin{array}{l}\text { SENTE Poderia estar mais próximo e saber } \\
\text { mais sobre quem produz sua comida, mas } \\
\text { entende que isso já melhorou muito com as } \\
\text { compras diretas, em que há troca entre os } \\
\text { produtores e consumidores }\end{array}$ \\
\hline $\begin{array}{l}\text { ESPERA Que haja um aumento } \\
\text { de oferta em quantidade, qualidade } \\
\text { e preço de comidas vegetarianas a } \\
\text { veganas, e que o preço se torne } \\
\text { mais atrativo }\end{array}$ & $\begin{array}{l}\text { ACREDITA É possível construir um novo } \\
\text { modelo de restauração em que produtores, } \\
\text { cozinheiros e consumidores andem juntos, } \\
\text { se beneficiem mutuamente. Trocar custos } \\
\text { por valores é apenas o primeiro passo }\end{array}$ \\
\hline
\end{tabular}

Figura 31 . Personas

A sessão de discussão com os consumidores, póstera à resposta dos questionários, apontou algumas características de relevância para as considerações sobre o perfil e construção macro do cenário a ser explorado, que reforçou o perfil anteriormente sintetizado na construção das Personas:

maioria dos entrevistados estaria disposto a pagar mais por alimentos mais saudáveis e sustentáveis, contanto que o valor fosse viável dentro do orçamento. majoritariamente acima de 40 anos

majoritariamente classes $A, A B$ e $B$

majoritariamente feminino, com curso superior consumidores acostumados a ter todos os produtos o ano todo
Interesse de saber sobre os benefícios de se consumir produtos orgânicos, porém não pesquisam por falta de tempo

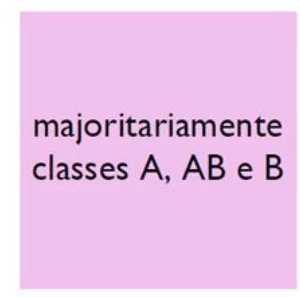

São influenciados pelas mídias sociais e por programas que falem sobre alimentação

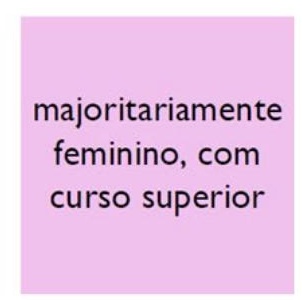

relações custobenefício são determinantes

Figura 30 . Dados mais relevantes sobre os consumidores entrevistados

Para o grupo dos consumidores entrevistados, seguindo novamente a metodologia DELPHI, as respostas foram compartilhadas e os resultados discutidos 
de forma coletiva em uma sessão on-line. Com isso, foi possível inferir que as informações coletadas dos entrevistados indicam uma mudança no padrão de consumo durante o ano de 2020, claramente influenciada pelo isolamento social imposto pelo COVID-19. Enquanto para alguns indivíduos cozinhar em casa e procurar saber mais sobre os alimentos já era uma prática ou uma tendência, para outros, passou a ser uma necessidade, face ao controle de gastos e disponibilidade, como mostra a Figura 31 . Perfil dos consumidores entrevistados.

A planilha anexa (Anexo 05 . Rotina dos entrevistados) mostra como o aproveitamento, a relação afetiva e a praticidade influenciaram as escolhas. Outra conclusão que se pôde inferir do estudo foi a relativa sensação de dispor de mais tempo para alguns preparos longos (como fermentados em geral), influenciada por programas culinários e troca com amigos e familiares.

$\begin{array}{lll}\text { Gênero } & \text { Motivações } & \\ \text { if } 82 \% & \text { - Novos utensilios e } & \text { - Comodidade ou preguiça } \\ \text { in } 18 \% & \text { equipamentos } & \text { - Cozinhar receitas } \\ & \text { - Postagens, programas } & \text { inéditas ou que exigem } \\ & \text { de TV } & \text { tempo } \\ & \text { - Amigas cozinhando } & \text { - Poder retomar ou mudar } \\ & \text { coisas similares } & \text { bons hábitos }\end{array}$

O que determinou o cardápio

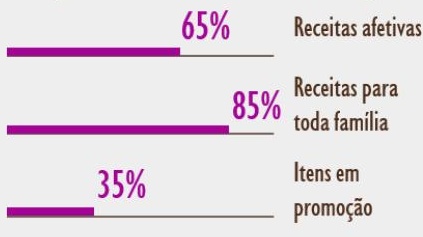

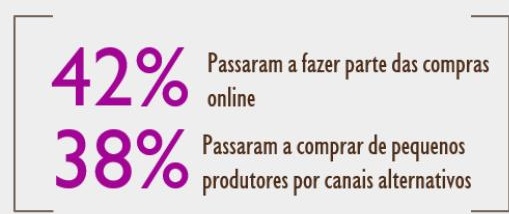

Maiores desafios

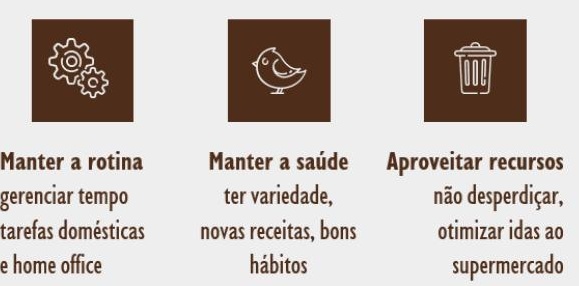

Figura 32 . Perfil de consumidores entrevistados

Os hábitos alimentares brasileiros foram recentemente sumarizados em um estudo realizado por Walter Belik (O Joio e o Trigo, 2020) apontando os principais obstáculos a serem debatidos para superar as fraquezas e desigualdades do sistema alimentar no Brasil. Dentre os dados apontados, destaca-se a monotonia da dieta do brasileiro médio, com 45\% das refeições baseadas em 10 itens: arroz, feijão, pão francês, carnes bovina e de frango, açúcar, banana, leite, refrigerantes e cerveja. A pesquisa mostra como a padronização da refeição brasileira atinge igualmente a população urbana e rural, se sobrepondo à diversidade e variedade de alimentos e às regionalidades, contrariando as orientações do Guia Alimentar para a População Brasileira (Ministério da Saúde, 2014). Os resultados desse estudo reforçam a falta de diversidade alimentar apresentada pelos entrevistados nesta dissertação.

Os dados colhidos nessa etapa coincidem também com os apontados em diversas pesquisas realizadas por outras instituições nacionais e internacionais acerca 
da mudança de hábitos de consumo, particularmente conectadas à pandemia do COVID-19. Elas apontam um grande aumento dos serviços de venda on-line, e confirmam uma mudança de hábitos tanto nas compras quanto no consumo durante o primeiro semestre de 2020, no que diz respeito a saudabilidade, controle de desperdício, sustentabilidade e eficiência (Produce Marketing Association, 2020; Criteo, 2020; Steele et al., 2020, SEBRAE, 2020). A crescente demanda por compras através de e-commerce foi apontada em todas as pesquisas com números significativos, oscilando de $80 \%$ a 200\% em gêneros alimentícios, chegando a quase triplicar em relação ao mesmo período de 2016 (Qualibest, 2020; Criteo, 2020; SEBRAE, 2020, NUPENS USP, 2020).

A análise das informações é coincidente, também, com o apontado pela pesquisa on-line realizada pela Junta Local (2020) como mostra o quadro a seguir:

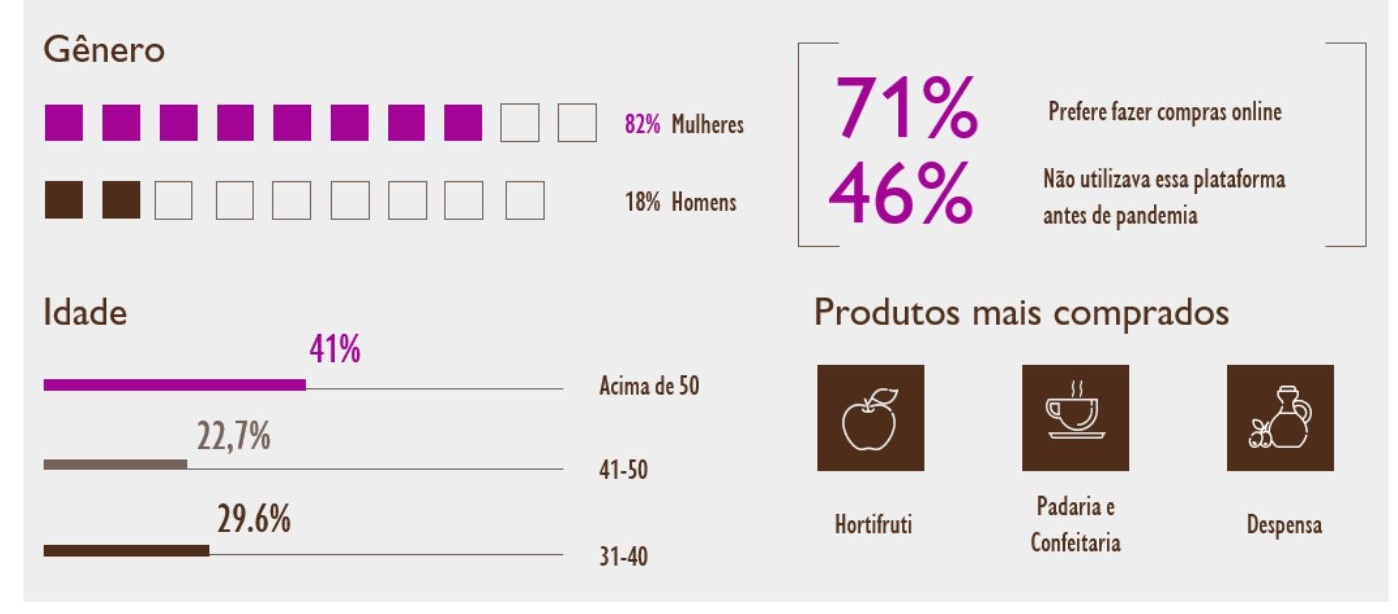

Figura 33 . Perfil de consumidores comerciais (Junta Local, 2020)

Após a finalização dos encontros, as alíneas foram arranjadas em três categorias: dificuldades, desejos e oportunidades; a fim de, a partir dessa reflexão, serem apontados os desafios projetuais. Um quadro síntese das respostas por produtor, chef e empreendedor, pode ser vista em detalhe no Anexo 08 (Sessões Generativas. painel de especialistas). Nessa etapa de síntese e avaliação, as entrevistas e grupos de foco possibilitaram compreender, discutir, apontar situações e as questões mais pertinentes à cadeia.

Do ponto de vista dos produtores, os desafios mais urgentes identificados trouxeram à tona:

- a necessidade de fomentar a construção de um sistema de trocas mais justo, saudável, sustentável e resiliente;

- a relevância de estreitar o relacionamento entre todos os atores da cadeia, melhorar a comunicação e estimular a troca de saberes; 
- a importância de garantir o escoamento da produção e excedente das colheitas e xepas das feiras;

- a urgência em compatibilizar sustentabilidade local, interesse dos consumidores e viabilidade econômica;

- a fixação do produtor no campo;

- a valorização do trabalho rural, seus produtos e manutenção da biodiversidade.

Para os chefs, os desafios e benefícios dessa relação tocam as seguintes esferas:

- a necessidade de uma rede de produtores e chefs, que se conheçam e a seus produtos, e quanto mais pessoas na rede, maiores os ganhos para todos;

- a viabilidade econômica desse modelo, tanto na compra dos insumos quanto na venda de seus produtos finais;

- uma maneira prática de realizar compras de múltiplos produtores de maneira centralizada, com entrega consistente, padronizada;

- a fundamental importância da comunicação, para transmitir os valores adotados ao consumidor, para promover a troca de saberes e interação com produtores e consumidores.

Quanto aos consumidores, as questões mais recorrentes disseram respeito a:

- interesse em lojas físicas ou virtuais que publicizem a origem dos alimentos, quanto ao produtor e ao produto;

- política de transparência nos preços praticados;

- acesso à informação sobre ingredientes desconhecidos e/ou modo de preparo dos mesmos. 


\section{DIFICULDADES}
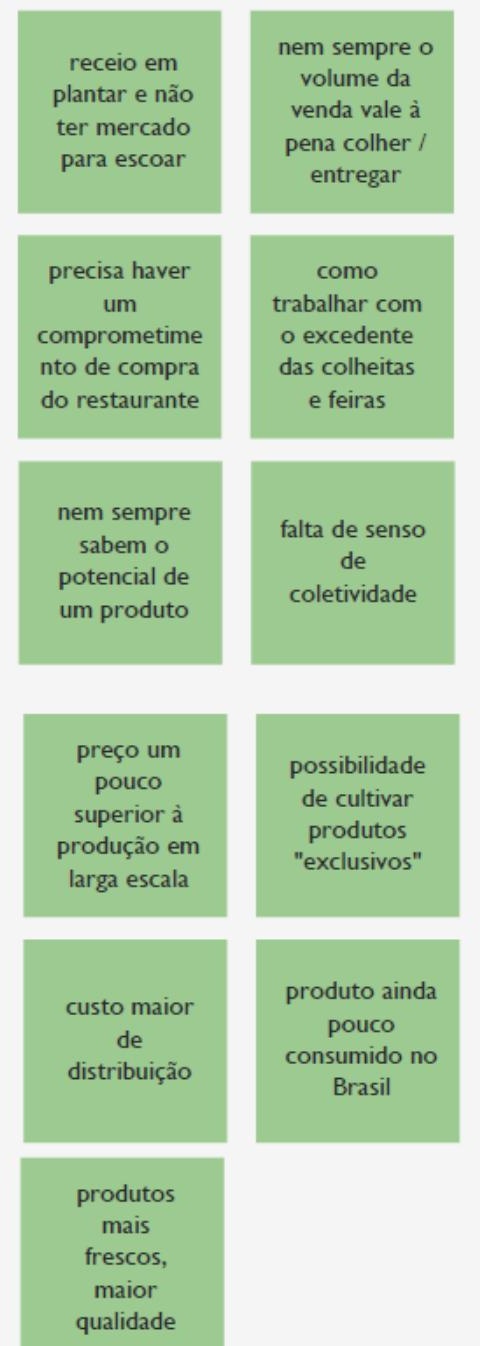

DESEJOS

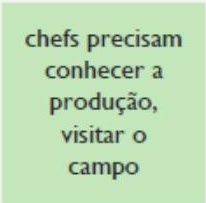

\begin{tabular}{|c|c|}
\hline para haver o & agricultores \\
consumo & podem ir nos \\
consciente o & restaurantes ver \\
consumidor & como seus \\
\hline precisa conhecer & produtos são \\
\hline o produtor & trabalhados \\
\hline
\end{tabular}

redes de comercialização

e gerenciamento (diluir custos de logística, gestão) troca de expertise, capacitação e poder de barganha)

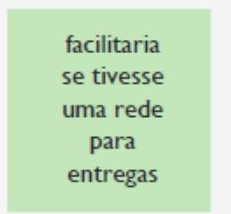

\begin{tabular}{|c|}
\hline chefs de \\
cozinha tem \\
papel \\
fundamental \\
na promoção \\
do produto \\
\hline
\end{tabular}

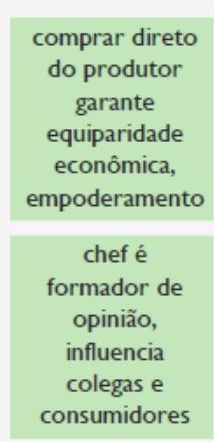

OPORTUNIDADES
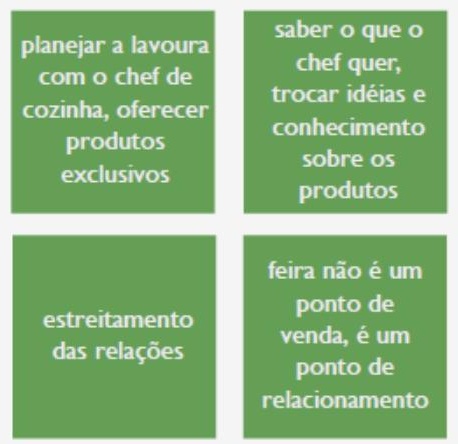

morar no

campo não é

viver isolado e

sim em

comunidades

colaborativas
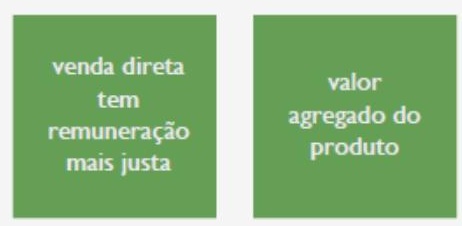

impacto

econômico e

socioambiental

na localidade,

protagonismo

de quem planta

compromisso

real com a

sustentabilidade

não estratégia

de marketing

Figura 34 . Análise e Síntese Produtores 
DIFICULDADES
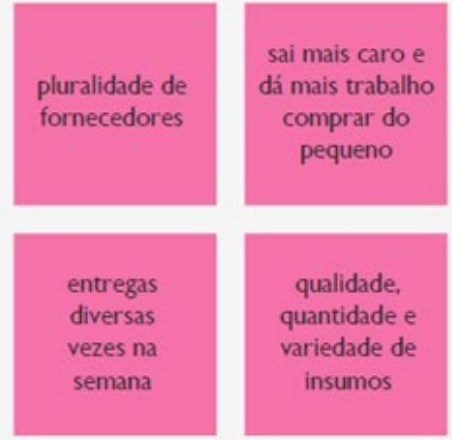

como é dificil

engajar os chefs

nas discussões

fora da cozinha

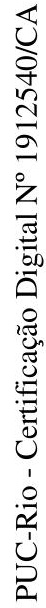

\section{DIFICULDADES}
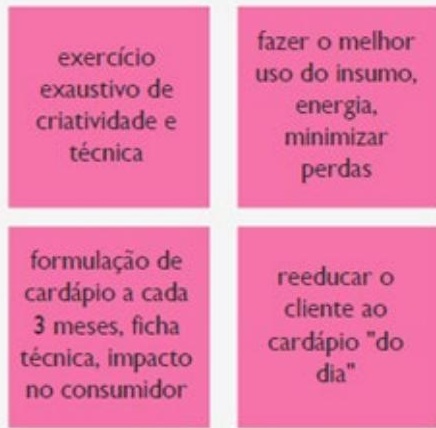

fugir dos padrōes de gosto já estabelecidos I esperados

\section{DESEJOS}

como construir
esse
relacionamento
entre produtor
e chef?

produtos

exclusivos e de

qualidade

Uma maneira

mais fácil de ter

acesso a novos

produtores e

produtos
OPORTUNIDADES
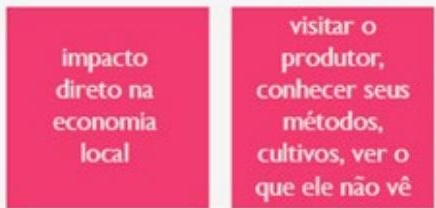

Conhecer de perto
o produtor
possibilita
diversidade de
produtos para
ompor o cardápio

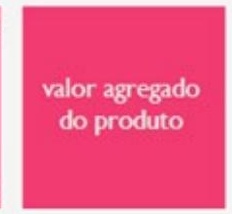

Entender o produtor: melhor

formade

comunicar o

processo para o

consumidor final

feira não é um

ponto de venda,

é um ponto de

relacionamento

entender que não pode ser um processo solitário, precisa de uma rede

estabelecer rede de produtores, compartilhar com colegas e clientes
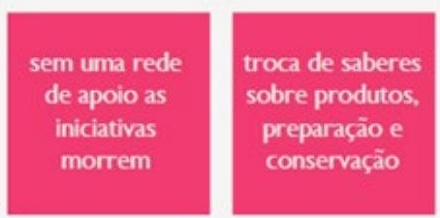

poder ter

produtos novos

ou

desconhecidos

estreitamento

das relaçōes

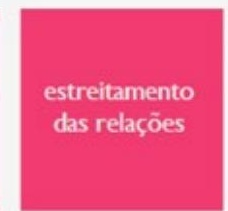

\section{OPORTUNIDADES}

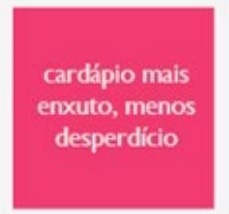

explorar as

melhorar o

aproveitame

nto dos

produtos

menus

flexiveis

criar o

cardápio à

partir dos

produtos

banco de

dados de

receitas

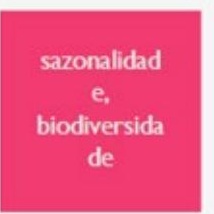

troca de
saberes
sobre
produtos,
preparação e
conservação

coragem do
chef de
romper os
padrões de
cardápio e
serviço

mudar as

expectativas das

pessoas quanto

ao cardápio.

mostrar que

local é melhor

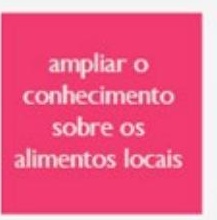

construir a

identidade do

estabelecimento

leva clientes que

se identificam, e

outros junto à ele 
DIFICULDADES

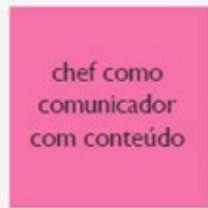

Nem todo cozinheiro tem a

palavra final na

escollha de quais

insumos comprar

\section{DESEJOS}
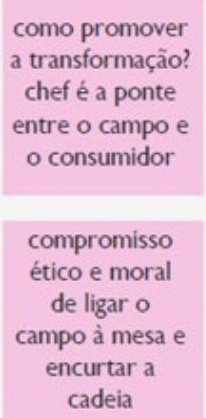

cadeia

compras
coletivas
dependem da
agilidade e
presteza de um
lider

lider

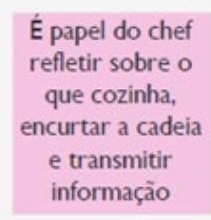

papel do chef refletir sobre o que cozinha,

e transmitir informação

\section{OPORTUNIDADES}
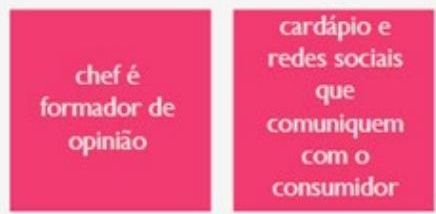

trabalhar as

midias para

disponibiliza

ro cardápio

diário

dar destaque

ao produtol

produtor

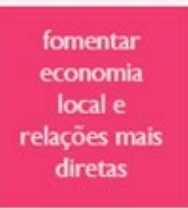

Figura 35 . Análise e Síntese Chefs

\section{DIFICULDADES}

\begin{tabular}{l|c} 
falta divulgação & medo ou \\
de alimentos & desconhecimento \\
usados pelos & de ingredientes \\
restaurantes & ou técnicas de \\
mostrando a & preparo \\
procedência &
\end{tabular}

Produtos

orgânicos e

artesanais

tendem a ser

mais caros

\section{DESEJOS}

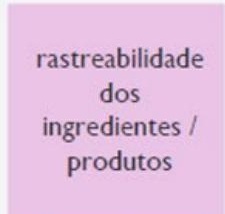

relação de duas vias onde o consumidor entra em contato com a história do alimento e o produtor divulga seu produto, criam uma relação direta

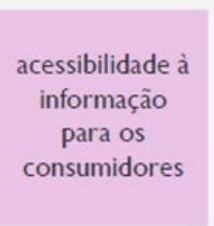

dar ao consumidor a proximidade com o produtor, dele saber quem produz o que ele come: qual o nome, qual a história..

\section{OPORTUNIDADES}

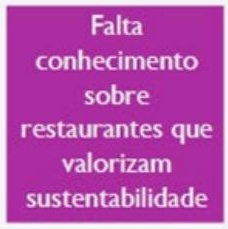

interesse ou

contato com

alimentos de

peq. produtores,

orgânicos,

agroecológicos falta informação

sobre a origem

dos alimentos $\mathrm{e}$

criação dos

animais
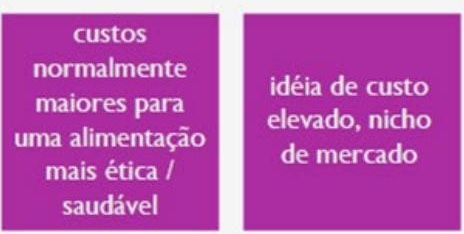

ao estabelecer uma

relação com quem produz sua comida, o consumidor

respeita e valoriza mais o trabalho e o produto

Figura 36 . Análise e Síntese Consumidores 


\subsection{Ideação}

Nas etapas precedentes foi possível compreender, discutir, apontar situações e levantar ideias para solucionar as questões mais recorrentes, sintetizando as ideias na fase exploratória. Sendo um processo iterativo por natureza, ocorre o que Zampollo (2014) chama de Rethink and Merge ${ }^{49}$, em que a nominação das etapas tem caráter didático, mas não acontecem de forma linear.

Concluídas as etapas de exploração remota e de campo, a presente investigação mostra como o Design pode contribuir para a compreensão da atualidade e para propor maneiras de superar as adversidades, construindo novas realidades no âmbito das CCCAs. A proposta foi calcada nos preceitos metodológicos, em um processo de participação e co-criação, com fusão e validação das ideias do painel de especialistas entrevistados com a experiência da autora, como cozinheira e pesquisadora.

Partindo de uma iniciativa bottom up, ou seja, de baixo para cima, o trabalho tem como epicentro as inquietações da pesquisadora no papel de chef de cozinha, apoiada por seus pares. Ele é complementado pelo movimento top down, ou de cima para baixo, do (Food) Design Thinking e de Serviços, com o olhar do designer no papel de especialista. O design colaborativo e participativo, nesse sistema, projeta as relações, o sentido, o serviço na esfera do "eu-tu" (Buber, 2002), para todos os atores da cadeia, podendo ser escalonado ou multiplicado, desde que mantidas as relações de pessoalidade.

Os desafios de projeto propostos pelos participantes foram agrupados de maneira sintética, com foco nas questões práticas do dia a dia da cozinha, reverberando nas extremidades da Cadeia. Assim chegou-se ao Desafio de Food Design: uma rede colaborativa que promova relações capazes de fomentar um sistema alimentar mais justo, saudável, sustentável e resiliente.

49 "Pequeno, local, aberto, entrelaçado". 

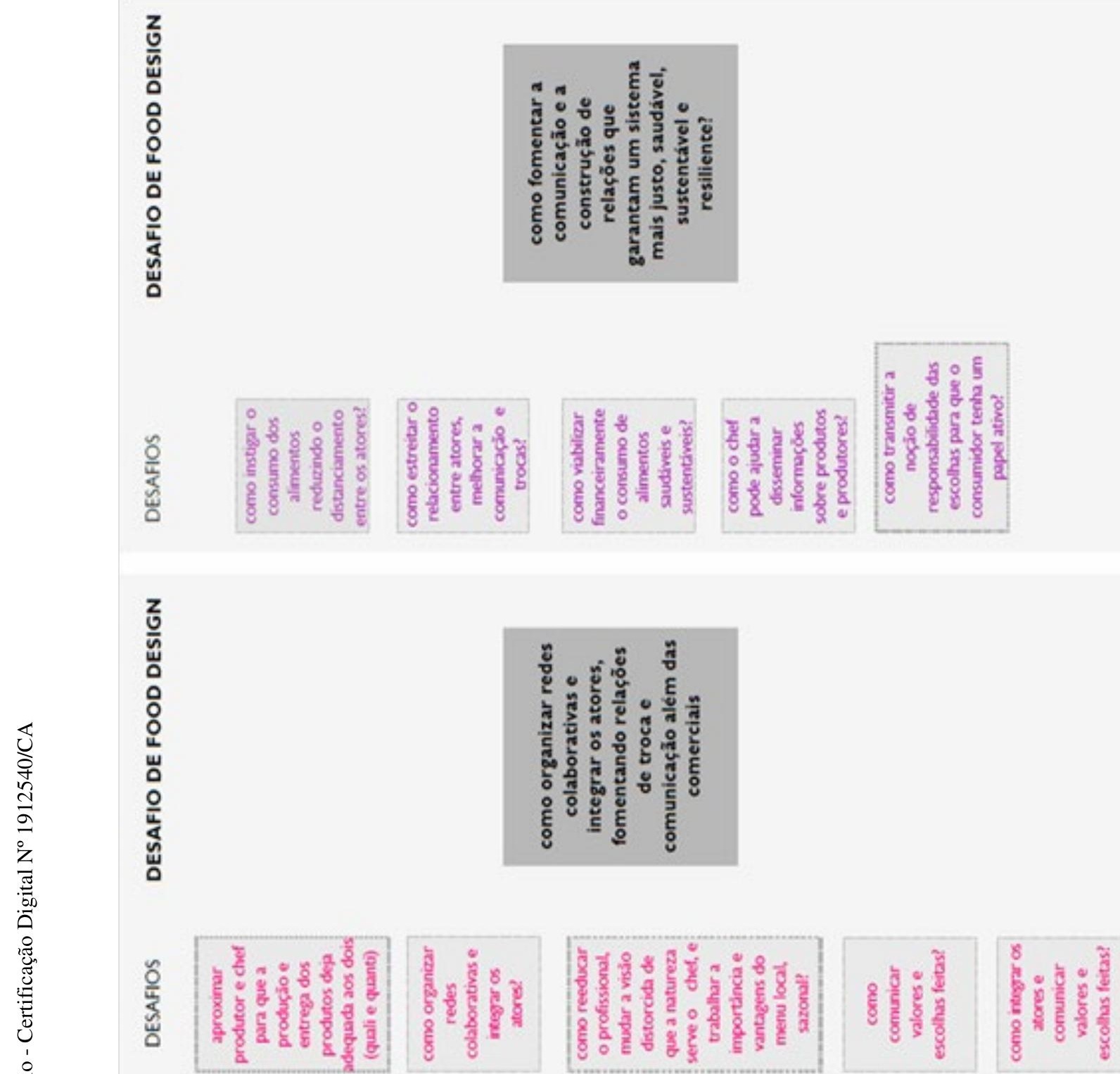

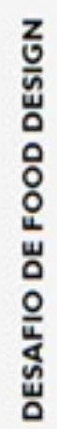
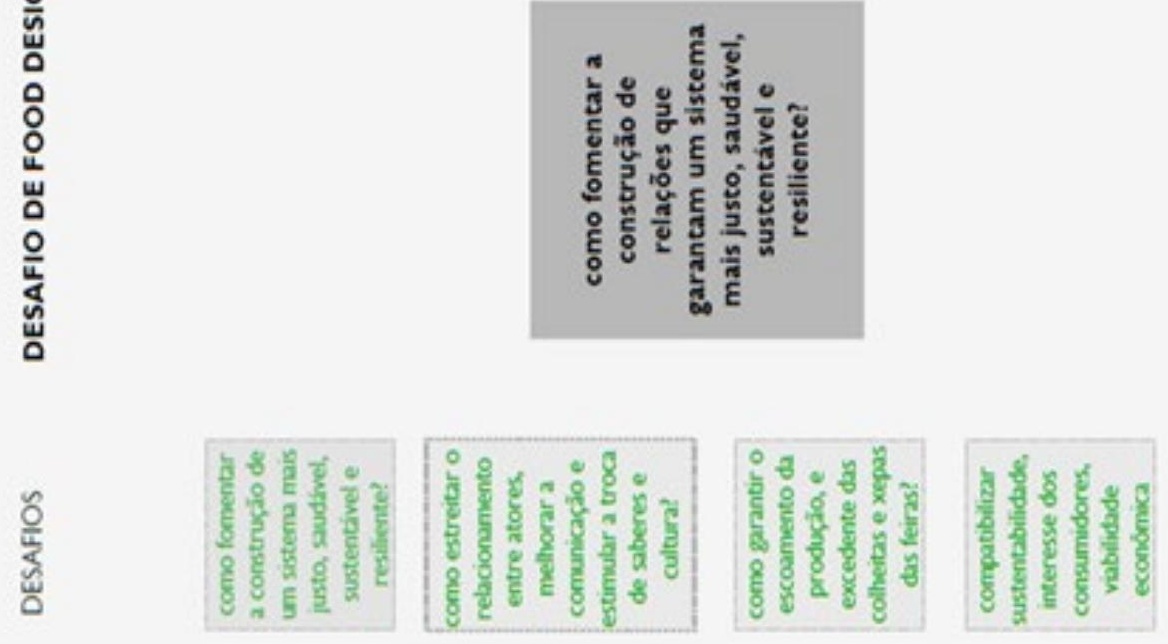

Figura 37 . Síntese do Desafio de Food Design 
O projeto proposto visa fomentar uma sólida malha de relacionamento, com práticas e princípios bem fundamentados, ancorada em reuniões sistemáticas, promovendo debates, compartilhamento de projetos e conhecimento, ao mesmo tempo em que se habilita um serviço de curadoria para produtores e chefs. Somados, os serviços formam o alicerce operacional da rede, culminando em uma malha de abastecimento. Os valores desse conjunto de princípios e práticas são transmitidos aos consumidores através das mídias digitais, feiras e restaurantes; de modo a potencializar as trocas mercantis e humanas entre todos os atores.

Assim nasce o Planta, um serviço baseado em um coletivo de chefs que, através de uma plataforma de compras e relacionamento que promove produtores e chefs, amplifica a visibilidade e maximiza o acesso de informações ao consumidor final. O serviço oferecido é composto por feiras, e-commerce, loja física e cardápio virtual, conectando os três atores elencados da cadeia de produção e consumo de alimentos de maneira direta.

As ideias foram concatenadas para viabilizar maneiras de se facilitar o escoamento da produção, desintermediando as relações e otimizando as compras/entregas. Isto permite ao chef de cozinha trabalhar com os ideais do consumo consciente de alimentos, disseminando esses valores e práticas ao consumidor final. Ao mesmo tempo, esse modelo de negócio funciona como uma vitrine para os pequenos produtores, e a ampliação do mercado consumidor favorece a continuidade e crescimento de seus negócios.

As aspirações relacionais dos atores, que acreditam em um modelo de troca mais equilibrado e recíproco, serão contempladas com os encontros mensais entre produtores e chefs, assim como nas feiras, na loja física e nos restaurantes, em que, além das trocas entre pares, há também a oportunidade de relacionamento com o consumidor final.

Foi realizado um levantamento de aplicativos e sites de compras, e, de modo geral, o público-alvo para esse tipo de mídia é o consumidor final. Nos raros casos em que se oferecem possibilidades para compra em varejo, com condições comerciais adequadas, é insuficiente a oferta de informações quanto a proveniência dos produtos, particularmente nos termos da ética abordados por esse trabalho. A curadoria oferecida pela rede de chefs do Planta é crucial para garantir produtos de qualidade superior, com mínimo impacto ambiental, e máximas oportunidades de relacionamentos.

A plataforma on-line proposta apresenta interfaces diferentes para cada um dos três tipos de usuários, unificando e ampliando canais relacionais existentes. 
Como uma ferramenta de compras, ela torna possível ao cliente (chef ou consumidor final) fazer pedidos à uma central única, e ter acesso a uma entrega mais regular e eficiente.

Para os pequenos produtores, essa ferramenta exime ou minimiza a necessidade de se dedicarem às tarefas de marketing e remessa. Essa ocupação geralmente significa se ausentar da lavoura/beneficiamento, ao menos parcialmente. Estar presente nas feiras, nos mercados, na entrega de seus produtos, requer articulação para estabelecer uma rede de contatos e coordenaç̧ão de operações para divulgação, coleta e distribuição.

Um grande diferencial trazido pelo Planta é contemplar a venda B2B (Business to Business ou venda entre empresas - em que o restaurante pode comprar insumos para seu consumo ou até mesmo oferecer revenda direta para o cliente final) e B2C (Business to Consumer ou venda para o consumidor final). No B2B, as condições de preço e pagamento são diferenciadas, dado o volume e regularidade, tributações e demais particularidades desse modelo; que não ocorrem para o consumidor final.

O serviço do Planta é alimentado por um banco de dados unificado, que provê com uma entrada informações distintas aos três tipos de usuários, potencializando assim o alcance da ferramenta. Para sintetizar visualmente os pontos de contato entre os atores e identificar as etapas mais problemáticas ou inspiradoras da cadeia foi utilizado o mapa de Jornada do Usuário (Figura 37، Jornada completa no Anexo 09). Com base nessa representação gráfica, foram criadas as planilhas de dados que alimentam a plataforma, além de validar o artefato proposto por meio de simulação gráfica (Figuras 38 a 40).

A partir da base de dados de produtores e chefs/ restaurantes, todos podem acessar um único site/aplicativo, que exibe tanto agricultores e artesãos com seus produtos quanto chefs e restaurantes parceiros. Tão importante quanto informações sobre os produtos à venda, geolocalização, disponibilidade, é a inserção de uma minibiografia dos atores, narrada com suporte imagético de fotos e pequenos vídeos. Os pedidos podem ser feitos de acordo com as necessidades, disponibilidade e capacidade de estoque dos participantes.

O compêndio de dados e storytelling dos produtores oferece aos chefs a informação de produtos, disponibilidade, valor e escala de entrega, assim como de quem produz o alimento, e em quais condições. Essa informação pode ser facilmente transmitida para o consumidor final através do cardápio interativo em $Q R$ Code, em que a descrição dos pratos contempla o nome do produtor. Nesse formato digital de cardápio, tendência pós COVID-19, o cliente tem a possibilidade 
de conhecer mais sobre quem e como seu alimento é feito, visualizar imagens, saber a escala de feiras ou plataformas de compras que os produtores participam, e potencializa a construção das relações analógicas e digitais.

Além de proporcionar um espaço de interação e informação, a plataforma leva o consumidor ao espaço de compras, com entrega programada ou retirada na loja física, e ainda permite a compra diretamente com o produtor. Com a expansão do mercado consumidor, os produtores conseguem viabilizar a fabricação de itens que possuem escala mínima relativamente elevada, oportunizando a ampliação dos seus negócios.

Outro quesito contemplado pela proposta é o entreposto de distribuição como loja física. O fato de existir um ponto comercial incrementa as possibilidades de venda direta, tanto ao consumidor final quanto aos próprios chefs, que têm, ao frequentar o espaço, a chance de se deparar com toda gama de insumos, e decidir pela compra. Permite também que haja um espaço para escoar excedentes de produção, e mesmo produtos que sejam cultivados em escala muito pequena para a plataforma digital, mas que têm espaço nas gôndolas do hub.

O acréscimo de produtores e restaurantes georreferenciados traz inúmeras vantagens para os três usuários contemplados. Para os produtores, saber onde estão localizados seus pares e clientes permite organizar as entregas coletivamente, otimizando o transporte, uma das maiores dificuldades apresentadas. Para o consumidor final, a localização dos restaurantes facilmente identificada permite que a escolha do local para sua refeição seja facilitada também pelo endereço, e, em escala, pode utilizar esse recurso mesmo fora de sua cidade.

Com os dados compilados, diversas oportunidades se apresentam para o uso da plataforma: anunciar como um pop-up a existência de excedentes de feira, em um formato de "xepa" virtual, o compartilhamento de receitas e técnicas, ênfase na divulgação da sazonalidade dos produtos, uma pluralidade de oportunidades de relacionamento e trocas.

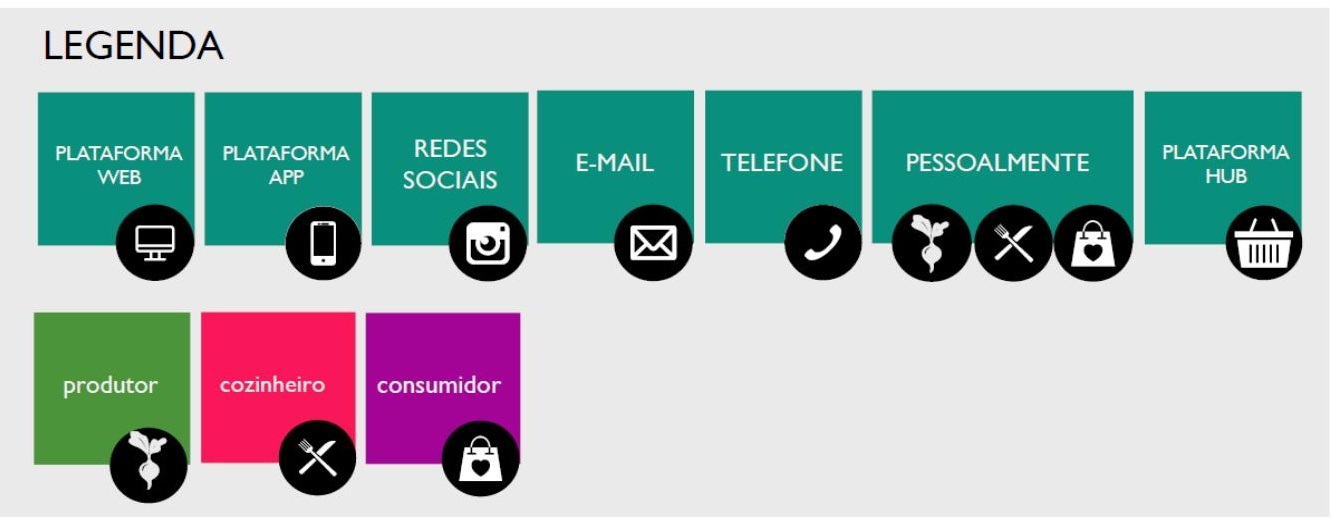


PRÉ SERVIÇO

ATIVIDADES
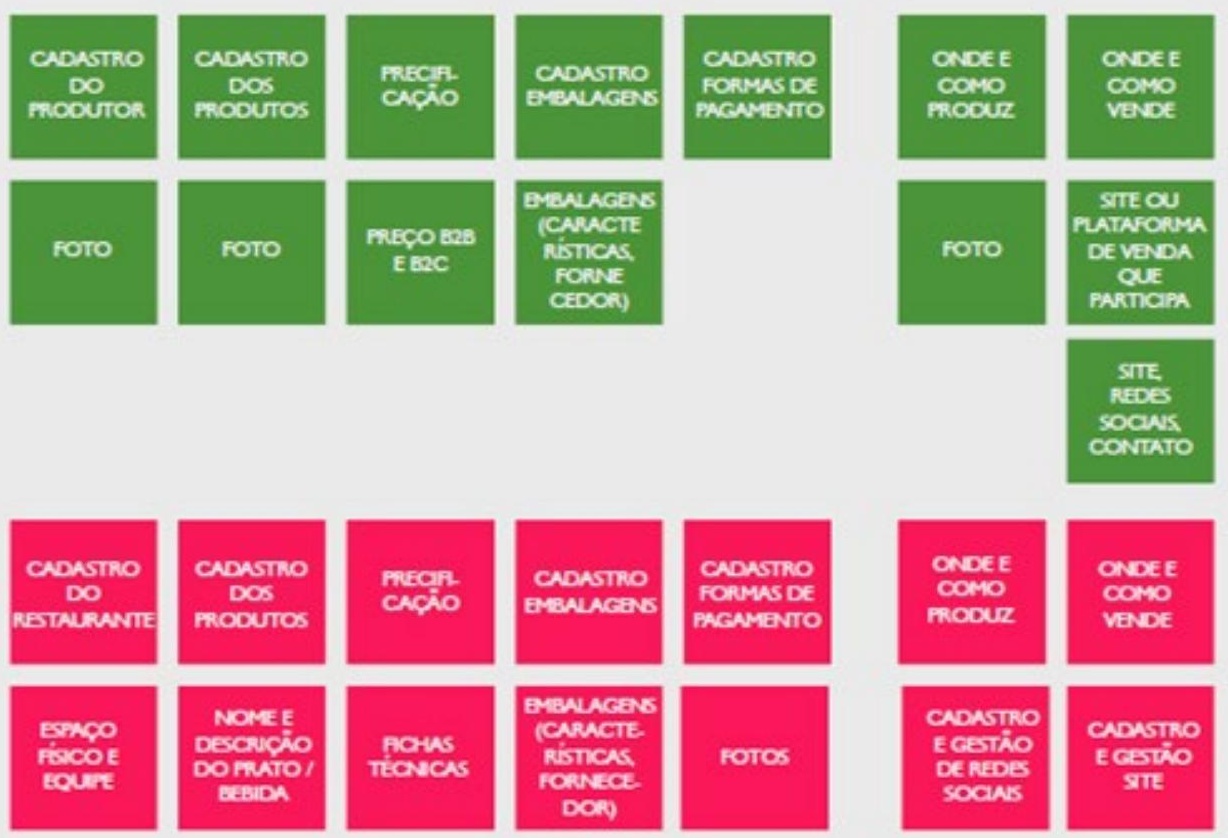

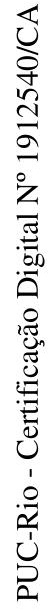

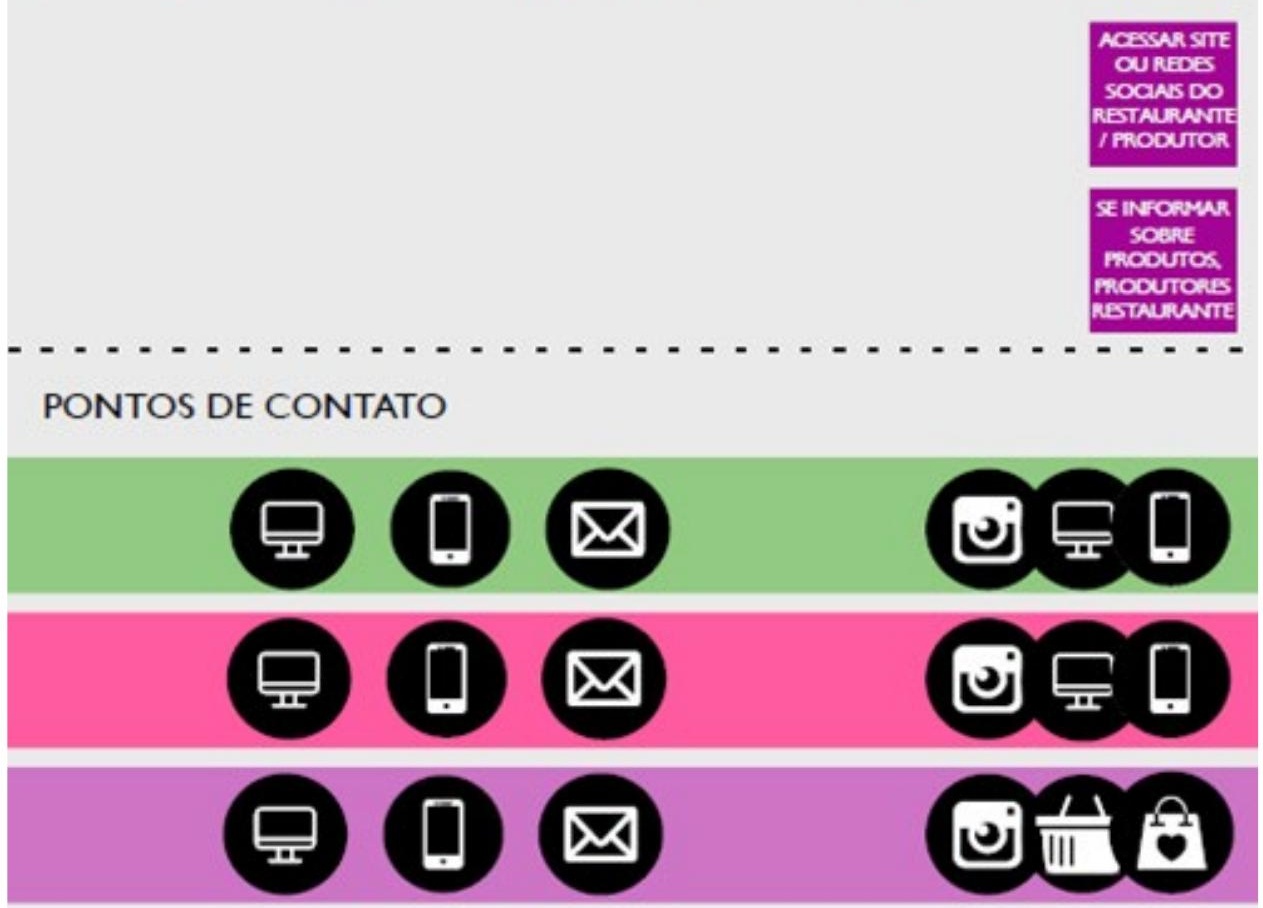




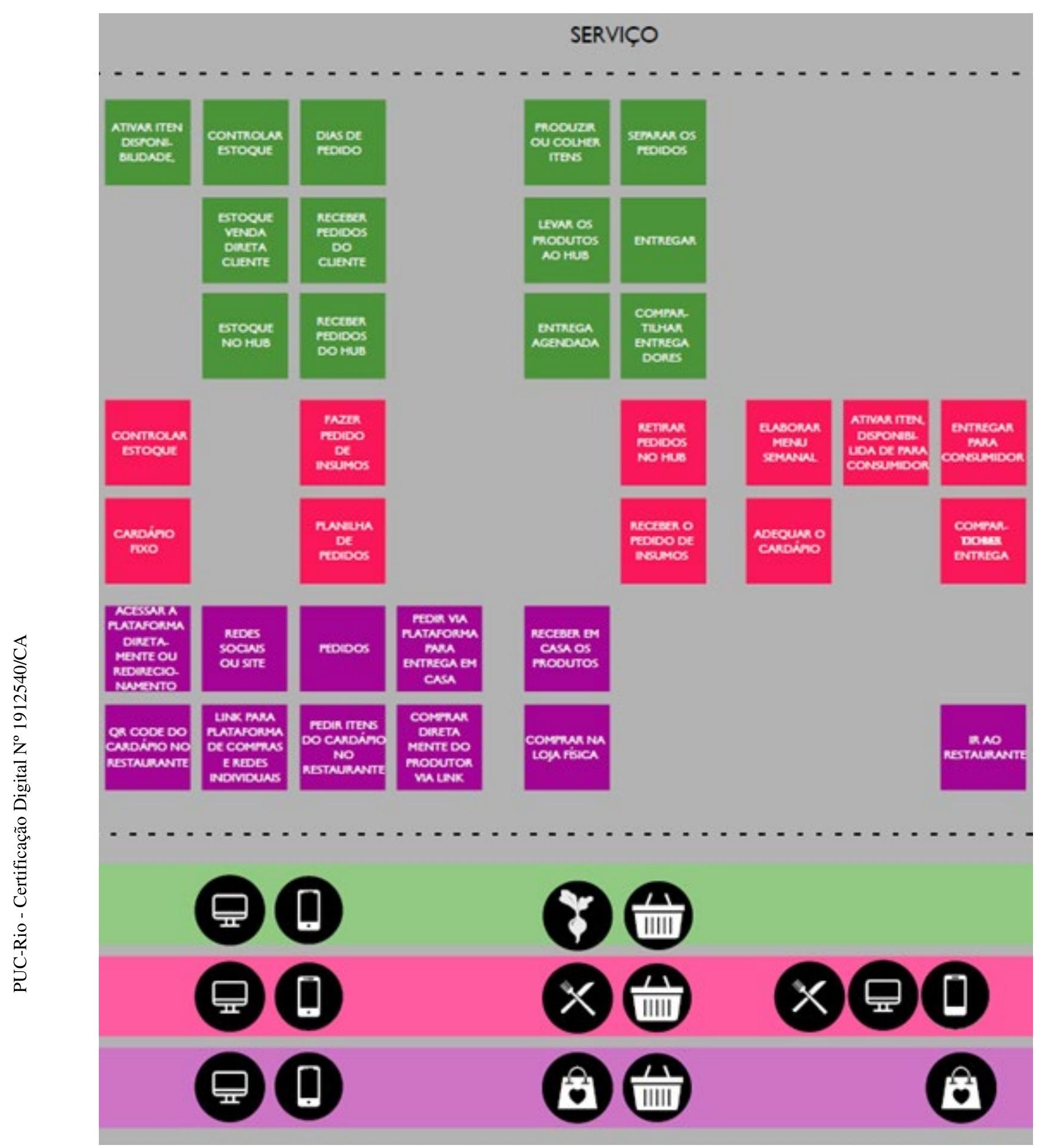




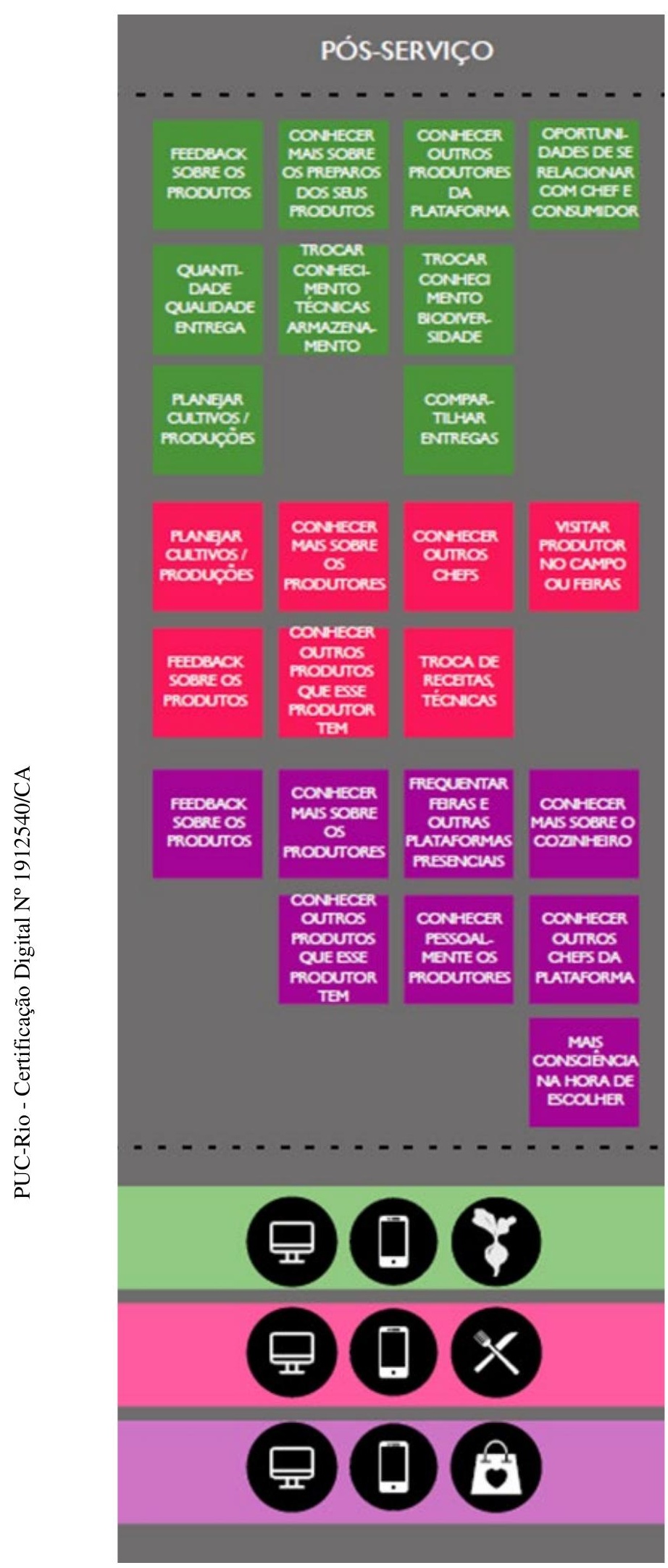

Figura 38 . Mapa de Jornada do Usuário 


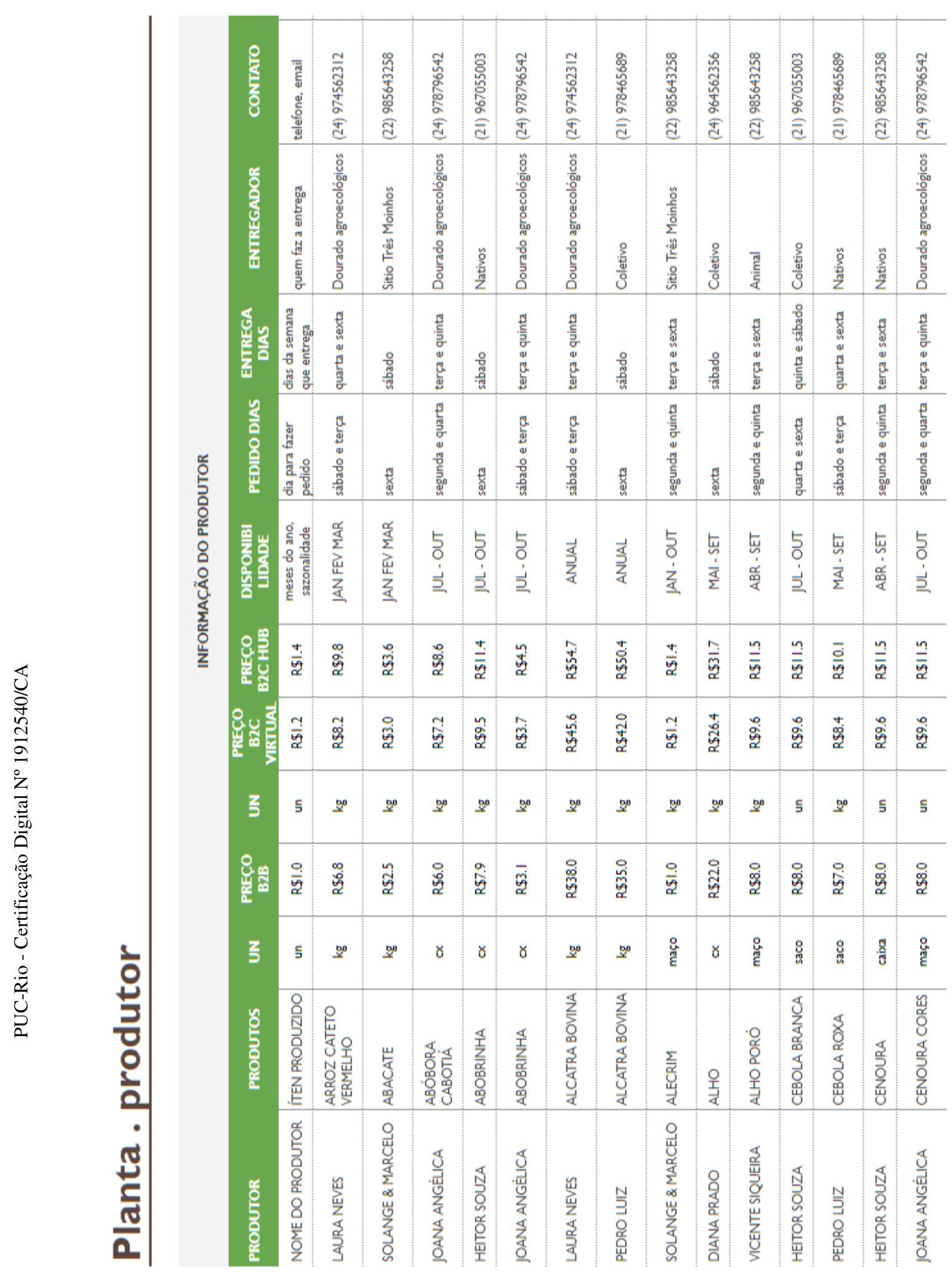

Figura 39a. Banco de dados produtor 


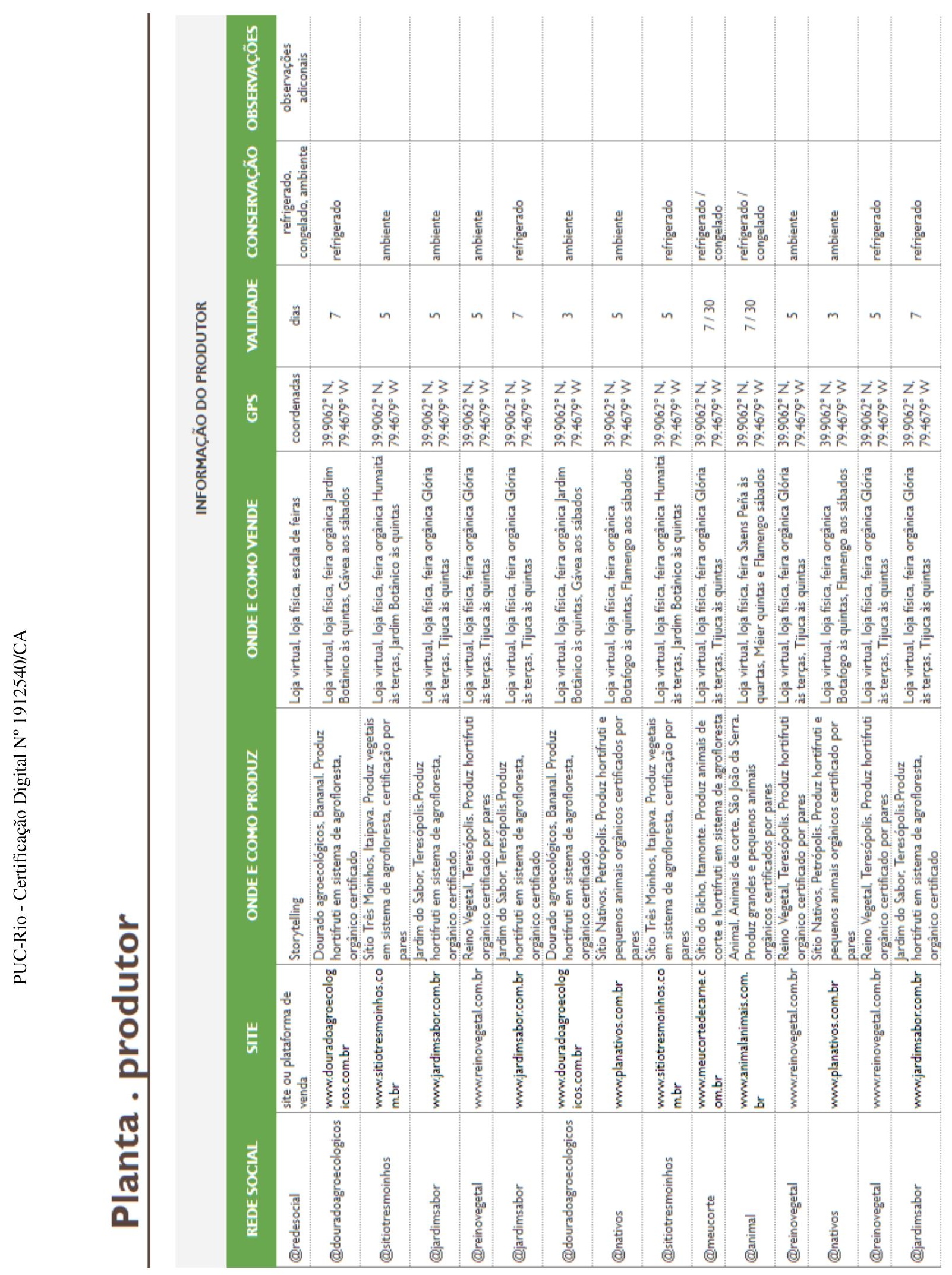

Figura 40 . Banco de dados produtor 


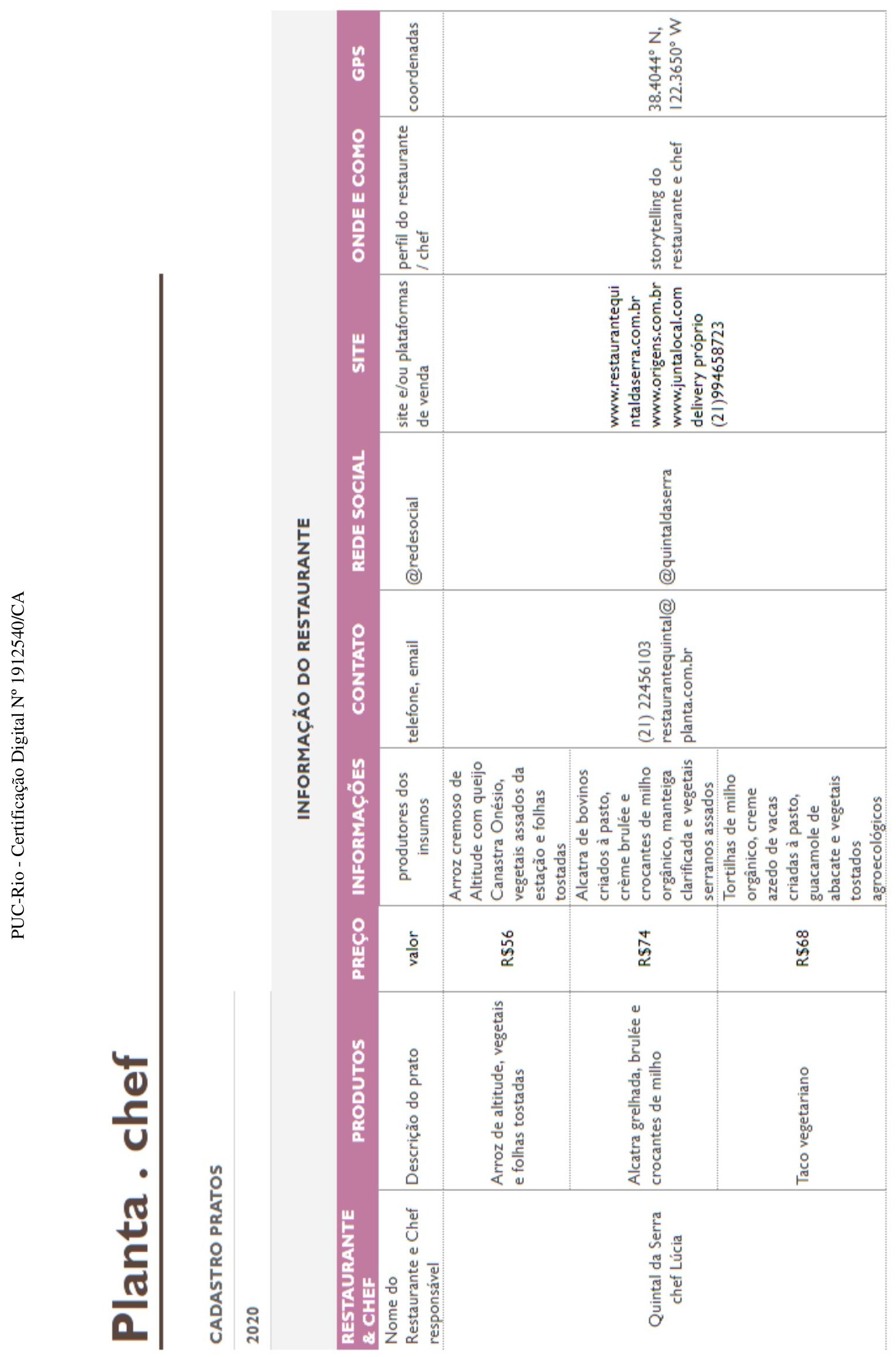

Figura 41 . Banco de dados cozinheiro/restaurante 


\section{Planta . chef}

\begin{tabular}{|c|c|c|c|c|c|}
\hline \multicolumn{2}{|l|}{2020} & \multirow[b]{2}{*}{$\begin{array}{c}\text { PREÇO } \\
\text { B2B }\end{array}$} & \multirow[b]{2}{*}{$\begin{array}{l}\text { NOME DO } \\
\text { PRATO }\end{array}$} & \multirow[b]{2}{*}{$\begin{array}{l}\text { NOME DO } \\
\text { PRATO }\end{array}$} & \multirow[b]{2}{*}{$\begin{array}{l}\text { NOME DO } \\
\text { PRATO }\end{array}$} \\
\hline \multirow[t]{2}{*}{ INGREDIENTE } & PRODUTOR & & & & \\
\hline & & & $\begin{array}{c}\text { Arroz de altitude, } \\
\text { vegetais e folhas } \\
\text { tostadas }\end{array}$ & $\begin{array}{c}\text { Alcatra grelhada, } \\
\text { brulée e crocantes } \\
\text { de milho }\end{array}$ & Taco vegetariano \\
\hline ABÓBORA CABOTIÁ & JOANA ANGÉLICA & $\mathrm{R} \$ 6.0$ & & & 0.1 \\
\hline ARROZ CATETO VERM & LAURA NEVES & $\mathrm{R} \$ 6.8$ & 0.1 & & \\
\hline ALCATRA BOVINA & PEDRO LUIZ & $\mathrm{R} \$ 35.0$ & & 0.2 & \\
\hline ALECRIM & SOLANGE \& MARCELC & $\mathrm{R} \$ 1.0$ & 0.05 & & \\
\hline ALHO PORÓ & VICENTE SIQUEIRA & $\mathrm{R} \$ 8.0$ & & 0.35 & 0.11 \\
\hline CEBOLA BRANCA & HEITOR SOUZA & $\mathrm{R} \$ 8.0$ & & & 0.01 \\
\hline ALHO PORÓ & VICENTE SIQUEIRA & $\mathrm{R} \$ 8.0$ & 0.05 & & 0.05 \\
\hline CENOURA & HEITOR SOUZA & $\mathrm{R} \$ 8.0$ & 0.1 & 0.2 & \\
\hline EMBALAGEM VIAGEM & FORNECEDOR & $\mathrm{R} \$ 0.9$ & I & 2 & 2 \\
\hline SACOLA KRAFT & FORNECEDOR & $\mathrm{R} \$ 0.2$ & I & I & $\mathbf{I}$ \\
\hline \multicolumn{2}{|l|}{ PORÇÕES UNITÁRIAS } & & 1 & I & I \\
\hline \multicolumn{2}{|l|}{ CUSTO TOTAL } & & $\$ 22.30$ & $\$ 24.63$ & $\$ 16.45$ \\
\hline \multicolumn{2}{|l|}{ PREÇO VENDA LOCAL } & & $\$ 63.00$ & $\$ 68.00$ & $\$ 48.00$ \\
\hline \multicolumn{2}{|c|}{ PREÇO VENDA DELIVERY } & & $\$ 69.00$ & $\$ 72.00$ & $\$ 53.00$ \\
\hline
\end{tabular}

Figura 42b. Banco de dados cozinheiro/restaurante

A informações fornecidas pelos usuários possibilitam feedbacks e interações em tempo real, ações coletivas como o compartilhamento de entregadores viabilizando inclusive a prática da logística reversa -, permitem compras coletivas como as de insumos e embalagens, e tornam acessíveis referências e contatos relevantes.

No quesito disponibilidade, tanto produtor quanto chef têm a possibilidade de trabalhar dentro de sua capacidade produtiva, ativando ou desativando os produtos conforme oferta e demanda. Esse modelo também permite promover produtos em supersafra, por exemplo, potencializando seu escoamento, e contando com liberdade na precificação.

Utilizando a navegação por produtor ou produto, consumidores finais e chefs podem escolher baseados em suas preferências de produtor, preço ou ainda quantidade disponível, quando o sistema distribui as vendas proporcionalmente à oferta. Para o restaurante, é muito valiosa a possibilidade de retroalimentação de fornecedores e valores praticados, que podem estar automaticamente vinculados às planilhas de Ficha Técnica, mantendo acuidade financeira. 


\section{Planta . consumidor}

\begin{tabular}{|c|c|c|c|c|}
\hline \multicolumn{5}{|c|}{$\begin{array}{l}\text { INFORMAÇÕES DO } \\
\text { CONSUMIDOR }\end{array}$} \\
\hline CONSUMIDOR & IDADE & CONTATO & REDE SOCIAL & FEEDBACK \\
\hline Nome & & telefone, email & @redesocial & feedback \\
\hline \multicolumn{5}{|c|}{$\begin{array}{l}\text { INFORMAÇÕES PARA O } \\
\text { CONSUMIDOR }\end{array}$} \\
\hline \multicolumn{2}{|c|}{ PRATO DO CARDÁPIC PREÇO } & DESCRIÇÃO & \multicolumn{2}{|l|}{ INGREDIENTES PRINCIPAIS } \\
\hline Descriçào do prato & valor & Descriçào do prato & \multicolumn{2}{|l|}{ Ingredientes rastreáveis } \\
\hline $\begin{array}{l}\text { Arroz de altitude, vegetais } \\
\text { e follhas tostadas }\end{array}$ & R\$56 & $\begin{array}{l}\text { Arroz cremoso de Altitude com } \\
\text { queijo Canastra Onésio, vegetais } \\
\text { assados da estacaào e folhas } \\
\text { tostadas }\end{array}$ & \multicolumn{2}{|c|}{$\begin{array}{l}\text { @jardimsabor @onesiopedrosa @wagnersantos @heitorsouza } \\
\text { @pedroluiz @marthafeitosa @solangeimarcelo }\end{array}$} \\
\hline $\begin{array}{l}\text { Alcatra grelhada, brulée e } \\
\text { crocantes de milho }\end{array}$ & RS74 & $\begin{array}{l}\text { Alcatra de bovinos criados à pasto, } \\
\text { crème brulée e crocantes de milho } \\
\text { orgánico, manteiga clarificada e } \\
\text { vegetais serranos assados }\end{array}$ & \multicolumn{2}{|c|}{$\begin{array}{l}\text { @sitiotresmoinhos@reinovegetal @animal @nativos } \\
\text { @jardimsabor @hortidourado }\end{array}$} \\
\hline Taco vegetariano & R\$68 & $\begin{array}{l}\text { Tortilhas de milho organico, creme } \\
\text { azedo de vacas criadas à pasto, } \\
\text { guacamole de abacate e vegetais } \\
\text { tostados agroecológicos }\end{array}$ & \multicolumn{2}{|c|}{$\begin{array}{l}\text { @sitiotresmoinhos @jardimsabor @hortidourado @animal } \\
\text { @reinovegetal }\end{array}$} \\
\hline
\end{tabular}

\begin{tabular}{|c|c|c|c|c|}
\hline PRODUTOS & $\begin{array}{l}\text { PREÇO } \\
\text { B2C }\end{array}$ & PRODUTOR & OUTROS PRODUTOS & ONDE VENDE \\
\hline Ingrediente in natura & valor & Nome do Produtor & Outros itens produzidos & $\begin{array}{l}\text { Loja virtual, loja física, } \\
\text { escala de feiras }\end{array}$ \\
\hline ABÓBORA CABOTIÁ & RS6 & JOANA ANGÉLICA & $\begin{array}{l}\text { abóbora cabotiá, abóbora menina, } \\
\text { batata branca, batata doce roxa, } \\
\text { batata doce cenoura, aipím, } \\
\text { maracujả. péssego }\end{array}$ & $\begin{array}{l}\text { Loja virtual, loja fisica, } \\
\text { feira orgánica Gloria às } \\
\text { terças, Tijuca às quintas }\end{array}$ \\
\hline ABOBRINHA & R\$8 & HEITOR SOUZA & $\begin{array}{l}\text { abobrinha, broto de } \\
\text { beterraba,cebola roxa, cenoura } \\
\text { baby, chicória, erva-doce }\end{array}$ & $\begin{array}{l}\text { Loja virtual, loja fisica, } \\
\text { feira orgảnica Glória às } \\
\text { terças, Tijuca às quintas }\end{array}$ \\
\hline ALCATRA BOVINA & R\$35 & PEDRO LUIZ & $\begin{array}{l}\text { abobrinha, broto de } \\
\text { beterraba,cebola roxa, cenoura } \\
\text { baby, chicória, erva-doce }\end{array}$ & $\begin{array}{l}\text { Loja virtual, loja fisica, } \\
\text { feira orgánica Botafogo as } \\
\text { quintas, Flamengo aos } \\
\text { sábados }\end{array}$ \\
\hline ALECRIM & RSI & SOLANGE \& MARCELO & $\begin{array}{l}\text { abobrinha, broto de } \\
\text { beterraba,cebola roxa, cenoura } \\
\text { baby, chicória, erva-doce }\end{array}$ & $\begin{array}{l}\text { Loja virtual, loja fisica, } \\
\text { feira orgảnica Humaita as } \\
\text { terças, Jardim Botånico as } \\
\text { quintas }\end{array}$ \\
\hline ALHO & $R \$ 22$ & DIANA PRADO & $\begin{array}{l}\text { abobrinha, broto de } \\
\text { beterraba,cebola roxa, cenoura } \\
\text { baby, chicória, erva-doce }\end{array}$ & $\begin{array}{l}\text { Loja virtual, loja fisica, } \\
\text { feira orgânica Glória as } \\
\text { terças, Tijuca às quintas }\end{array}$ \\
\hline ALHO PORO & R\$8 & VICENTE SIQUEIRA & $\begin{array}{l}\text { abobrinha, broto de } \\
\text { beterraba,cebola roxa, cenoura } \\
\text { baby, chicória, erva-doce }\end{array}$ & $\begin{array}{l}\text { Loja virtual, loja física, } \\
\text { feira Saens Peña às } \\
\text { quartas, Méier quintas e } \\
\text { Flamengo sábados }\end{array}$ \\
\hline CEBOLA BRANCA & RS8 & HEITOR SOUZA & $\begin{array}{l}\text { abobrinha, broto de } \\
\text { beterraba,cebola roxa, cenoura } \\
\text { baby, chicória, erva-doce }\end{array}$ & $\begin{array}{l}\text { Loja virtual, loja fisica, } \\
\text { feira organica Gloria às } \\
\text { terças, Tijuca às quintas }\end{array}$ \\
\hline CEBOLA ROXA & R\$7 & PEDRO LUIZ & $\begin{array}{l}\text { abobrinha, broto de } \\
\text { beterraba,cebola roxa, cenoura } \\
\text { baby, chicória, erva-doce }\end{array}$ & $\begin{array}{l}\text { Loja virtual, loja fisica, } \\
\text { feira orgânica Botafogo às } \\
\text { quintas, Flamengo aos } \\
\text { sábados }\end{array}$ \\
\hline CENOURA & R58 & HEITOR SOUZA & $\begin{array}{l}\text { abobrinha, broto de } \\
\text { beterraba,cebola roxa, cenoura } \\
\text { baby, chicória, erva-doce }\end{array}$ & $\begin{array}{l}\text { Loja virtual, loja física, } \\
\text { feira orgänica Glória às } \\
\text { terças, Tijuca às quintas }\end{array}$ \\
\hline CENOURA CORES & R58 & JOANA ANGÉLICA & $\begin{array}{l}\text { abobrinha, broto de } \\
\text { beterraba,cebola roxa, cenoura } \\
\text { baby, chicória, erva-doce }\end{array}$ & $\begin{array}{l}\text { Loja virtual, loja fisica, } \\
\text { feira orgainica Glöria às } \\
\text { terças, Tijuca às quintas }\end{array}$ \\
\hline
\end{tabular}

Figura 44 . Banco de dados consumidor 


\subsection{Prototipação}

Ainda dentro da metodologia proposta pela MJV (Vianna et al., 2012), entende-se que um protótipo é a concretização das ideias, uma forma de representar o que foi desenhado e promover validações. No caso apresentado, através de simulação gráfica. Nessa pesquisa, as propostas foram validadas pelos pares, chefs e produtores convidados para as rodadas de discussão, chegando a algumas proposições finais mais assertivas e factíveis na realidade local.

O nome Planta remete ao ato de semear ou dar início a algo; fixar-se à terra; à representação das ideias de um projeto, e, naturalmente, às espécies vegetais, base da alimentação onívora. Foi adotada uma representação visual simples e despretensiosa, uma inspiração gráfica para fins de representação nas simulações. A fonte principal utilizada foi a Gill Sans Nova, tendo como fonte de apoio a Gill Sans Condensed.

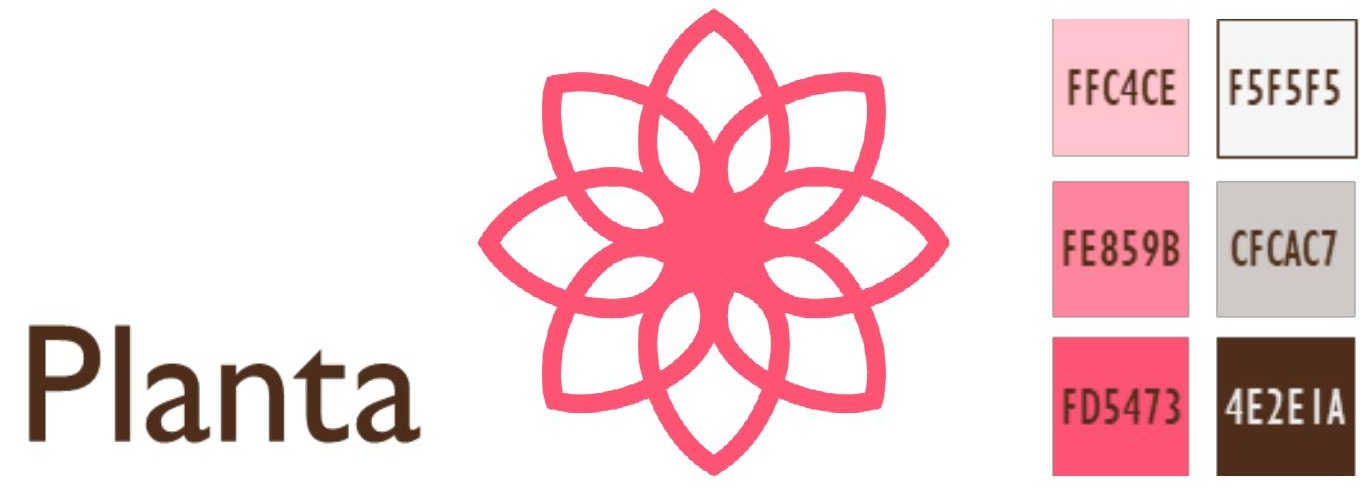

Figura 45 . Representação visual e paleta de cores Planta

O critério de seleção dos chefs/restaurantes a serem convidados para a plataforma é a de pertencerem ao grupo dos Ecochefs. Esse modelo de curadoria, que já possui uma carta de princípios e práticas bem fundamentada, possibilita agregar valor e escalonar o serviço, permitindo que seja replicado em qualquer território em que atue um Ecochef, utilizando as redes de produtores e chefs locais, afiliados. Dado que a base do serviço projetado são as relações humanas, ser parte de um grupo de chefs que se conhecem pessoalmente e compartilham ideais de sustentabilidade, respeito aos produtores e produtos é fundamental.

A simulação do serviço foi feita utilizando-se o modelo da Junta Local sistema on-line de compras e feiras presenciais; e a rede de Ecochefs anteriormente mencionada, composta por cerca de 50 profissionais, em sua maioria cariocas, mas já em expansão para outros territórios, como substrato de chefs catalogados. Nessa simulação utilizou-se também a loja A Colheita como entreposto de coleta e 
distribuição, além de explorar as vantagens da loja física. A escolha dessas mídias se deu pelos seguintes motivos:

- Familiaridade da pesquisadora com a Junta Local e com o sistema da Sacola Virtual como consumidora e produtora afiliada;

- Relação próxima com a coordenação dos Ecochefs;

- Boa relação dos Ecochefs com a Junta Local, possibilidade de futuras parcerias;

- Mercado A Colheita participa esporadicamente das feiras da Junta Local, pois compartilham dos mesmos ideais e têm muitos produtores em comum;

- Interesse dos sócios da Junta Local e da A Colheita em otimizar as vendas e serviços já prestados, de maneira informal, a alguns restaurantes, vários deles participantes da rede dos Ecochefs;

- Prática, ainda irregular, de workshops e degustações na A Colheita, com o intuito de apresentar produtores, seus produtos e promover a troca de saberes e experiências.

As interações no Planta acontecem entre produtor-chef, chef-consumidor e consumidor-produtor, também intra-chefs e intra-produtores; em instâncias simultâneas ou assíncronas. Todas as interfaces propostas podem representar o momento inicial de contado entre os atores. O sistema Planta contempla as seguintes evidências de serviço:

- Loja física: funciona como um entreposto para as entregas, mercado de atacado e varejo; oferece possibilidade de interação de todos os atores envolvidos no ato da entrega, compra, e como espaço para workshops, degustação e interface relacional;

- Feiras: momento de grande troca relacional, em que produtor e cliente (consumidor final e chef) têm a possibilidade de fazer um intercâmbio de informações técnicas e sensoriais; é também uma oportunidade de agregar valor e promover o consumo mais consciente. Nas feiras gastronômicas, o papel de produtor também cabe ao chef, como beneficiador de alimentos, que oferece ao consumidor final pratos preparados por sua equipe, com insumos dos pequenos produtores;

- Plataforma digital: habilitada em três formatos distintos:

- um e-commerce que atende produtores e chefs/restaurantes, onde contam sua história, falam sobre o local, quem e como faz, e disponibilizam seus produtos para venda; 
- uma loja on-line onde os chefs realizam suas compras com uma vasta gama de produtores de modo centralizado, em formato atacado, adequando quantidade, formas de pagamento e entrega à demanda em larga escala;

- uma loja on-line para consumidores finais, que têm através da plataforma a oportunidade de comprar itens de diversos produtores, acessar informações sobre a origem de seus alimentos e escolher entre receber sua compra em casa ou retirar na loja.

Muito além de um site de compras, a loja on-line oferece referências sobre a origem dos produtos, do produtor, restaurante, chef, links para outros canais interação (como escala de feiras, website, redes sociais, aplicativos de entrega), criando mais oportunidades de relacionamento e comércio entre os atores.

- Cardápio digital: a implementação dos cardápios com acesso por QR Code potencializada pelos protocolos sanitários advindos do COVID-19 traz inúmeras possibilidades de compartilhamento de informações. Além de oferecer dados sobre o restaurante, chef e pratos/bebidas disponíveis, o cardápio digital permite que o consumidor explore outras camadas acerca dos elementos oferecidos no estabelecimento. A descrição dos itens do cardápio enfatiza a origem dos ingredientes, e de modo interativo, o consumidor é levado até a plataforma digital do Planta, fechando o ciclo, ou ainda até o website de um produtor em particular.

Embora não faça parte do escopo do Planta, o contato do consumidor no Restaurante é parte do processo. É o momento em que acontece a apresentação dos produtos beneficiados ao consumidor final, despertando interesse e oferecendo oportunidades de conexão com produtores e outros chefs participantes da plataforma. É dada, ao consumidor final, a possibilidade de saber mais sobre a origem de seu alimento, interpelar presencialmente a equipe de serviço do restaurante, e tomar conhecimento da rede suportada pelo Planta.

A proposta para essa plataforma é de ser uma das diversas formas de contato e relação entre os atores, funcionando menos como um atravessador e mais como uma maneira de desintermediar, conectando e cobrando de maneira justa e transparente as despesas operacionais e lucro pertinente. As cifras podem variar consideravelmente de um modelo de negócio para outro, como se vê em uma gama de serviços de e-commerce já existentes.

Para esse exercício, foi adotada uma mensalidade fixa para os produtores e restaurantes, acrescida do valor de $20 \%$ sobre as vendas realizadas através do 
Planta. Para equalizar a mobilização gerada por produtores e restaurantes com maior volume financeiro de vendas, a mensalidade é decupada em 5 faixas de valor, proporcional à renda. O foco primordial nesse modelo de negócio não é o lucro máximo, mas sim a sustentabilidade em todos seus vieses e a ética. A Figura 42 mostra a síntese do modelo de negócios adotada.
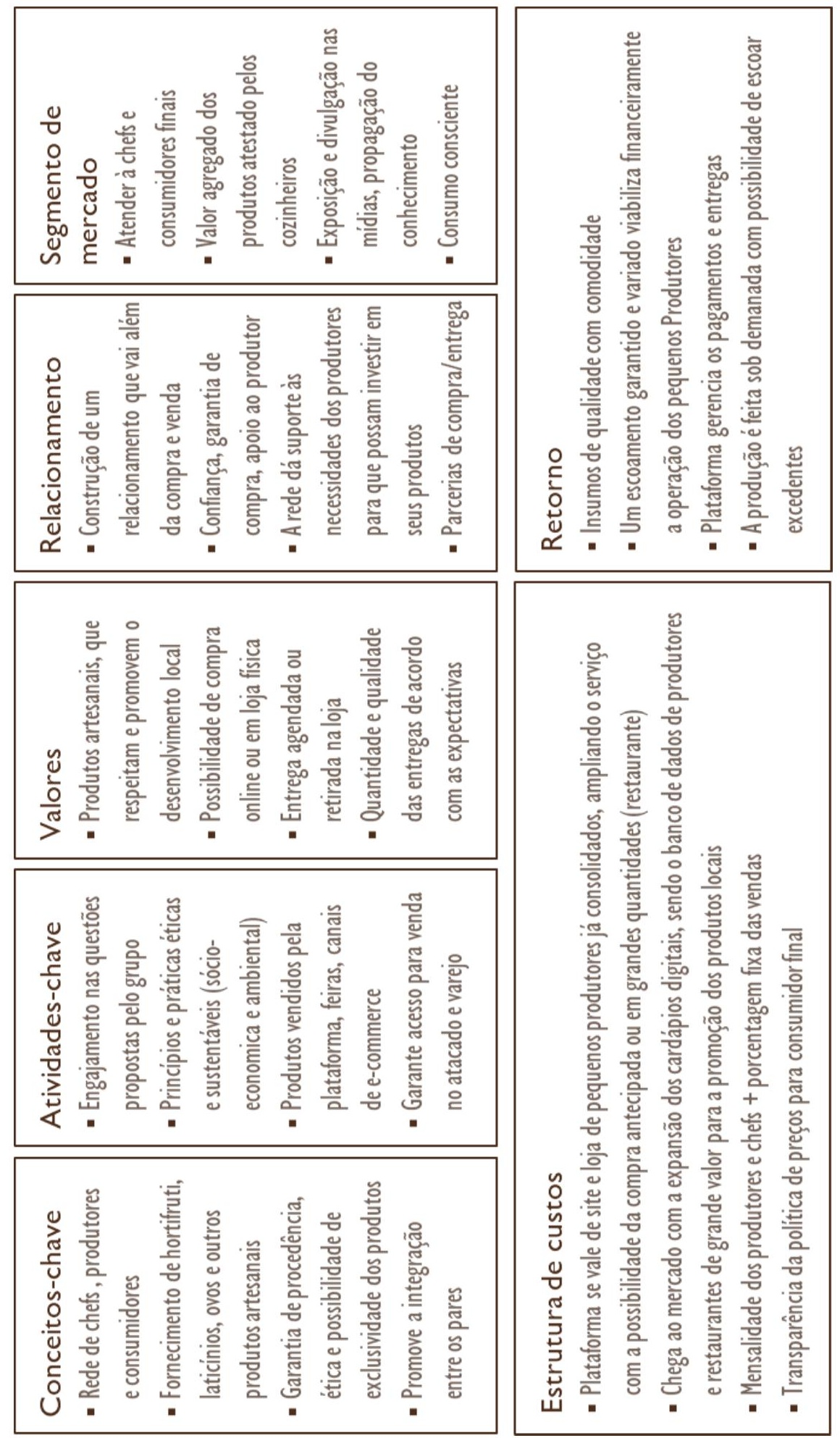

Figura 46 . Business Model Canvas 
Para melhor visualização do serviço proposto, foram criados storyboards, ou representações imagéticas da sequência de ações que representam a execução do serviço proposto (Vianna et al., 2014). Considerando a amplitude do projeto, cada ator terá uma sequência de ações representadas, que podem ou não ocorrer concomitantemente.

\section{me. confeitaria}

marshmallows saborizados, crème caramel,

caramelo salgado, madeleines

2 Mari, Ellen \& Marcello

Botafogo, Rio de Janeiro - RJ

f me.confeitariaartesanal

(0) me.confeitaria

9 www.meconfeitaria.com

Era uma vez três arquitetos que amam arquitetura, mas um monte de outros troços também.

A Ellen adora uma culinária francesa. A Mari adora uma confeitaria. O Marcello adora pessoas e fazer contas.

Quando os três resolveram se juntar deu no que só poderia ter dado: uma confeitaria com um pé na França e outro no Brasil, com quitutes feitos da
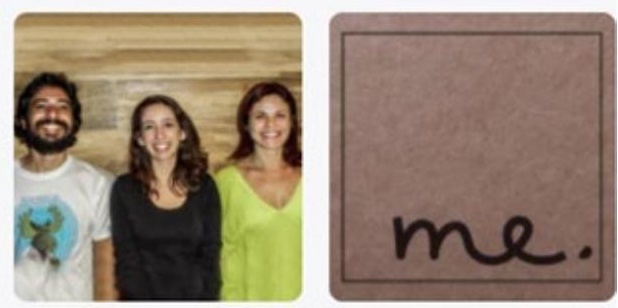

1. Cadastro do Produtor, foto

2. Onde e como produz, fotos

3. Onde e como vende, fotos

4. Site, plataformas de venda, redes sociais, contatos

É para comer sozinho. É para acompanhar um cafezinho. Ou quem sabe um chá. É para devorar na hora. É para dar de presente. É especialmente para você. Do jeito que você quiser.

me. 


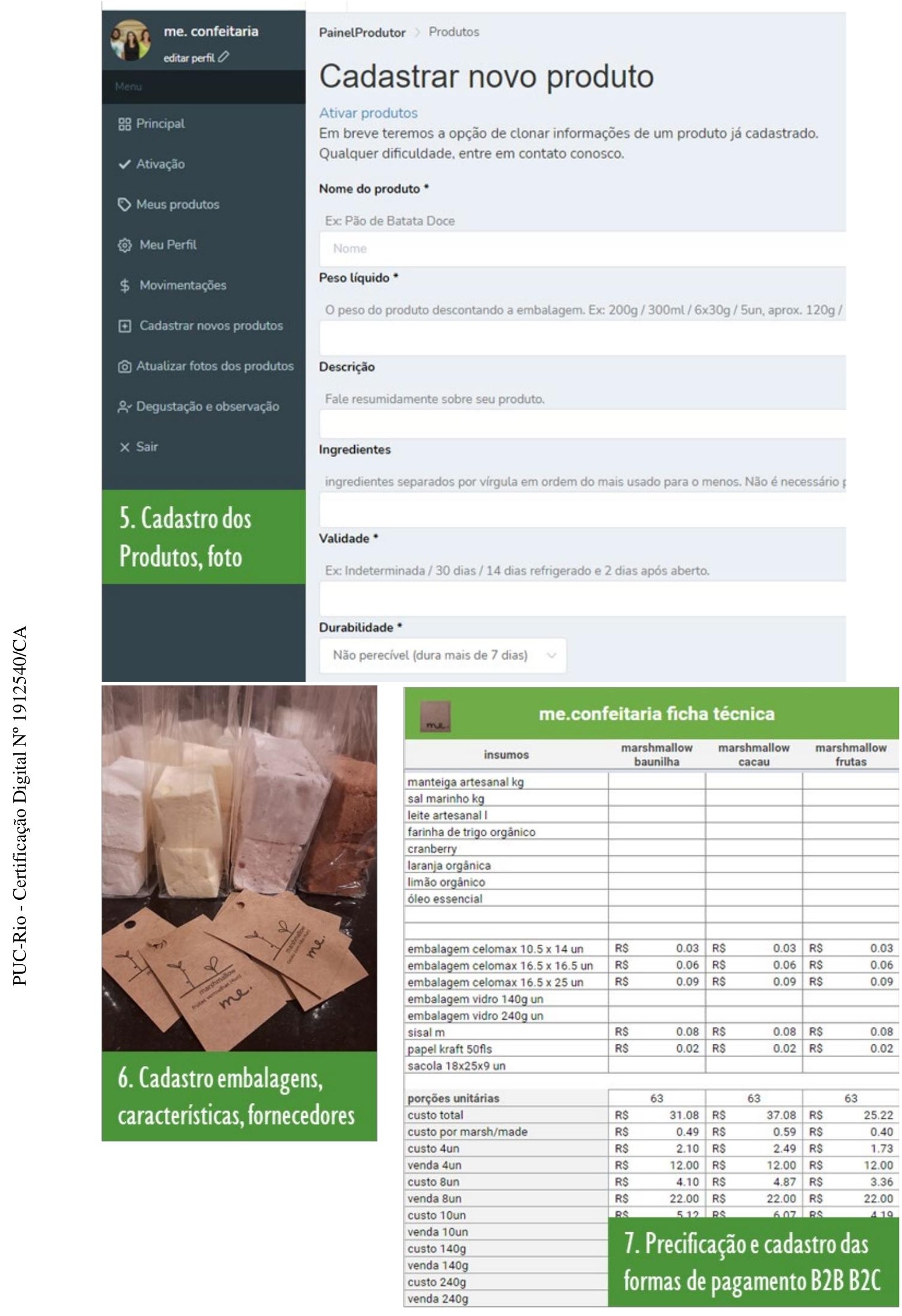




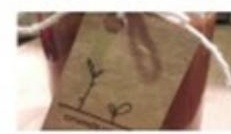

Caramelo com Sal

$240 \mathrm{~g}$ padaria e confeitaria
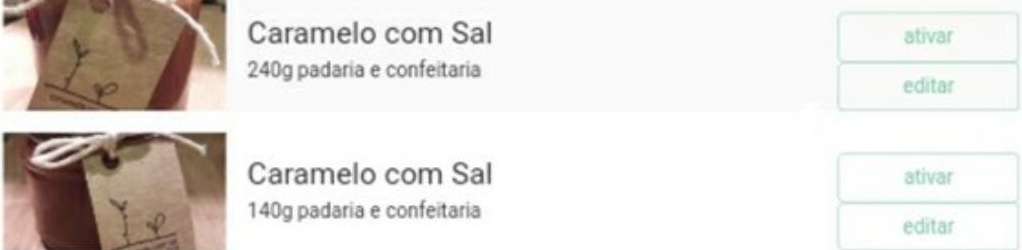

Caramelo com Sal

$140 \mathrm{~g}$ padaria e confeitaria

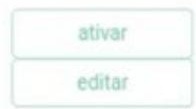

- Crème Caramel

$140 \mathrm{~g}$ padaria e confeitaria
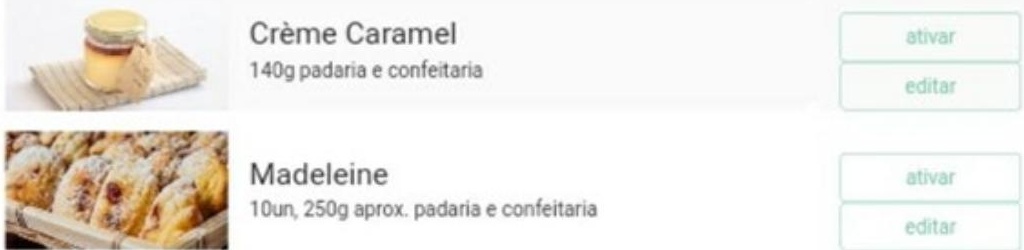

Madeleine

$10 \mathrm{un}, 250 \mathrm{~g}$ aprox. padaria e confeitaria
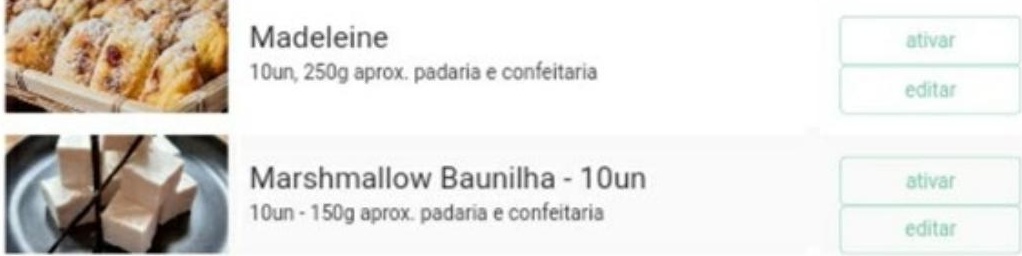

Marshmallow Baunilha - 10un

10 un $-150 \mathrm{~g}$ aprox. padaria e confeitaria
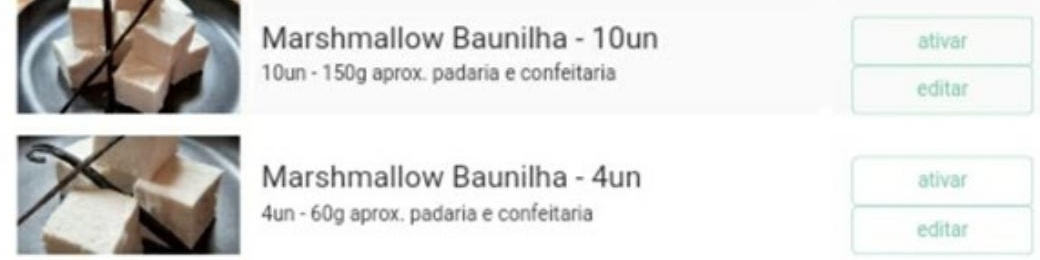

Marshmallow Baunilha - 4un

4un $-60 \mathrm{~g}$ aprox, padaria e confeitaria
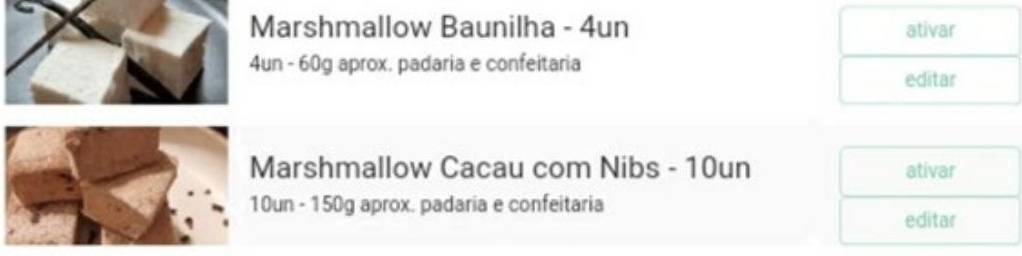

Marshmallow Cacau com Nibs - 10 un

$10 \mathrm{un} \cdot 150 \mathrm{~g}$ aprox. padaria e confeitaria

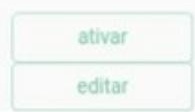

Marshmallow Cacau com Nibs - 4un

4un - $60 \mathrm{~g}$ aprox. padaria e confeitaria

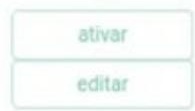

Marshmallow Café Masala - 10un

$10 \mathrm{un}-150 \mathrm{~g}$ aprox. padaria e confeitaria

ativar

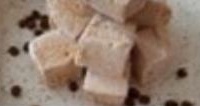

editar

Marshmallow Citrus - 10un

$10 \mathrm{un} \cdot 150 \mathrm{~g}$ aprox. padaria e confeitaria

8. Ativação dos produtos 


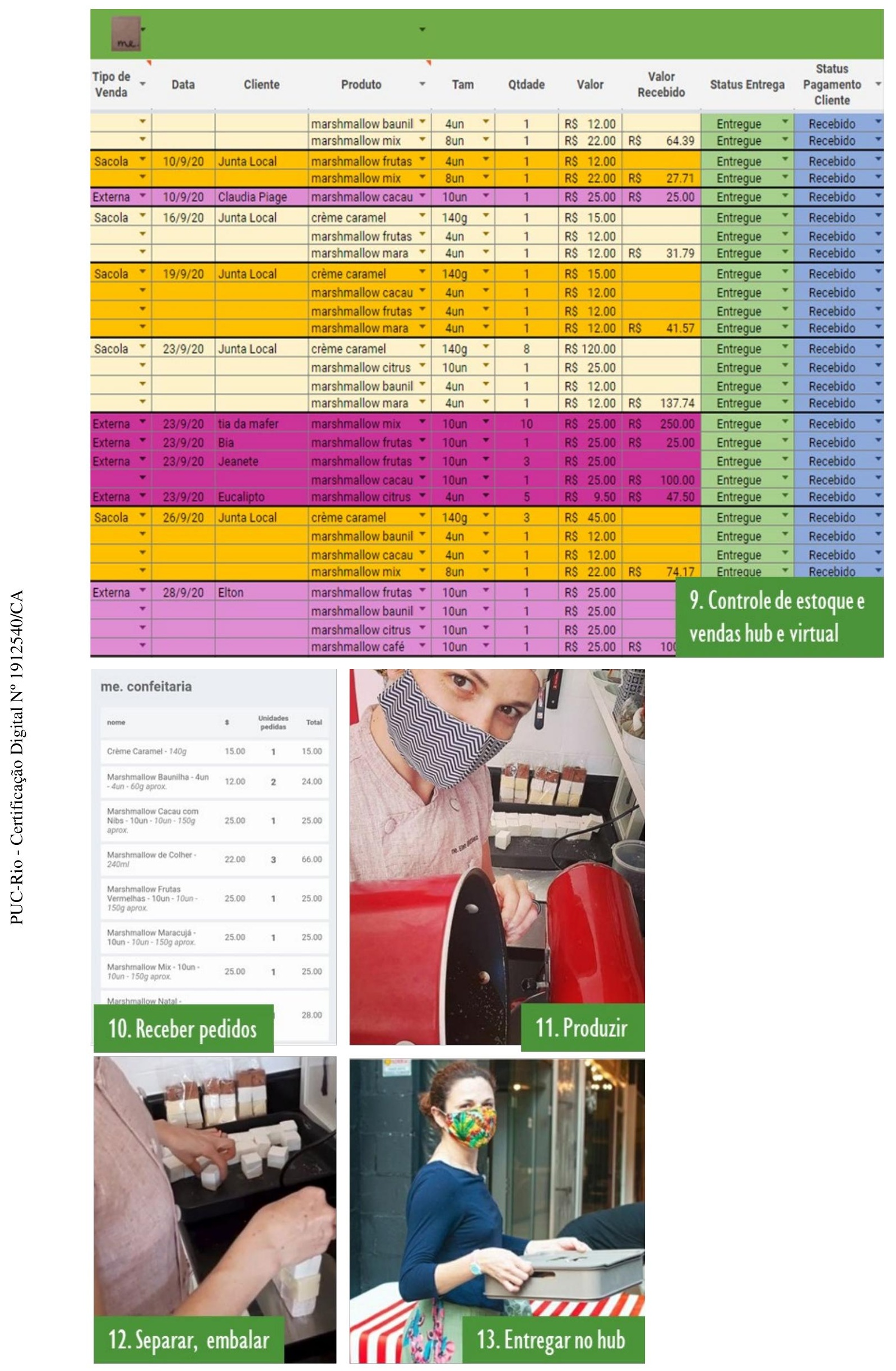




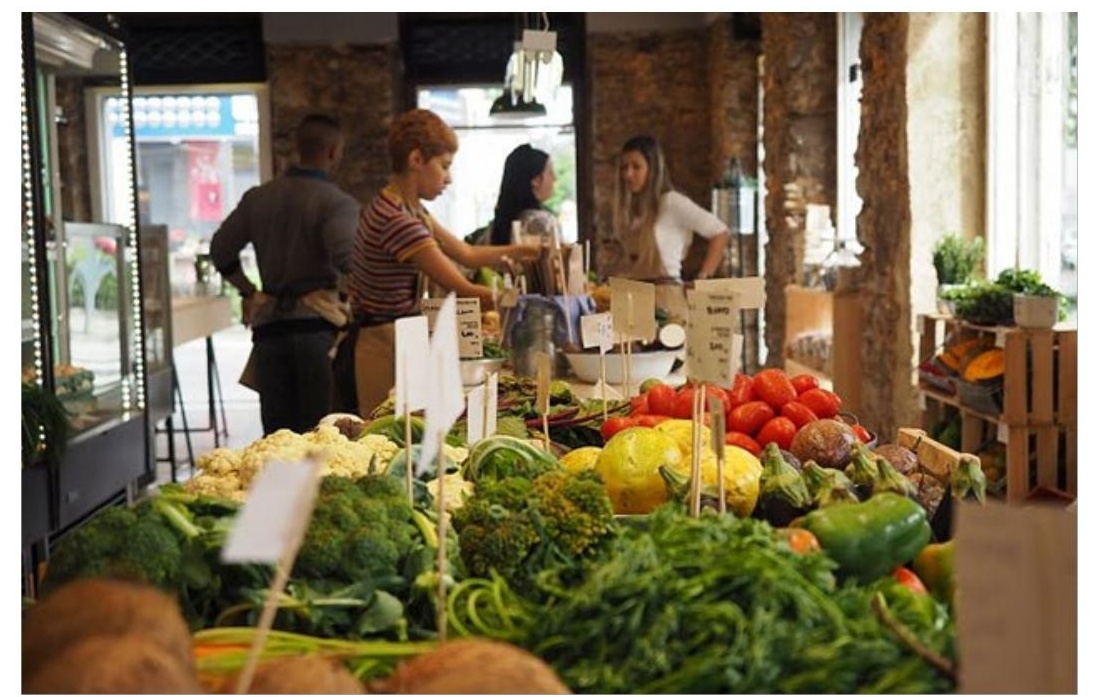

14. Feedback dos clientes sobre produtos e entregas

15. Relacionamento com chefs e consumidores, troca de saberese técnicas, possibilidade de planejar cultivos/produção

16. Relacionamento com outros produtores para trocas culturais e técnicas (loja física, feiras, encontros)
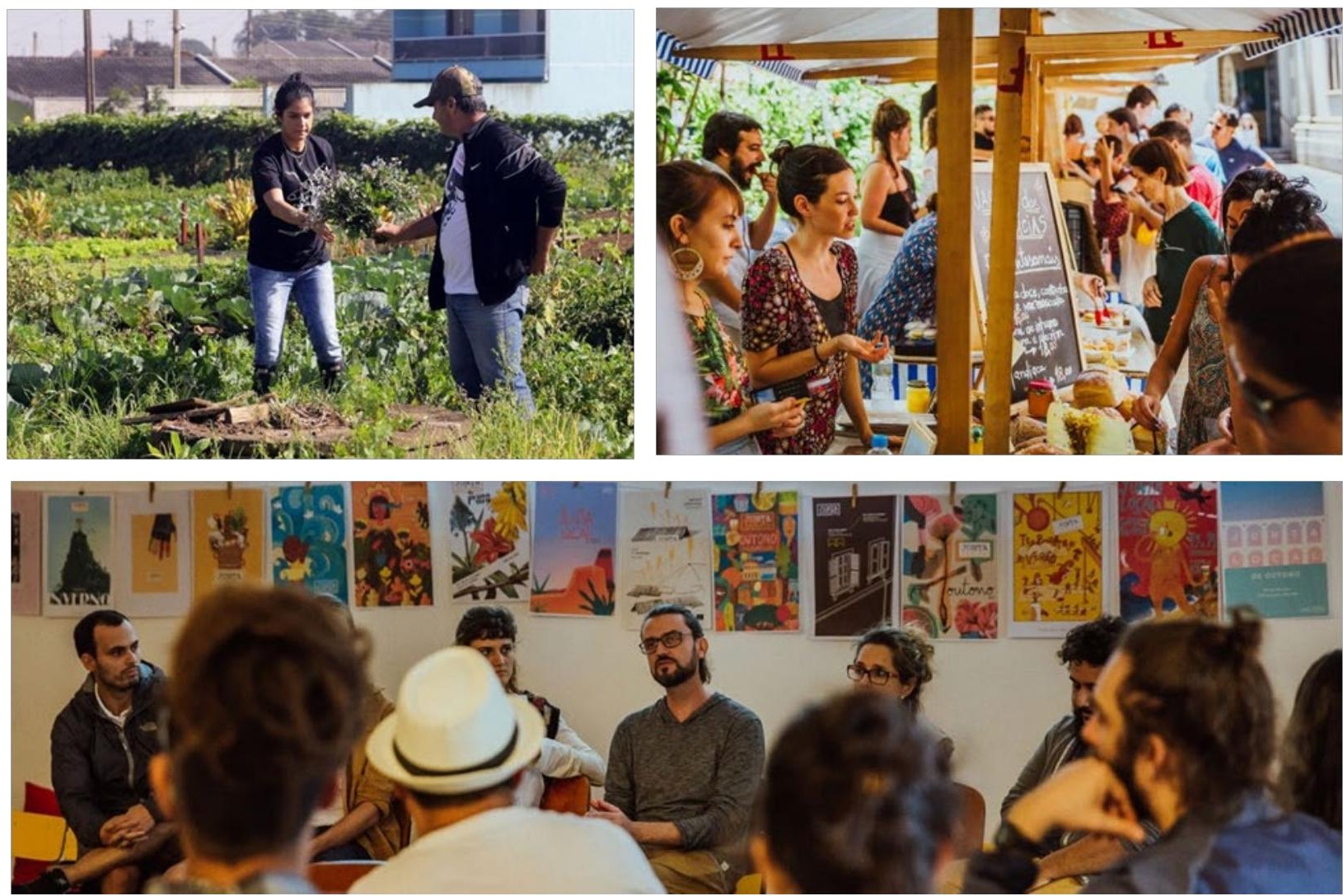

Figura 47 . Storyboard produtor 


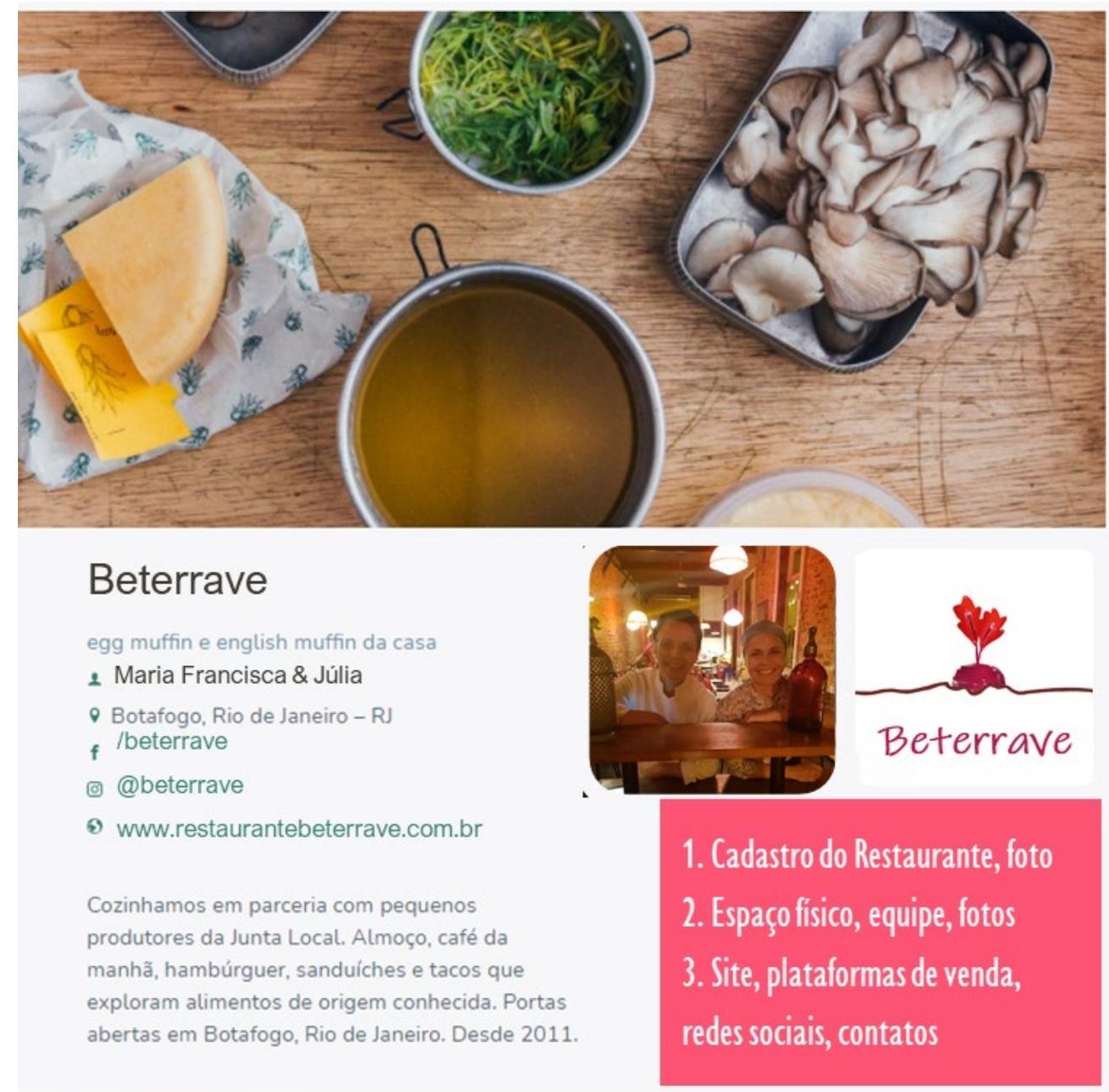

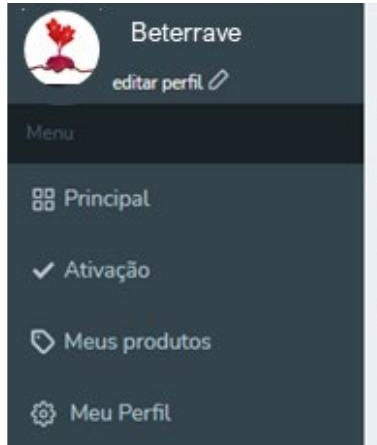

\$ Movimentaçōes

-1 Cadastrar novos produtos

[0] Atualizar fotos dos produtos

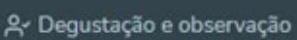

$\times$ Sair

4. Nome dos pratos, ingredientes, fotos
PainelProdutor Produtos

\section{Cadastrar novo produto}

Ativar produtos

Em breve teremos a opção de clonar informações de um produto já cadastrado. Qualquer dificuldade, entre em contato conosco.

Nome do produto ${ }^{*}$

Ex: Pão de Batata Doce

Nome

Peso líquido *

O peso do produto descontando a embalagem. Ex: $200 \mathrm{~g} / 300 \mathrm{ml} / 6 \times 30 \mathrm{~g} / 5 \mathrm{un}$, aprox. $120 \mathrm{~g}$

\section{Descrição}

Fale resumidamente sobre seu produto.

Ingredientes

ingredientes separados por vírgula em ordem do mais usado para o menos. Não é necessári

Validade *

Ex: Indeterminada / 30 dias / 14 dias refrigerado e 2 dias após aberto.

\section{Durabilidade *}

Não perecivel (dura mais de 7 dias) 
FICHAS TÉCNICAS

2020

\begin{tabular}{|c|c|c|c|c|c|}
\hline INGREDIENTE & PRODUTOR & $\begin{array}{l}\text { PRECCO } \\
\text { B2B }\end{array}$ & $\begin{array}{l}\text { NOME DO } \\
\text { PRATO }\end{array}$ & $\begin{array}{l}\text { NOME DO } \\
\text { PRATO }\end{array}$ & $\begin{array}{l}\text { NOME DO } \\
\text { PRATO }\end{array}$ \\
\hline & & & $\begin{array}{l}\text { Arroz de altitude, } \\
\text { vegetais e folhas } \\
\text { tostadas }\end{array}$ & $\begin{array}{c}\text { Alcatra grelhada, } \\
\text { brulée e crocantes } \\
\text { de milho }\end{array}$ & Taco vegetariano \\
\hline ABÓBORA CABOTĹ́ & JOANA ANGÉLICA & $R \$ 6.0$ & & & 0.1 \\
\hline ARROZ CATETO VERN & LAURA NEVES & $\mathrm{R} \$ 6.8$ & 0.1 & & \\
\hline ALCATRA BOVINA & PEDRO LUIZ & $R \$ 35.0$ & & 0.2 & \\
\hline ALECRIM & SOLANGE \& MARCELC & $\mathrm{R} \$ 1.0$ & 0.05 & & \\
\hline ALHO PORÓ & VICENTE SIQUEIRA & $\mathrm{R} \$ 8.0$ & & 0.35 & 0.11 \\
\hline CEBOLA BRANCA & HEITOR SOUZA & $\mathrm{R} \$ 8.0$ & & & 0.01 \\
\hline ALHO PORÓ & VICENTE SIQUEIRA & $\mathrm{R} \$ 8.0$ & 0.05 & & 0.05 \\
\hline CENOURA & HEITOR SOUZA & $\mathrm{R} \$ 8.0$ & 0.1 & 0.2 & \\
\hline EMBALAGEM VIAGEM & FORNECEDOR & $\mathrm{R} \$ 0.9$ & 1 & 2 & 2 \\
\hline SACOLA KRAFT & FORNECEDOR & R\$0.2 & I & 1 & I \\
\hline
\end{tabular}

PORÇŌES UNITÁRIAS

CUSTO TOTAL

PREÇO VENDA LOCAL

PREÇO VENDA DELIVERY

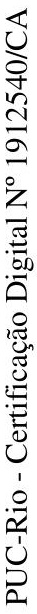

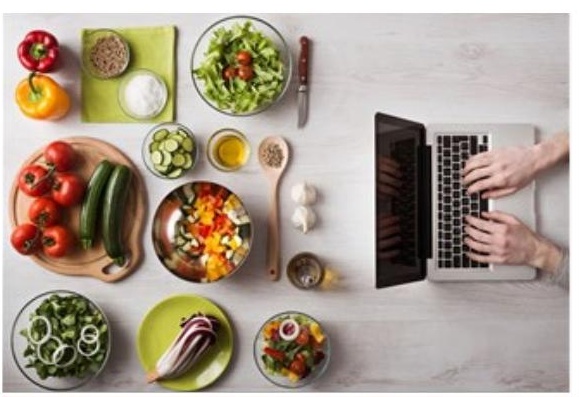

6. Elaboração de cardápio fixo

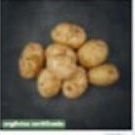

둔

$-\quad$ -
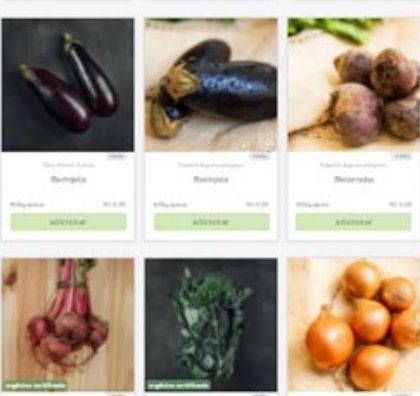

7. Controle de estoque e pedido de insumos
5. Precificação, fichas técnicas Embalagens

\begin{tabular}{c|c|c|}
\hline & 1 & 1 \\
\hline$\$ 22.30$ & $\$ 24.63$ & $\$ 16.45$ \\
$\$ 63.00$ & $\$ 68.00$ & $\$ 48.00$ \\
$\$ 69.00$ & $\$ 72.00$ & $\$ 53.00$ \\
\hline
\end{tabular}
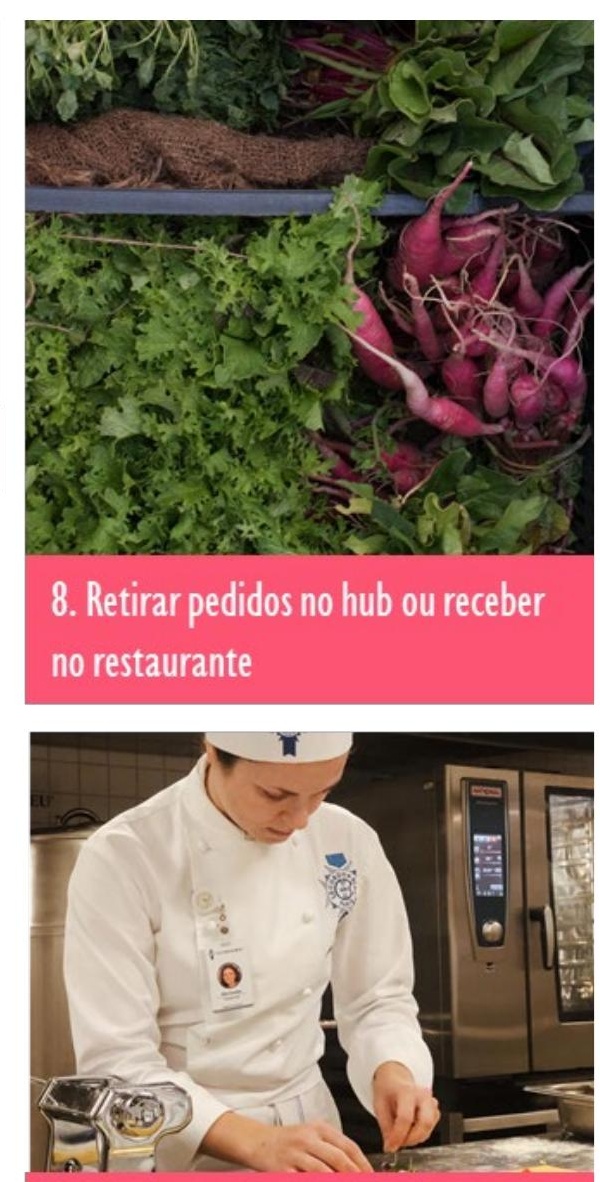

9. Elaborar menu semanal com base no que recebeu, adequar cardápio 

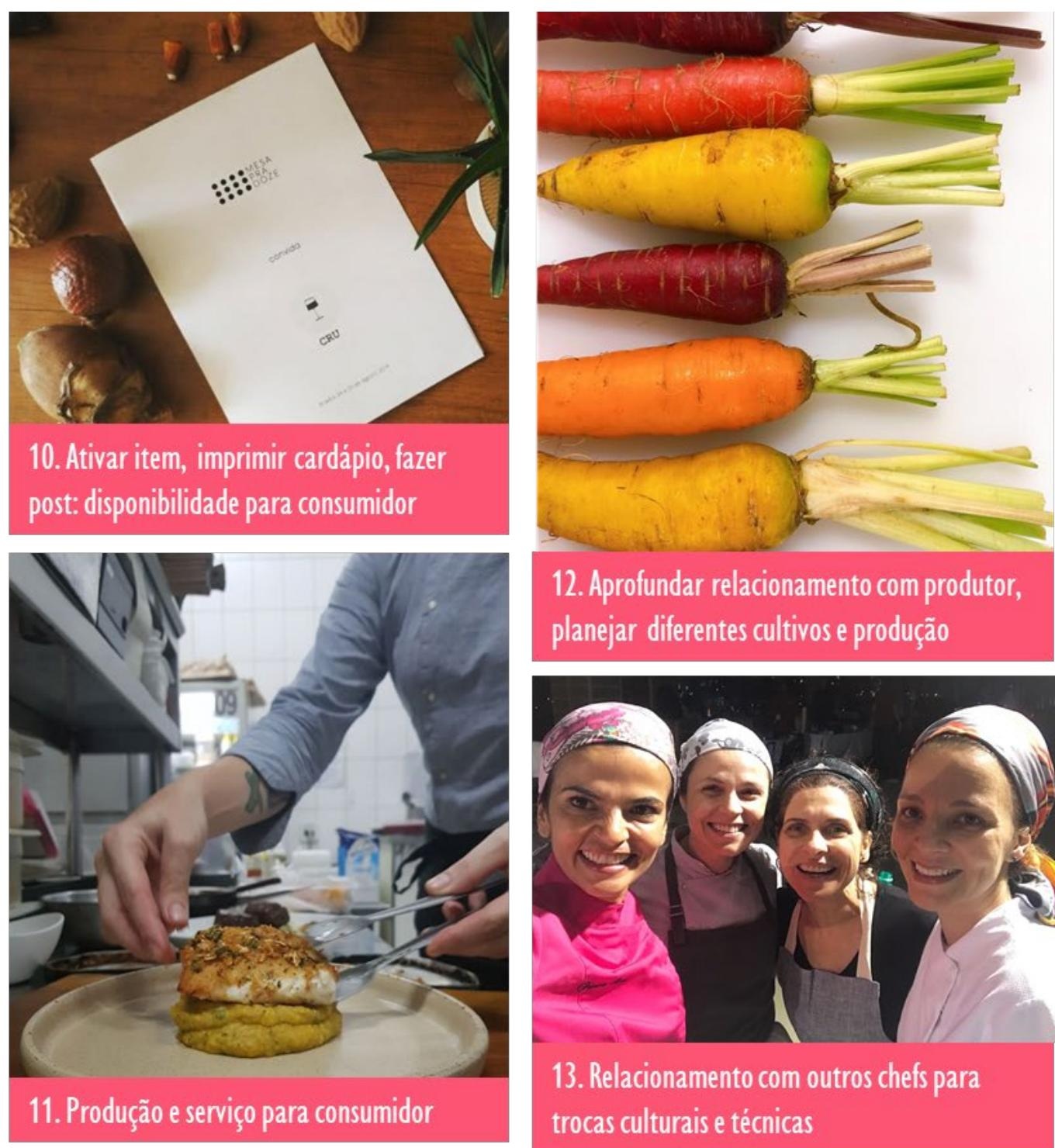

12. Aprofundar relacionamento com produtor, planejar diferentes cultivos e produção
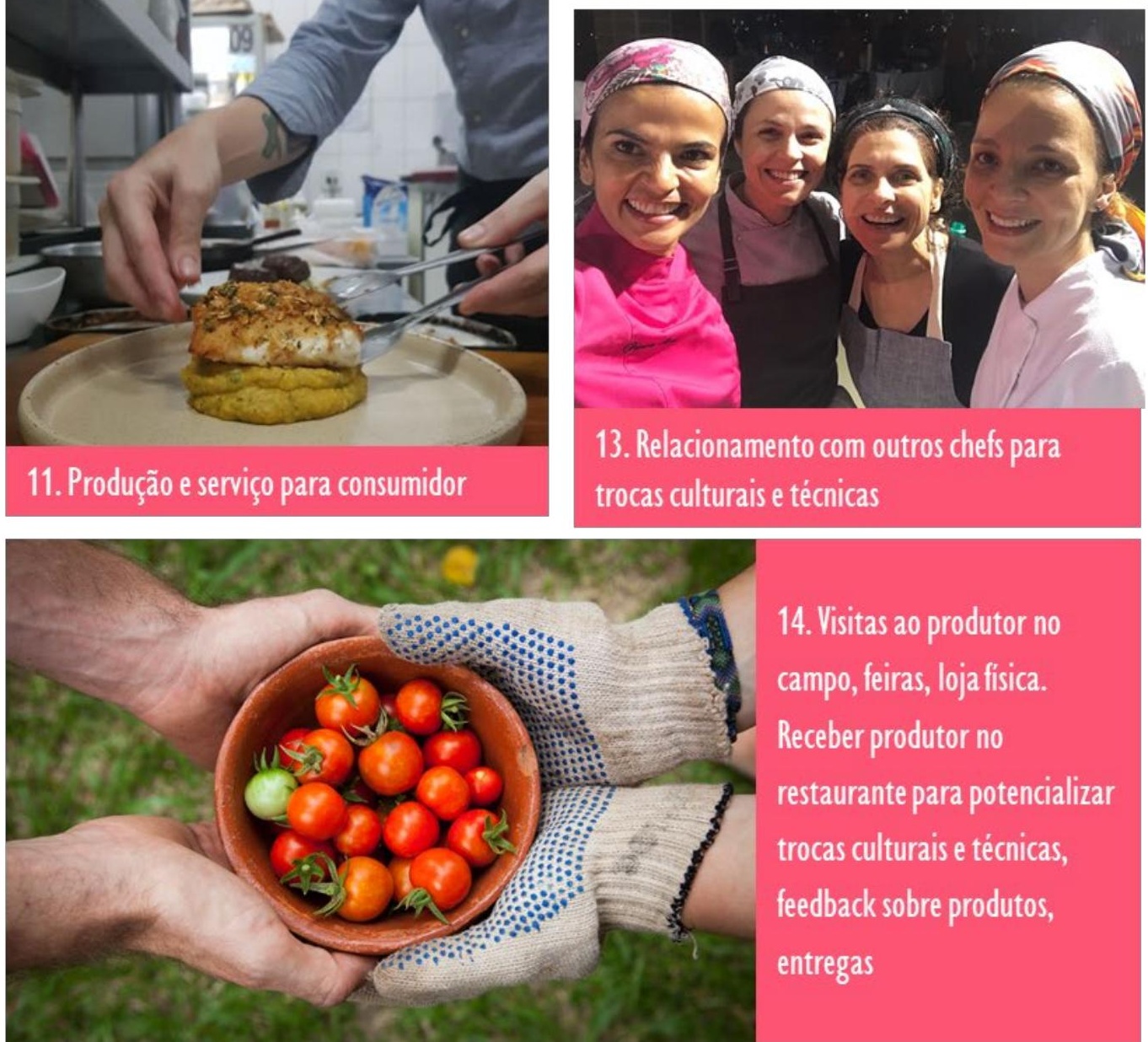

Figura 48 . Storyboard chef 

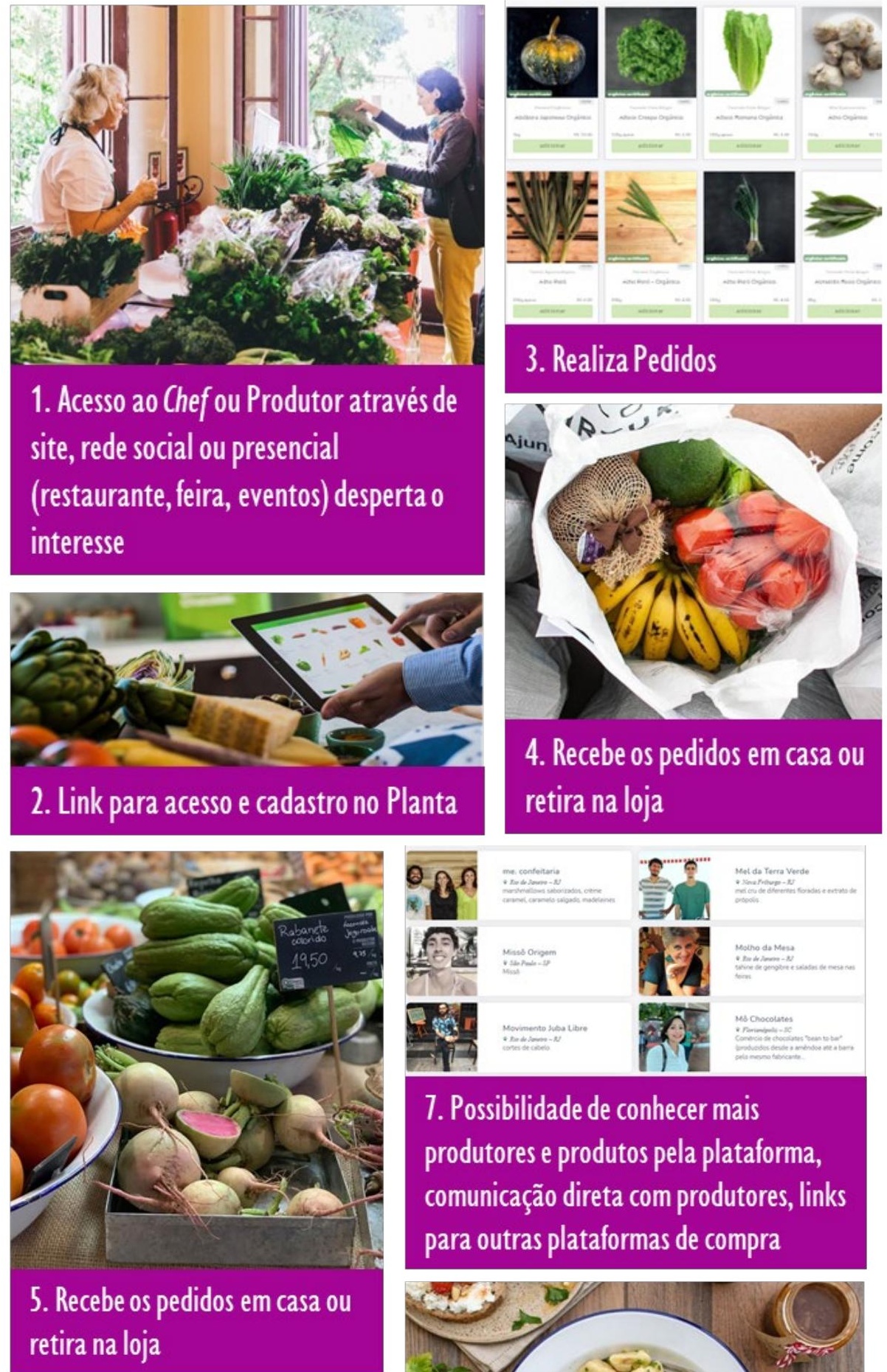

7. Possibilidade de conhecer mais produtores e produtos pela plataforma, comunicação direta com produtores, links para outras plataformas de compra

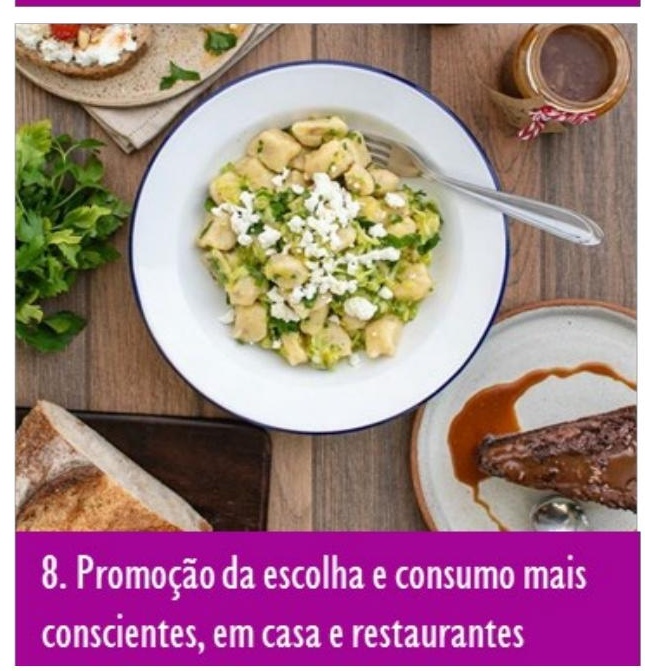

Figura 49. Storyboard consumidor 
A fim de melhor ilustrar o funcionamento da ferramenta Planta, foram feitas algumas simulações, no formato mobile, contemplando as interações entre usuários e aplicativo. Além das telas de apresentação com conteúdo de base, a simulação mostra telas para os diferentes atores abordados no projeto.

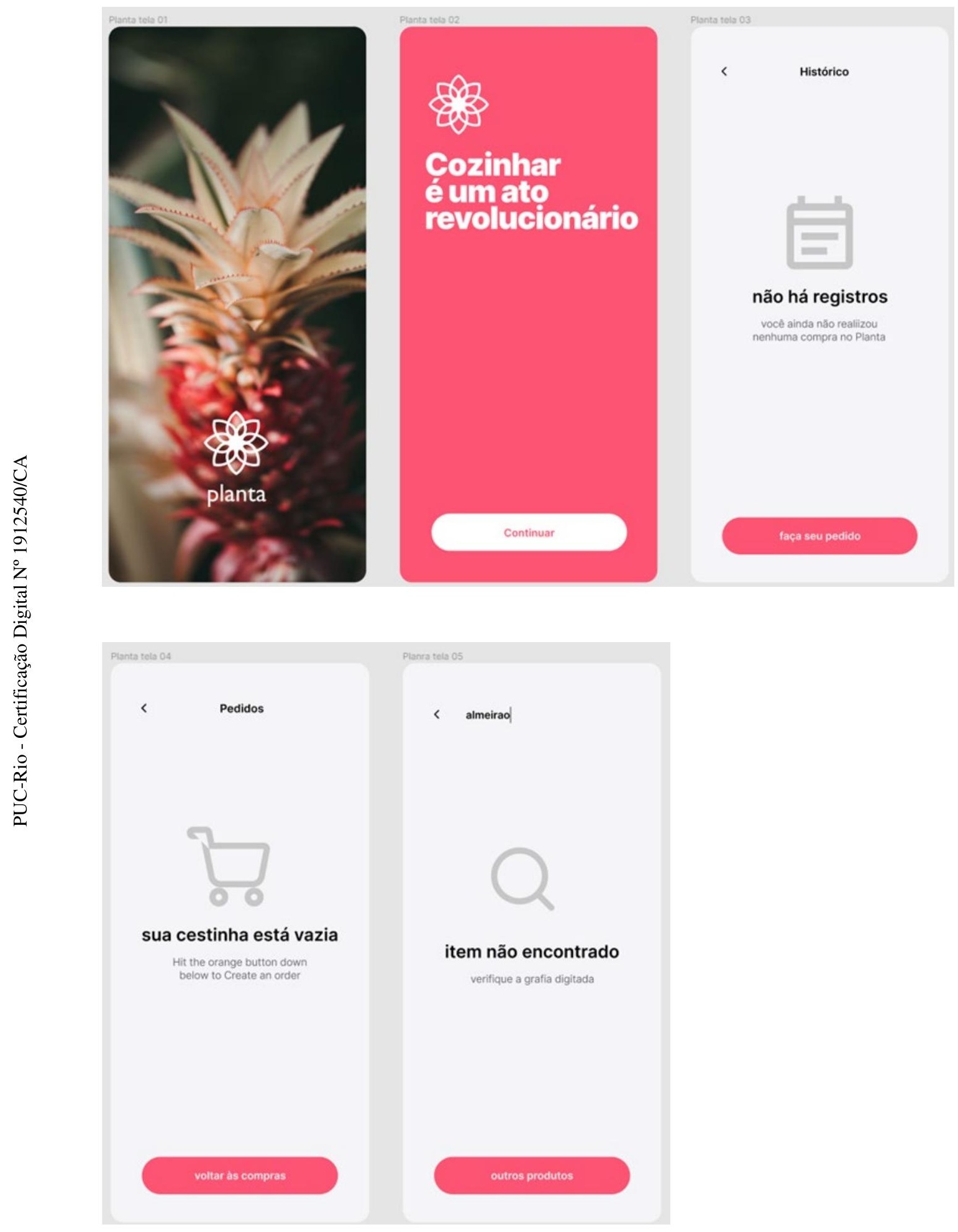

Figura 50 . Planta, aplicativo mobile 


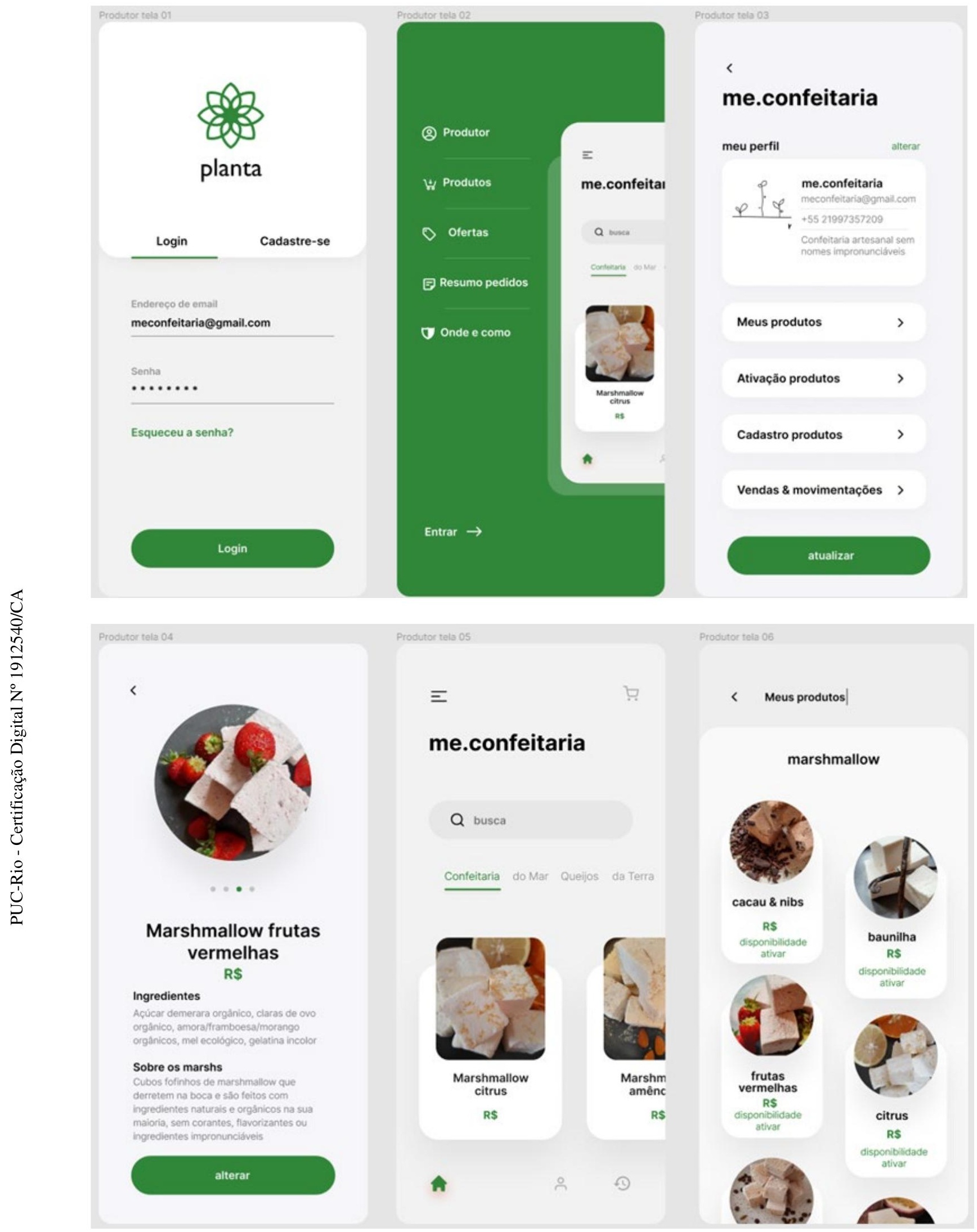




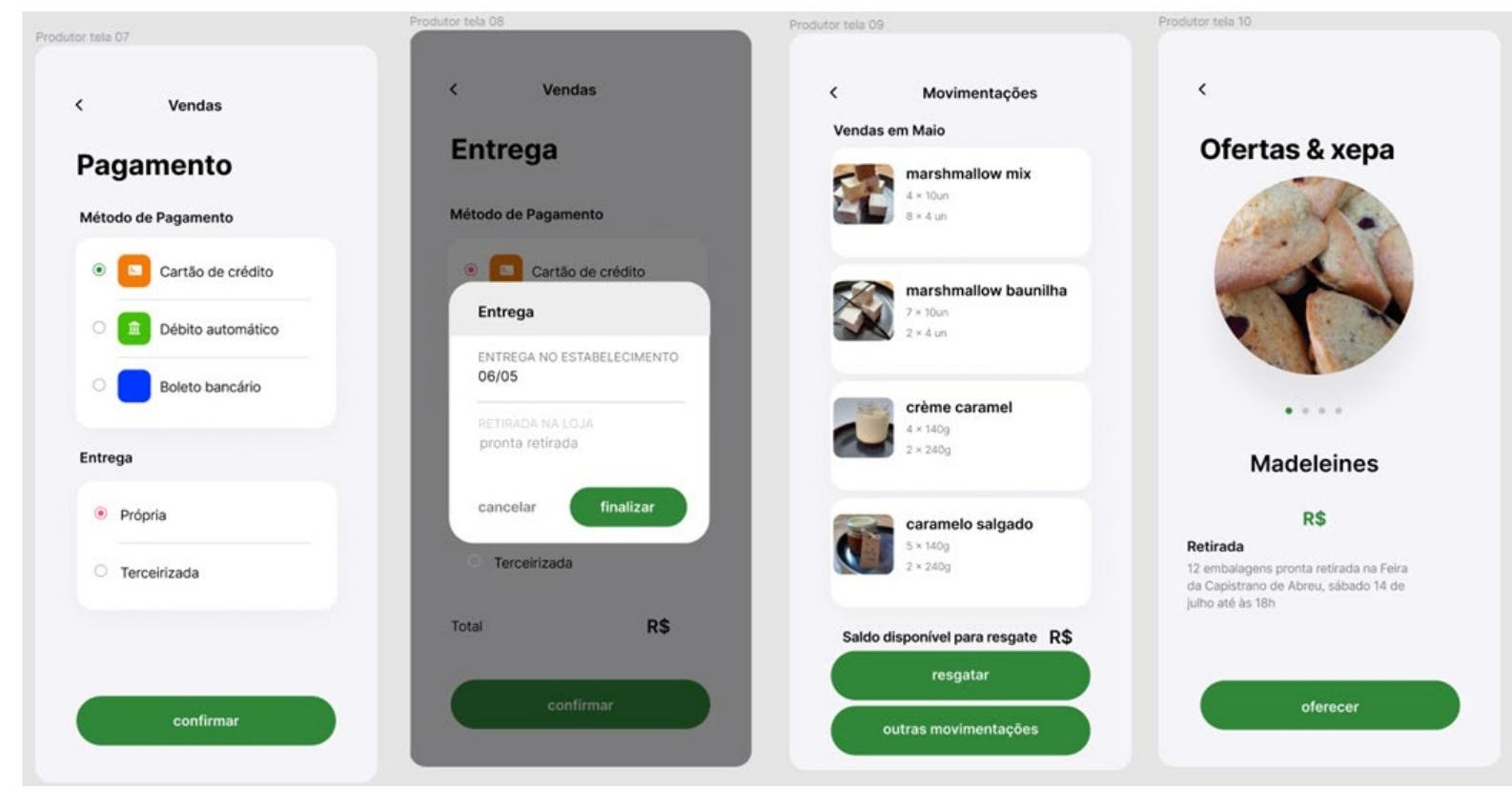

Figura 51 . Planta, aplicativo mobile Produtor

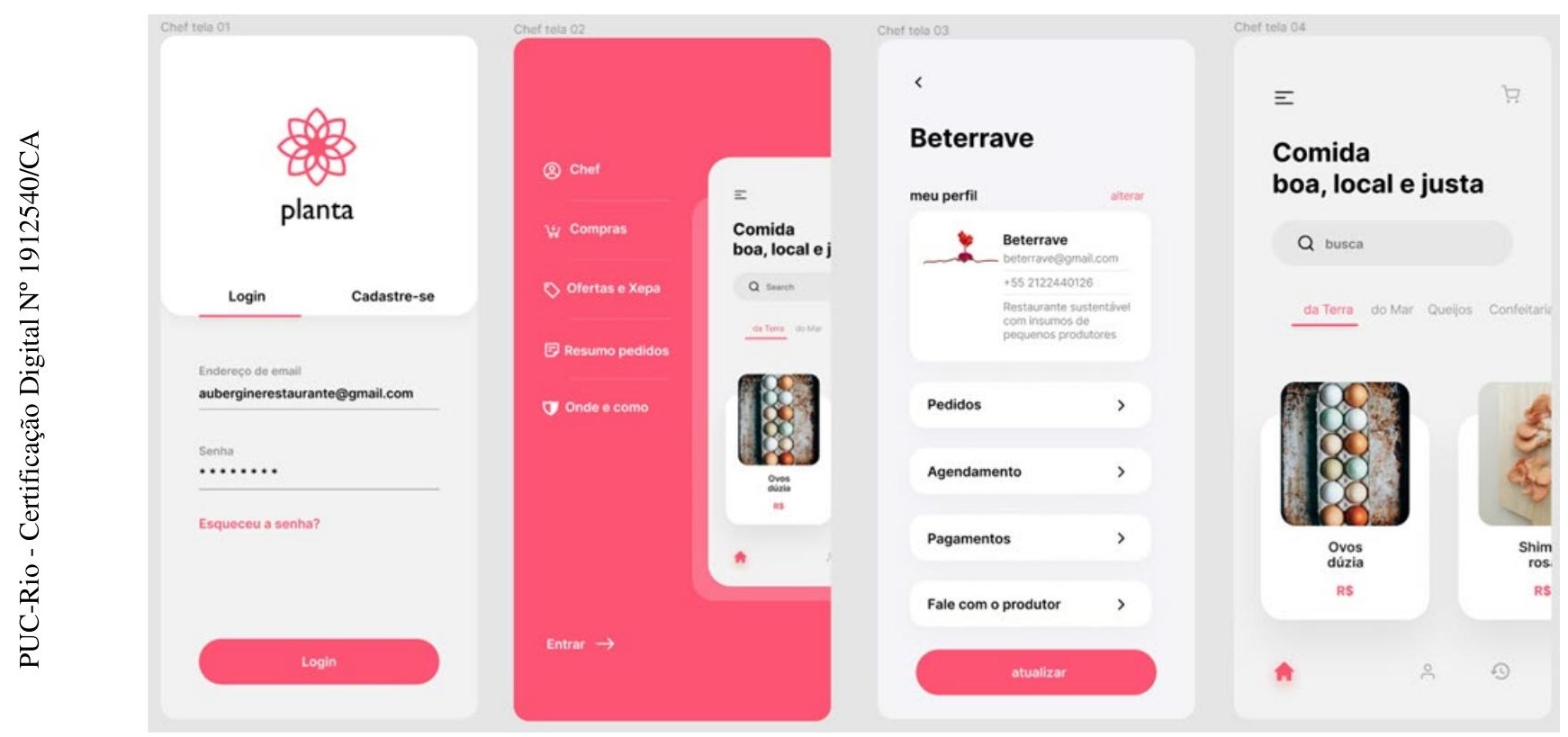




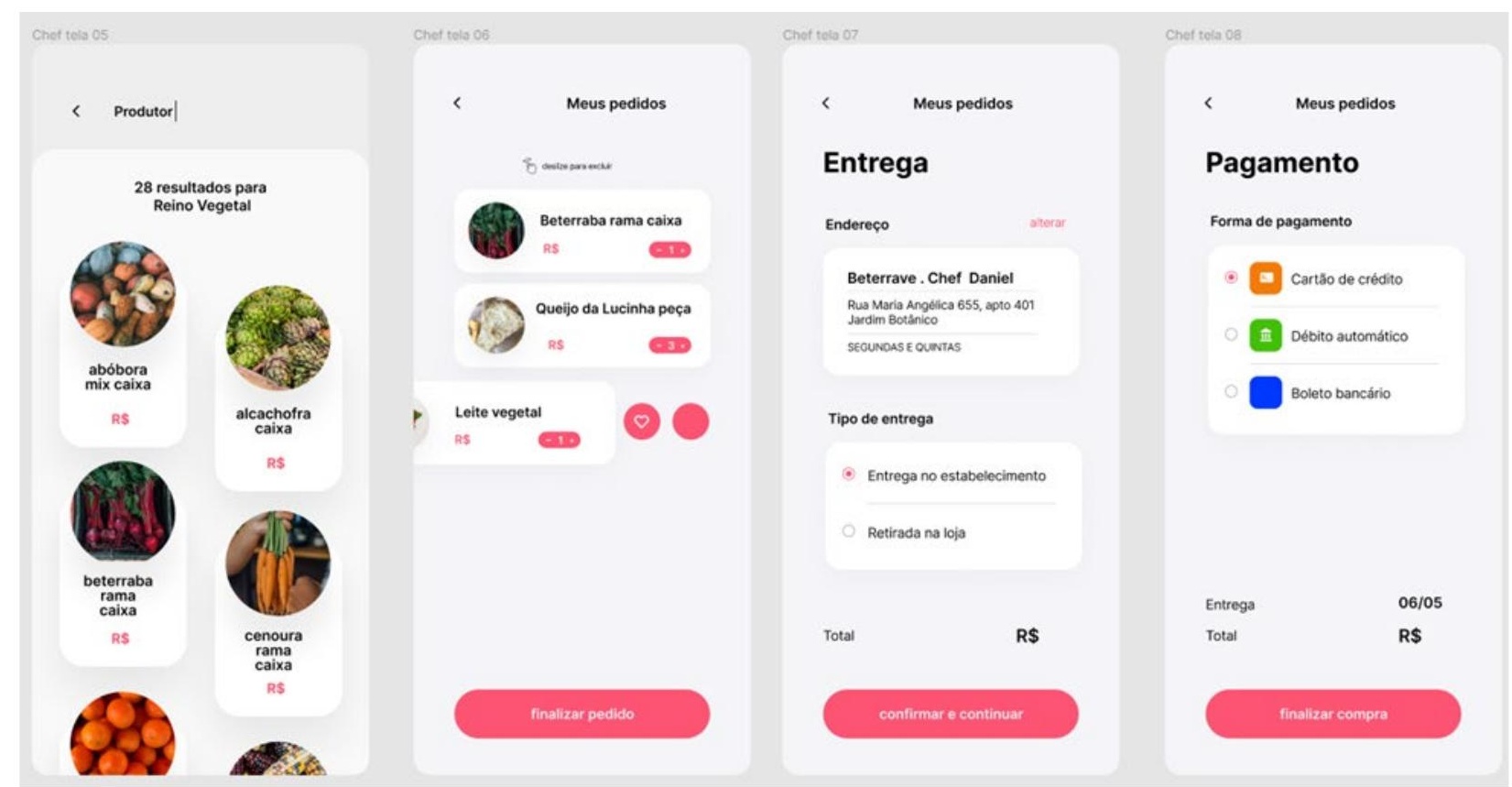

Figura 52 . Planta, aplicativo mobile Chef

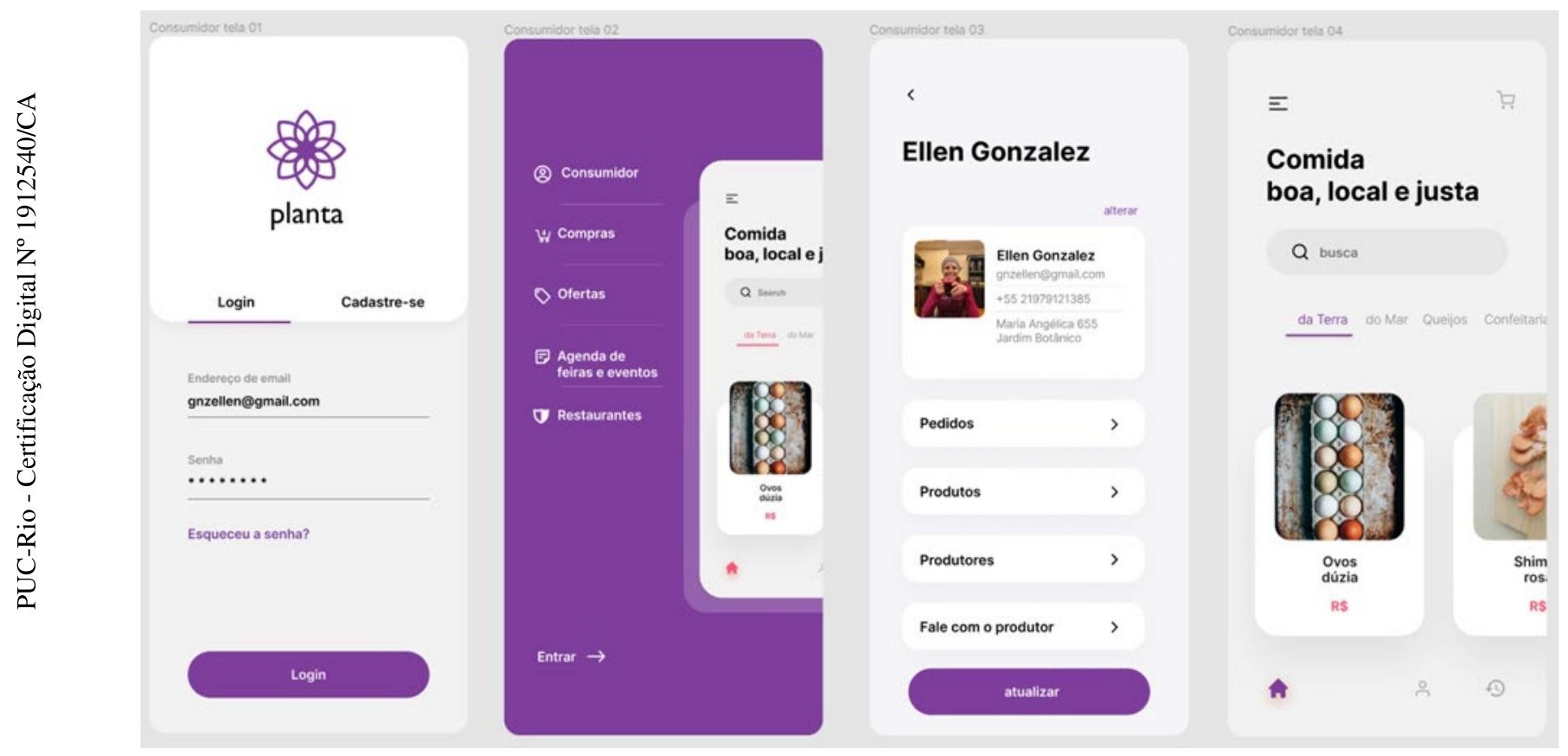




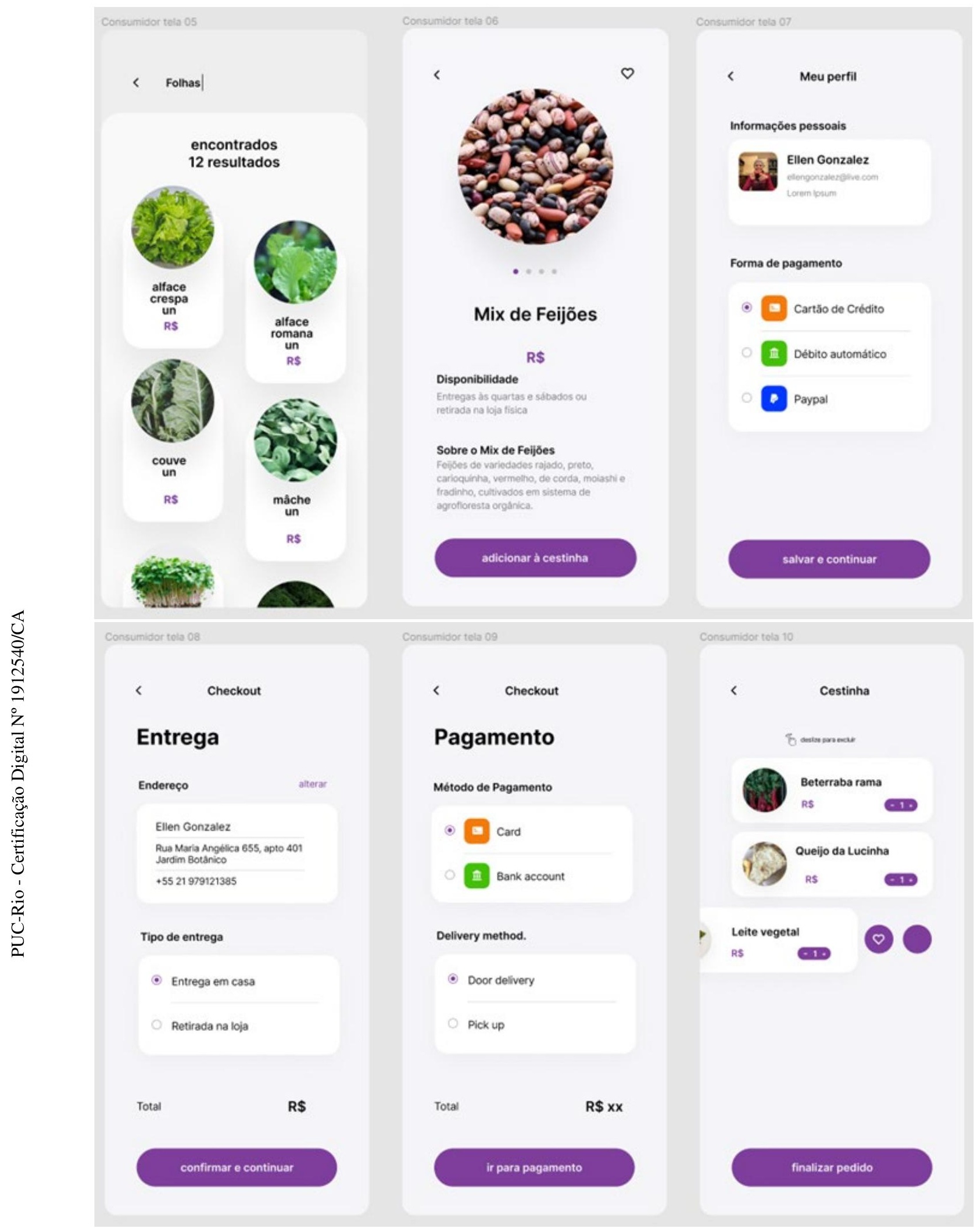

Figura 53 . Planta, aplicativo mobile Consumidor 


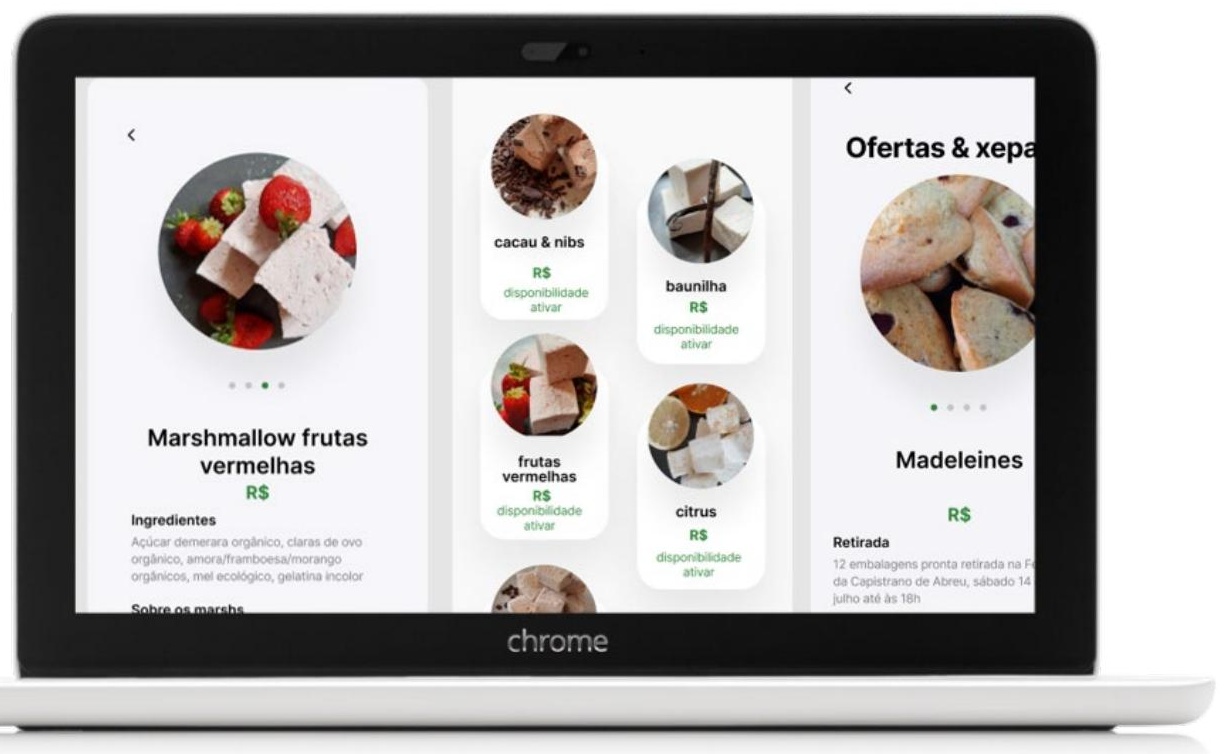

Figura 54. Plataforma versão web

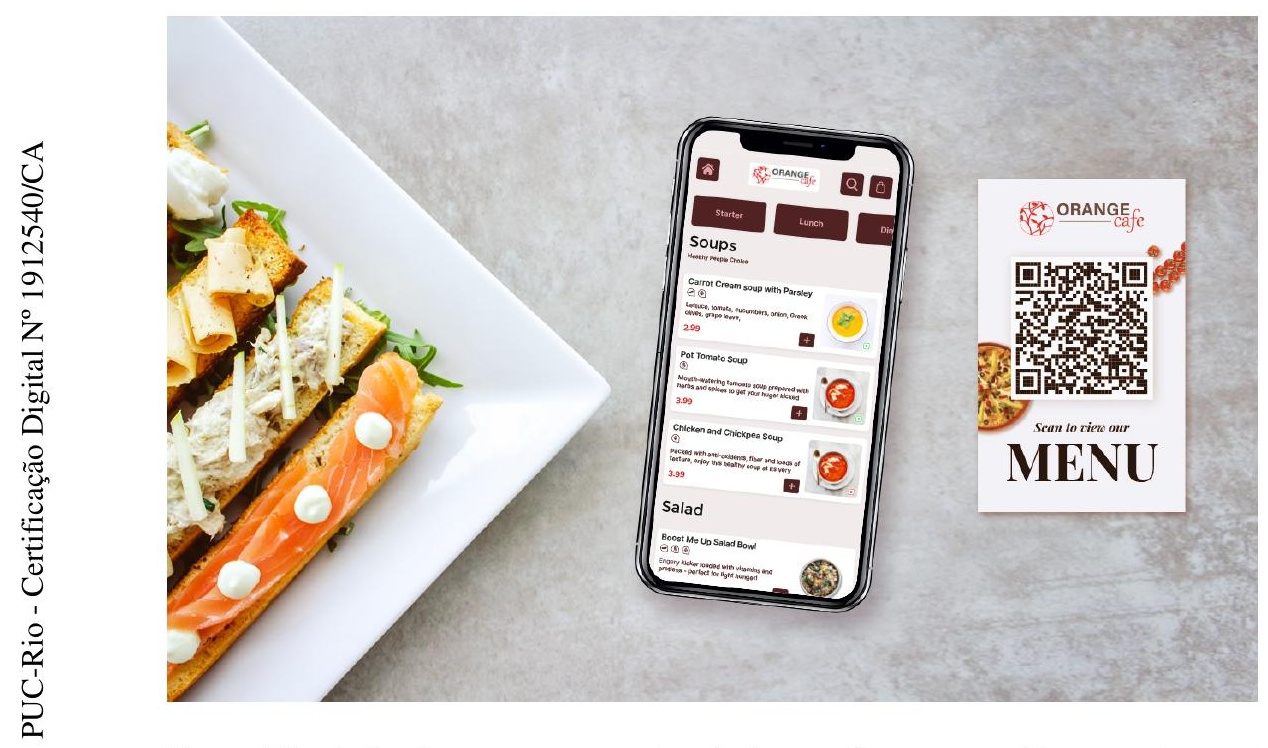

Figura 55. Aplicativo em momentos de interação: consumidor e restaurante.

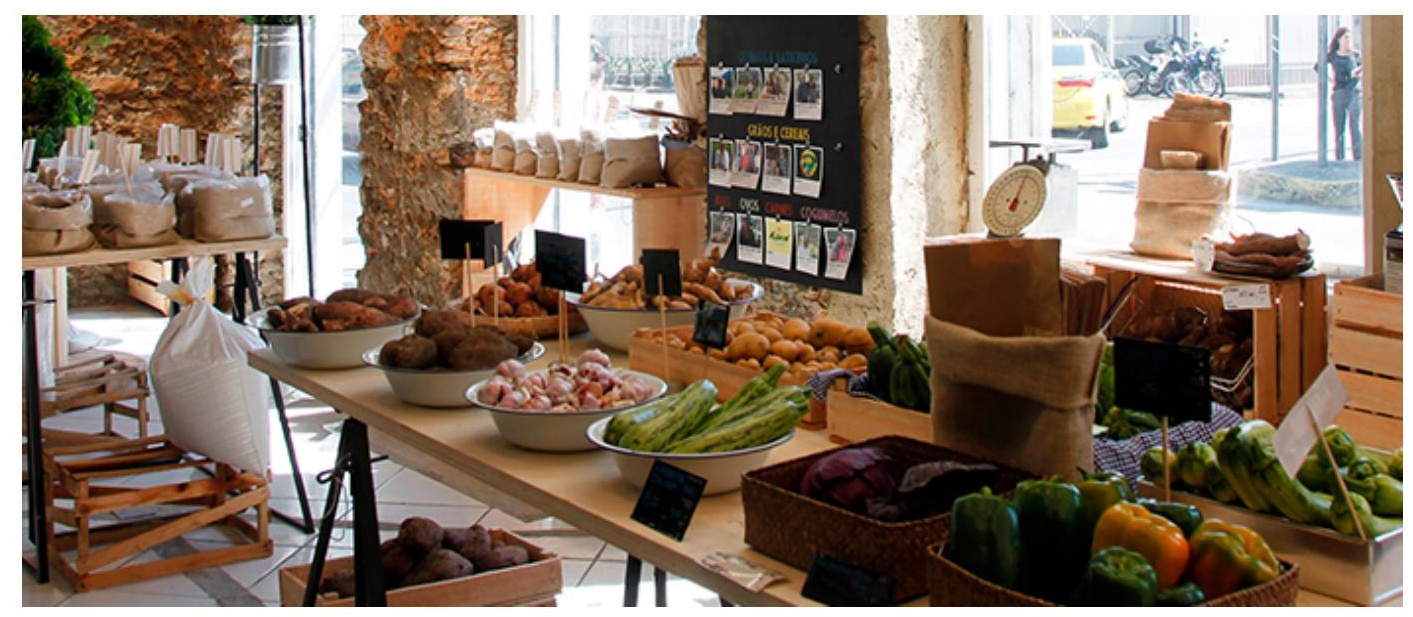

Figura 56 . Modelo de entreposto. Fonte: A Colheita. 


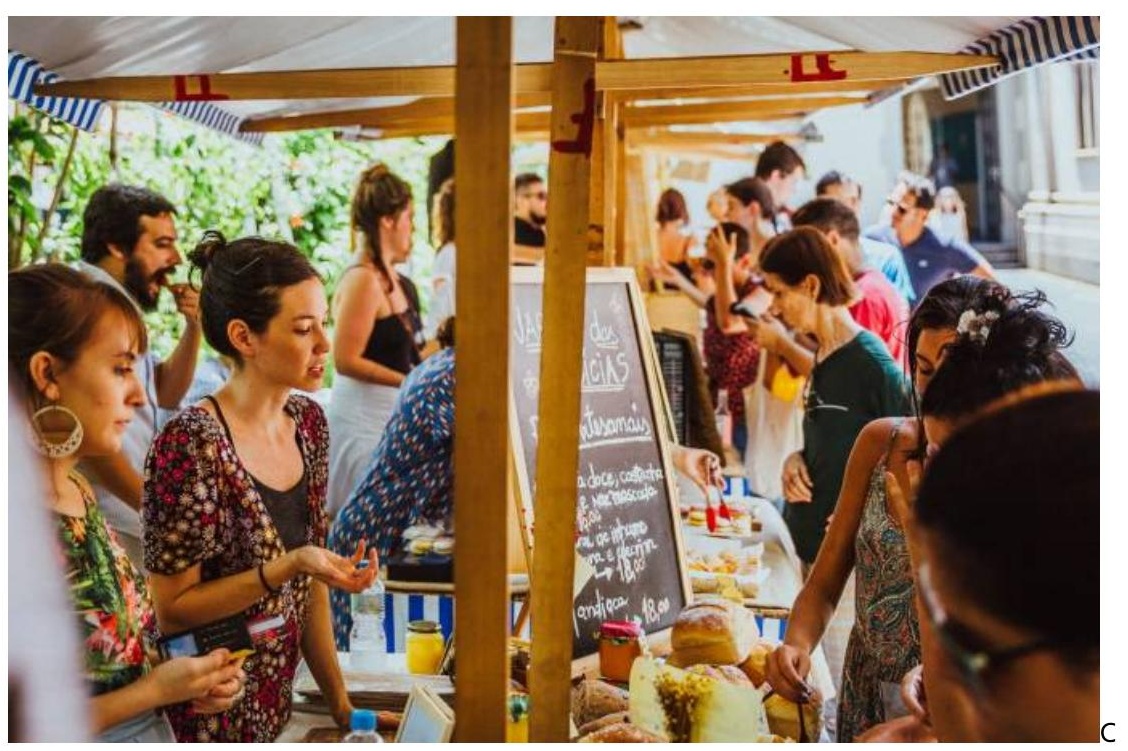

Figura 55 . Feira de pequenos produtores. Fonte: Samuel Antonini

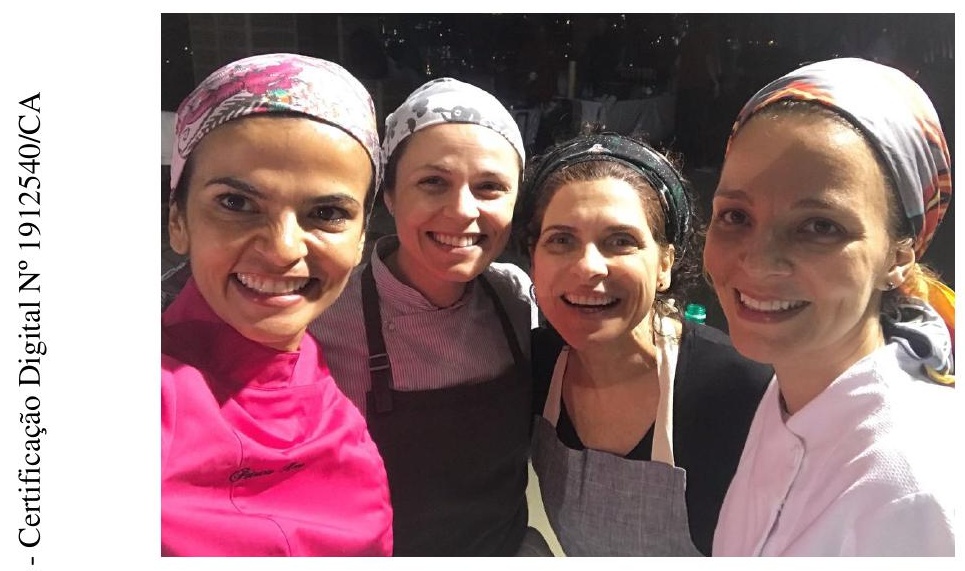

Figura 56 . Rede de contato de chefs. 
No decorrer da pesquisa, o tema foi apresentado em dois eventos de relevância do cenário do Food Design e do Design Sustentável, promovendo o debate acerca dos dados levantados nas fases de Imersão e Análise e Síntese. Ao passo que a pesquisa avançava, a própria rede de chefs, empreendedores e produtores que contribuíram nas sessões de discussão e generativas debateram os resultados alcançados, consolidando o caminho a medida em que ele era traçado.

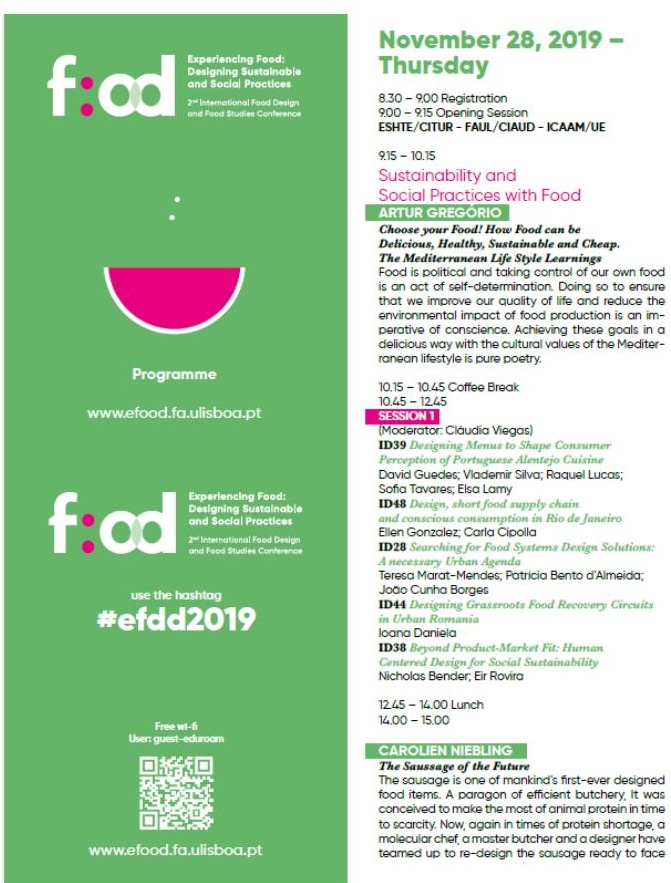

Figura 57 . EFood Lisboa 2019

\subsection{Design de Serviço e o pensamento crítico sobre a alimentação por futuros profissionais}

A disciplina Design de Serviço, ministrada pela professora Carla Cipolla para o curso de graduação em Design na UFRJ, foi estruturada com a colaboração da pesquisadora como especialista do tema proposto. Durante o primeiro semestre letivo de 2020, foi oferecido aos 16 alunos um projeto design de serviço para a alimentação. Para proporcionar maior amplitude de projetos, o exercício proposto foi a criação de um serviço voltado para chefs de cozinha em geral, com atuação profissional em qualquer setor (hotelaria, restauração, escolas, hospitais etc.); que propiciasse o encurtamento das cadeias de produção e consumo de alimentos, promovendo também o consumo consciente.

Os alunos foram sensibilizados para o tema da alimentação e cadeias de consumo pela pesquisadora; e no transcorrer do curso, além do conteúdo 
programático específico de Design de Serviço, os alunos receberam dados da fase de Imersão, compilados do conteúdo apresentados nos capítulos 5.1 Imersão Preliminar e Imersão em Profundidade e 5.2 Análise e Síntese.

Para enriquecer a fase de imersão, um dos chefs e um dos produtores entrevistados foram convidados para uma conversa em aula. A etapa de entrevista com os consumidores foi realizada pelos próprios alunos, partindo do modelo de questionário utilizado e fornecido pela pesquisadora. Com esse embasamento, coube aos discentes executarem em duplas ou trios as fases seguintes do processo de projeto; de maneira análoga às etapas e ferramentas apresentadas e utilizadas nesta dissertação.

$\mathrm{Na}$ etapa de análise e síntese, os graduandos construíram seus próprios mapas, traçando os desafios de projeto e proposição de soluções. As etapas processuais seguidas pelos alunos foram baseadas nas ferramentas anteriormente mencionadas de Design de Serviço, com exceção da fase de prototipação, devido ao curto período oferecido pelo calendário letivo.

A trajetória do curso permitiu colocar o tema da pesquisa em debate com futuros profissionais do Design, fomentar o debate sobre alimentação local, contrapor ideias e chegar a artefatos que contemplassem o desafio proposto. As discussões suscitadas enriqueceram e validaram os serviços propostos, tendo, nesse contexto, os estudantes como profissionais do Design, e a pesquisadora como especialista, chef e produtora contemplada pelo artefato

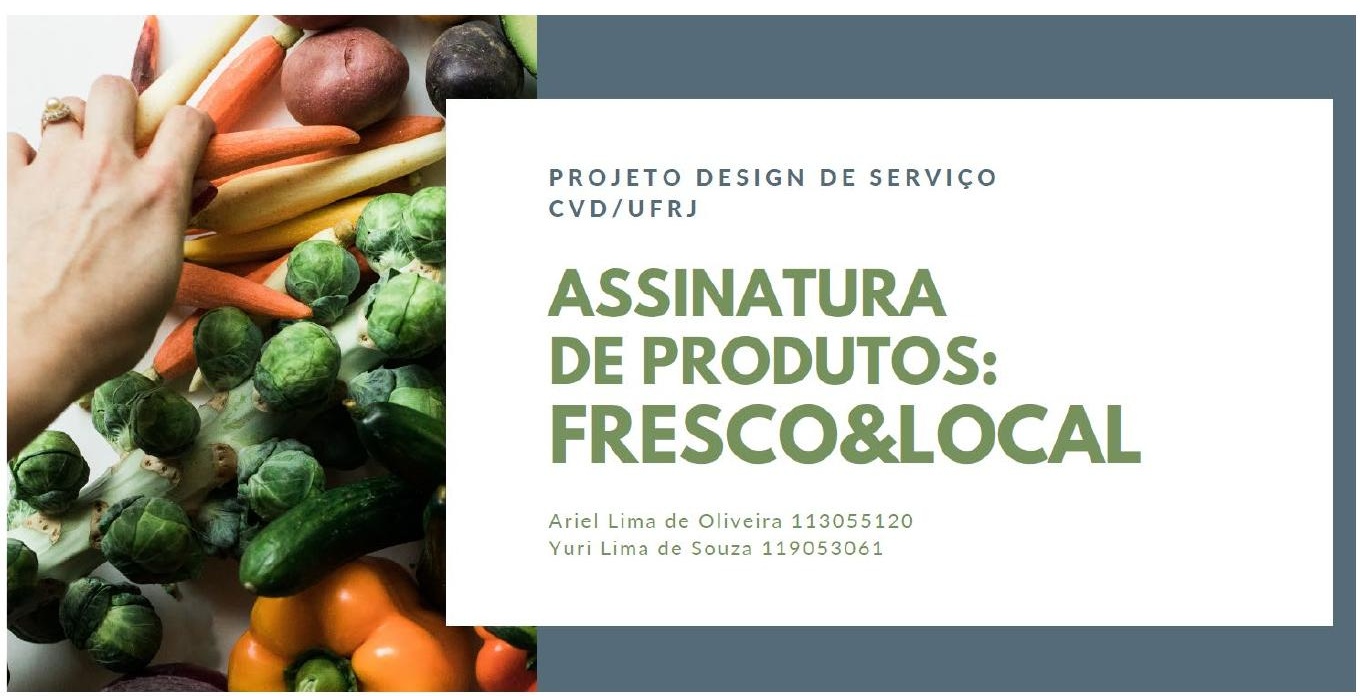

Figura 58 . Serviço desenvolvido pelos alunos de Graduação, Design, UFRJ. 


\subsection{Considerações}

Em uma apreciação final do exposto até aqui sobre a aplicação do Design em sistemas alimentares e locais, percebe-se que o papel do designer especialista "não é uma questão de fazer ou pensar, e sim do que pensar e como fazer" ${ }^{50}$ (Boyer et al., 2011, in Ballantiyne-Brodie \& Telalbasic -2017). O trabalho do designer é de se acercar dos problemas da contemporaneidade, vislumbrando questões pósteras, com soluções integradas para produtos e serviços. É trazer à luz as perturbações cotidianas e propor maneiras de saná-las, de maneira colaborativa e participativa com a sociedade, oferecendo conceitos, ferramentas, métodos e empoderando as inovações sociais.

A figura abaixo é resultante da interpretação de dois quadros comparativos propostos por Ballantyne-Brodie, em que a autora compara sua percepção sobre o papel do Design nos sistemas alimentares com o indicado por Manzini, e sugere, como maior diferencial, que a relação entre os atores e usuários sejam não só de conexão, mas de entrelaçamento, em uma visão ainda mais interdependente do relacionamento proposto - "SLOW small, local, open, woven" ${ }^{51}$ - (Ballantiyne-Brodie \& Telalbasic, 2017):

- Projetos pequenos, baseados na infraestrutura local

- Valorização da cultura, dos saberes e da ética

- Controle da escala para controle da qualidade, tanto dos produtos quanto do bem-estar dos envolvidos

- Abordagem das particularidades de cada ator

- Soluções locais para contemplar as necessidades locais

- Comunidade implementa e

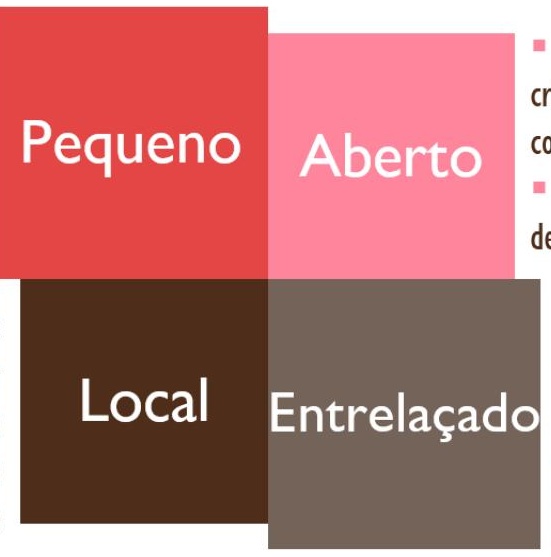

Rede de pessoas e comunidades, criando um modelo de economia aberta $\mathrm{e}$ colaborativa

- Compartilhamento de ideias através de uma rede, com abordagens locais resolve os problemas

- Manzini propõe uma conexão tecnológica, com soluções sociotécnicas

- Ballantyne-Brodie reconhece as interações e diferentes niveis de relações entre os atores dentro de uma comunidade, necessários para a construção de um sistema econômico e social locais

- Ambos sugerem que desenvolver novos modelos

- Busca e valorização das tradições locais requer engajamento, convivência, diálogo, troca de experiências, técnicas e colaboração

Figura 59. SLOW análise e adaptação das propostas de Ballantyne-Brodie (2017).

\footnotetext{
${ }^{50}$ "is not a matter of doing or thinking, it's a matter of what to think and how to do."

${ }^{51}$ pequeno, local, aberto e entrelaçado.
} 
A inserção no contexto do projeto foi crucial, assim como a troca com os usuários. Desde o início, o envolvimento com objeto de estudo e ofereceram uma oportunidade de conexão e compreensão do todo. No processo de desafio de projeto aqui apresentado, ou Desafio de Food Design, duas macro-esferas foram abarcadas:

- Da pesquisa individual: feita através de observação, interação e tempo despendido com os potenciais usuários com conversas, entrevistas, rodadas de discussões. Os produtos resultantes desse estudo foram utilizados para construir o cenário corrente, ideal, e os mapas conceituais da pesquisa.

- Da pesquisa em Design: na experimentação real e cotidiana das situações estudadas, no exercício de empatia e imersão em profundidade. O resultado desse processo ofereceu uma sólida construção de personas e definição da oportunidade de projeto.

A experiência de projetar um serviço para chefs, produtores e consumidores, com foco em tornar mais próxima e fácil essa relação comercial e pessoal, mostrou que há espaço para melhorias, como também sinalizou esforços tangíveis em direção ao uso mais sustentável das culturas alimentares. Os entrevistados mostraram-se (cons)cientes de seu papel, fazendo mudanças em suas escolhas e os efeitos que estas têm a longo prazo.

Os três atores estudados apontaram as oscilações do mercado e empecilhos financeiros como grandes barreiras a serem transpostas. Enquanto produtores e chefs precisam tentar provisionar a melhor comida, com o menor custo possível; os consumidores devem estar preparados para lidar com consequências monetárias imediatas de sua predileção por uma alimentação local. Além disso, chefs e consumidores finais podem não se mostrar receptivos a algumas mudanças, contrariados com a carência ou abundância de determinados insumos nas diferentes épocas do ano, implicando em transpor sua zona de conforto em questões cotidianas como a escolha diária do que cozinhar ou comer.

Discutir o assunto com chefs e produtores que já trabalham com cadeias curtas de produção e consumo de alimentos, e têm a consciência do impacto de suas práticas, revelou uma série de embaraços no sistema alimentar e a necessidade de melhorá-lo. Esta rede relacional, apoiada pela plataforma de divulgação, compra e entrega de alimentos pode ajudar no dia a dia. As evidências após o estudo mostram a necessidade e oportunidade de propor um sistema alimentar mais sustentável, adaptado aos desafios socioeconômicos, culturais e ambientais pautados pelos atores em questão. 
O uso dos instrumentos propostos foi discutido entre os participantes nas rodadas de webinários, que validaram as proposições. De uma maneira sólida o artefato pode os obstáculos identificados neste trabalho. No caminho para encurtar a cadeia de abastecimento alimentar, a ligação entre produtor e chef de cozinha, e do chef com consumidor final é fundamental para associar ambas as extremidades. O chef tem uma variedade de ferramentas para explorar e se tornar a conexão, mesclando campo e cidade, propagando conhecimento e criando condições para a compra e o consumo mais conscientes.

Durante o semestre letivo de trabalho na disciplina de Design de Serviço, UFRJ, pôde-se observar como o Design, enquanto metodologia de ensino e projeto, impacta, conecta e conscientiza. Os estudantes tiveram a possibilidade de projetar colaborativamente o futuro, e se envolver diretamente nas teorias e práticas de transformação social. Com o tema dos sistemas alimentares, especificamente, é nítido quanto o pensamento sistêmico, centrado no humano, típico dos profissionais de design, é capaz de se aplicar multidisciplinarmente, com visível impacto na sociedade (Massari, 2018; Vodeb, 2015; Meroni, 2007).

Trazer o tema de Food Design para alunos de graduação em Design não teve o intuito único de gerar soluções ótimas para o problema proposto, mas também de propagar conhecimento e cultura, promovendo conscientização. Nesse sentido, o exercício proposto na disciplina de Design de Serviço tratou mais uma vez de colocar o consumidor final no espectro, dessa vez pela educação. Abarcar o tema da comida em um curso de Design permitiu aos alunos o contato com uma vasta área de conhecimento, e as possibilidades de interagir com as necessidades deste grupo de estudo em particular, e todas as esferas a ele relacionadas. O tema da alimentação traz consigo uma profusão de questões e responsabilidades socioambientais, políticas, econômicas, e oferece uma gama de possibilidades de inovação.

As propostas dos alunos endossaram, também, o Desafio de Food Design idealizado e apresentado no capítulo 5, dando suporte ao trabalho da pesquisadora como designer de serviços para a alimentação. 


\section{Uma reflexão sobre Comer, Design e o Food Design}

A referência conceitual adotada nesta pesquisa sobrepõe os enquadramentos teóricos delimitados anteriormente, tanto pelo Design quanto pela Sociologia, e propõe a expressão em português "Design do Comer", em substituição ao Food Design e Eating Design para tratar das questões pertinentes aos campos do Design que têm como objeto a alimentação. Entre todas as possibilidades de ocupar-se desse objeto, o foco desse trabalho recaiu sobre sustentabilidade, sistemas e serviços alimentares, e as relações entre os atores deste complexo conjunto.

O termo Design do Comer se mostrou incipiente desde a fase de imersão, com base nas leituras e discussões da Sociologia do Consumo e da Alimentação, que a partir da década de 1960 passou a dar mais atenção ao estudo do comer como fato social total, e pouco a pouco especializou seus estudos, separando a produção rural e consumo dos alimentos, bem como as práticas relacionadas ao comer (Poulain, 2013; Schubert, 2019). Nas últimas décadas houve um novo direcionamento da abordagem sobre esse mote, dando origem à terminologia da Sociologia do Comer (Schubert 2017, Warde, 2016, Tonin, 2019).

Sob essa ótica, Design do Comer se estende da produção ao descarte de alimentos, por quem e para quem é feito, de que maneira, e enxerga o design do sistema alimentar como algo capaz de trazer inovação, transformando as relações sociais, ambientais e econômicas. Design do Comer pode ser visto como um eixo transversal de sistemas e relações entre usuários, que vai do campo à mesa, e tangibiliza processos, planejamento, tecnologias, padrões, atributos físicos, conceituais, sensoriais, éticos e estéticos da comida e do ato de comer.

Não se trata de pretender definir Design do Comer como um tema macro, mais ou menos abrangente, ele é antes um campo do Design que toca, em diferentes níveis, em aspectos relacionados ao comer; seja como metodologia de trabalho como Design Thinking, de Serviço, Sistêmico, Relacional; seja como metodologia de pesquisa; seja como uma atividade acadêmica de ensino do Design. 


\section{Conclusão}

O tema da comida/alimentação foi abordado pelo Design de maneiras diversas ao longo da história, variando em grandeza e aproximação com o tema. Como visto ao longo da pesquisa apresentada, a comida pode ser tanto o material com que se projeta, quanto o material para qual se projeta. Afora esses dois caminhos, outras trajetórias surgem, em paralelo ou interseccionando-se, dando forma à diferentes abordagens e escalas. Um número crescente de projetos de design aborda o tema com visões de sustentabilidade, empatia, co-design, design colaborativo; e projetos relacionados a alimentação mostram-se cada vez mais relevantes. Ao suscitar discussões, propor parâmetros éticos e estéticos, e idealizar sistemas e relações, o Design se coloca como forte ator de inovação social.

Pensar em um sistema alimentar de comida boa, limpa e justa, tríade sempre evocada pelo Slow Food, é uma resposta elementar a tantas questões levantadas ao longo da pesquisa, com grande contribuição dada pelo processo de imersão nos cenários dos produtores, cozinheiros e consumidores, com um entendimento das tradições de cultivo e consumo alimentares, as percepções identitárias, sensoriais e de sentimentos envolvidos na alimentação, os valores por trás dos conceitos de ética e justiça na comercialização, preparo e consumo da comida. Analisar, rever, questionar, e mudar o curso do sistema alimentar, da conscientização do poder da escolha, do impacto individual e coletivo do consumo podem acarretar verdadeiras mudanças.

Entretanto, ainda há projetos desligados dessa questão, que atendem as demandas dos grandes mercados, com foco na produção em massa, barateamento e acessibilidade dos produtos, sem necessariamente levar em conta questões éticas como manejo de resíduos, desperdício, usabilidade, qualidade.

Ao aproximar princípios e prática de design e cozinha, essa pesquisa conseguiu vislumbrar as ambições e frustrações de três pilares fundamentais da cadeia de produção e consumo de alimentos, e as conexões entre esses atores. O presente trabalho contribui para o campo teórico do Design ao levantar um arcabouço bibliográfico de relevância no tema, citados pelas áreas de Design, Sociologia e Alimentação. O material de referência que olha para esse ator central, o chef é ainda muito escasso, salientando a distância entre pesquisa e prática profissional. A literatura cunhada sobre o assunto mostra como claramente as disciplinas se ocuparam em estudar as questões relativas ao produtor e ao consumidor de alimentos, preterindo os processos intermediários e os subprodutos 
dessa relação. É relevante, portando, colocar o foco do estudo no cozinheiro, importante elo da cadeia, trazido para essa investigação pelo olhar privilegiado da pesquisadora como chef de cozinha.

Sob o viés projetual, o exercício parte de um ponto de vista de imersão total, possibilitando compreender as necessidades do sistema e propor um conjunto de soluções de maneira empática. Após a série de dinâmicas de exploração e aprofundamento no tema com cozinheiros e produtores, e posteriormente com consumidores, assomaram-se as experiências com futuros profissionais do Design, dando respaldo técnico ao projeto concebido e apresentado.

A aplicação da metodologia escolhida permitiu à pesquisa oferecer uma contribuição para o estado da arte do Food Design, do Design Thinking e de Serviço para Alimentação, partindo da investigação de uma realidade específica para um conceito generalizável. Após observar e entender o sistema alimentar, foi desenhado um serviço para promover o encurtamento da cadeia de produção e consumo, tendo como protagonista o chef de cozinha. Esse exercício mostrou como, através do Design, pode-se compreender e ressignificar as relações entre produtores, cozinheiros e consumidores, modificando as relações socioculturais, de valor e de apreço entre os atores. 
"[...] Dou respeito às coisas desimportantes e aos seres desimportantes. Prezo insetos mais que aviões. Prezo a velocidade das tartarugas mais que a dos mísseis. Tenho em mim um atraso de nascença. Eu fui aparelhado para gostar de passarinhos. Tenho abundância de ser feliz por isso. Meu quintal é maior do que o mundo. Sou um apanhador de desperdícios: Amo os restos como as boas moscas [...]"

(Manoel de Barros, 2006). 


\section{Referências Bibliográficas}

Altoé, I., \& Azevedo, E. de. Entre ingredientes, cozinhas e afetos: aspectos socioculturais de uma vida dedicada à comida. Revista Ingesta, 2(1), 251-273. 2020. van Aken, Joan. Management Research as a Design Science: Articulating the Research. Productsof Mode 2 Knowledge Production. 2021

Araium, Erica. Diálogos comestíveis. www.dialogoscomestiveis.com.br /blog. 2020

Arruda, A. J. Design e Inovação Social. São Paulo, Edgard Blücher. 2017.

Azevedo, E. de. Alimentação, sociedade e cultura: Temas contemporâneos. Sociologias, v. 19, n. 44, p. 276-307, 2017. DOI 10.1590/15174522-019004412.

Azevedo, E. de. $\mathrm{O}$ ativismo alimentar na perspectiva do locavorismo. Ambiente

\& Sociedade, v. 18, n. 3, p. 81-98, 2015. DOI 10.1590/18094422asoc740v1832015.

Ballantyne-Brodie, E.; Ramsey, R. et al. Design led innovation to rejuvenate local food systems and healthy communities: An emerging research agenda. 323-330. 0.1109/TIDMS.2013.6981254. 2013.

Ballantyne-Brodie, E., Wrigley, C.; Ramsey, R. Evolution of the Docklands Food Hub: A Design-Led Innovation Approach to Food Sovereignty Through Local Food Systems', Journal of Design, Business \& Society 1: 1. 2015.

Ballantyne-Brodie, E.; Telalbasic, Ida. Designing local food systems in everyday life through service design strategies. The Design Journal, 20:sup1, S3079-S3095. 2017

Barber, Dan. The third plate. Penguin Books, 2015.

Barber, Dan. Chef's Table. Temporada 1, Episódio 2, Netflix. 2015

Barbosa, L. A ética e a estética da alimentação contemporânea. In: CRUZ, F. T. da;

Barbosa, L. Tendências da alimentação contemporânea. In: Pinto, M. L.; Pacheco, J. K (org.). Juventude, consumo e educação. Porto Alegre: ESPM, p. 1561. 2009.

Barros, Manoel de. O apanhador de desperdícios. In. PINTO, Manuel da Costa. Antologia comentada da poesia brasileira do século 21. São Paulo: Publifolha, 2006. p. 73-74.

Baskerville, R; Wood-Harper, A. T. A Critical Perspective on Action Research as a Method for Information Systems Research. Journal of Information Technology, $v$. 11, n. 3, p. 235-246. 1996.

Baskerville, R. Investigating information systems with action research, Communications of the Association for Information Systems, v. 2, artigo 19, 1999.

Baskerville, R; Myers, M. D. Special Issue on Action Research in Information Systems: Making IS Research Relevant to Practice - Foreword. MIS Quarterly, v. 28, n. 3, p. 329-335. 2004.

Benjamin E.Graeub et al. The State of Family Farms in the World. Elsevier. 2016. Experiencing Food, Designing Dialogues

Bonacho, R., et al. Proceedings of the 1st International Conference on Food Design and Food Studies (EFOOD 2017), Lisbon, Portugal. 2018.

Bonacho, R., et al. Proceedings of the 2st International Conference on Food Design and Food Studies (EFOOD 2019), Lisbon, Portugal, 2020.

Bonsiepe, Gui. Design, Cultura e Sociedade. Editora Blucher, 2011

Bonsiepe, Gui. Do Material ao digital. Editora Blucher, 2015.

Bonsiepe, Gui. Atec Cultural, palestra. 2018. www.atec.com.br/blog/

sustentabilidade/design-e-a-crise-gui-bonsiepe. Acesso em outubro, 2019 
Borges, C.D.; Santos, M.A. Aplicações metodológicas da técnica de grupo focal: fundamentos metodológicos, potencialidades e limites. Rev. SPAGESP, v.6, n.1. 2005.

Bourdieu, Pierre. A distinção: Critica social do julgamento. São Paulo: Edusp; Porto Alegre: Zouk. 2008.

Brasil. Ministério da Saúde. Guia alimentar para a população brasileira. Secretaria de Atenção à Saúde, Departamento de Atenção Básica. - 2. ed., 1. Reimpressão. Brasília, 2014.

Brito, Bruna Ramires. Relações entre design e gastronomia no cenário contemporâneo. Orientadora: Mônica Cristina de Moura Dissertação (Mestrado)Universidade Estadual Paulista. Faculdade de Arquitetura, Artes e Comunicação, Bauru, 2018

Brown, Tim. Design Thinking. Harvard Business Review América Latina, Alta Books, 2008.

Brown, Tim. Change by Design. Harper Business, Nova lorque, 2009

Brown, Tim; Wyatt, J. Design Thinking for social innovation. Stanford Social Innovation Review, 8(1), 31-35, 2010.

Buber, M. Between Man and Man. Routledge Classics, Reino Unido, 2002.

Buchanan, R. Wicked Problems in Design Thinking. Design Issues, Vol. 8, No. 2, pp. 5-21, The MIT Press. 1992. www.jstor.org/stable/1511637. Acesso em agosto, 2018.

Buchanan, R. Management and Design: Interaction Pathways in Organizational Life, in Managing as Designing. Stanford, Stanford University Press. 2004.

Buchanan, R. Wicked Problems in Design Thinking. Design Issues, Vol. 8, No. 2, pp. 5-21, The MIT Press. 1992.

Câmara Cascudo, Luís da. História da alimentação no Brasil. São Paulo, Global, 2011.

Canesqui, A. M., e Garcia, R.W.D., org. Antrolopogia e nutrição um diálogo possível. Rio de Janeiro, Ed Fio Cruz, 2005

Cassol, A.; Schneider, S. Produção e consumo de alimentos: Novas redes e atores. Porto Alegre, Universidade Federal do Rio Grande do Sul (UFRGS), 2019.

Castro, J. de. Geografia da Fome. 5a edição ed. Rio de Janeiro: Civilização Brasileira, 2005.

Cereja, Lis. https://slowfoodbrasil.org/2020/03/apoie-a-agricultura-familiarincentive-o-comercio-local-compre-direto-do-produtor/ 2020. Acesso em julho, 2020.

Chiaradia, Bruna; Bentz, Ione M. G.; Costa, Filipe C.X. O Percurso Gerativo de Significação no Food Design: um estudo sobre os episódios da série Chef's Table. UNISINOS, 2016.

Cipolla, C. Designing for interpersonal relational qualities in services. A model for service design theory and practice (PhD thesis in Industrial Design). Milan. Politecnico di Milano University, 2007.

Cipolla, Carla. Solutions for relational services. In: Miettnen, S. (org). Service Design with Theory. Discussions on Change, Value and Methods. Rovaniemi: Lapland University Press (LUP) Publishing. 2012.

Cipolla, C.; Bartholo, R. Empathy or Inclusion: A Dialogical Approach to Socially Responsible Design. International Journal of Design, 2014. 2009.

Cipolla, C., Manzini, E. Relational Services. Knowledge and Policy. 22(1):45-50.

Climate Change, Agriculture and Food Security. www.ccafs.cgiar.org, acesso em Julho 2020.

de Clercq, Matthieu; Vats, Anshu \& Biel, Alvaro. Agriculture 4.0: The future of Farming Technology. World government Summit, 2018.

Clune, Stephen et al. Food Design for sustainability conversation cards. 2016. 
Creswell, John W. Projeto de pesquisa: métodos qualitativo, quantitativo e misto. Porto Alegre: Artmed, 2007.

Cross, Nigel. Designerly ways of knowing. Springer, 2006.

Cross, Nigel. Engineering design methods. Strategies for product design. Chichester, John Wiley \& Sons, Ltd. 2008.

Cross, N. Design Thinking. Understanding How Designers Think and Work. UK: Berg. 2011.

Deakin, Lynda. IDEO's Approach to Designing a Better Food System. Podcast: Creative Confidence Series, design for Food. Acessado em 14 de outubro de 2019.

Desmet, PMA and Hekkert P. Framework of product experience. International Journal of Design 1: 57-66. 2007.

Dumitru, A. et al. Transformative Social Innovation: Slow Food Movement. A summary of the case study report on the Slow Food Movement. TRANSIT: EU SSH.2013.3.2-1 Grant agreement no: 613169. 2016.

EAT-Lancet Commission. (https://eatforum.org/eat-lancet-commission/) Acesso em Maio, 2019.

Fernald, Anya et al. A World of Presidia: Food, Culture and Community, Slow Food Editore, 2004.

Ferreira, Isabela de Mattos; Nojima, Vera Lúcia Moreira dos Santos; Paula, Frederico Braida Rodrigues de. Design transversal e as práticas de ressignificação para a cidadania no espaço público. Rio de Janeiro, 2017. 188p. Tese de Doutorado - Departamento de Artes \& Design, Pontifícia Universidade Católica do Rio de Janeiro.

Ferrari, D. L. Cadeias Agroalimentares Curtas: a Construção Social de Mercados de Qualidade pelos Agricultores Familiares em Santa Catarina. Faculdade de Ciências Econômicas, Universidade Federal do Rio Grande do Sul, 2011.

Feagan, Robert. The place of food: Mapping out the 'local' in local food systems. Progress in Human Geography - PROG HUM GEOGR. 31. 23-42. 10.1177/0309132507073527. 2007.

Featherstone, M. Consumer Culture and Postmordernism. Londres, Sage. 1991.

Flynn, A.; Harrison, M.; Marsden, T. Consuming Interests: The Social Provision of Foods. Routledge, 2000.

Franqueira, T. Creative Places for Collaborative Cities. PhD diss., Politecnico di Milano. 2009.

Galli, F.; Brunori, G., eds. Short Food Supply Chains as drivers of sustainable development. Evidence Document. Document developed in the framework of the FP7 project FOODLINKS. Laboratorio di studi rurali Sismondi. 2013

Gazolla, M., Schneider, S. Cadeias curtas e redes agroalimentares alternativas: negócios e mercados da agricultura familiar. Porto Alegre, Editora da UFRGS, 2016.

Goodman, D. The quality 'turn' and alternative food practices: Reflections and agenda. Journal of Rural Studies, 2003.

Goodman, D., Dupuis, E. Knowing food and growing food: beyond the production-consumption debate in the sociology of agriculture. Sociologia Ruralis Volume 42, Issue 1, pp 5-22, 2002.

Goodman, D.; Dupuis, E. M.; Goodman, M. K. Alternative food networks: knowledge, practice, and politics. Abingdon: Routledge, 2012.

Groll, S., \& Hunter, K. Traces and Hopes of Design Research: An Interview with Gui Bonsiepe, Klaus Krippendorff, Siegfried Maser, and René Spitz. Design Issues, 31 (1), 18-31, 2015.

Guzatti, T. C.; Sampaio, C. A.; Turnes, V. A. Novas relações entre agricultores familiares e consumidores: perspectivas recentes no Brasil e na França. http://revista.dae.ufla.br/index. php/ora/article/view/852/453. Acesso em julho 2018.

Hardt, Michael. Design the term Design. www.michael-hardt.com acesso em março 2019. 

2005.

Heskett, John. Design, a Very Short Introduction. Nova Iorque, Oxford Press,

IDEO, The Field Guide to Human-Centered Design. Canadá, IDEO.org, 2015.

Ilbery, B.; Maye, D. Alternative (shorter) food supply chains and specialist livestock products in the Scottish/English Borders. Environment and Planning A. 37. 823-844. 10.1068/a3717, 2005

Ilbery, B.; Maye, D. Food Supply Chains and Sustainability: Evidence from Specialist Food Producers in the Scottish/English Borders. Environment and Planning, 2005.

Ilbery, B.; Kneafsey, M. Producer constructions of quality in regional speciality food production. Journal of Rural Studies, Amsterdam, v. 16, p. 217-230, 2000.

Ilbery, B. et al. Product, process and place: an examination of food marketing and labelling schemes in Europe and North America. European Urban and Regional Studies, London, v. 12, n. 2, p. 116-132, 2005.

JBF James Beard Foundation. www.jamesbeard.org/food-waste-culinaryinstructor-curriculum. Acesso em junho, 2020.

Jégou, F.; Bala, P.; Manzini, E. Collaborative Services: Social Innovation and Design for Sustainability. Poli Design, 2008.

Junta Local. www.juntalocal.com. Acesso em maio 2019, fevereiro 2020, agosto 2020. 2014

Kalback, J. Mapeamento de Experiências. Alta Books. 2017

Kazazian, T. Haverá a Idade das Coisas Leves: Design e Desenvolvimento Sustentável. Senac, 2003.

Kemmis, Stephen; McTaggart, Robin; Nixon, Rhonda. The Action Research Planner, Doing Critical Participatory Action Research. Springer Singapore Heidelberg New York Dordrecht London. e-book. 2014.

Instituto Maniva. Ecochefs. www.institutomaniva.org. 2007. Acesso em agosto 2020.

Lacerda, D. et al.. Design Science Research: método de pesquisa

para a engenharia de produção. Gest. Prod., São Carlos, v. 20, n. 4, p. 741 761,2013

Lee, Y., Breuer, C., \& Schifferstein, H. N. J. Supporting Food Design processes: Development of Food Design cards. International Journal of Design, 14(2), 51-64. http://www.ijdesign.org/index. php/IJDesign/article/view/3467/909. 2020

Lewin, M.; Martin, A. W. The praxis of educating action researchers: the possibilities and obstacles in higher education. Action Research, v. 5, n. 3, p. 219229. 2007.

Loken, Brent et al. Diets for a Better Future: Rebooting and Reimagining Healthy and Sustainable Food Systems in the G20. 2019.

Lowdermilk, Travis. User-Centered Design. O'Reilly Media, Inc. 2013.

Manzini, E. Context-based wellbeing and the concept of regenerative solution. A conceptual framework for scenario building and sustainable solutions development. The Journal of Sustainable Product Design, 2(3), 141-148. 2002.

Manzini, E. Small, local, open, and connected: design for social innovation and sustainability. The Journal of Design Strategies. 2010.

Manzini, E. Design, when everybody designs: an introduction to design for social innovation. The MIT Press, 2015.

Manzini, E. Making things happen: Social innovation and design. Design Issues, 30, 2015.

Manzini, E. Design Cultures and Dialogic Design. Design Issues: Volume 32, Number 1 Winter, 2016.

Manzini, E., Staszowski, E. Public and collaborative. Exploring the intersection of design, social innovation and Public Policy. Desis Network. 2013. 

2009

Margolin, Victor. Design in History. In: Design Issues, v. 25, n.2, p.94-105.

Margolin, V. Design Studies and Food Studies: Parallels and Intersections. Design and Culture, v. 5, n. 3, p. 375-392, 2013.

Margolin, S. Um modelo social de design: questões de prática e pesquisa. Revista Design em Foco, v. 1, n. 1, p. 43-48, 2004.

Marsden, T. Theorising food quality: some issues in understanding its competitive production and regulation. In: Harvey, M.; Mcmeekin, M.; Warde, A. (Ed.). Qualities of food. Manchester: Manchester University, 2004.

Marsden, T.; Banks, J.; Bristow, G. Food supply chain approaches: exploring their role in rural development. Sociologia Ruralis, Wageningen, v. 40, n. 4, 2000

Massari, Sonia. Designing New Tools And Service For Agro-Ecology Systems From Education To Innovation Gustolab Institute - Center For Food Studies - Rome University of Illinois Urbana Champaign - Food Studies Programs, 2018.

Massari, S. Food Design and food studies: Discussing creative and critical thinking in food system education and research. International Journal of Food Design, 2(1), 117-133. 2017.

Massari, S. ¿Por qué la comida necesita diseño? In "Memorias del 6 Encuentro Latinoamericano de Food Design: DIVERSIDAD". Co-editor con D. Labarca y M. Pasin, Publicado por redLaFD, Chile, ISBN: 978- 9974-8575-8-2. 2018.

Massari, S. Food Design Methods to inspire the new decade. Agency-centered design. Toward 2030. In "Experiencing Food: Designing Sustainable and Social Practices". Proceedings of the 2nd International Conference on Food Design and Food Studies, Lisbon, Portugal, 2019. 2020.

Menezes, Leonardo; Oliveira, Luiz Alberto; org. Pratodomundo -

Comida para 10 bilhões. Museu do Amanhã, 2019.

Meroni, Anna. Strategic Design for the Food Sector: food-system innovation. In: First International Product and Service Design Symposium and Exhibition on Agricultural Industries: Olive Oil, Wine and Design Proceedings. Izmir: Izmir University of Economics, Department of Industrial Design, p.212-223. 2006.

Meroni, Anna. Creative communities. People inventing sustainable ways of living. Milão, Edizioni Polidesign. 2007.

Meroni, Anna. Strategic Design: where are we now? Reflection around the foundations of a recent discipline. In: Strategic Design Research Journal, v1, n.1, Dec 1, p.31-38. 2008.

Meroni, Anna. 4d-conference.com/2017/speaker/anna-meroni/ Acesso em Maio, 2019.

Meroni, A., Sangiorgi, D., Eds. Design for Services. UK: Gower. 2011

Miller, William R. Definition of Design. Original from Buckminster Fuller Institute's website. Tradução de Leite, João, 1997.

Montanari, Massimo. The Culture of Food. Blackwell, 1994

Montanari, Massimo. Food Is Culture. New York: Columbia University Press, 2006.

Nasser, T. G. (s.d.). www.juntalocal.com. Acesso em 14 de abril de 2019.

Nestlé, Marion. Food Politics: How the Food Industry Influences Nutrition and Health. Berkeley: University of California Press. 2002.

Nestlé, Marion. Unsavory Truth. Strand Books, 2018.

Neilson, Lisa. Boycott or Buycott? Understanding Political Consumerism. Journal of Consumer Behaviour. 9. 214 - 227. 10.1002/cb.313. 2010.

Norman, Don. The Design of Everyday Things: Revised and Expanded Edition .2013

de Oliveira, Alfredo Jefferson. Ecovisões projetuais: pesquisas em design e sustentabilidade no Brasil. São Paulo, Edgard Blücher. 2017. 
NUPENS USP. Núcleo de Pesquisas Epidemiológicas em Nutrição e Saúde da Universidades de São Paulo. www.fsp.usp.br/nupens/en/home-en. Acesso em agosto, 2020.

ONU. Agenda 2030. www.nacoesunidas.org/pos2015/agenda2030/. 2015. Acesso em Julho, 2018

ONU. UN Agenda for Sustainable Development Goals, Food and Agriculture Organization of the United Nations, World Food and Agriculture Statistical, Acesso em Maio, 2018.

ONU. Preparations and outcomes of the 2012 United Nations Conference on Sustainable Development (Rio +20). Pocketbook, 2018. http://www.fao.org. Acesso em Abril, 2019

ONU. UN Paris Agreement (https://unfccc.int/process-and-meetings

/the-paris-agreement/d2hhdC1 pcy). Acesso em Junho, 2019.

Pacenti, E. and Sangiorgi D. Service Design Research Pioneers. An overview of Service Design research developed in Italy since the '90s. In Design Research Journal, Ges Ut Av Svid, Stiftelsen Svensk Industridesign, 1(10): 26-33. 2010.

Parreira, Suzana. Design-en-place: Processo de design e processo criativo na alta cozinha. Tese (Doutorado em Design de Comunicação) - Universidade de Lisboa, Lisboa, Portugal. 2014.

Petrini, Carlo. Slow Food. Columbia, Columbia University Press. 2001.

Petrini, Carlo. Gastronomia, direito humano Acervo Online, www.diplomatique.org.br/gastronomia-direito-humano/ 2006. Acesso em maio 2020.

Petrini, Carlo. www.ashoka.org/en/fellow/carlo-petrini 2008. Acesso em junho, 2020.

Petrini, Carlo. https://www.ecodebate.com.br/2010/02/25/alimentos-bonslimpos-e-justos-entrevista-com-carlo-petrini/ 2010. Acesso em julho 2019.

Petrini, Carlo. www1.folha.uol.com.br/saopaulo/2016/06/1779266-e-precisorever-a-producao-de-alimentos-diz-criador-do-slow-food.shtml. 2016. Acesso em maio 2020.

Pollan, Michael. The Omnivore's Dilemma. Penguin Books. 2006.

Pollan, Michael. In Defense of Food. Penguin Books. 2008.

Pollan, Michael. Food From a Farm Near You. The New York Times "On the Table" Blog, Maio, 2006. Acesso em abril 2020.

Pollan, Michael. www.nybooks.com/articles/2020/06/11/covid-19-sickness-foodsupply/. 2020

Portilho, F. Consequências Políticas do Deslocamento da Questão Ambiental para o campo do consumo. In: PORTILHO, F. Sustentabilidade ambiental, consumo e cidadania. São Paulo: Cortez, p. 163 - 218. 2010

Portilho, F. Ativismo alimentar e consumo político - Duas gerações de ativismo alimentar no Brasil. Redes (St. Cruz Sul, Online), Santa Cruz do Sul, v. 25, n. 2, p. 411-432. 2020

Portilho, F. et al. Novos espaços de experimentações: produtores, consumidores e ecochefs em feiras orgânicas cariocas. In: Menezes, S. de S. M.; Cruz, F. T. da (org.). Estreitando o diálogo entre alimentos, tradição, cultura e consumo. São Cristóvão: Editora da Universidade Federal de Sergipe, p. 93-114. 2018.

Portilho, F.; Barbosa, L. A adesão à "causa" rural e da agricultura familiar por consumidores e seus movimentos organizados. In: Marques, F. C.; Conterato, M.; Schneider, S. (org.). Construção de mercados e agricultura familiar: desafios para o desenvolvimento rural. Porto Alegre: Editora da UFRGS, p. 251-273. 2018.

Portilho, F.; Castañeda, M.; Castro, I. R. R de. A alimentação no contexto contemporâneo: Consumo, ação política e sustentabilidade. Ciência e Saúde Coletiva, v. 16, n. 1, p. 99-106, jan. 2011 
Portilho, F.; Ferreira, I. L. Redes alimentares alternativas no Brasil. In: Leite, S. P.; Bruno, R. (org.). O rural brasileiro na perspectiva do século XXI. Rio de Janeiro: Garamond, p. 189-203. 2019.

Portilho, F; Wilkinson, J. Introdução à Seção Temática: Comida e Alimentação na Sociedade Contemporânea. Estudos Sociedade e Agricultura, v. 25, n. 2, UFRJ, 2012.

De Ponti, Giorgio. Global Innovation in Social design and Food Design to increase the sustainability Presentation. Second International Conference on Environmental Design, Turin, 2017.

Poulain, Jean-Pierre. Sociologias da alimentação. Os comedores e o espaço social alimentar. Florianópolis, Ed. UFSC, 2006.

ReLAFD. Revista Latinoamericana de Food Design. Volume 1. Universidad de Buenos Aires, Ciudad Universitaria, Intendente Güiraldes, Argentina; Universidad Pontificia Bolivariana, Instituto Tecnológico Metropolitano, Medellín, Colombia; Red Latinoamericana de Food Design, EUCD; Universidad de la República, Montevideo, Uruguay. www.lafooddesign.org. 2020.

Reissig, Pedro. Food Design, A Visual Atlas. Argentina, Instituto de la Espacialidad Humana, FADU, Universidad de Buenos Aires. 2019.

Roep, D.; Wiskerke, H. Nourishing networks: Fourteen lessons about crEating sustainable food supply chains. Reeds Business Information, 2006.

Romme, Georges. Action research, emancipation and Design Thinking. Journal of Community \& Applied Social Psychology. 14. 495-499. 10.1002/casp.794. 2004.

Sagor, R. Guiding School Improvement Through Action Research. ASCD Washington, 2000.

Sanders, L.; Simons, G. A Social Vision for Value Co-creation in Design. Open Source Business Resource. 2009.

Sangiorgi, D. Building a framework for Service Design Research, EAD conference 'Connexity', Aberdeen. 2009.

Sangiorgi, D. Transformative Services and Transformation Design. International Journal of Design, 5(2), 29-40. 2010.

Sangiorgi, D; Villari B. Community based services for elderly people. Designing platforms for action and socialisation, International Congress on Gerontology: Live Forever. Lisboa. 2006.

Sangiorgi, D., Prendiville, A., Eds. Desiging for Service. Key issues and New Directions. UK: Bloomsbury. 2017.

Santos, Maureen; Glass, Verena, org. Altas do agronegócio: fatos e números sobre as corporações que controlam o que comemos. Rio de Janeiro: Fundação Heinrich Böll, 2018.

Schifferstein, Rick, Valencia, Ana et al. The Design of Smart Product-Service Systems (PSSs): An Exploration of Design Characteristics. International Journal of Design. 9. 13-28. 2015.

Schifferstein, Rick. Differentiating consumption contexts as a basis for diversity in Food Design education: Eating in or Eating out? International Journal of Food Design. 2. 83-101. 10.1386/ijfd.2.1.83_1. 2017

Silva Pinto, Laura de Souza Cota Carvalho. Design relacional: uma possibilidade para a conexão, viabilização e valorização de produtos alimentícios artesanais no Brasil. Orientador: Alfredo Jefferson de Oliveira; coorientador: Roberto dos Santos Bartholo Júnior, PUC Rio, 2016.

Silva; Veloso, A. Focus Group: Considerações Teóricas e Metodológicas. Portugal. Revista Lusófona de Educação, n.26, p. 175-190. 2014.

Simon, H. A. The Sciences of the Artificial. The MIT Press, 1996.

Sloan, Philip; Legrand, Willy \& Hindley, Clare; eds. The Routledge handbook of sustainable food and gastronomy. Routledge, 2015. 
Springmann, Marco; Spajic, Luke et al. The healthiness and sustainability of national and global food based dietary guidelines: modelling study. 2020

Steel, Carolyn. Hungry Cities. vintage Books, 2013.

Steel, Carolyn. Sitopia: How Food can save the world. Chatto \& Windu, 2019.

Steel, Carolyn. www. atlasofthefuture.org/carolyn-steel-urban-visionary-food/. Acesso em Maio, 2019.

Steel, Carolyn. Terra Madre, 2020.

Steele, Eurídice Martínez et al. Dietary changes in the NutriNet Brasil cohort during the covid-19 pandemic. Rev. Saúde Pública vol.54 São Paulo 2020.

Stewart, D.; Shandasani, P. Focus Groups: Theory and Practice (2nd ed.). Thousand Oaks, California. Sage. 2007.

Stickdorn, Marc; Schneider, Jakob. Isto é Design Thinking de Serviços. Bookman, 2014.

Thackara, John. In the Bubble: Designing in a Complex World. The MIT Press, 2006.

Thiollent, Michel. Metodologia da Pesquisa-ação. São Paulo, Cortez. 1986

Van Halen, C.; Vezzoli, C.;Wimmer, R. Methodology for Product Service System Innovation. Uitgeverij Van Gorcum. 2005

Vasconcelos, Ana. Future Food Towards Sustainable Food Pattern. Dottorato di Ricerca in Designo Industriale e Comunicazione Multimediale, Politécnico de Milão.

Vezzoli, C.; Manzini, E. Product-service systems and sustainability: Opportunities for sustainable solutions. Unep Tie. http://www.uneptie.org./scp/design/pdf/pss-imp7.pdf 2002

Vezzoli, Carlo et al. Sistema produto + serviço sustentável : fundamentos. Traduzido por Aguinaldo dos Santos. Curitiba, Insight. 2018.

Verganti, R. Design-Driven Innovation - Mudando As Regras da Competição. São Paulo: Pritchett do Brasil. 2012.

Vianna, M et al. Design Thinking. Business Innovation. Gráfica Cruzado. 2018.

Vogelzang, Marije. Eat Love: Food Concepts by Eating-Designer Marije Vogelzang. 2009

Vogelzang, Marije. www.marijevogelzang.nl/. 2010

Vogelzang,Marije. The Dutch Institute of Food and Design, https://thedifd.com/2018/10/22/the-food-design-manifesto-event/. 2018. Acesso em julho, 2019.

Warde, A. and Martens, L. A Sociological Approach to Food Choice: The Case of Eating Out', in A. Murcott (ed.) The Nation's Diet. Londres, Longman. 1998

Warde, Alan. The practice of Eating. Cambridge: Polity, 2016.

Willett, Rockström, Loken et al. Food in The Anthropocene: the EAT-Lancet Commission on Healthy Diets From Sustainable Food Systems. www.thelancet.com/commissions/EAT. 2019

Wilkinson, J. Mercados, redes e valores: o novo mundo da agricultura familiar. Porto Alegre: UFRGS, 2008.

Wiskerke, Johannes S.C.; Viljoen, André. Sustainable food planning: evolving theory and practice. E-book. 2016

Xavier, Francine Teixeira, org. Isto não é (apenas) um livro de receitas... é um jeito de mudar o mundo. Instituto Comida Do Amanhã. Editora Fundação Heinrich Böll, Rio de Janeiro. 2019.

Zampollo, F. Food and Design: Space, Place and Experience. Hospitality and Society, 2013.

Zampollo, F. Meaningful Eating: A New Method for Food Design. 2013.

Zampollo, F. Introducing Food Design. In S. Cleeren \& A. Smith (eds.), Food Inspires Design (pp. 8-13), Oostkamp, Bélgica. 2013.

Zampollo, F. TED: A Design Method for Meaningful Eating Design. 2014. 
Zampollo, F. The wonderful world of Food Design: A conversation with Marije Vogelzang. International Journal of Food Design, Volume 1, Number 1, p.65-71. 2015.

Zampollo, F. Welcome to Food Design. International Journal of Food Design, Volume 1, Number 1, p.3-9. 2016

Zampollo, F. What is Food Design? The complete overview of all Food Design sub-disciplines and how they merge. 2016.

Zampollo, F. The four Food Design pillars. Online School of Food Design onlineschooloffooddesign.org. published on academia.edu on December 15, 2017.

Zampollo, Francesca. Design Thinking is not enough anymore: this is the era of discipline-specific innovation tools. 10.13140/ RG.2.2.34467.55840.2018

Zampollo, F., Peacock, M. Food Design Thinking. A branch of Design Thinking specific to Food Design. Journal of Creative Behavior, 50(3), 203-210. 2016.

Zanella, Matheus. On the challenges of making a sustainable kitchen: experimenting with sustainable food principles for restaurants. Research in Hospitality Management 2020, Vol. 10 No. 1. 2020.

Zanetti, Tainá Bacellar. Cozinha de Raiz: As relações entre chefs, produtores e consumidores a partir do uso de produtos agroalimentares singulares na gastronomia contemporânea. Tese De Doutorado, UFRGS. 2017. 


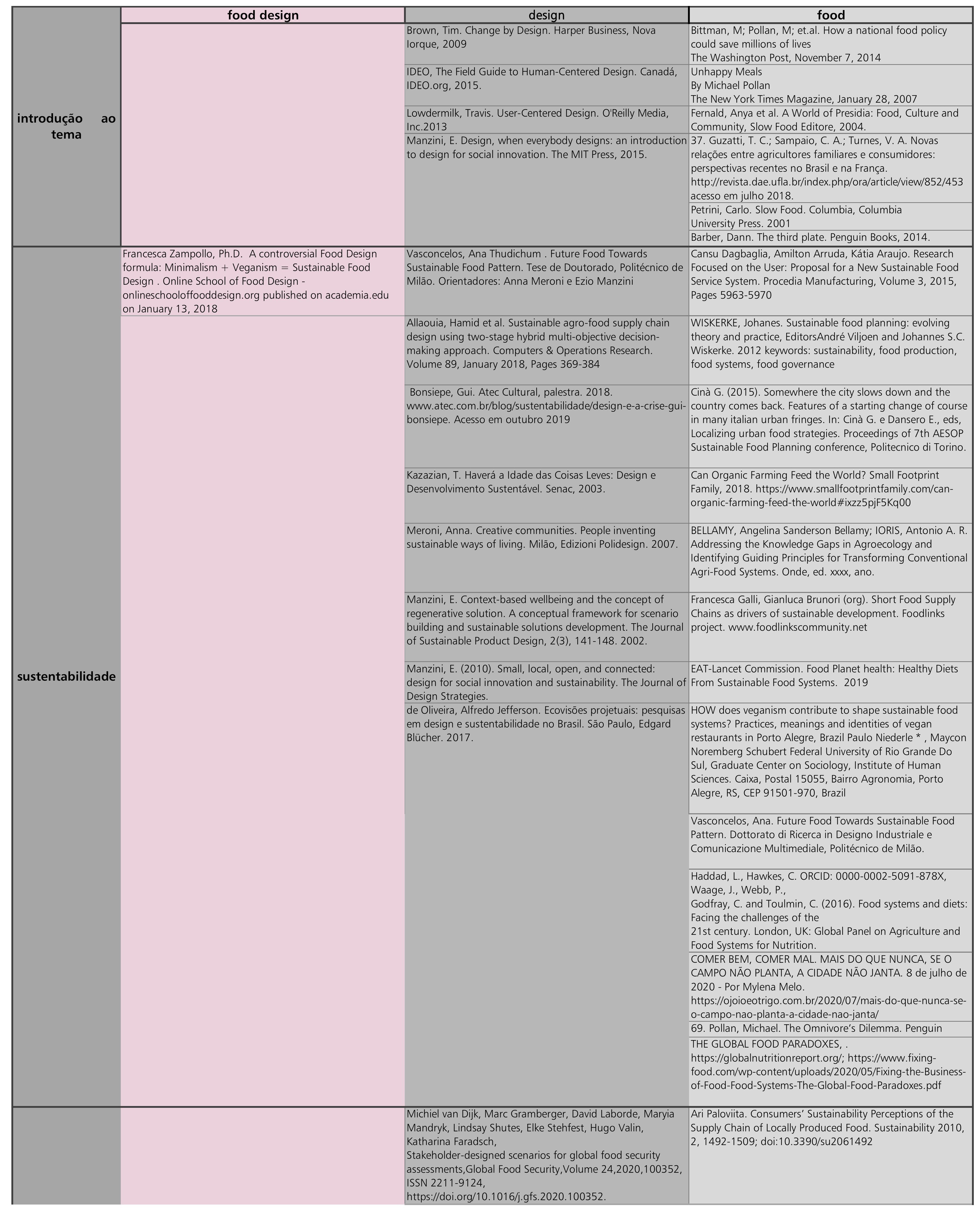


Jochem Jonkman, Ana P. Barbosa-Póvoa, Jacqueline M.

Bloemhof, Integrating harvesting decisions in the design of agro-food supply chains, European Journal of Operational Research, Volume 276, Issue 1, 2019, Pages 247-258, ISSN 0377-2217,

https://doi.org/10.1016/j.ejor.2018.12.024 Eleonora Bottani, Teresa Murino, Massimo Schiavo, Renzo Akkerman. Resilient food supply chain design: Modelling

framework and metaheuristic solution approach. Computers \& Industrial Engineering, Volume 135, 2019, Pages 177 198, ISSN 0360-8352

https://doi.org/10.1016/j.cie.2019.05.011.

Oliveira, alfredo \& Franzato, et al. Ecovisões projetuais: pesquisas em design e sustentabilidade no Brasil. (2017).

"Ideas Sharing LAB". Co-designing multifunctional services with local food communities. Daria Cantù daria.cantu@polimi.it Politecnico di Milano, INDACO dep.

61. Nasser, T. G. (s.d.). www.juntalocal.com. Acesso em 14 de abril de 2018 , disponível em JuntaLocal: www.juntalocal.com
Ministério da Agricultura e da Alimentação. Guide de la restauration collective : favoriser proximité et qualité. França 2014

SCHNEIDER, S. \& FERRARI, D. L.. CADEIAS CURTAS, COOPERACCAO E PRODUTOS DE QUALIDADE NA

AGRICULTURA FAMILIAR - o Processo de Relocalização da Produção Agroalimentar em Santa Catarina. Organizações Rurais \& Agroindustriais, Lavras, v. 17, n. 1, p. 56-71, 2015

Pollan, M. The Sickness in Our Food Supply. The New York Review of Books, May 12, 2020

Marika Zirhama * Roberto Palombab, Female agriculture in the short food supply chain: a new path towards the sustainability empowerment. Agriculture and Agricultural Science Procedia 8 ( 2016 ) $372-377$

3. Gazolla, M., Schneider, S. Cadeias curtas e redes agroalimentares alternativas: negócios e mercados da agricultura familiar. Porto Alegre, Editora da UFRGS, 2016

31. Ferrari, D. L. Cadeias Agroalimentares Curtas: a Construção Social de Mercados de Qualidade pelos Agricultores Familiares em Santa Catarina. Faculdade de Ciências Econômicas, Universidade Federal do Rio Grande do Sul, 2011

Patrizia Longo. Food justice and sustainability: a new revolution. Agriculture and Agricultural Science Procedia 8 ( 2016) $31-36$

Ministério da Agricultura e da Alimentação. RENFORCER LE LIEN ENTRE AGRICULTEURS ET CONSOMMATEURS: Plan d'action pour développer les circuits courts.

O Rio de Costas pro mar. Revista Feira, Primeira edição, Sol Gráfica, Rio de Janeiro, 2018

Pivoto, Dieisson \& Mores, Giana \& Fray da Silva, Roberto \& Spanhol, Caroline. (2016). Cadeias curtas de suprimentos de alimentos: uma oportunidade para os produtores rurais?

Michiel van Dijk, Marc Gramberger, David Laborde, Maryia Mandryk, Lindsay Shutes, Elke Stehfest, Hugo Valin, Katharina Faradsch,

Michiel van Dijk, Marc Gramberger, David Laborde, Maryia Mandryk, Lindsay Shutes, Elke Stehfest, Hugo Valin, Katharina Faradsch,. Stakeholder-designed scenarios for global food security assessments, Global Food Security, Volume 24,2020, 100352, ISSN 2211-9124,

https://doi.org/10.1016/j.gfs.2020.100352.

(http///wmw. sciencedirect.com/science/article/pii/S22119124 20300055)

ECLAC-FAO-IICA BULLETIN. Short food supply chain as an alternative for promoting family agriculture.

41. Ilbery, B.; Maye, D. Alternative(shorter) food supply chains and specialist livestock products in the

Scottish/English Borders. Environment and Planning A. 37 823-844. 10.1068/a3717, 2005

42. Ilbery, B.; Maye, D. Food Supply Chains and

Sustainability: Evidence from Specialist Food Producers in the Scottish/English Borders. Environment and Planning, 2005

73. Roep, D.; Wiskerke, H. Nourishing networks: Fourteen lessons about creating sustainable food supply chains. Reed Business Information, 2006 UN Sustainable Development Goals

De Ponti, Giorgio. Global Innovation in Social design and Food design to increase the sustainability Presentation. Second International Conference on Environmental Design, Turin, 2017.
Sanders, L., \& Simons, G. 2009. A Social Vision for Value Co-

creation in Design. Open Source Business Resource,

Harrison, M. Marsden, T. Consuming Interests: The Social Provision of Foods.Routledge, 2000.

Cipolla, Carla \& Manzini, Ezio. (2009). Relational Services. Knowledge and Policy. 22. 45-50. 10.1007/s12130-009-

9066-z.

Cipolla, C.; Bartholo, R. Empathy or Inclusion:

A Dialogical Approach to Socially Responsible Design.

International Journal of Design, 2014.

Jégou, F.; Bala, P.; Manzini, E. Collaborative Services: Socia Innovation and Design

for Sustainability. Poli Design, 2008.

MERONI, Anna; FASSI, Davide; SIMEONE, Giulia. Social

Frontiers The next edge of social innovation research,

Politecnico di Milano, Department of Design, POLIMI DESIS,

Italy, ano. Service Design, Design Activism, Creative

Communities, Public Space, Food Systems 
Carla Cipolla and Heloisa Moura. Social Innovation in Brazi Through Design Strategy . 2012 The Design Management Institute

Manzini, E., Staszowski, E. (2013). Public and collaborative. Exploring the intersection of design, social innovation and Public Policy. Desis Network.

Sangiorgi, D. Transformative Services and Transformation Design. International Journal of Design, 5(2), 29-40. 2010

Irene Canfora. Is the short food supply chain an efficient solution for sustainability in food market? Agriculture and Agricultural Science Procedia 8 ( 2016 ) 402 - 407

El diseño en el fortalecimiento y la integración del desarrollo regional : Actas $3^{\circ}$ Congreso Latinoamericano de Diseño. -

1 a ed. mejorada. - Rosario: Red DISUR, 2017. Libro digital, PDF Archivo Digital: descarga y online ISBN 978-987-46583$0-2$

Carla Cipolla, Maíra Prestes Joly et al. Service design for social innovation: the promotion of active aging in Rio de Janeiro.

Anna Meroni, Davide Fassi and Giulia Simeone. Design for social innovation as a form of designing activism. An action format. Politecnico di Milano,

"Ideas Sharing LAB". Co-designing multifunctional services with local food communities. Daria Cantù

daria.cantu@polimi.it Politecnico di Milano, INDACO dep.

Manzini, E. (2015). Making things happen: Social innovation and design.

Ballantyne-Brodie, E., Wrigley, C.; Ramsey, R. Evolution of the Docklands Food Hub: A Design-Led Innovation Approach to Food Sovereignty Through Local Food Systems', Journal of Design, Business \& Society 1: 1. 2015

Ballantyne-Brodie, E.; Ramsey, R. et al. Design led innovation to rejuvenate local

food systems and healthy communities: An emerging research agenda. 323-330.

0.1109/TIDMS.2013.6981254. 2013

Brown, Tim; Wyatt, J. Design thinking for social innovation.

Stanford Social Innovation Review, 8(1), 31-35. 201

\section{Meroni,}

Anna. Strategic Design for the Food

Sector: food-system innovation. In: First International

Product and Service

Design Symposium and Exhibition on Agricultural Industries: Olive Oil, Wine and

Design Proceedings. Izmir: Izmir University of Economics, Department of

Industrial Design, p.212-223. 2006

1. Arruda, A. J. Design e Inovação Social. São Paulo, Edgard Blücher. 2017

53. Margolin,

Victor. Design in History. In:

Design Issues, v. 25, n.2, p.94-105. 2009

93. Vezzoli,

C.; Manzini, E. Product-service systems

and sustainability: Opportunities for sustainable solutions.

Unep Tie,

2002. http://www.uneptie.org./scp/design/pdf/pss-imp-7.pdf

FRANQUEIRA, Teresa. Reshaping Urban Lives - Design as

Social intervention towards community networks

François Jégou, Priya Bala, Ezio Manzini. Collaborative

Services: Social Innovation and Design for Sustainability.

Politécninco de Milano, 2008

colaborativo

Cantù, D. (2012). Ideas Sharing Lab. Community Centred

Design for Multifunctional and Collaborative

Food Services. PhD thesis in Industrial Design and

Multimedia Communication, XXIV cycle;

Politecnico di Milano, Italy:

Cipolla, Carla. Solutions for relational services. In: Miettnen,

S. (org). Service Design with Theory. Discussions on Change,

Value and Methods. Rovaniemi: Lapland University Press

(LUP) Publishing. www.sdwiththeory.com/2012/06/sd-withtheory.html (2012)

relacional

Sangiorgi, D; Villari B. Community based services for elderly people. Designing platforms for action and socialisation, International Congress on Gerontology: Live Forever. Lisboa. 2006. 
Francesca Zampollo, Ph.D. Design Thinking is not enough anymore: this is the era of discipline-specific innovation tools. Online School of Food Design -

design thinking onlineschooloffooddesign.org published on academia.edu on January 13,2018

Emily Ballantyne-Brodie \& Dr Ida Telalbasic (2017) Designing STICKDORN, Marc \& SCHNEIDER, Jakob. This is Service local food systems in everyday life through service design strategies, The Design Journal, 20:sup1, S3079- S3095, DOI: 10.1080/14606925.2017.1352816. Design-led food strategy; everyday life politics; service design;

scaling social innovation; localisation.

service design

system design

Wrigley, Cara \& Ramsey, Rebecca. (2016). Emotional food design: From designing food products to designing food systems. International Journal of Food Design. 1. 11-28. 10.1386/ijfd.1.1.11 1. 11IJFD 1 (1) pp. 11-28 Intellect Limited 2016International Journal of Food Design Volume Number 1 $₫ 2016$ Intellect Ltd Article. English language. doi: 10.1386/ijfd.1.1.11_KEYWORDS food design emotional food design, food system design

rene Canfora. Is the short food supply chain an efficient solution for sustainability in food market? Agriculture and Agricultural Science Procedia 8 ( 2016 ) 402 - 407

Nigel Cross. Designerly ways of knowing América Latina, Alta Books, 2008.

Design Thinking Bookman, 2014

Sangiorgi, D. Building a framework for Service 2009 thesis in Industrial Design). Milan. Politecnico di

MilanoUniversity, 2007.

June 2015, Pages 13-21 everyday life. ServDes2018 - Service Design Proof of
Laura de Souza Cota Carvalho Silva Pinto, Design Relacional:

uma possibilidade para a conexão, viabilização e valorização

de produtos alimentícios artesanais no Brasil. Tese de

Doutorado PUC Rio 2016

Brown, Tim. Design Thinking. Harvard Business Review

Agnieszka Tul-Krzyszczuk et al. INNOVATIVE SOLUTIONS

FOR THE DEVELOPMENT OF GASTRONOMY AND MARKET

COMMUNICATION RELATED TO IT. Journal of Agribusiness

and Rural Development. 2015;3(37):575\&\#8211;580 Design Research, EAD conference 'Connexity', Aberdeen.

Cipolla, C. Designing for interpersonal relational qualities in services. A model for service design theory and practice (PhD

Anita R.Linnemanna, Eligius M.T.Hendrixb, RadhikaApaiaha, Megan Horst , Nathan McClintock, and Lesli Hoey. The Tiny A.J.S.van Boekela. Food chain design using multi criteria Intersection of Planning, Urban Agriculture, and Food decision making, an approach to complex design issues. Justice. Journal of the American Planning Association,

NJAS - Wageningen Journal of Life Sciences Volumes 72-73, Summer 2017, Vol. 83, No. 3

Emily Ballantyne-Brodie. Designing convivial food systems in Concept. Politecnico di Milano. 18th-19th-20th, June 2018

Emily Ballantyne-Brodie \& Dr Ida Telalbasic (2017) Designing local foodsystems in everyday life through service design strategies, The Design Journal, 20:sup1, S3079-\$3095,

DEAKIN, Lynda. IDEO's Approach to Designing a Better Food System. Podcast under: Creative Confidence Series, design for Food. Acessado em 14 de outubro de 2019

Francesca Zampollo, Ph.D, Toward a sub-categorization of

the food design aspects: a Food Design wheel. 2012

Francesca Zampollo, Ph.D, Welcome to Food Design

International Journal of Food Design, 2015, Volume 1

Number 1, p.3-9

Francesca Zampollo, Ph.D, The wonderful world of Food

Design. A conversation with Marije Vogelzang. International

Journal of Food Design, 2015, Volume 1, Number 1, p.65-

71

Francesca Zampollo, Ph.D. What is Food Design? The complete overview of all Food Design sub-disciplines and how they merge. Online School of Food Design -

onlineschooloffooddesign.org Published on Academia.edu on November 23, 2016

Francesca Zampollo, Ph.D. The four Food Design pillars.

Online School of Food Design -

onlineschooloffooddesign.org

published on academia.edu on December 15, 2017

Zampollo, Francesca. Welcome to Food Design. Editorial

Published in International Journal of Food Design, 2015,

Volume 1, Number 1, p.3-9

Francesca Zampollo. The wonderful world of Food Design. A conversation with Marije Vogelzang. Editorial Published in

International Journal of Food Design, 2015, Volume 1

Number 1, p.65-71

The Food Design Manifesto Event - The Dutch Institute of

Food Design

ZAMPOLLO, F. Toward a sub-categorization of the food

design aspects:

a Food Design wheel. 2012

Zampollo, Francesca. Food Design for Business. Paper

food design presented at the conference Design For Business: Research Conference,

Melbourne 12-13 May 2015.

Zampollo, F. Introducing Food Design. In S. Cleeren \& A

Smith (eds.), Food Inspires Design (pp. 8-13), Oostkamp,

Bélgica. 2013 
Zampollo, Francesca. (2013). Food and design: Space, place

and experience. Hospitality \& Society. 3.

10.1386/hosp.3.3.181_2.

https://pt.slideshare.net/FrancescaZampollo/what-is-fooddesign-69458366

3rd International conference on food and Design, Food

Design Thinking 101

https://onlineschooloffooddesign.teachable.com

httos://issuu com/ecolesconde/docs/food desian 25.04.14

https://issuu.com/desianenaineeringharvard/docs/mde food

Marije Vogelzang. The Food and Design Manifesto

www.thedifd.com/articles/the-food-design-manifesto/ 2018

Brito, Bruna Ramires. Relações entre design e gastronomia

no cenário contemporâneo / Bruna Ramires Brito, 2018123

f. : il. Orientadora: Mônica Cristina de Moura Dissertação

(Mestrado)-Universidade Estadual Paulista. Faculdade de

Arquitetura, Artes e Comunicação, Bauru, 2018

PARREIRA, Suzana. Alimentação, comida e Design.

Universidade de Lisboa, Lisboa, Portugal.. 2012

PARREIRA, Suzana. Design-en-place: Processo de design e

processo criativo na alta cozinha. 2014. Tese (Doutorado em

Design de Comunicaça o) - Universidade de Lisboa, Lisboa,

Portugal.

Chiaradia, Bruna; Bentz, Ione M. G.; Costa, Filipe C.X. O

Percurso Gerativo de Significação no Food Design: um

estudo sobre os episódios da série Chef's Table. UNISINOS,

2016

Stephanie Marsden. The Squid, The Ink, The Paper and The

Artist:How do artist-led projects engage members of the

public with the complexities of food?. Queen Margareth

University MSc

Gastronomy 2017/18
BONSIEPE, Gui. Design, Cultura e Sociedade. São Paulo, ed. Blucher, 2011.
Steel, Carolyn. Hungry City: How Food Shapes our Lives. Londres. Vintage books. 2013

86. Steel, Carolyn. Sitopia: How Food can save the world. Chatto \& Windu, 2019Stewart, D.; Shandasani, P. Focus Groups: Theory and Practice (2nd ed.). Thousand Oaks, California. Sage. 2007.

81. Schifferstein, Rick. Differentiating consumption contexts 54. MARGOLIN, V. Design Studies and Food Studies: as a basis for diversity in food design education: Eating in or Parallels and Intersections. Design and Culture, v. $5, n .3$, p. eating out? International Journal of Food Design. 2. 83-101. 10.1386/ijfd.2.1.83_1. 2017 143-177, 2015.
MARGOLIN, S. Um modelo

social de design: questões de prática e pesquisa. Revista Design em Foco, v. 1, n. 1, p. 43-48, 2004. art and society
CASSOL, Abel; SCHNEIDER, Sérgio, Produção e consumo de (in: Lua Nova, São Paulo, $95:$

BARBOSA, Lívia. Feijão com arroz e arroz com feijão: o Brasil no prato dos brasileiros. Horizontes Antropológicos, vol 13 n28, Porto Alegre, julho/dezembro 2007

BARBOSA, Lívia. Tendências da alimentação contemporânea

60. Massimo Montanari. Food Is Culture. New York: Columbia University Press, 2006).

72. POULAIN,

Jean-Pierre. Sociologias da alimentação. Os comedores e o espaço social

alimentar. Florianópolis, Ed. UFSC, 2006.

62. Nestlé,

Marion. Unsavory Truth.Strand Books,

2018.

Azzurra Annunziataa, Riccardo Vecchio Organic farming and sustainability in food choices: an analysis of consumer preference in Southern Italy Agriculture and Agricultural Science Procedia 8 ( 2016 ) $193-200$

Pollan. Michael. O Dilema do Onívoro

Pollan, Michael. In Defense of Food

Pollan. Michael. Food Rules

Fatima Portilho. Sustentabilidade ambiental. consumo e

Instituto Comida do Amanhã. Isto não é apenas um livro de 34. Goodman, D., Dupuis, E. Knowing food and growing food: beyond the production-consumption debate in the sociology of agriculture. Sociologia Ruralis Volume 42, Issue 1, pp 5-22, 2002.

35. Goodman, D. The quality 'turn' and alternative food practices: Reflections and agenda. Journal of Rural Studies, 2003

70. Portilho, F; Wilkinson, J. Introdução à Seção Temática: Comida e Alimentação na Sociedade Contemporânea. Estudos

Sociedade e Agricultura, v. 25, n. 2, UFRJ, 2012.

Nestlé, Marion. Unsavory Truth: How Food Companies Skew the Science of What We Eat

Claudia Paciarotti, Francesco Torregiani. Short food supply chain between micro/small farms and restaurants: An exploratory study in the Marche region. British Food Journal. ISSN: 0007-070X. Publication date: 6 August 2018

Nicole Torres. Why Sourcing Local Food Is So Hard for Restaurants. Harvard Business Review Home, 2016 


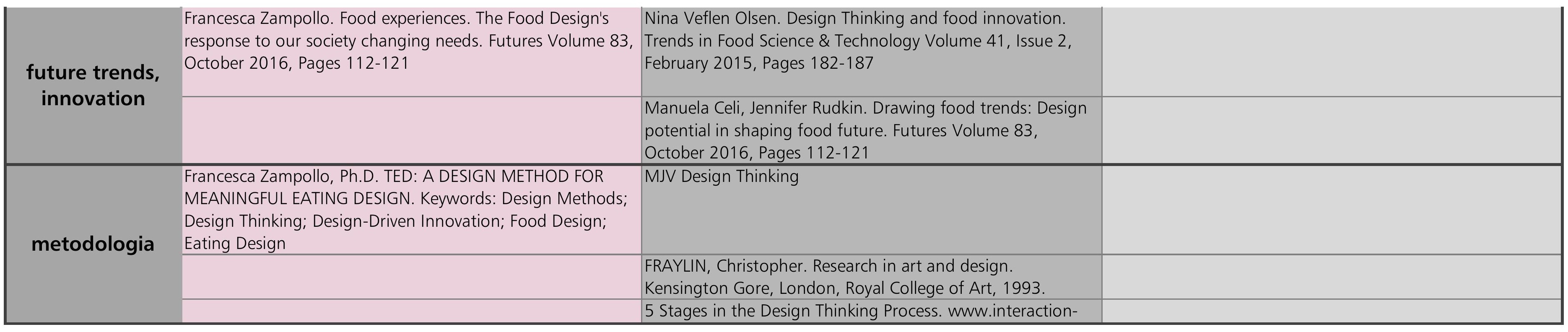




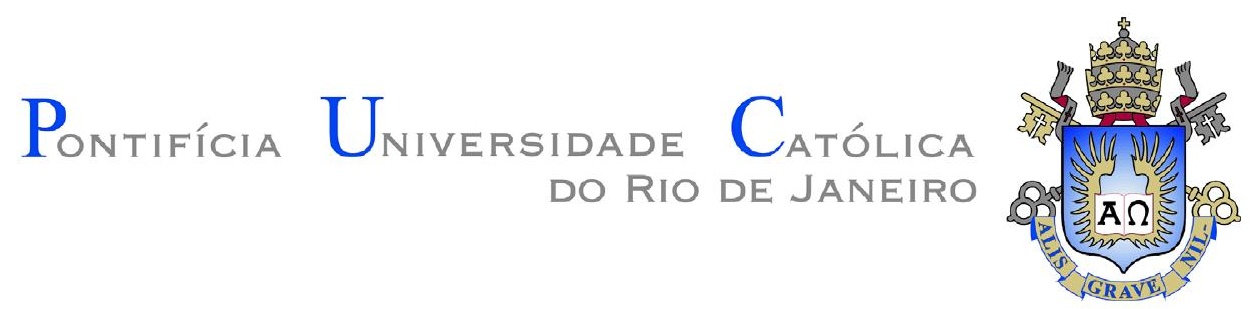

TERMO DE CONSENTIMENTO LIVRE E ESCLARECIDO/ ANUÊNCIA DE DADOS

Gostaríamos de convidar você a participar como voluntário (a) da pesquisa "Food Design: Um olhar sistêmico sobre o papel do chef de cozinha". O motivo que nos leva a realizar esta pesquisa é a consciência de que há uma necessidade iminente de modificar os padrões de produção e consumo vigentes, com foco em soluções sustentáveis para todo o sistema. Nesta pesquisa pretendemos levantar dados quantitativos e qualitativos que permitam identificar e analisar o papel desempenhado pelos chefs de cozinha na cadeia de consumo de alimentos. Caso você concorde em participar, vamos fazer uma entrevista semi-estruturada, com perguntas abertas, com o objetivo de construir um cenário para melhorar a compreensão do problema. Esta pesquisa não oferece riscos, uma vez que não serão identificados os autores das falas, e este termo protege o anonimato. A pesquisa pode ajudar a desenvolver práticas de conexão direta entre os atores da cadeia de produção e consumo de alimentos e consolidar a aproximação entre produtores e consumidores.

Para participar deste estudo você não vai ter nenhum custo nem receberá qualquer vantagem financeira. Apesar disso, se você tiver algum dano causado pelas atividades que fizermos com você nesta pesquisa, você tem direito a indenização. Você terá todas as informações que quiser sobre esta pesquisa e estará livre para participar ou recusar-se a participar. Mesmo que você queira participar agora, você pode voltar atrás ou parar de participar a qualquer momento. A sua participação é voluntária e o fato de não querer participar não vai trazer qualquer penalidade ou mudança na forma em que você é atendido. Os resultados da pesquisa estarão à sua disposição quando finalizada. Seu nome ou o material que indique sua participação não será liberado sem a sua permissão.

Este termo de consentimento encontra-se impresso em duas vias originais, sendo que uma será arquivada pelo pesquisador responsável e a outra será fornecida a você. Os dados coletados na pesquisa ficarão arquivados com o pesquisador responsável por um período de 5 (cinco) anos. Decorrido este tempo, o pesquisador avaliará os documentos para a sua destinação final, de acordo com a legislação vigente. Os pesquisadores tratarão a sua identidade com padrões

profissionais, atendendo as legislações brasileiras (Resoluções $N^{\circ}$ 510/16 e № 466/12 do Conselho Nacional de Saúde), utilizando as informações somente para os fins acadêmicos e científicos.

Mediante ao disposto no Artigo $9^{\circ}$ da Resolução 510/16 CNS no que diz: "São direitos dos participantes": " $V$ - decidir se sua identidade será divulgada e quais são, dentre as informações que forneceu, as que podem ser tratadas de forma pública;".

Declaro que concordo em participar da pesquisa, que me foi dada à oportunidade de ler e esclarecer as minhas dúvidas e que minha identidade e os dados obtidos como respostas da (s) entrevista(s) e discussões em grupo poderão ser divulgadas. Recebi uma via original deste termo de consentimento livre e esclarecido e me foi dada à oportunidade de ler e esclarecer as minhas dúvidas.

Rio de Janeiro, 28 de Outubro de 2019.

Participante

Ellen Gonzalez - Pesquisadora

Alfredo Jefferson de Oliveira

Responsável e orientador. Programa de Pós Graduação PUC-Rio, Departamento de Artes e Design

Contato: 21979121385 .gnzellen@gmail.com 
De: Juliana Lopes

Enviado:Sunday, January 3, 2021 5:34 PM

Para: Ellen Gonzalez

Assunto: Re: Termo de autorização de uso - Mestrado Ellen Gonzalez

Li o termo e concordo em participar da pesquisa.

Juliana Carvalho Lopes

151305067-23

Em dom, 3 de jan de 2021 02:44, Ellen Gonzalez <gnzellen@gmail.com> escreveu:

Olá turma

Espero que estejam todos bem. Como alguns de vocês não preencheram a declaração no Relatório Final, envio por aqui o Termo de Consentimento livre e esclarecido de sua participação na minha pesquisa. Por favor, se concordar com o abaixo descrito, responda esse email dizendo "Li o termo e concordo em participar da pesquisa" com seu nome completo e CPF.

Em função da pandemia corrente, esse aceite por email terá o efeito de assinatura.

Agradeço mais uma vez a participação e empenho nesse semestre tão intenso, e espero vê-los ainda nessa jornada!

Até logo,

Ellen Gonzalez

Os membros do grupo - ou

aluno(a) se em trabalho

individual - confirmam

terem sido informados e

estarem cientes de que

todo o material deste

relatório de projeto e o correspondente PPT (ou similar) de apresentação oral, e eventuais vídeos, fotos e outros materiais relacionados, poderá ser utilizado para fins exclusivamente acadêmicos, nas atividades de pesquisa do grupo Rio DESIS Lab coordenado pela prof. Carla Cipolla e por seus orientandos e coorientandos de mestrado e doutorado, em particular Ellen Gonzalez. 


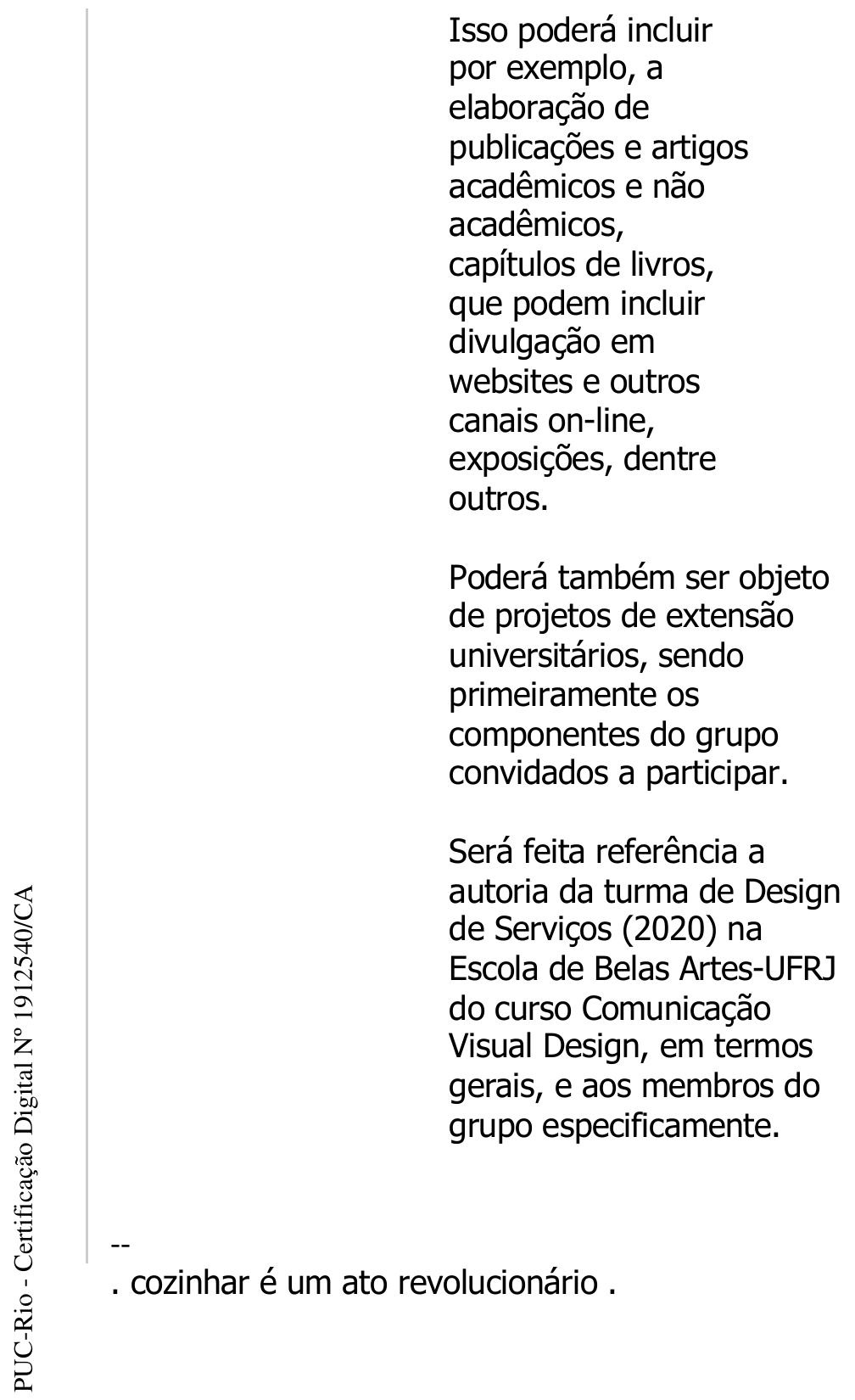




\section{Entrevistas semi-estruturadas}

Escollha a refeiçăo mais completa e varidad do seu dia e responda às proposiçöes abaiixo. Pense sobre o processso produtivo, beneficiamento,
embalagem, deslocamento e armazenamento desses alimentos.
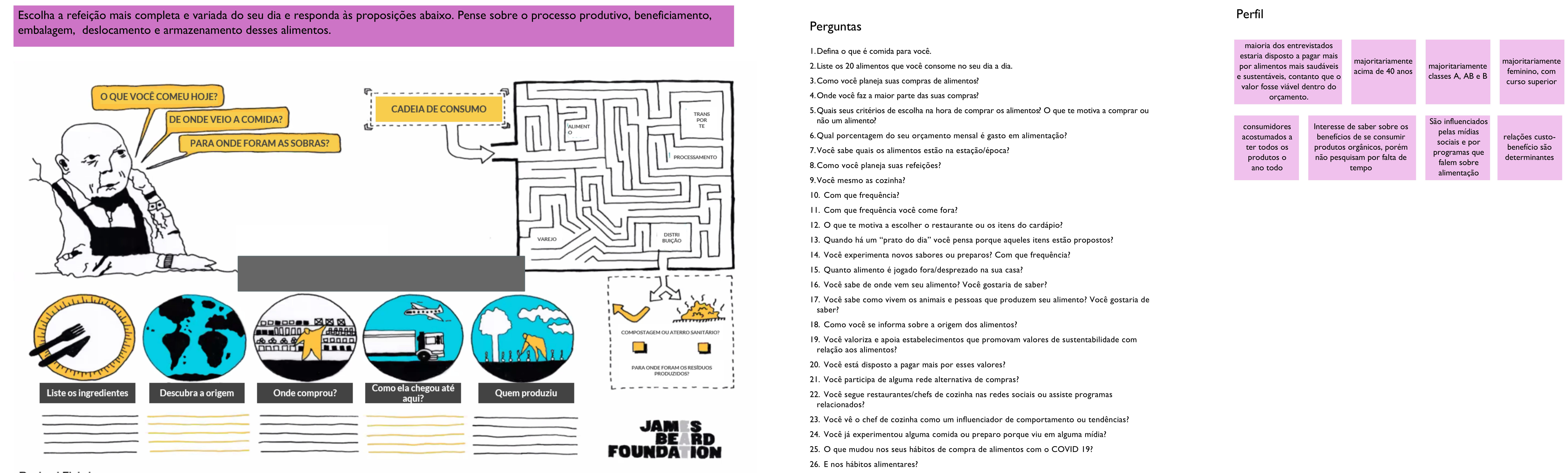

FOUMA 


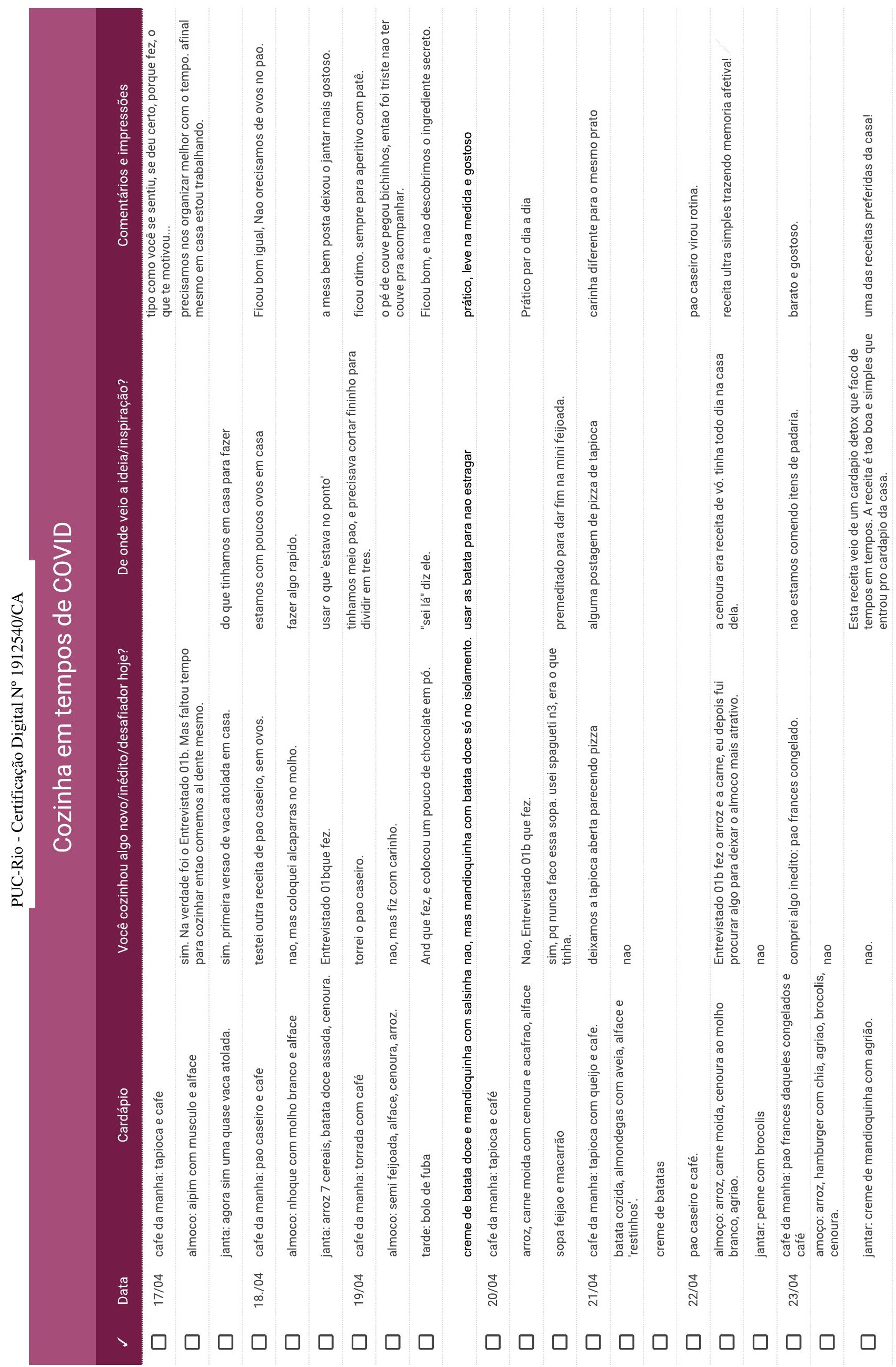




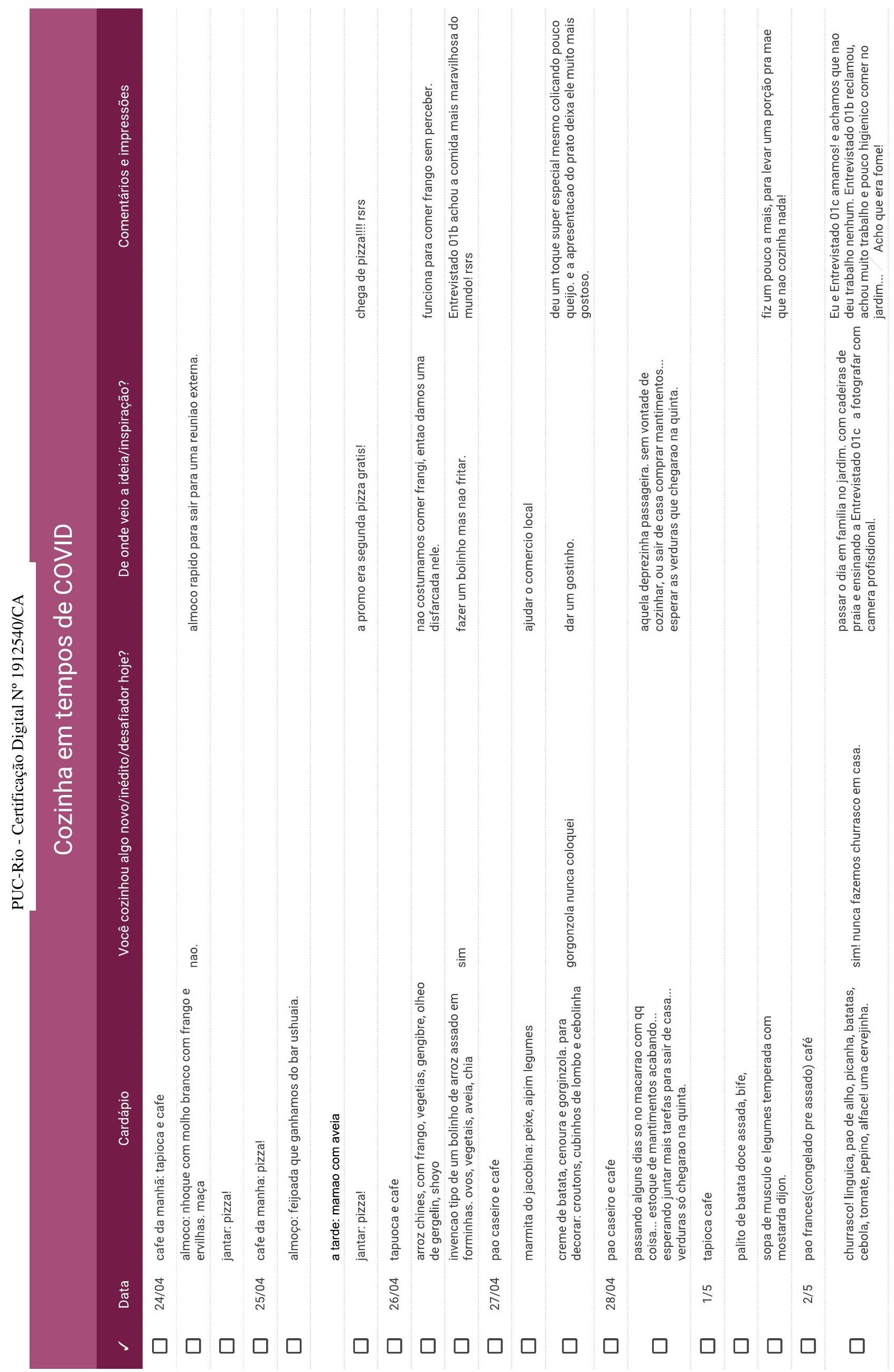




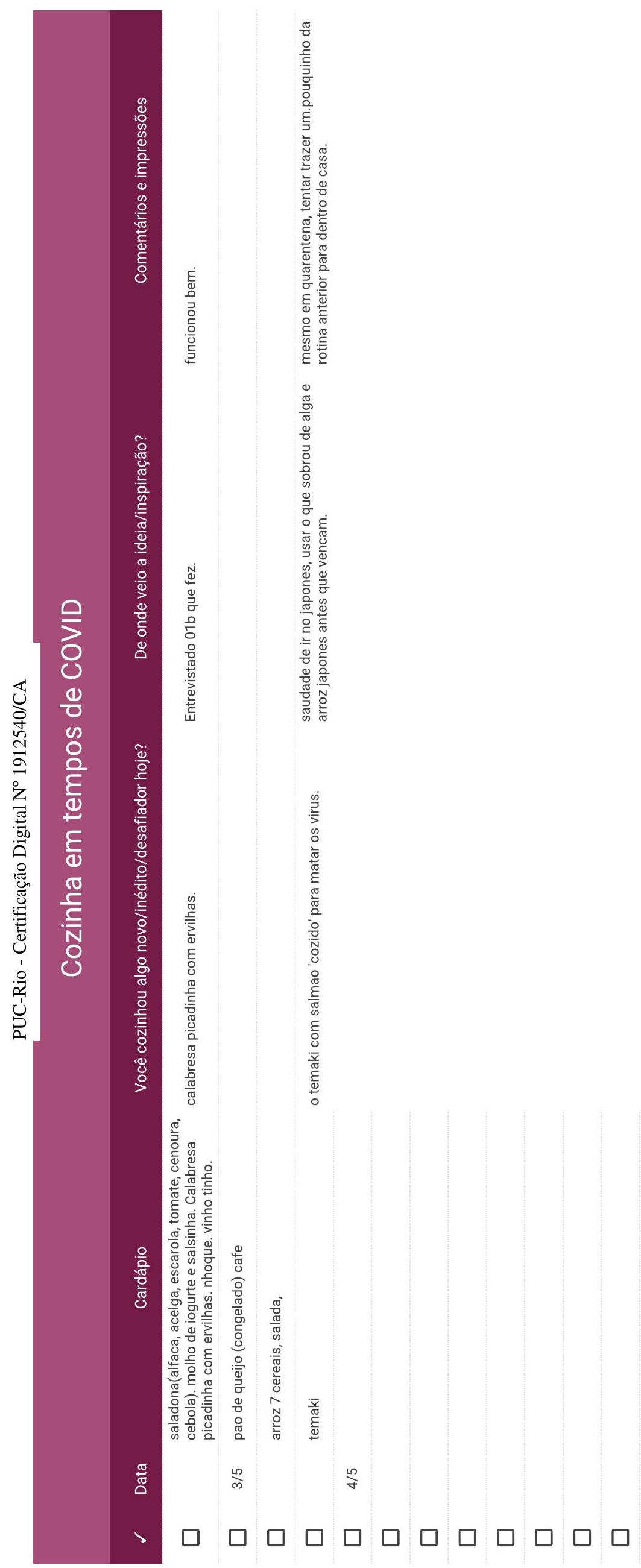




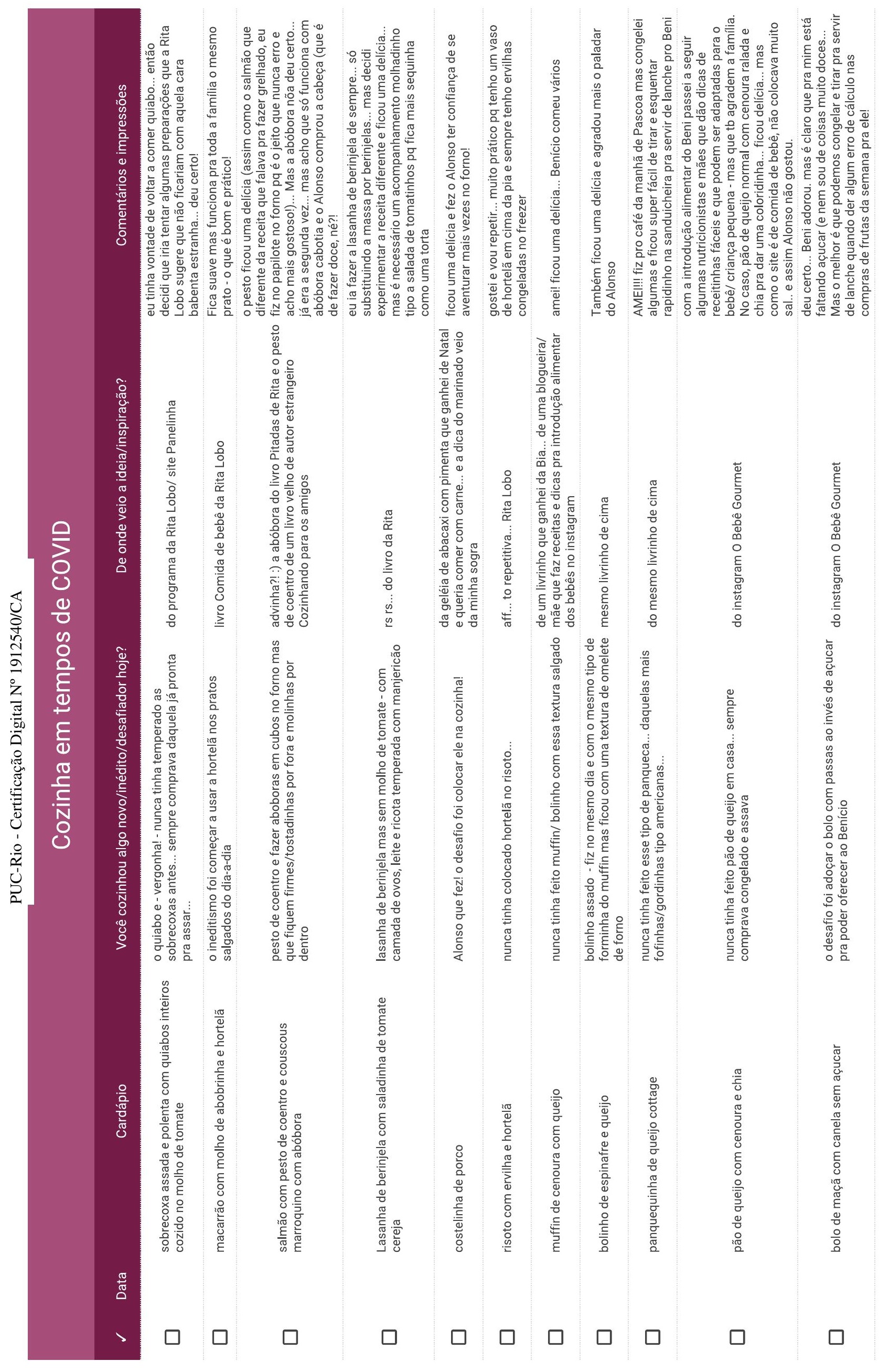




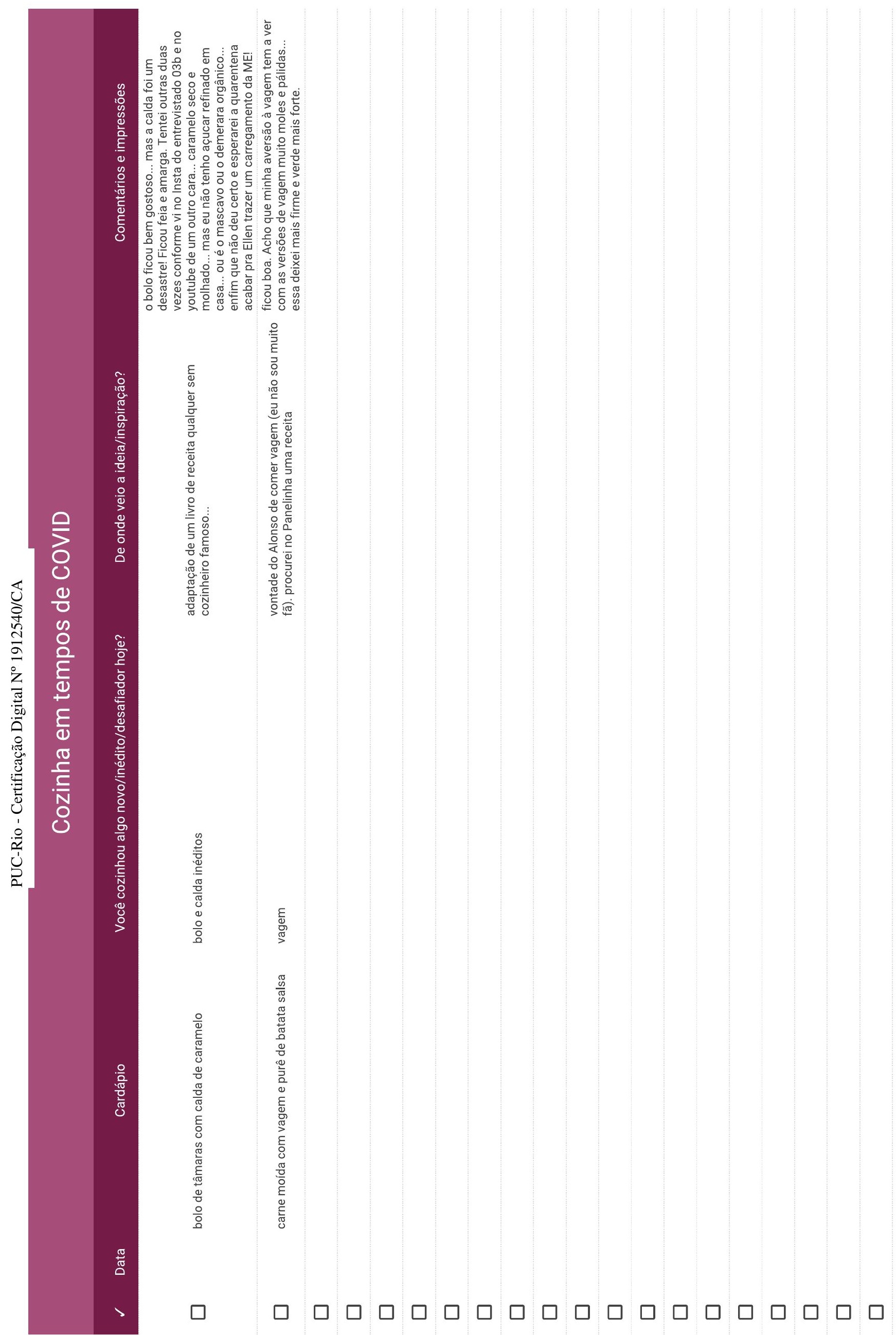




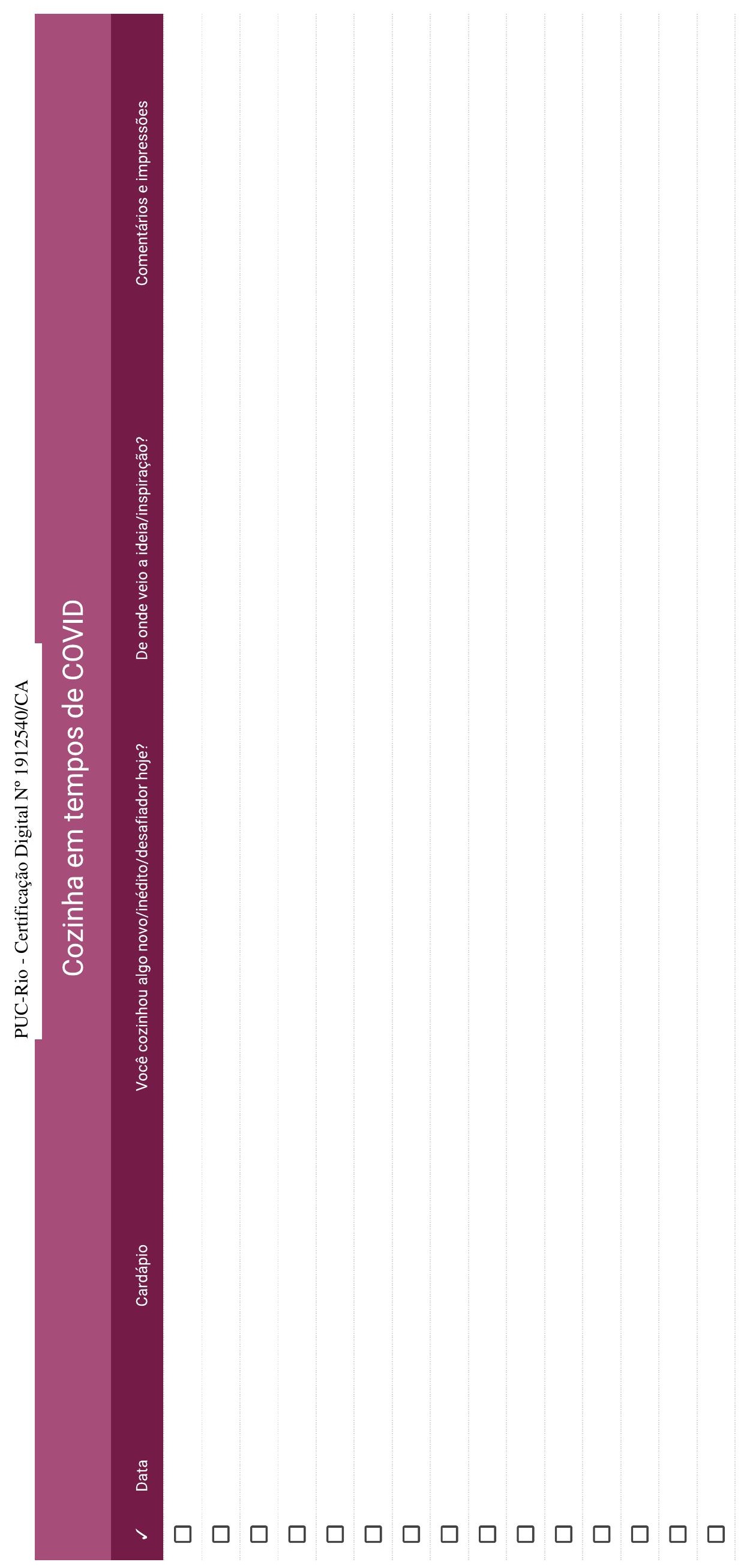




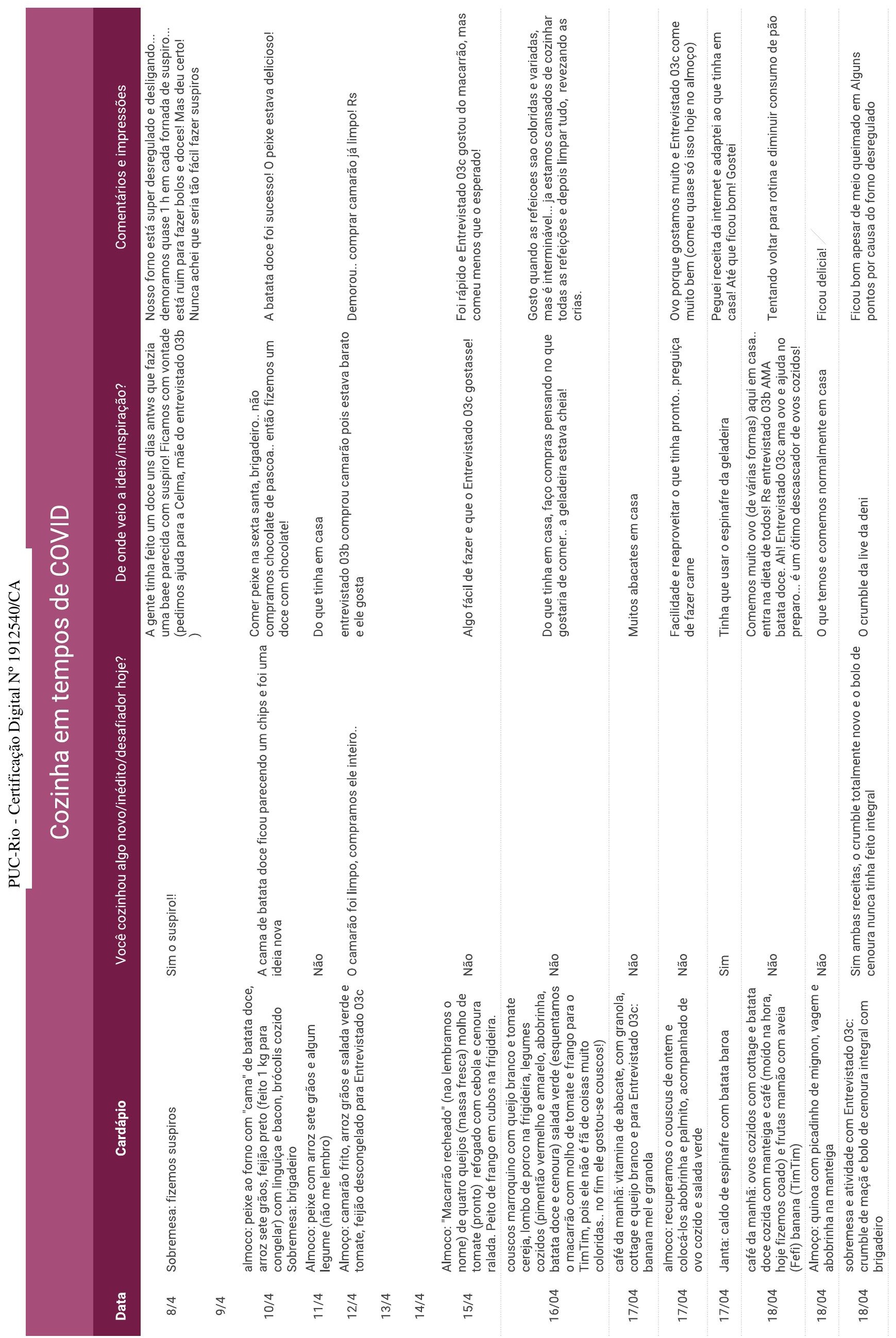




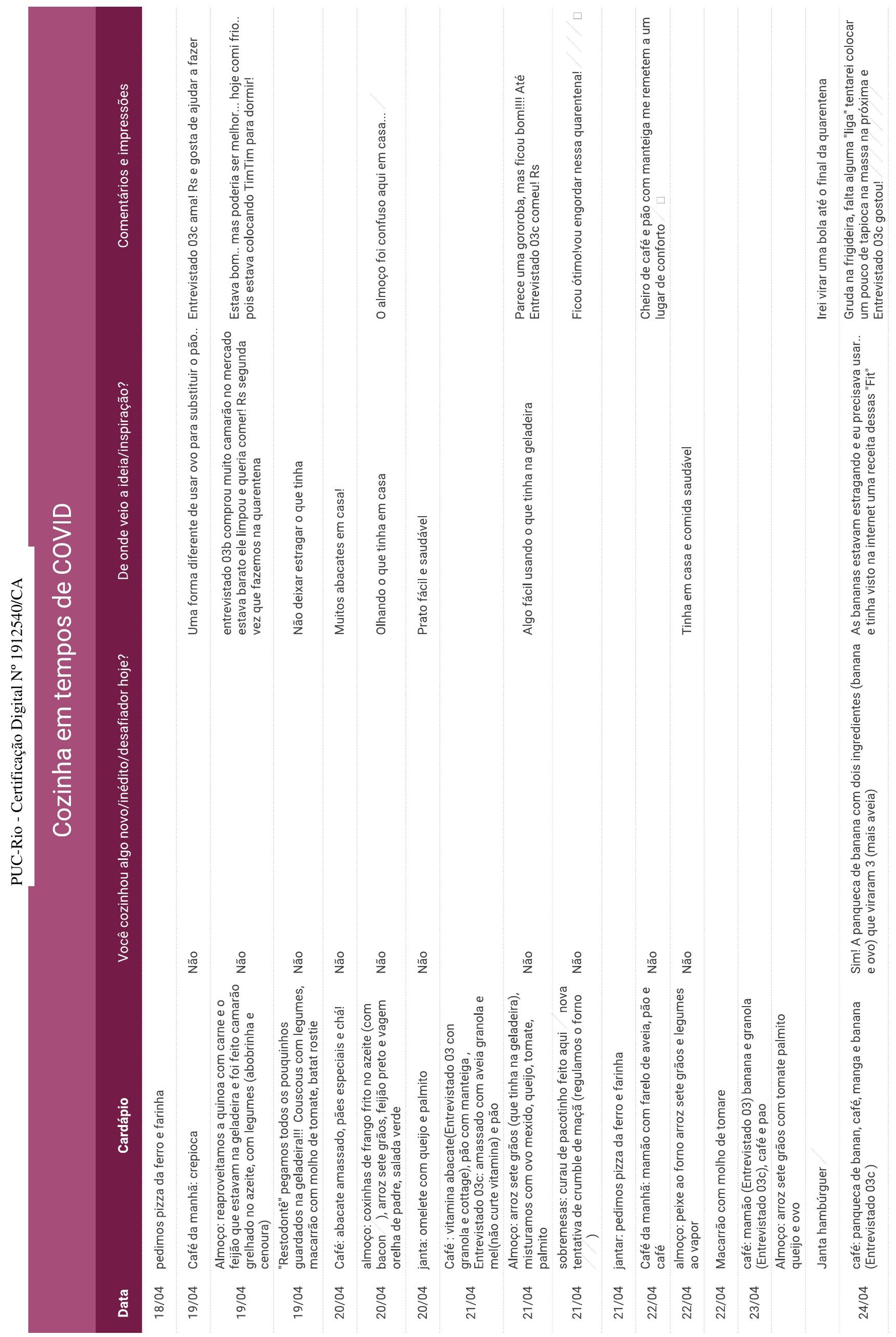




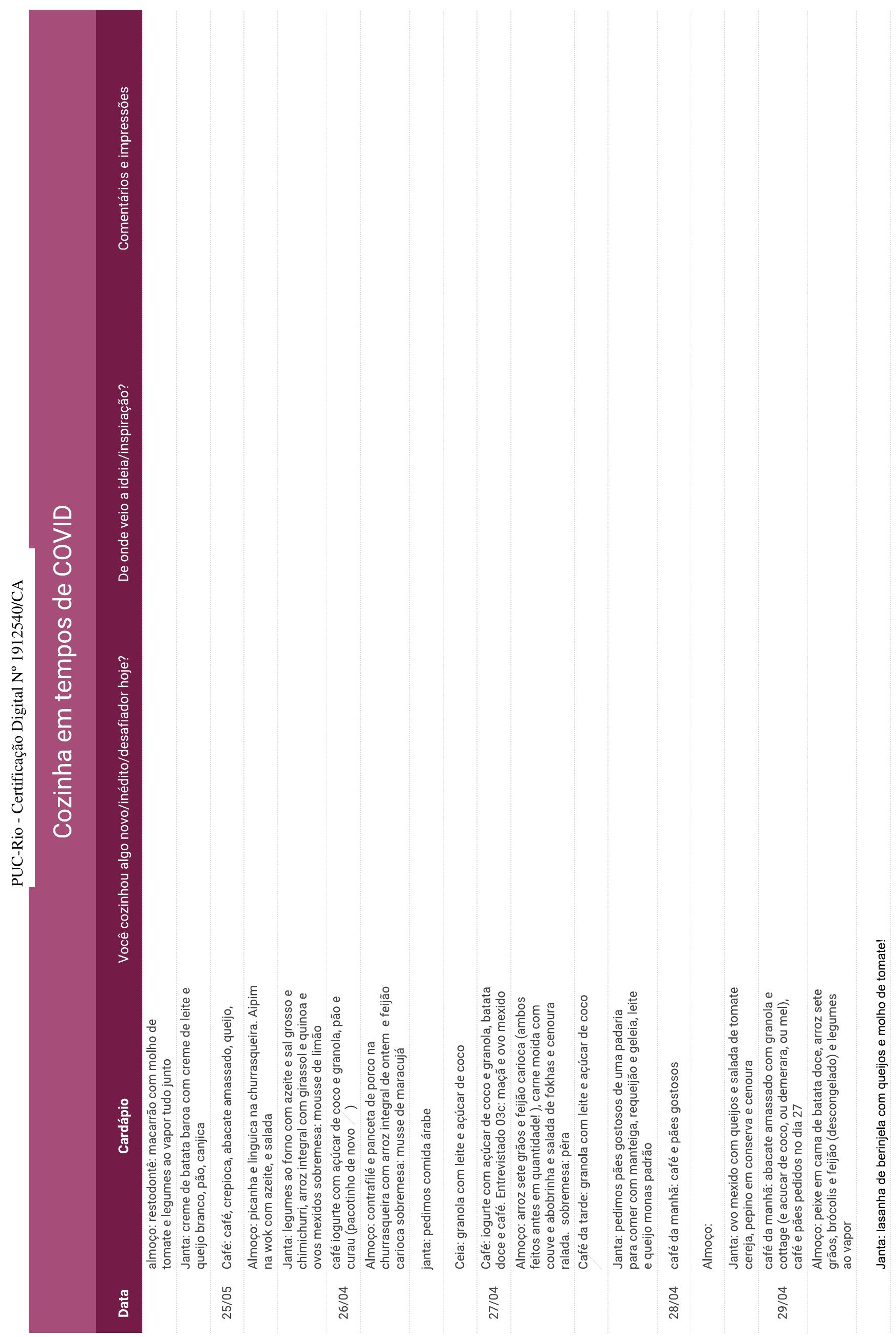



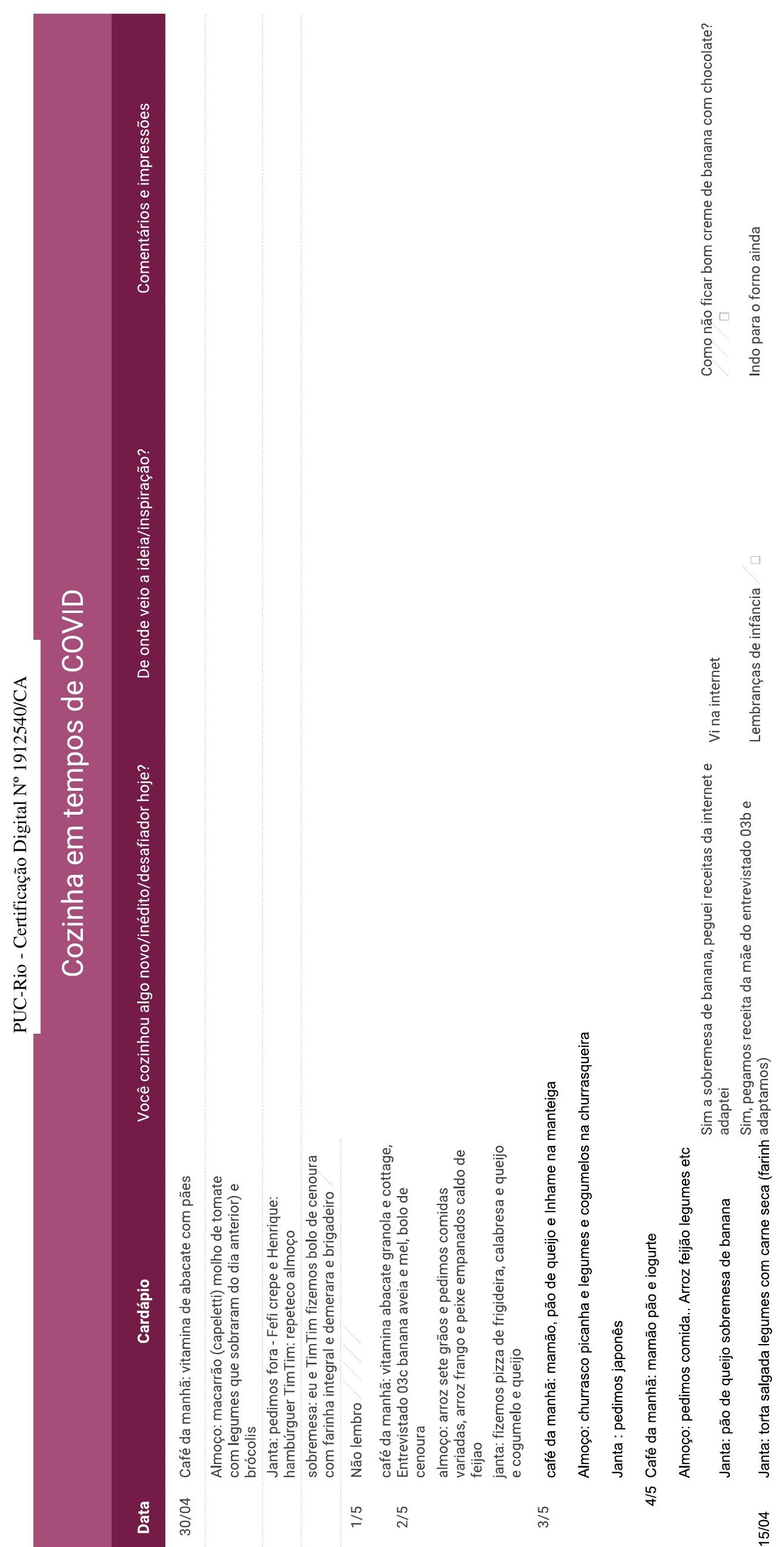


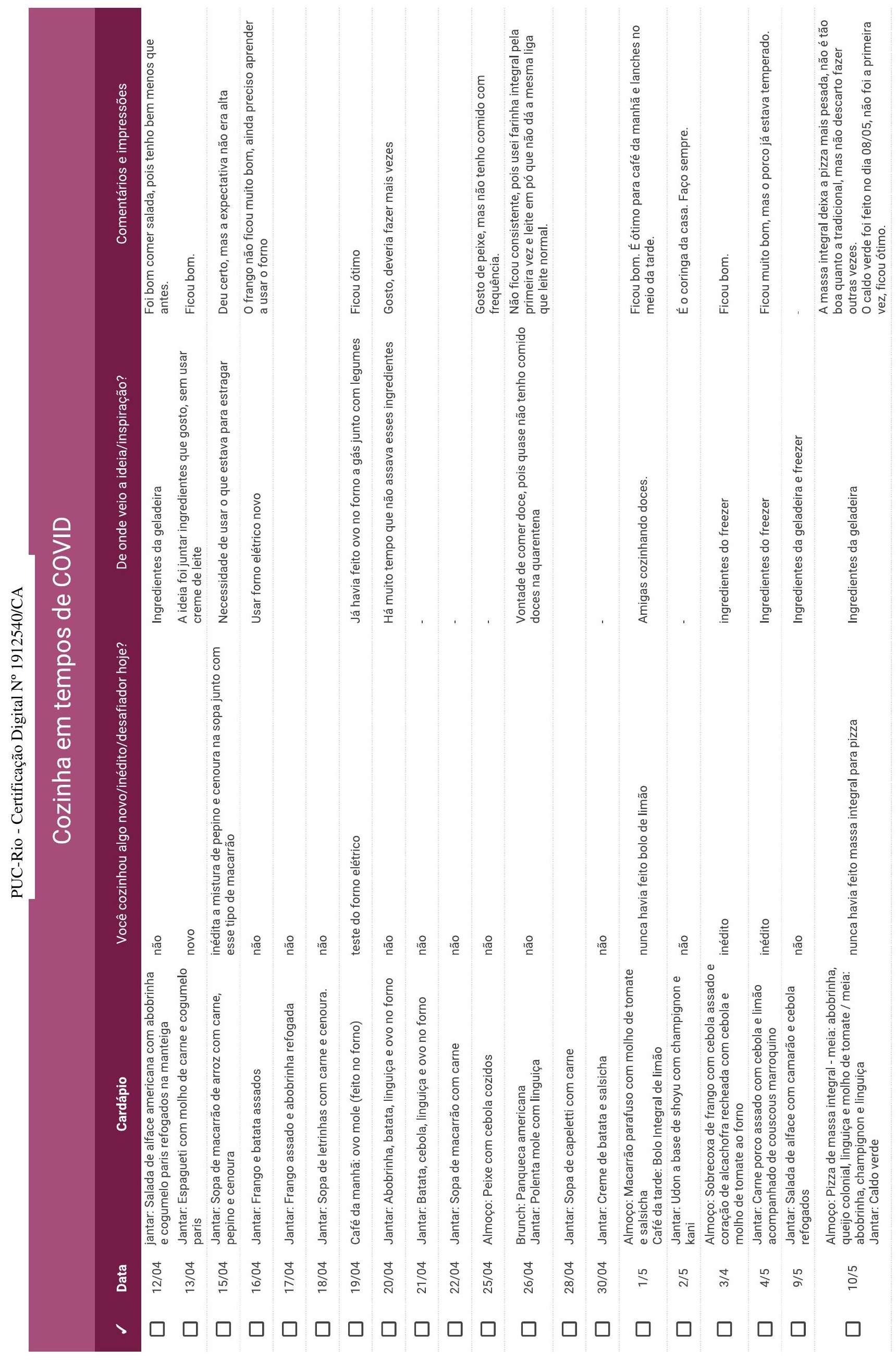




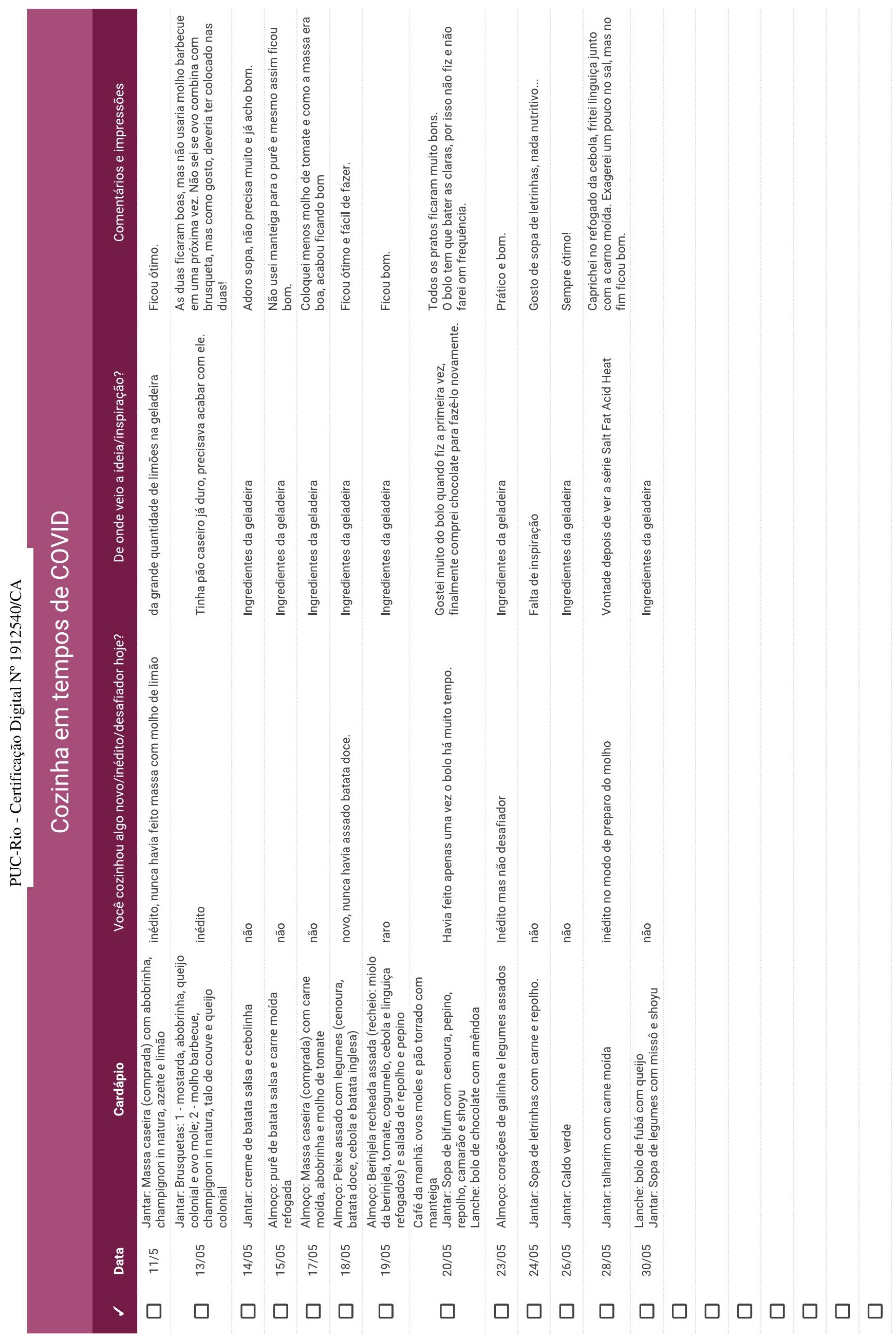




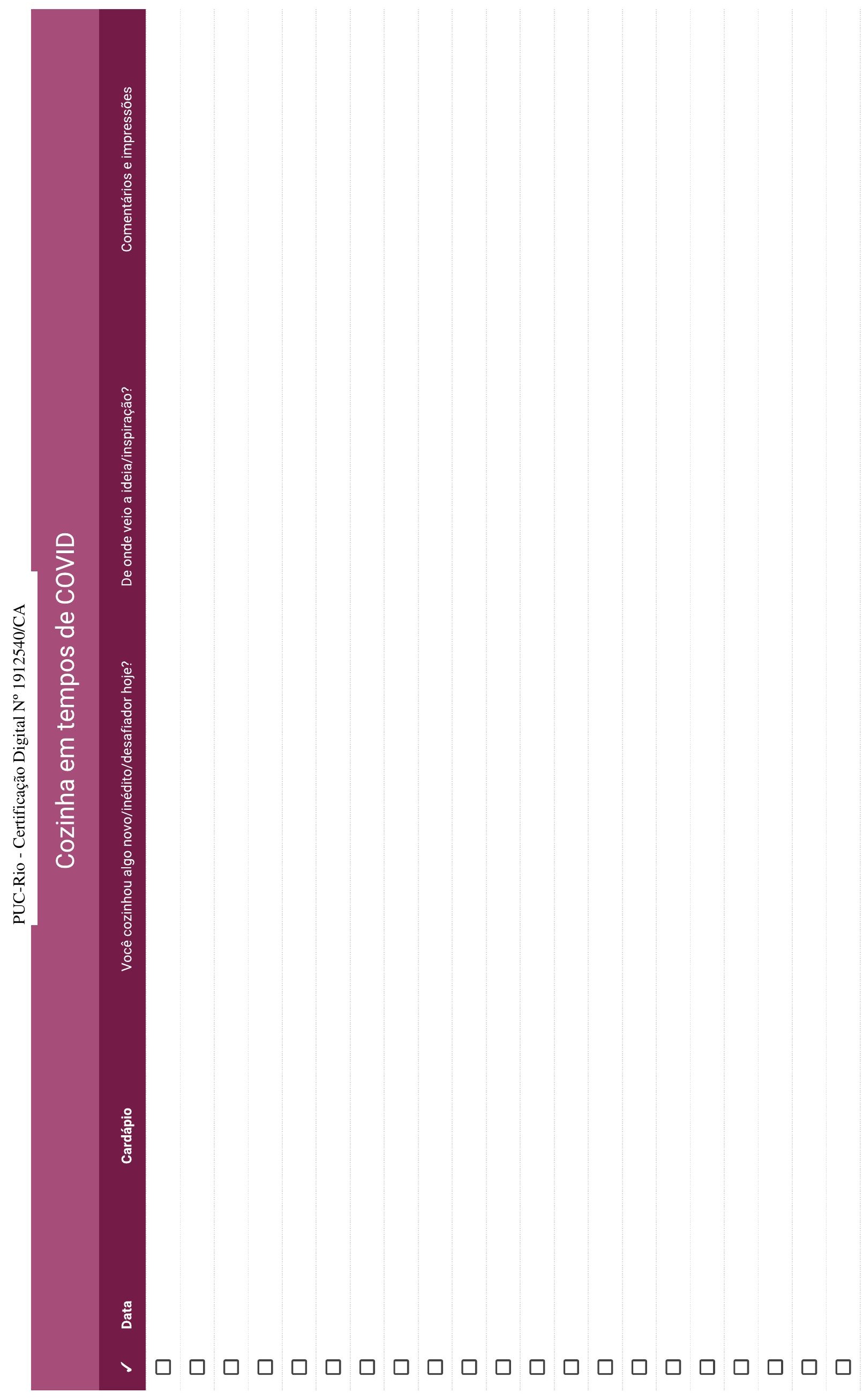




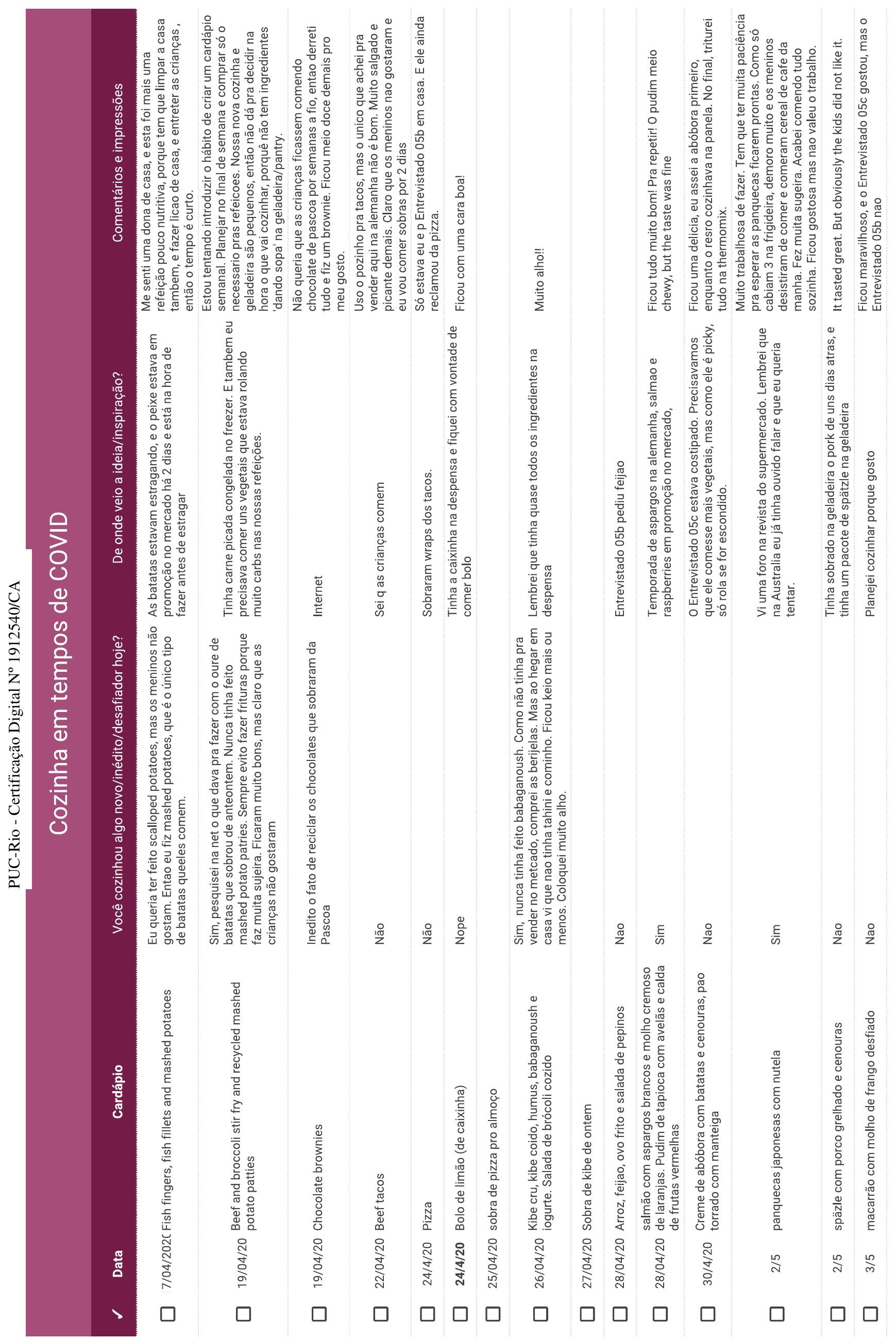




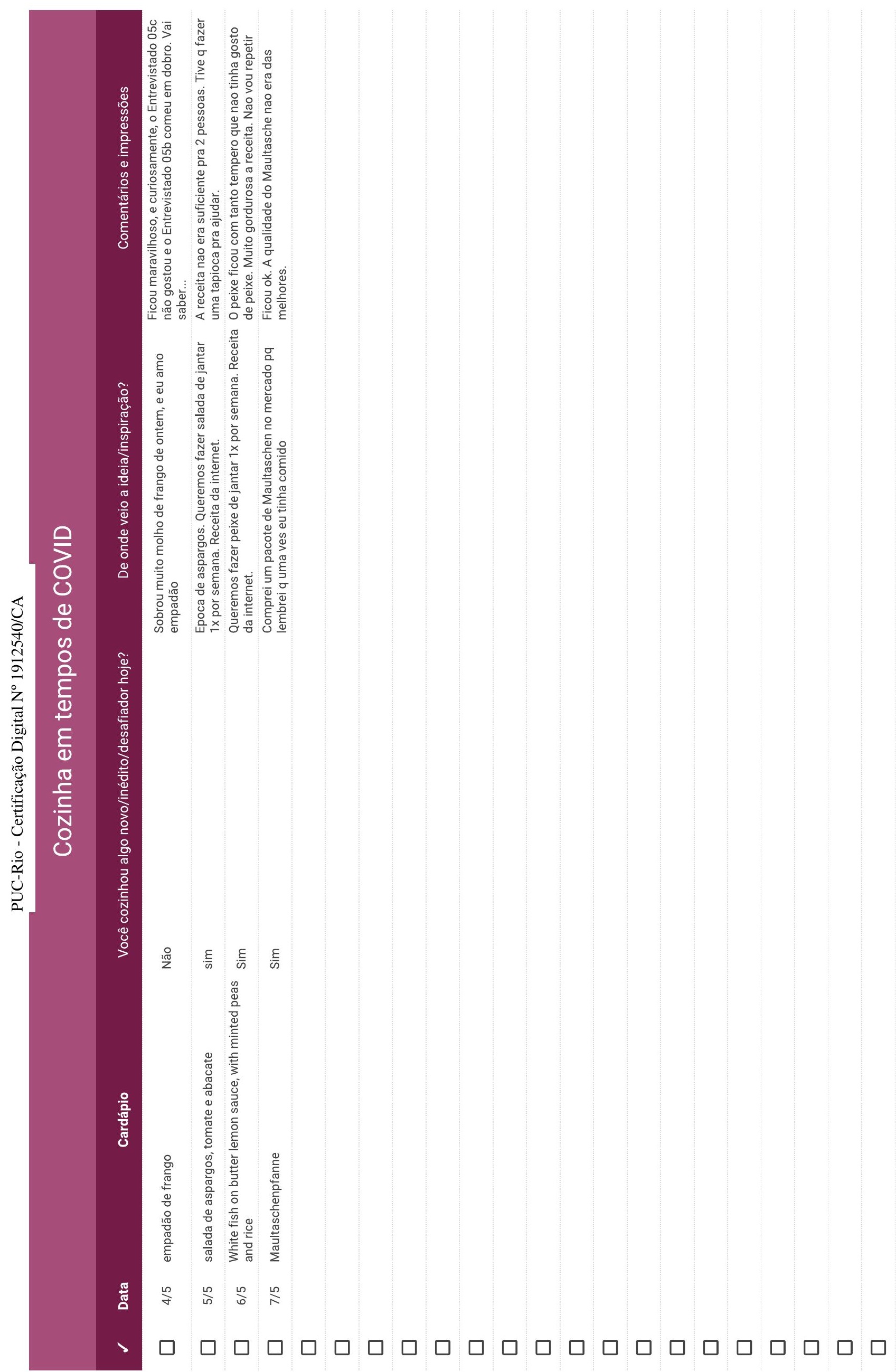




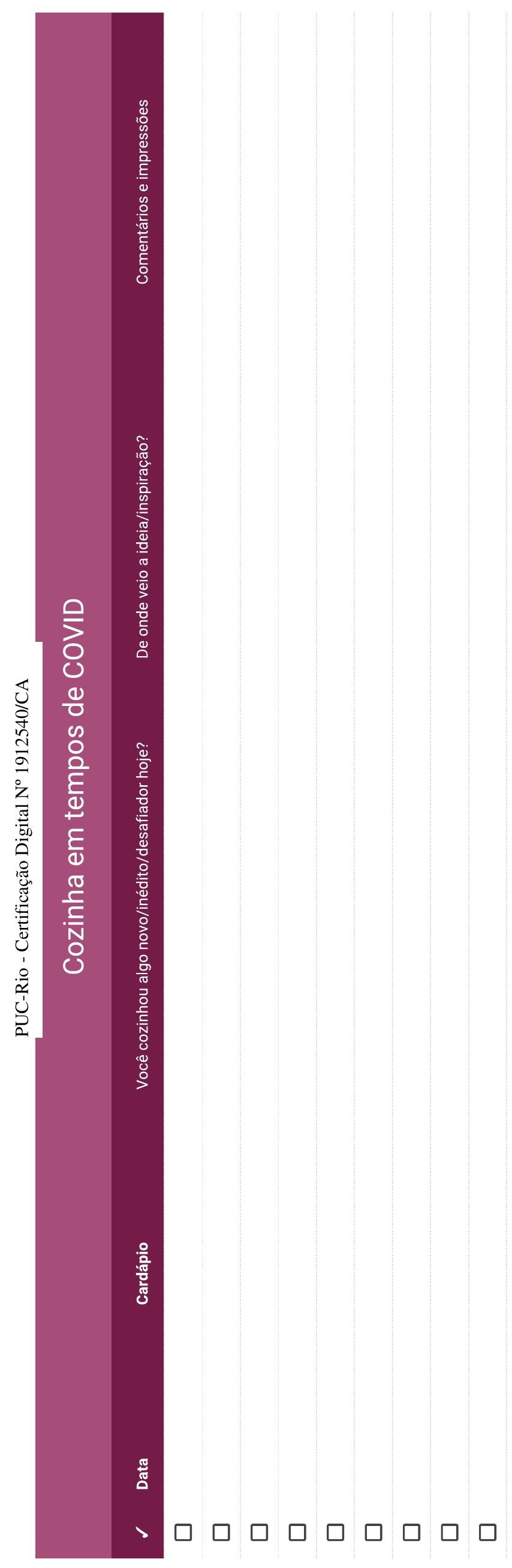




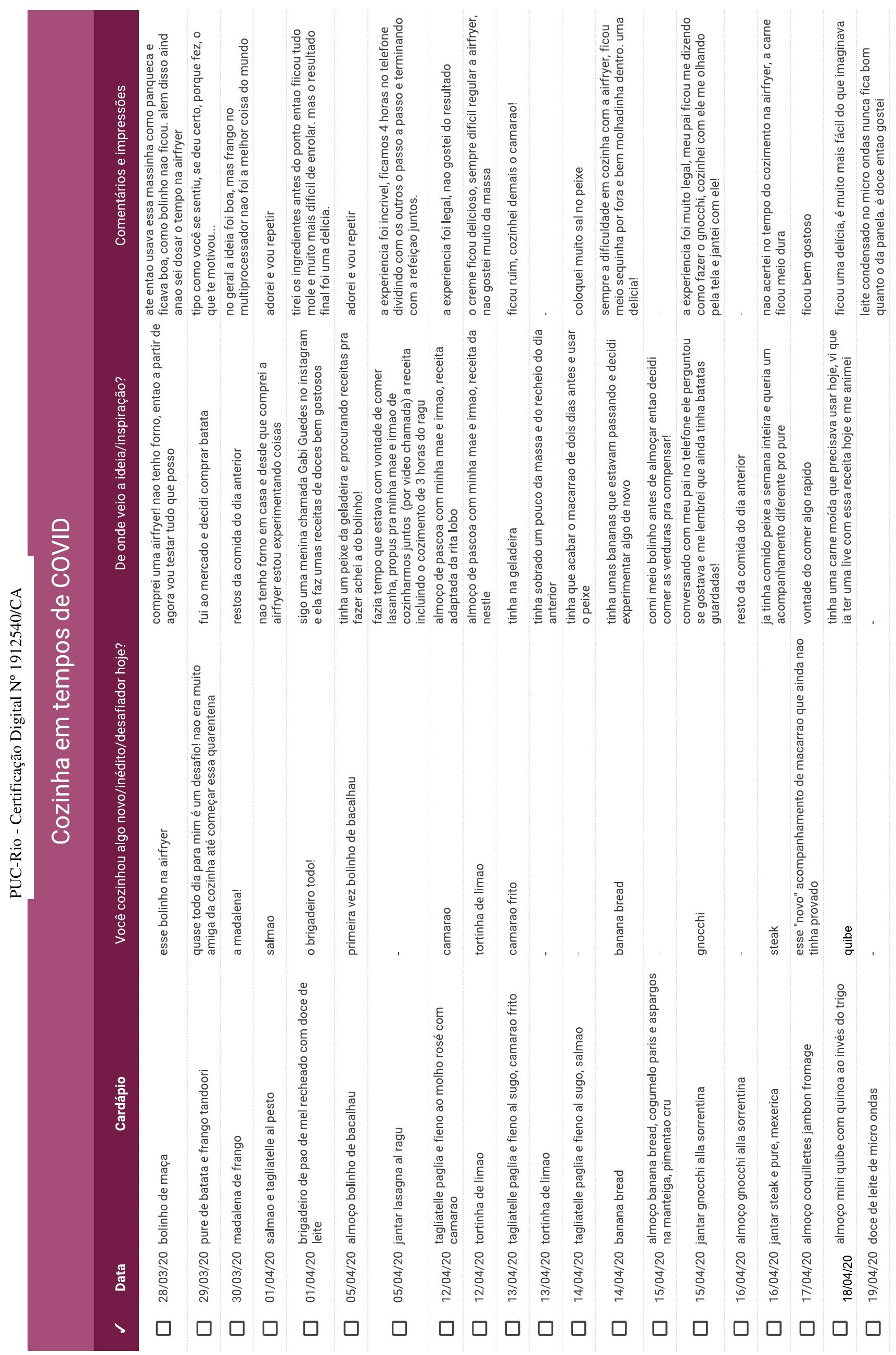




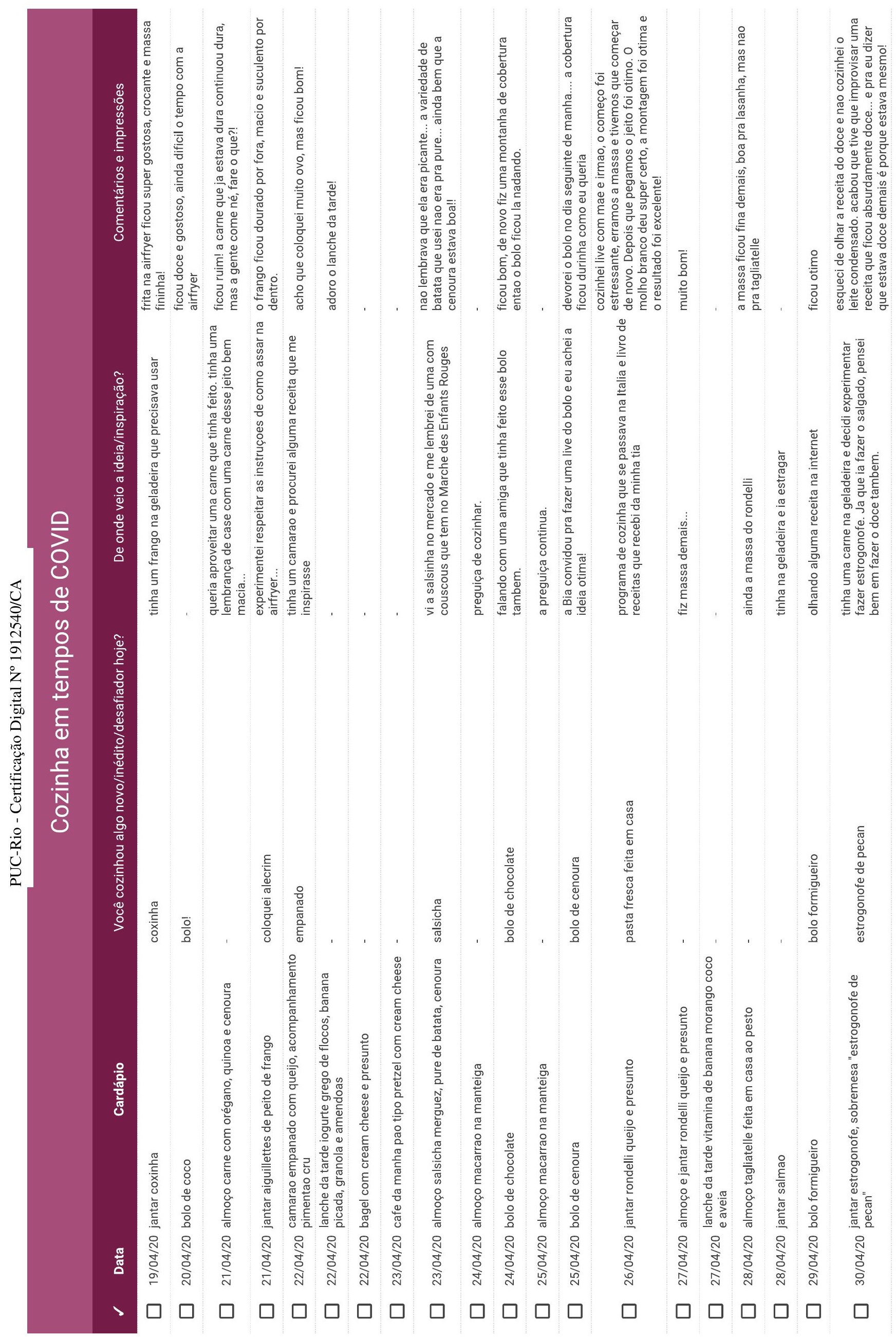




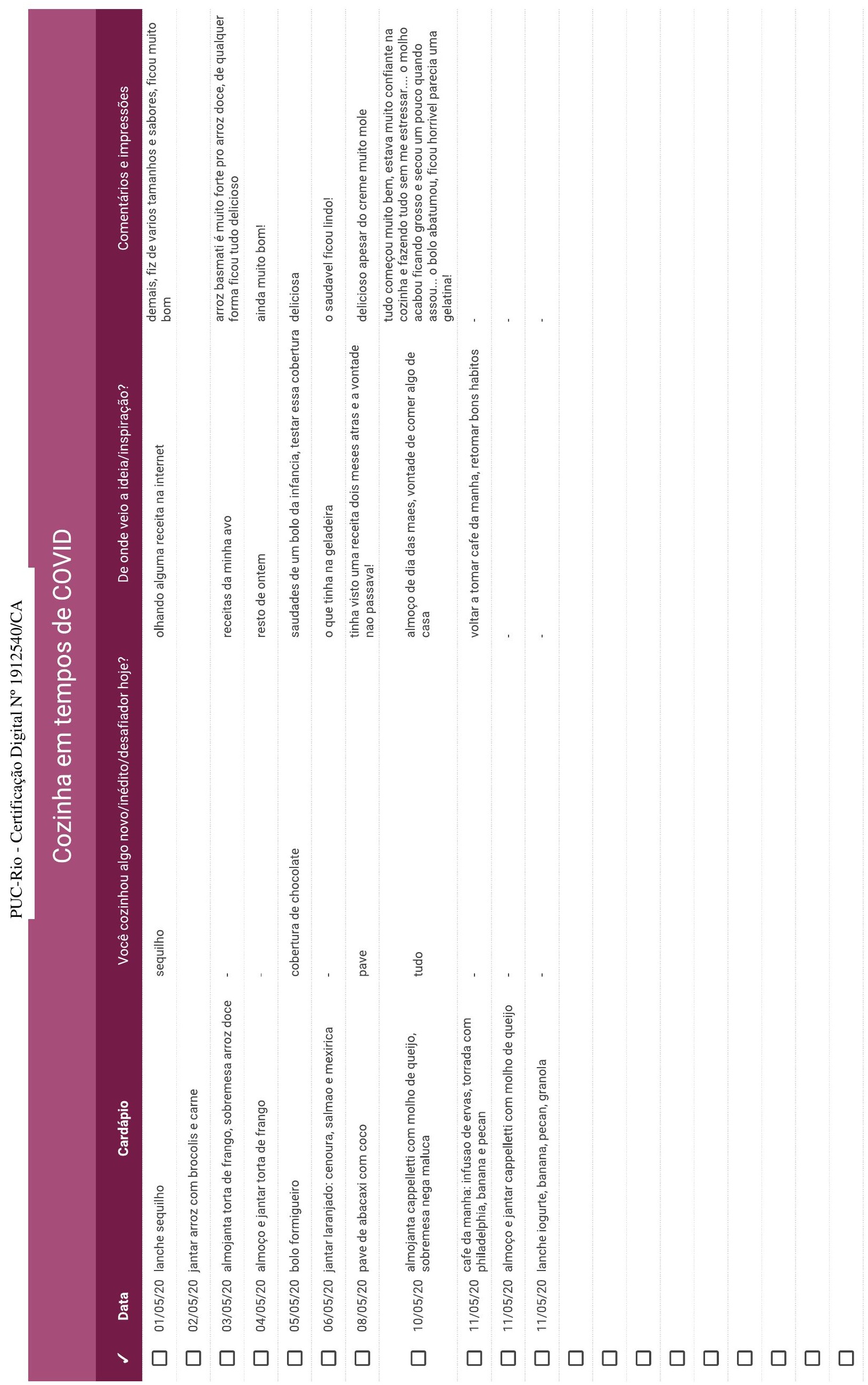




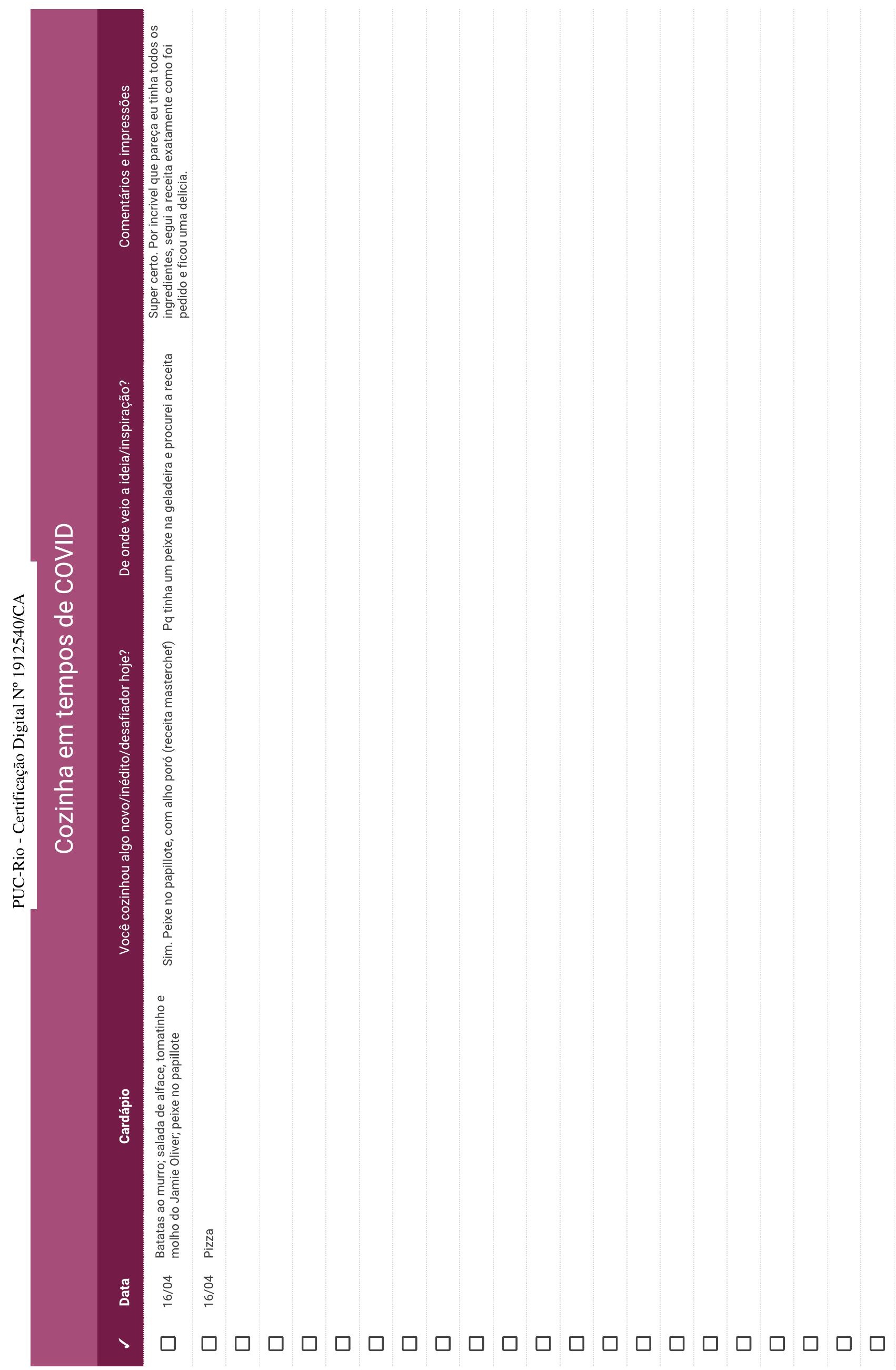




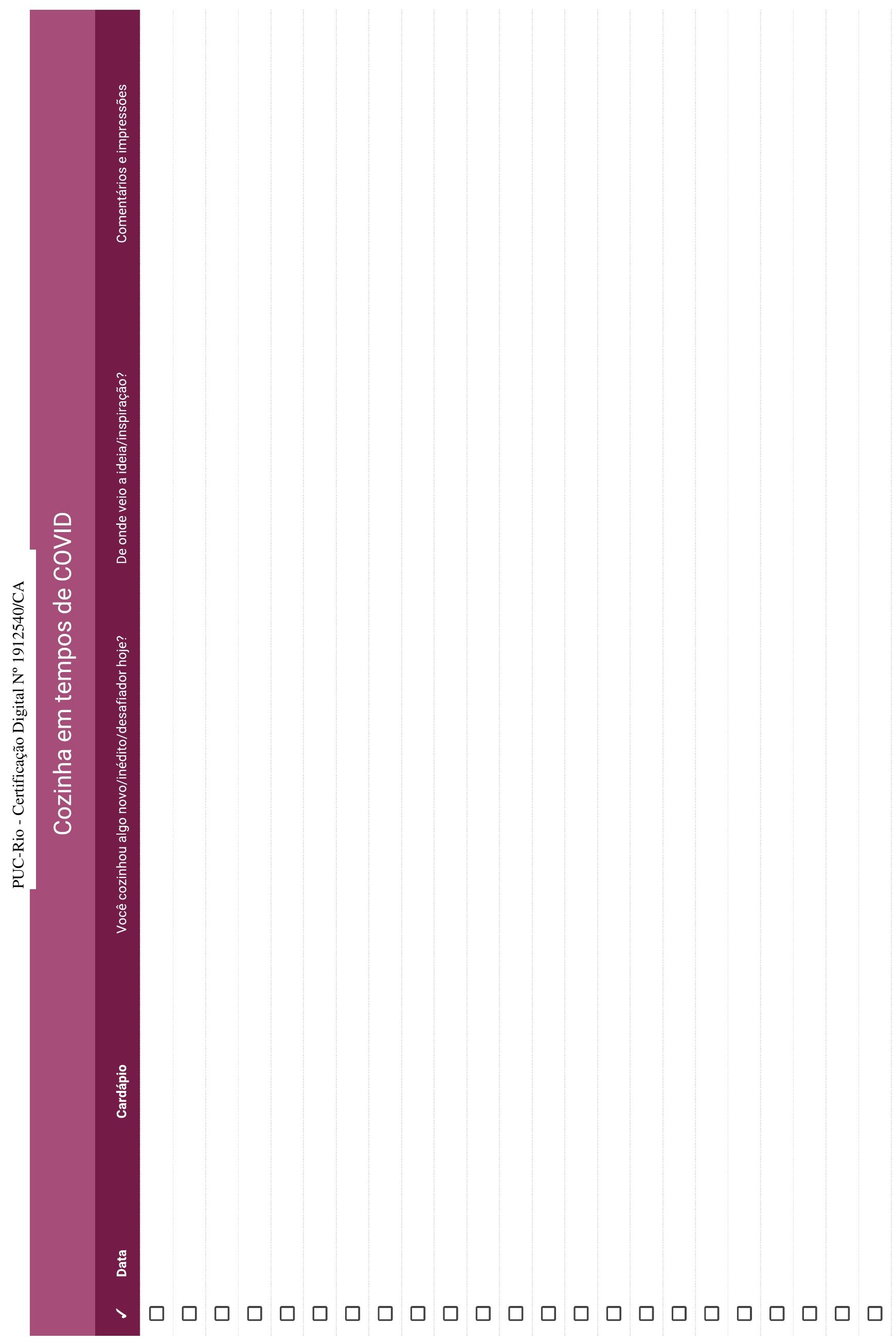




$$
\text { | }
$$




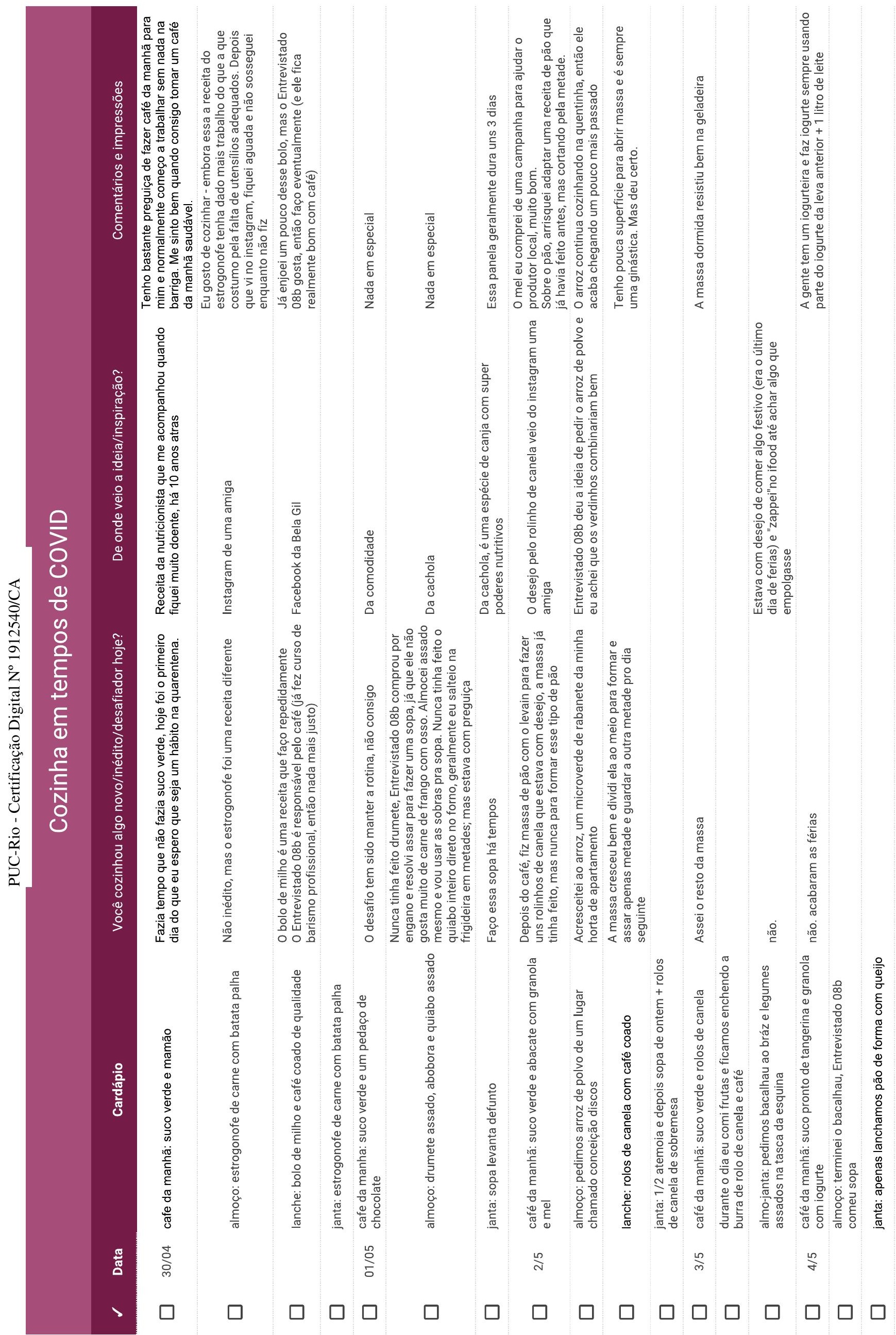




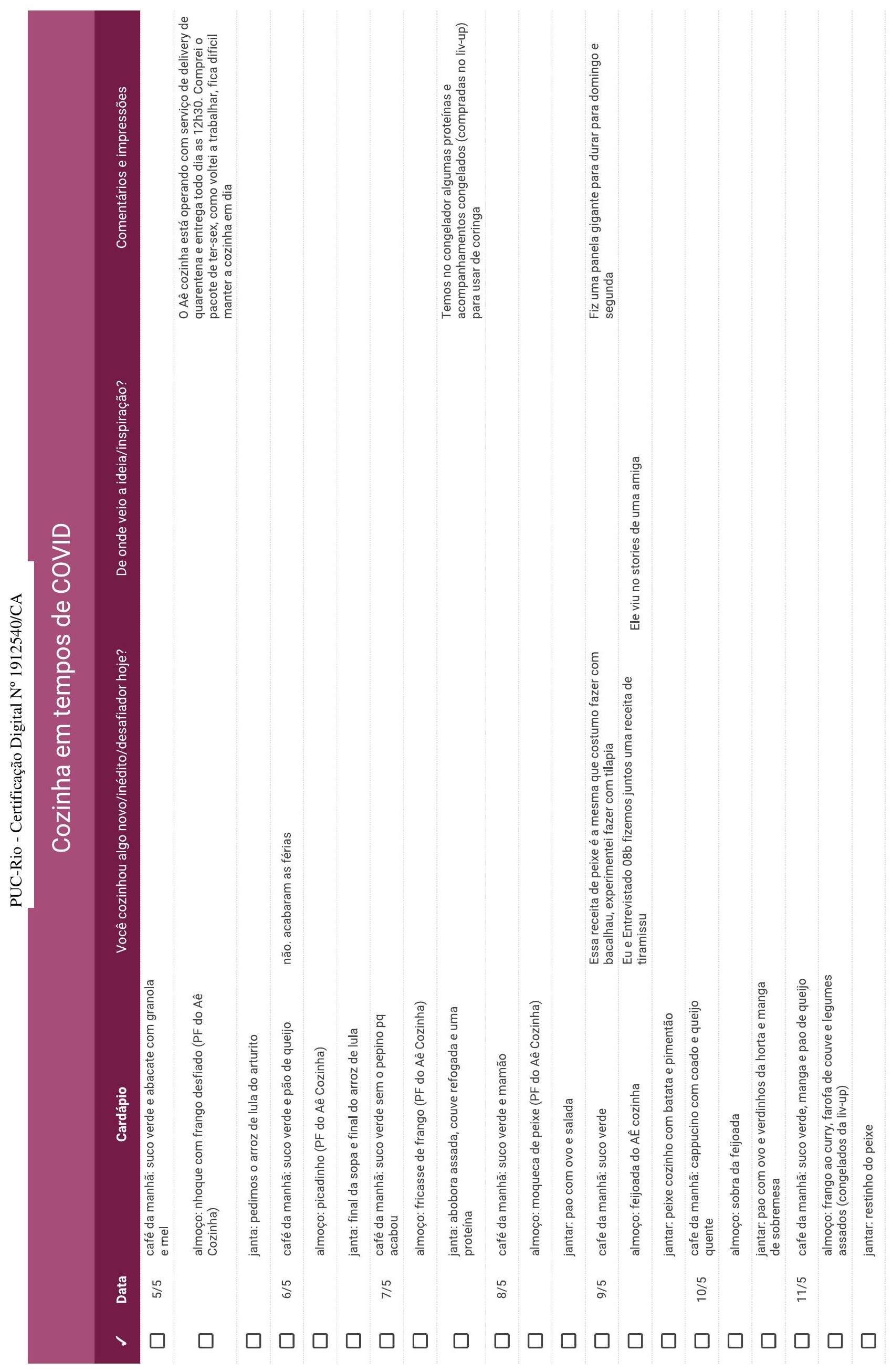





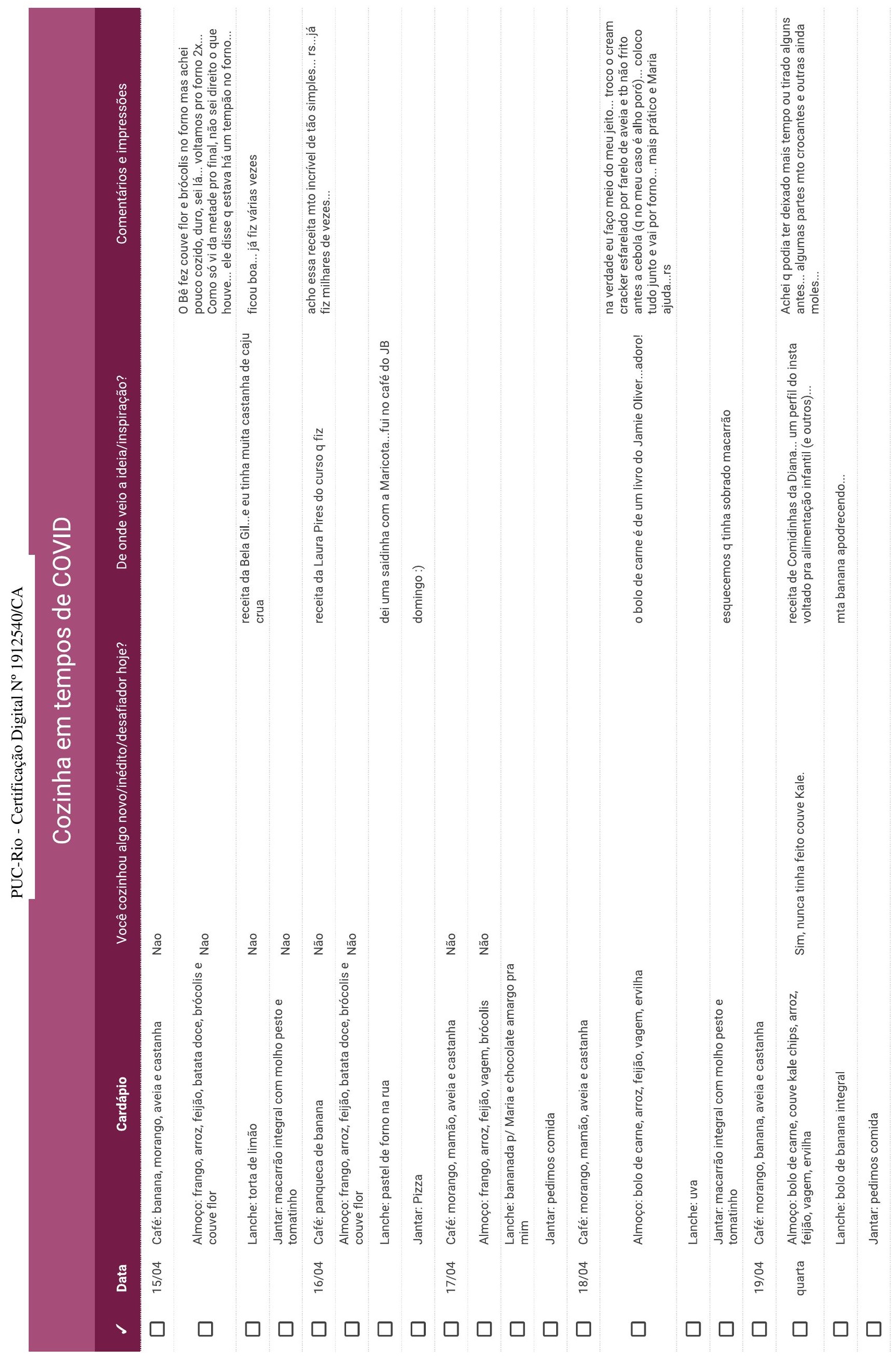




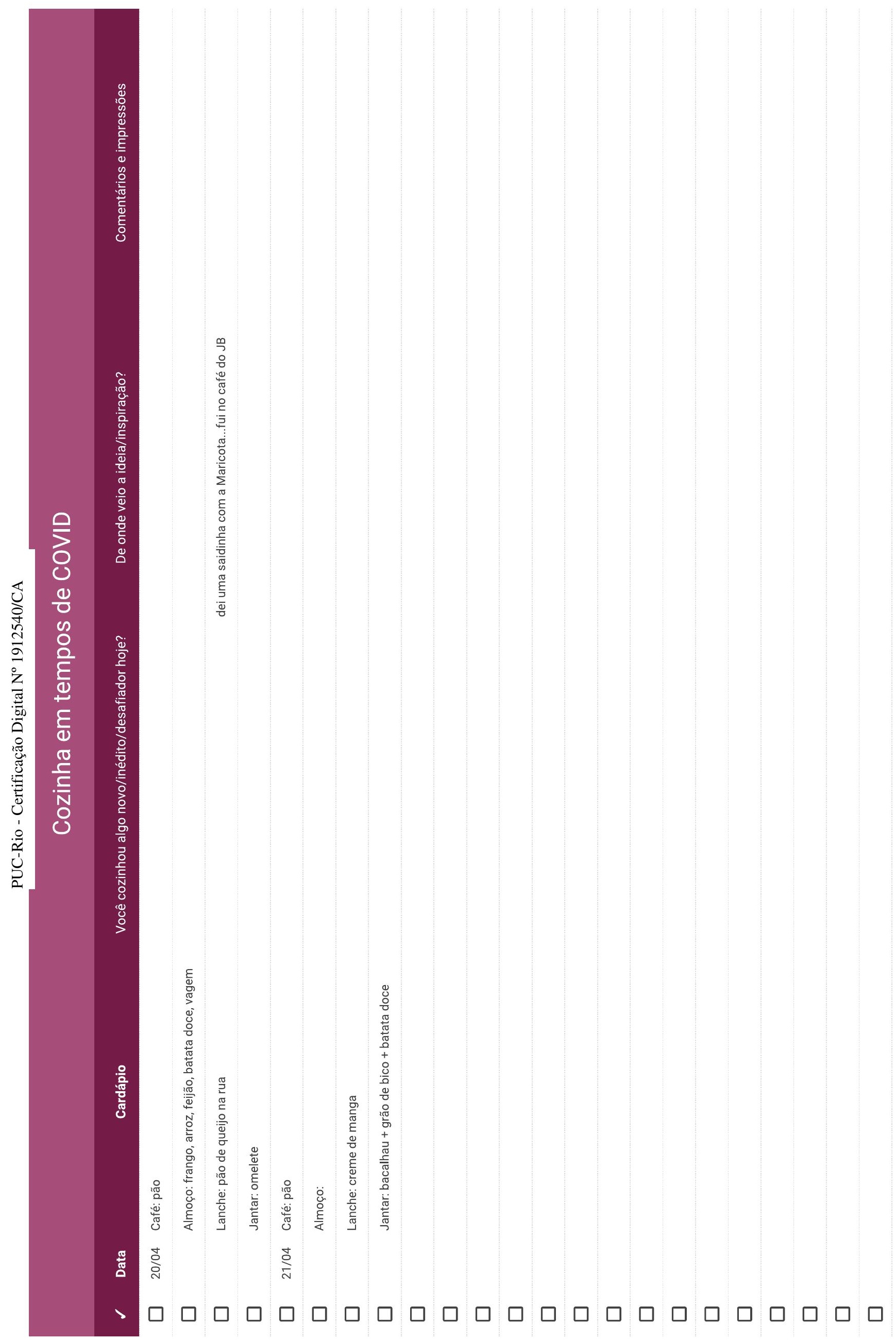




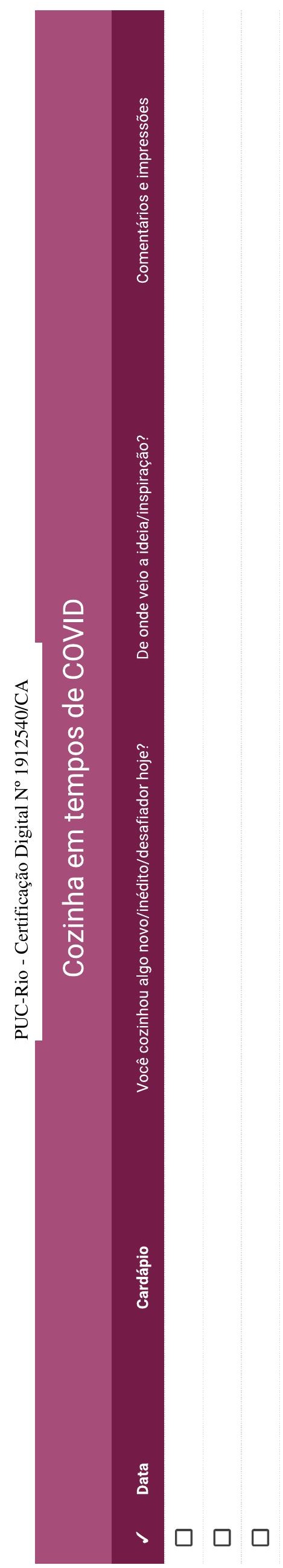




\section{Cartões de Insight}
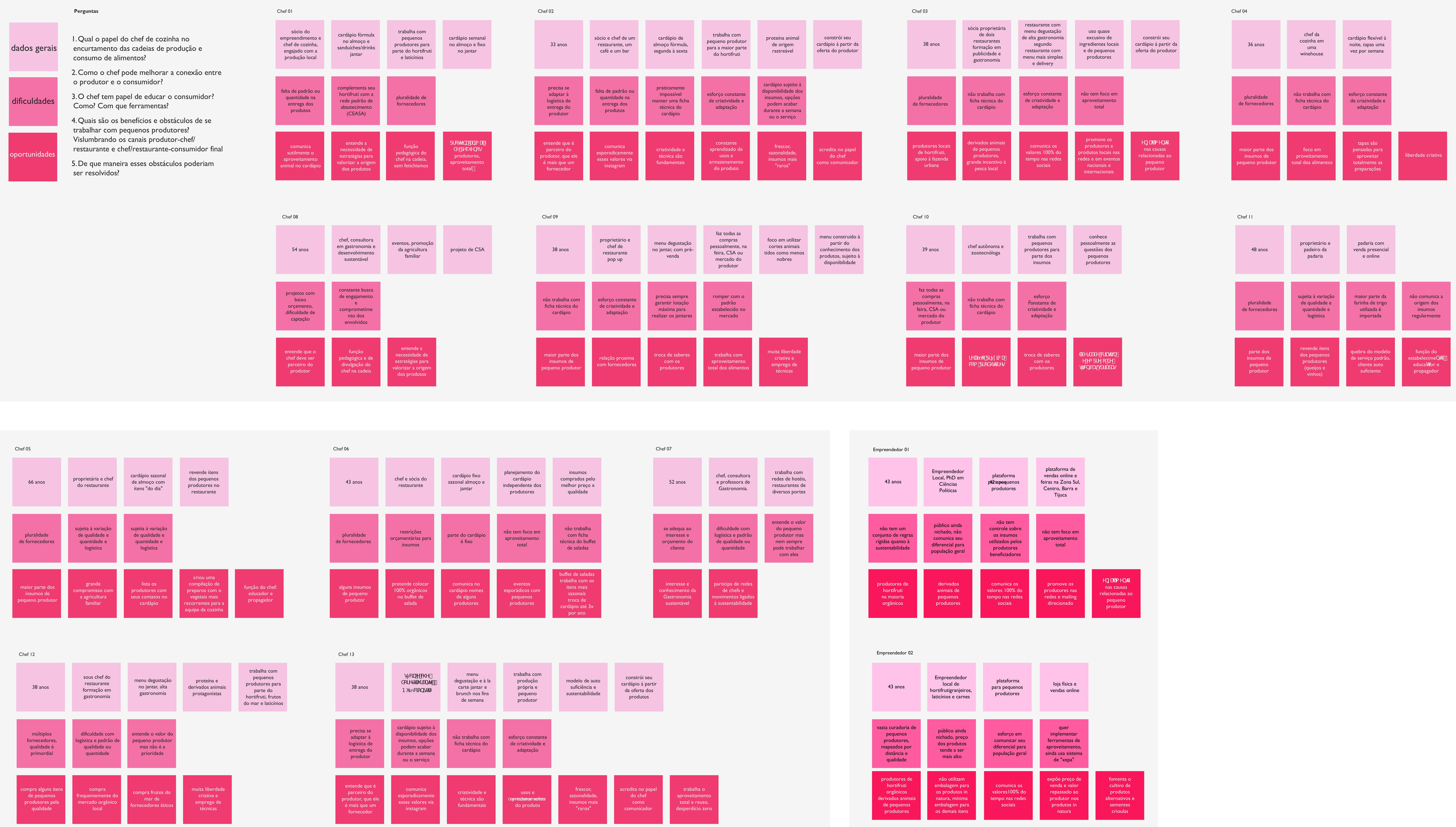


\section{Cartões de Insight}

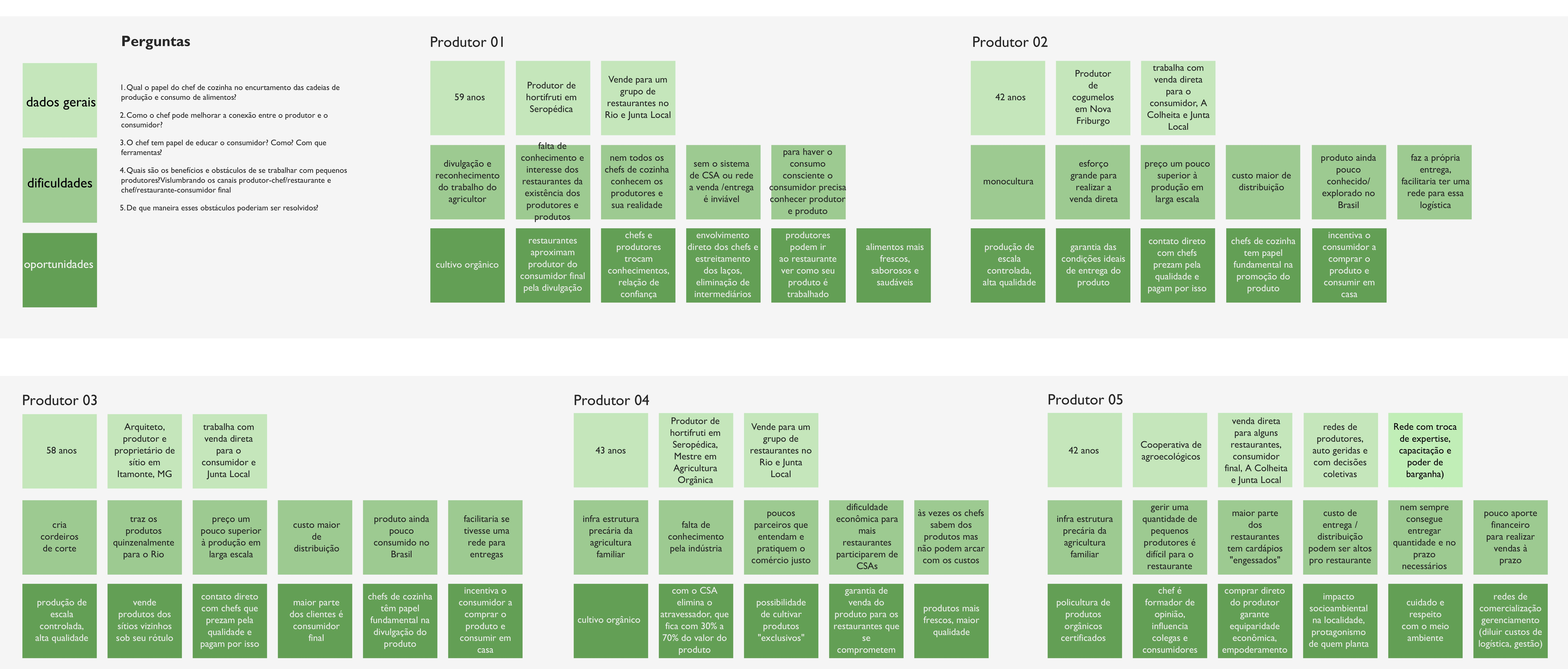


Junta Local Quem Somos Sacola Virtual ${ }^{1}$ Feiras Quem Faz Dúvidas

Revista

\section{Carta de Valores e Princípios}

\section{Rede da Junta}

A Junta Local se baseia na sinergia entre todos os envolvidos e na identificação de todos com compromissos coletivos e valores compartilhados.

O entendimento da Junta como um coletivo diverso - enraizado nas noções de coresponsabilidade, engajamento, pertencimento e diálogo - é a base de nossa inteligência coletiva, que se constrói continuamente em todas as nossas esferas de contato: feiras, boletins, assembleias, reuniões, encontros.

O prazer de estar JUNTO e remando numa mesma direção é o que nos faz acreditar que "o cr-cimento de um é o crescimento de todos".

仓্র

\section{Zastreabilidade e Localidade}

$A^{\prime Z}$ 'oximidade é o que viabiliza nossa existência enquanto local de aproximação e encontro entre p.

苗

A

a U己

tí.@o para a seleção de matéria-prima, quanto para a definição de processos produtivos.

它

N. - unta, matérias-primas e produtos finais devem sempre dialogar com: contexto local e sazonal, boas práticas agrícolas e tradições gastronômicas locais.

\section{Amor pelo Produto e pelo Processo}

Os processos são tão importantes quanto o produtos, que são reflexos dos produtores. Por isso, a Junta caracteriza-se como um lugar de aprendizado e de troca. Nas feiras, "quem faz" marca presença, expressando todo o cuidado com seu produto e com seu público e participando de um constante intercâmbio de conhecimentos, que possibilita uma contínua evolução no seu fazer artesanal.

Se nutrimos tanto amor pelo que fazemos, conhecer "pra quem" produzimos é fundamental.

\section{Sustentabilidade e Tempo}

Faz parte da nossa missão ter consciência sobre o impacto de nossos produtos e ações: impacto ambiental, social, econômico... De forma que a rastreabilidade integral de cada produto torna-se 
um princípio crucial.

É fundamental que pensemos na sustentabilidade de cada negócio em todas as suas esferas.

Nesta equação, devemos levar em conta o tempo do consumo de cada produto, assim como os processos produtivos mais adequados e viáveis.

Da mesma forma, a sustentabilidade da própria Junta deve ser encarada de forma responsável. Se queremos ser efetivamente uma alternativa ao sistema industrializado, temos que ter uma proposta econômica viável - coletiva e individualmente. E o preço a ser pago pelo consumidor deverá refletir este princípio e a estrutura enxuta que conseguimos construir, em coerência com nossos valores e objetivos.

\section{Transparência e Verdade}

$\mathrm{Na}$ Junta, além de alternativas à industrialização dos alimentos, também perseguimos formas alternativas de relação comercial, relações de trabalho mais humanas e, com isso, possibilitamos uma re-descoberta da venda direta.

Tornam-se valores essenciais e intrínsecos: a honestidade, a confiança e o respeito, que se refletem na qualidade dos encontros e na precificação justa e coerente.

\section{Eerramenta Política de Disseminação de Cultura}

$\wedge_{\check{Z}}^{\bar{a}}$ sa missão é ampla e educativa. É necessário criar, expandir e democratizar a cultura do "bom, lc. têิ ram uma subsistência digna, ao mesmo tempo em que mais pessoas têm acesso a esses

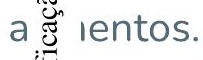

$\Lambda$ U te sentido, precisamos também conscientizar o público a respeito dos processos naturais, re⿻

定

É fundamental que o produtor seja um agente de informação e sensibilização, em relação à sazonalidade e ao resgate das origens.

Somos também promotores de impacto urbano, ocupando espaços públicos, recuperando o potencial cultural das ruas e melhorando a qualidade de vida em nossa cidade.

Carta elaborada por GT-ética, a partir dos resultados do Forum com Ajuntados. 
Página Inicial

Sobre a Junta

Feiras

Sacola Virtual

Quem Faz

Revista

Carta de Valores e Princípios

Dúvidas e Contato

Termos de Uso

Política de Privacidade

\section{Receba nossas novidades}

seu nome

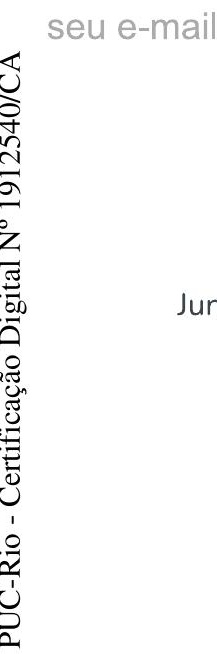

enviar

Junta Local Produções Ltda. CNPJ:22.030.566/0001-07 / Rio De Janeiro, RJ / contato@juntalocal.com 
Sessões Generativas • painel de especialistas

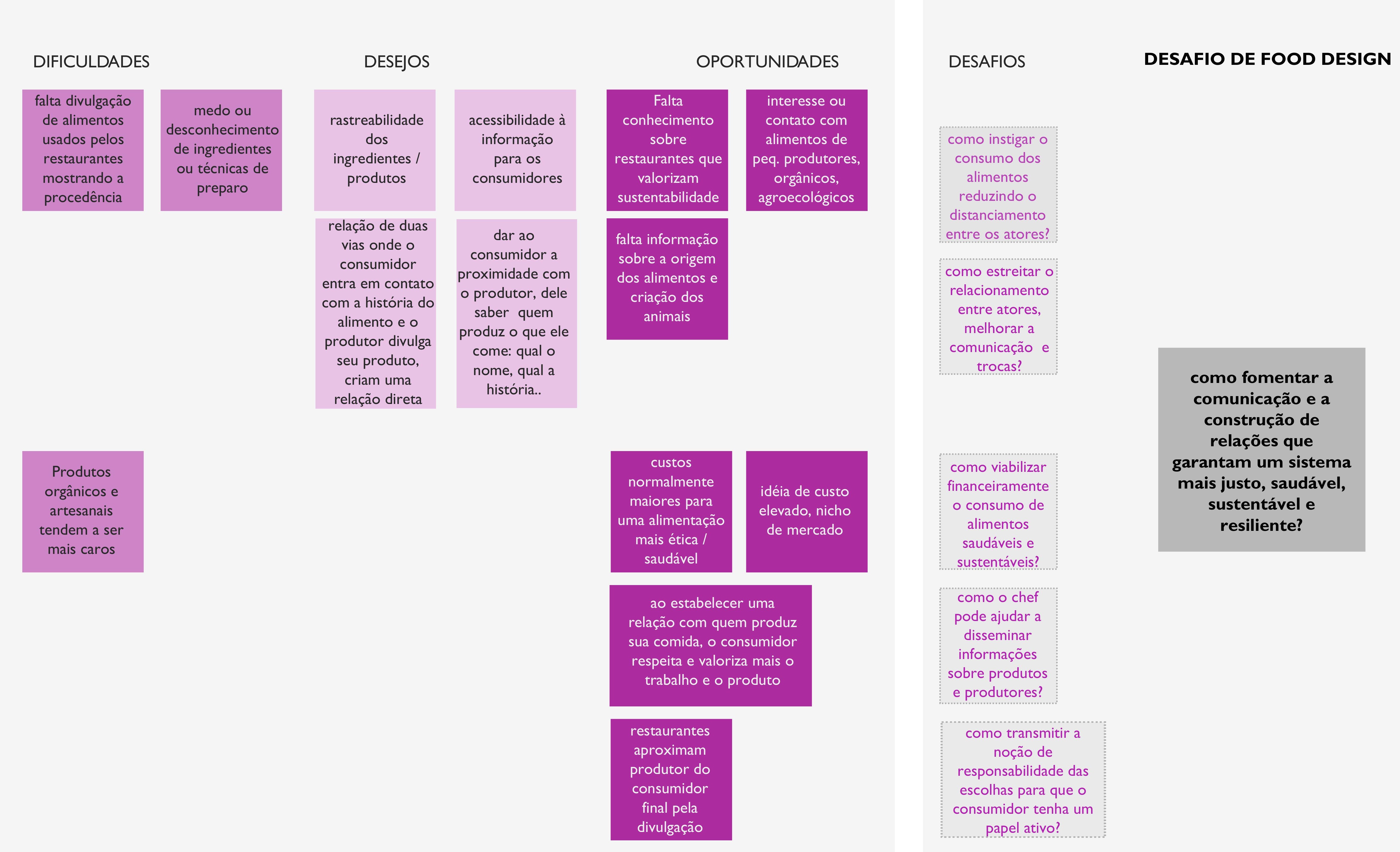


Sessões Generativas . painel de especialistas

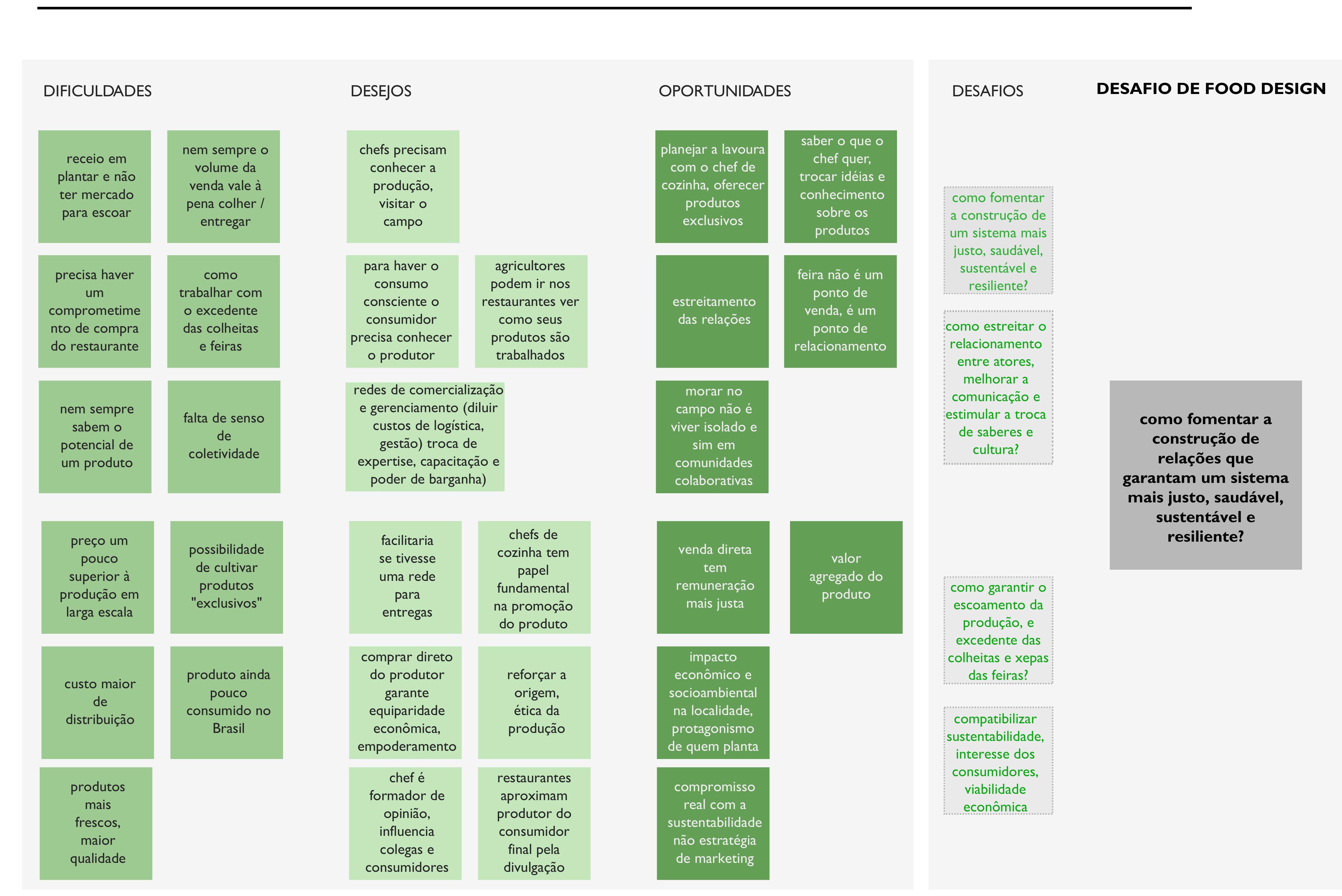


Sessões Generativas • painel de especialistas

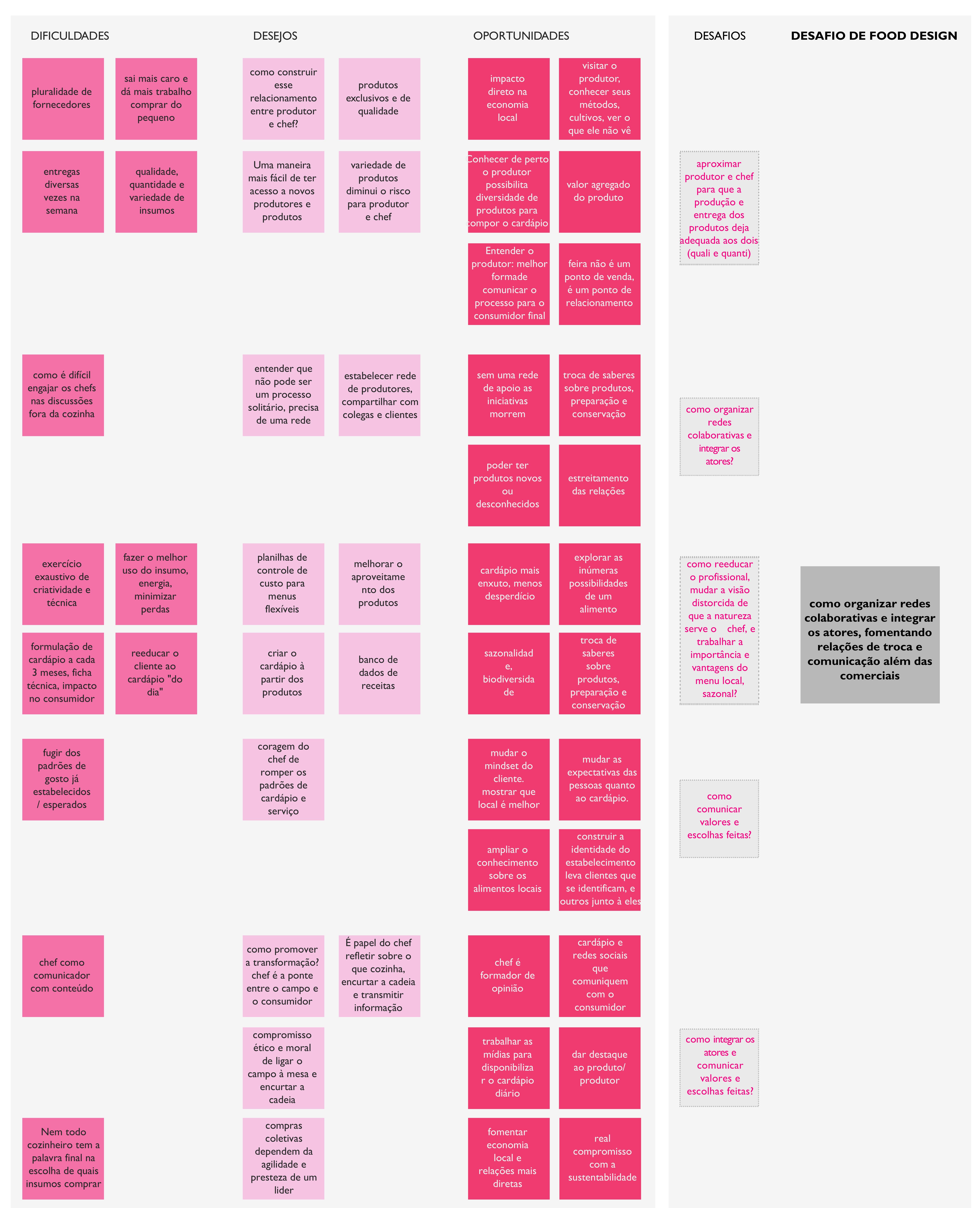




\section{Planta}

jornada do serviço produtor . chef . consumidor

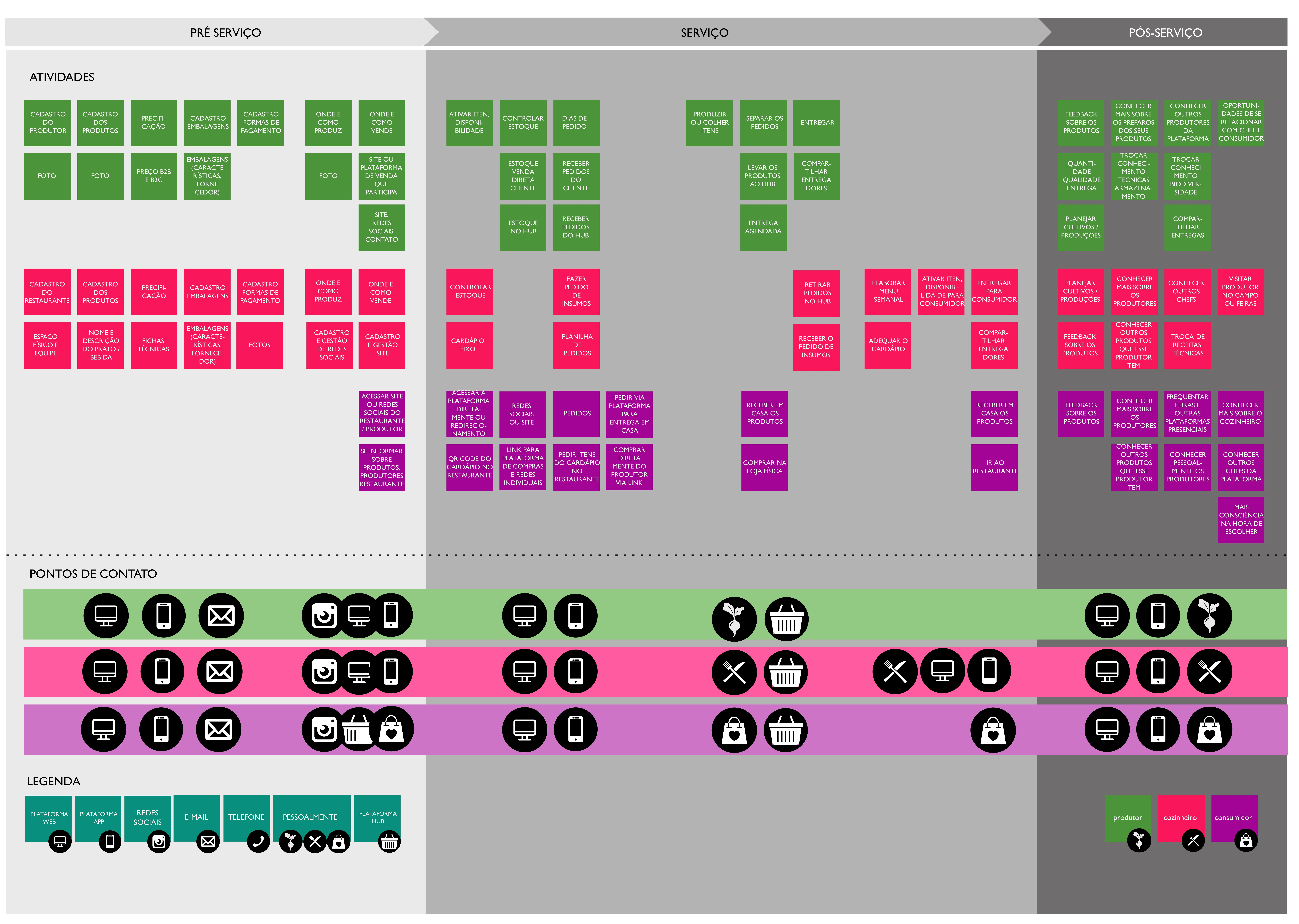

